\title{
Phanerozoic Tectonic Evolution of the Circum-North Pacific
}

\section{Professional Paper 1626}

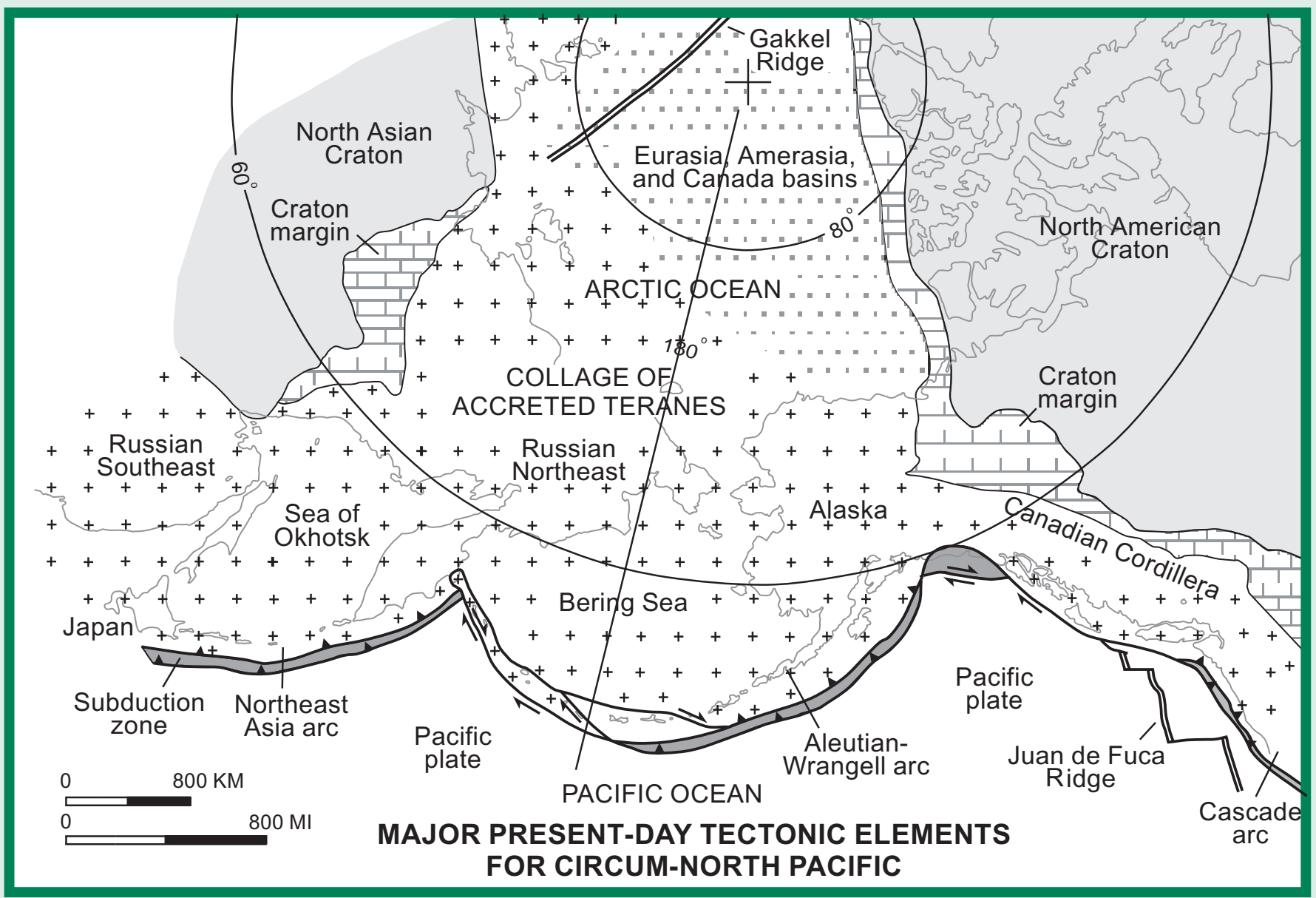

\section{U.S. Department of the Interior}

U.S. Geological Survey 


\section{Availability of Publications of the U.S. Geological Survey}

Order U.S. Geological Survey (USGS) publications from the offices listed below. Detailed ordering instructions, along with prices of the last offerings, are given in the current-year issues of the catalog "New Publications of the U.S. Geological Survey."

\section{Books, Maps, and Other Publications}

\section{By Mail}

Books, maps, and other publications are available by mail from-

\section{USGS Information Services}

Box 25286, Federal Center

Denver, CO 80225

Publications include Professional Papers, Bulletins, WaterSupply Papers, Techniques of Water-Resources Investigations, Circulars, Fact Sheets, publications of general interest, single copies of permanent USGS catalogs, and topographic and thematic maps.

\section{Over the Counter}

Books, maps, and other publications of the U.S. Geological Survey are available over the counter at the following USGS Earth Science Information Centers (ESIC's), all of which are authorized agents of the Superintendent of Documents:

- Anchorage, Alaska-Rm. 101, 4230 University Dr.

- Denver, Colorado-Bldg. 810, Federal Center

- Menlo Park, California-Rm. 3128, Bldg. 3, 345 Middlefield Rd.

- Reston, Virginia-Rm. 1C402, USGS National Center, 12201 Sunrise Valley Dr.

- Salt Lake City, Utah-2222 West, 2300 South (books and maps available for inspection only)

- Spokane, Washington-Rm. 135, U.S. Post Office Building, 904 West Riverside Ave.

- Washington, D.C.-Rm. 2650, Main Interior Bldg., 18th and C Sts., NW.

Maps only may be purchased over the counter at the following USGS office:

- Rolla, Missouri-1400 Independence Rd.

\section{Electronically}

Some USGS publications, including the catalog "New Publications of the U.S. Geological Survey" are also available electronically on the USGS's World Wide Web home page at http://www.usgs.gov

\section{Preliminary Determination of Epicenters}

Subscriptions to the periodical "Preliminary Determination of Epicenters" can be obtained only from the Superintendent of
Documents. Check or money order must be payable to the Superintendent of Documents. Order by mail from-

Superintendent of Documents Government Printing Office Washington, DC 20402

\section{Information Periodicals}

Many Information Periodicals products are available through the systems or formats listed below:

\section{Printed Products}

Printed copies of the Minerals Yearbook and the Mineral Commodity Summaries can be ordered from the Superintendent of Documents, Government Printing Office (address above). Printed copies of Metal Industry Indicators and Mineral Industry Surveys can be ordered from the Center for Disease Control and Prevention, National Institute for Occupational Safety and Health, Pittsburgh Research Center, P.O. Box 18070, Pittsburgh, PA 15236-0070.

\section{Mines FaxBack: Return fax service}

1. Use the touch-tone handset attached to your fax machine's telephone jack. (ISDN [digital] telephones cannot be used with fax machines.)

2. Dial (703) 648-4999.

3. Listen to the menu options and punch in the number of your selection, using the touch-tone telephone.

4. After completing your selection, press the start button on your fax machine.

\section{CD-ROM}

A disc containing chapters of the Minerals Yearbook (199395), the Mineral Commodity Summaries (1995-97), a statistical compendium (1970-90), and other publications is updated three times a year and sold by the Superintendent of Documents, Government Printing Office (address above).

\section{World Wide Web}

Minerals information is available electronically at http://minerals.er.usgs.gov/minerals/

\section{Subscription to the catalog "New Publications of the U.S. Geological Survey"}

Those wishing to be placed on a free subscription list for the catalog "New Publications of the U.S. Geological Survey" should write to-

U.S. Geological Survey

903 National Center

Reston, VA 20192 


\section{Phanerozoic Tectonic Evolution of the Circum-North Pacific}

By Warren J. Nokleberg, Leonid M. Parfenov, James W. H. Monger, lan 0. Norton, Alexander I. Khanchuk, David B. Stone, Christopher R. Scotese, David W. Scholl, and Kazuya Fujita

Professional Paper 1626

Prepared in cooperation with Exxon Exploration Co.

Geological Survey of Canada

Michigan State University

Russian Academy of Sciences

University of Alaska

University of Texas

Yakutian Academy of Sciences 


\title{
U.S. Department of the Interior \\ Gale A. Norton, Secretary
}

\section{U.S. Geological Survey \\ Charles G. Groat, Director}

\begin{abstract}
Any use of trade, product, or firm names in this publication is for descriptive purposes only and does not imply endorsement by the U.S. Government.
\end{abstract}

United States Government Printing Office: 2000

For additional copies please contact:

USGS Information Services

Box 25286

Denver, CO 80225

This report and any updates to it are available online at http://geopubs.wr.usgs.gov/prof-paper/pp1626/

Additional USGS publications can be found online at tttp://geology.usgs.gov/products.html

For more information about the USGS and its products:

Telephone: 1-888-ASK-USGS

World Wide Web: http://www.usgs.gov/

Text edited by George A. Havach

Layout and design by Stephen L. Scott

Manuscript approved for publication, November 8, 1999

Library of Congress Cataloging-in-Publication Data

Phanerozoic tectonic evolution of the Circum-North Pacific / by Warren J. Nokleberg...

[et al.].

p. cm. -- (Professional paper ; 1626)

Includes bibliographical references.

1. Geology, Structural--Pacific Coast (North America) 2. Geology, Structural--Pacific Coast (Asia) I. Nokleberg, Warren J. II. U.S. Geological Survey professional paper ; 1626.

QE626 .P52 2001

$551.8^{\prime} 09182^{\prime} 3--d c 2$

2001018994

FRONT COVER

Major present-day tectonic elements of the Circum-North Pacific and names of major geographic regions. Major tectonic events: (1) continuation of a series of continental-margin arcs and companion subduction-zone assemblages around the Circum-North Pacific; (2) continuation of opening of major sedimentary basins behind major arcs; (3) in eastern part of the Circum-North Pacific, a continuation of dextral transpression between the Pacific oceanic plate and the present-day Canadian Cordillera margin; and (4) continuation of sea-floor spreading in the Arctic and eastern Pacific 0ceans. See figure 7 for explanation of abbreviations, symbols, and patterns. 


\section{CONTENTS}

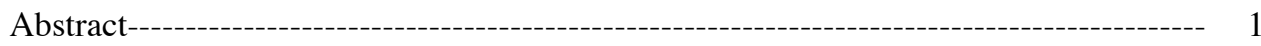

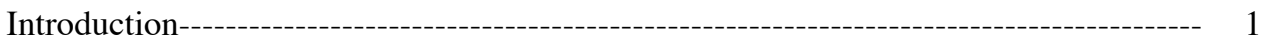

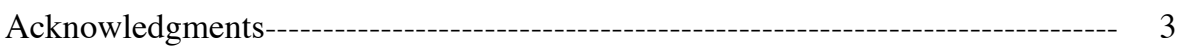

Associated Studies------------ 3

Key Terms for Tectonic Analysis of the Circum-North Pacific------------------ 4

Method of Tectonic Analysis--------------------------------------- 4

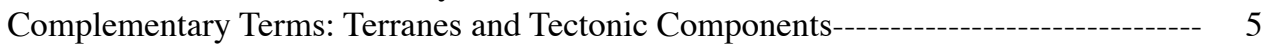

Analysis of Terranes--------------------------------------------- 5

Analysis of Components of Tectonic Collages----------------------------- 5

Methods for Correlation, Linkage, and Alignment of Major Terranes and Overlap

Assemblages-------- 5

Correlation of Terranes and Overlap Assemblages------------------------------ 6

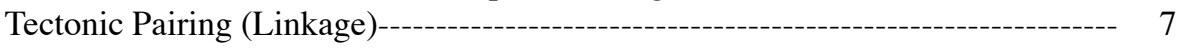

Alignment of Coeval Arcs and Subduction Zones---ons 7

Problems of Correlations, Tectonic Linkages, and Alignments-------------- 8

Descriptions of Geology, Correlations, and Linkages of Major Terranes and Overlap

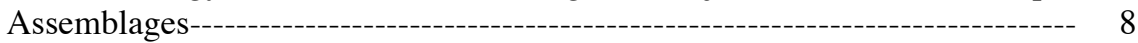

Cratons, Cratonal Terranes, Passive Continental Margins, and Passive-

Continental-Margin Terranes--------------------------------------- 9

Continental-Margin and Cratonal Terranes in the Russian Southeast--------------- 9

Origin of the Khanka Continental-Margin-Arc Superterrane and the Laoelin-Grodekorsk Island-Arc Terrane----------------------

Origin of the Argun, Baladek, and Gonzha Cratonal Terranes, the Ayansk and Oldoi Passive-Continental-Margin Terranes, and the Mamyn and Bureya Continental-Margin-Arc Terranes-

Correlation of Passive-Continental-Margin Terranes in the Russian Northeast, Alaska, and the Canadian Cordillera and Linkage to the North American Craton----------- 14

Eastern Part of the Chukotka Terrane and the Arctic Alaska Superterrane-- 14 Cassiar Terrane-------o- 14

Correlation of Metamorphosed Continental-Margin Terranes in the Russian Northeast, Alaska, and the Canadian Cordillera and Linkage to the North American Craton-

Correlation of Part of the Taymyr Peninsular Collage with the Verkhoyansk Fold-and-Thrust Belt (North Asian Cratonal Margin)----------------------

Correlation of Passive-Continental-Margin Terranes in the Russian Northeast with the Verkhoyansk Fold-and-Thrust Belt----------------------------- 15

Derivation of Passive-Continental-Margin Terranes in West-Central Alaska from the Verkhoyansk Fold-and-Thrust Belt in the Russian Northeast---------- 16

Origin of the Nixon Fork, Dillinger, and Mystic Terranes----------------- 17

Derivation of the Kilbuck-Idono Cratonal Terrane from the North Asian Craton

Derivation of the Okhotsk and Omolon Cratonal Terranes from Devonian and Older Parts of the North Asian Craton----------------------------- 17

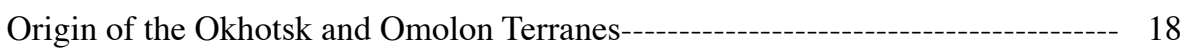

Correlation, Linkage, and Alignment of Late Paleozoic Through Mid-

Cretaceous Island-Arc Terranes of the Wrangellia Superterrane--------------- 18

Sequences of the Wrangellia Superterrane------------------------------- 18

Stratigraphic Succession of Late Paleozoic and Mesozoic Arcs of the Wrangellia Superterrane------------------------------------- 18

Correlation, Linkage, and Alignment of Triassic Through Mid-Cretaceous Continental-Margin Arcs, Island Arcs, and Tectonically Paired Subduction Zones- 


\section{CONTENTS}

Descriptions of Geology, Correlations, and Linkages of Major Terranes and Overlap Assemblages-Continued

Correlation, Linkage, and Alignment of Triassic Through Mid-Cretaceous

Middle and Late Jurassic Monakin Arc in the Russian Southeast-------------- 19

Subduction-Zone Terranes in the Russian Southeast and on Hokkaido Island

Tectonically Linked to the Jurassic Monakin Arc and Correlative Igneous

Arcs in Korea and China-------- 19

Jurassic and Early Cretaceous Umlekan Arc in the Russian Southeast------------ 20

Igneous- and Sedimentary-Rock Units of the Umlekan Arc---------------- 20

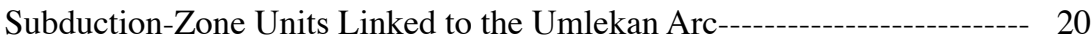

Origin of the Umlekan Arc-----o- 21

Early and Mid-Cretaceous Khingan Arc in the Russian Southeast--------------- 21

Origin of the Khingan Arc---------on 21

Mid-Cretaceous Kema Island Arc in the Eastern Part of the Russian Southeast--- 22

Rock Units of the Kema Arc---

Subduction-Zone Units Related to the Kema Arc-------------- 22

Origin of the Kema Arc---

Late Jurassic and Early Cretaceous Uda Arc in the Central Part of the Russian

Far East------------------------------------- 22

Rock Units of the Uda Arc---

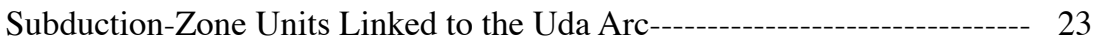

Origin of the Uda Arc--------- 23

Late Triassic to Early Cretaceous Kony-Murgal Arc in the Russian Northeast---- 23

Subduction-Zone Units Linked to the Kony-Murgal Arc------------------ 24

Origin of the Kony-Murgal Arc-------------------------------- 24

Late Jurassic Through Mid-Cretaceous Pekul'ney Arc in the Russian Northeast--- 24

Subduction-Zone Units Linked to the Pekul'ney Arc------------------ 24

Origin of the Pekul'ney Arc------------------------------------- 24

Late Jurassic Through Mid-Cretaceous Mainitskiy Arc in the Russian Northeast--- 25

Subduction-Zone Units Linked to the Mainitskiy Arc------------------ 25

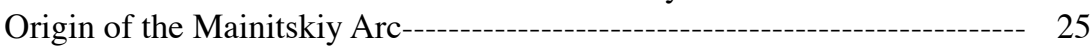

Late Jurassic and Early Cretaceous Uyandina Arc in Russian Northeast----------- 25

Rock Units of the Uyandina Arc------------- 25

Subduction-Zone Units Linked to the Uyandina Arc----------------------- 26

Origin of the Uyandina Arc---------- 26

Late Jurassic and Early Cretaceous Oloy and Svyatov Nos Arcs in the Russian Northeast-------------- 26

Subduction-Zone Units Linked to the Svyatov Nos and Oloy Arcs---------- 26

Origin of the Oloy and Svyatov Nos Arcs------------------------------ 27

Late Paleozoic to Early Jurassic Alazeya Island Arc in the Russian Northeast---- 27

Rock Units of the Alazeya Arc------------------------------------ 27

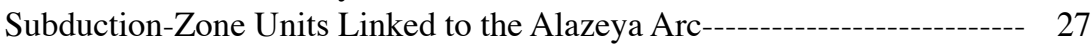

Origin of the Alazeya Arc--- 27

Late Jurassic Through Mid-Cretaceous Nutesyn-Koyukuk Arc in the Russian Northeast and Western Alaska-------- 27

Rock Units of the Nutesyn-Koyukuk Arc---_-

Subduction-Zone Units Linked to the Nutesyn-Koyukuk Arc--------------- 28

Origin of the Nutesyn-Koyukuk Arc----------------------------- 29

Late Jurassic Through Mid-Cretaceous Gravina Arc in Southern Alaska and the Canadian Cordillera---------------------------------------------- 29

Rock Units of the Gravina Arc---- 29

Subduction-Zone Units Linked to the Gravina Arc------------------------ 30

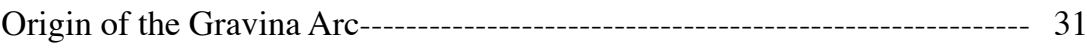

Late Triassic and Early Jurassic Talkeetna-Bonanza Arc in Alaska and the

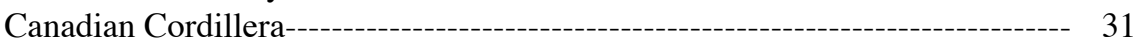




\section{CONTENTS}

Descriptions of Geology, Correlations, and Linkages of Major Terranes and Overlap

Assemblages-Continued

Late Triassic and Early Jurassic Talkeetna-Bonanza Arc in Alaska and the Canadian Cordillera-Continued

Rock Units of the Late Triassic and Early Jurassic Talkeetna-Bonanza

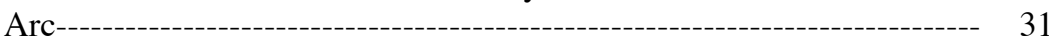

Subduction-Zone Units Linked to the Talkeetna-Bonanza Arc---------- 32

Backarc Sequences Linked to the Talkeetna-Bonanza Arc----------------- 32

Origin of the Talkeetna-Bonanza Arc---

Late Triassic and Early Jurassic Stikinia-Quesnellia Island Arc in East-Central Alaska and the Canadian Cordillera---------------------- 32

Rock Units of the Stikinia-Quesnellia Arc---------------------------- 32

Subduction-Zone Units Linked to the Stikinia-Quesnellia Arc------------ 33

Origin of the Stikinia-Quesnellia Arc--------------------------- 34

Correlation, Linkage, and Alignment of Late Cretaceous and Early Cenozoic

Continental-Margin Arcs, Island Arcs, and Tectonically Paired Subduction

Zones-

Cretaceous and Early Tertiary East Sikhote-Alin Arc in the Russian Southeast--- 34

Rock Units of the East Sikhote-Alin Arc---

Subduction-Zone Units Linked to the East Sikhote-Alin Arc--------------- 34

Origin of the East Sikhote-Alin Arc---- 35

Cretaceous and Early Tertiary Okhotsk-Chukotka Arc in the Russian Northeast- 35

Rock Units of the Okhotsk-Chukotka Arc----

Subduction-Zone Units Linked to the Okhotsk-Chukotka Arc------------ 36

Origin of the Okhotsk-Chukotka Arc---

Late Cretaceous and Early Tertiary Olyutorka Arc in the Russian Far East------- 36

Rock Units of the Olyutorka Arc------------------ 37

Subduction-Zone Units Linked to the Olyutorka Arc--------------------- 37

Origin of the Olyutorka Arc---------on 37

Late Cretaceous and Early Tertiary Kluane and Coast Arcs in Southern Alaska and the Canadian Cordillera------------ 38

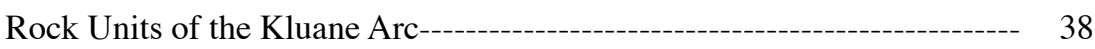

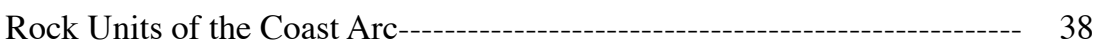

Subduction-Zone Units Linked to the Kluane and Coast Arcs------------ 38

Origin of the Kluane and Coast Arcs---_on

Correlation, Linkage, and Alignment of Middle and Late Cenozoic Continental-Margin Arcs and Tectonically Paired Subduction Zones--- 39

Northeast Asia Arc---_or 39

Rock Units of the Northeast Asia Arc--------- 39

Subduction-Zone Units Linked to the Northeast Asia Arc----_-_-------- 40

Backarc Units Linked to the Northeast Asia Arc---_-

Origin of the Northeast Asia Arc-----

Aleutian-Wrangell Arc in Southern Alaska-----o---o 41

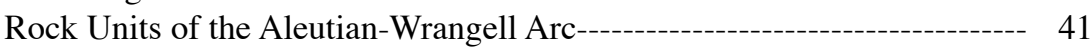

Subduction-Zone Units Linked to the Aleutian-Wrangell Arc------------- 42

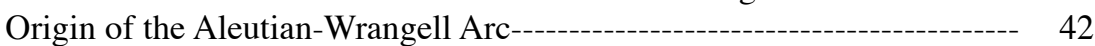

Cascade Arc in the Southern Part of the Canadian Cordillera and the U.S. Pacific Northwest

Subduction-Zone and Backarc Units Linked to the Cascade Arc------------ 42

Origin of the Cascade Arc--- 43

Linkages Between Belts of Anatectically Related (Collisional) Igneous Rocks and Accretions of Terranes---------- 43

Linkage of the Verkhoyansk Plutonic Belt with Accretion of the KolymaOmolon Superterrane to the North Asian Cratonal Margin ------- 43 Characteristics of the Verkhoyansk Collisional Granite Belt---------- 43

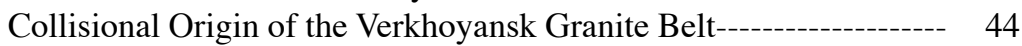




\section{CONTENTS}

Descriptions of Geology, Correlations, and Linkages of Major Terranes and Overlap

Assemblages-Continued

Linkages Between Belts of Anatectically Related (Collisional) Igneous Rocks and Accretions of Terranes-Continued

Linkage of the Omineca-Selwyn Plutonic Belt to Mid-Cretaceous

Accretion of Outboard Terranes Along the North American

Continental Margin

Characteristics of the Omineca-Selwyn Plutonic Belt-----------------

Collisional Origin of the Omineca-Selwyn Plutonic Belt-------------

Paleomagnetic Constraints

Paleomagnetic Constraints for Plate Reconstructions of Northeast Asia and

North America---------------------------------------- 45

Paleomagnetic Constraints for Terranes and Overlap Assemblages---------------- 45

Paleomagnetic-Variation Diagrams------------------------------------- 46

Kolyma-Omolon Superterrane------------------------------------- 46

Outboard Terranes in Russian Northeast----------------------------------- 47

Interior and Arctic Alaska--------------------------------------------- 47

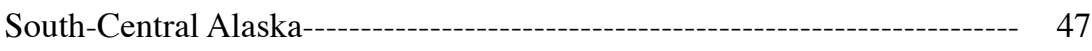

Southeastern Alaska and the Canadian Cordillera--------o------- 47

Paleomagnetic Dilemma: Loci of Accretion of the Wrangellia Superterrane----- 47

Phanerozoic Tectonic Model for the Circum-North Pacific----------------------------- 48

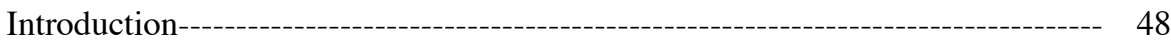

Mesozoic and Cenozoic Changes in Plate Motions------------------------- 51

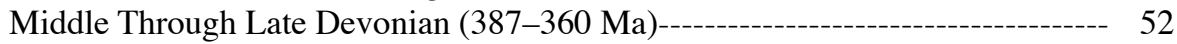

Specific Tectonic Events for the Middle Through Late Devonian---------- 52

Summary of Paleolatitude Data for the Middle Through Late Devonian--- 52

Mississippian (360-320 Ma)---------- 52

Specific Tectonic Events for the Mississippian------------------------- 53

Pennsylvanian (320-286 Ma)---------------------------------------- 53

Specific Tectonic Events for the Pennsylvanian------------------------ 53

Summary of Paleolatitude Data for the Mississippian, Pennsylvanian, and Permian--------------------------------------------------------- 58

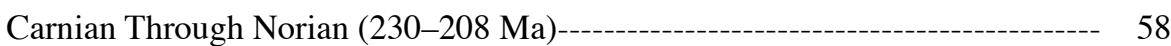

Specific Tectonic Events for the Carnian Through Norian---------------- 58

Summary of Paleolatitude Data for the Carnian Through Norian---------- 59

Hettangian Through Pleinsbachian (208-193 Ma)------------------------ 59

Specific Tectonic Events for the Hettangian Through Pleinsbachian------- 59

Summary of Paleolatitude Data for the Hettangian Through

Pleinsbachian------------------------------------------------------ 61

Toarcian Through Callovian (193-163 Ma)------------------------------ 63

Specific Tectonic Events for the Toarcian Through Callovian-------------- 63

Summary of Paleolatitude Data for the Toarcian Through Callovian------- 64

Oxfordian Through Kimmeridgian (163-144 Ma)------on 64

Specific Tectonic Events for the Oxfordian Through Kimmeridgian------- 65

Summary of Paleolatitude Data for the Oxfordian Through

Kimmeridgian--------- 66

Neocomian (144-120 Ma)----o- 67

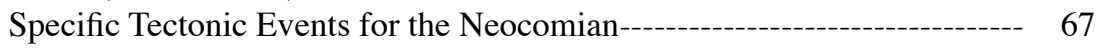

Summary of Paleolatitude Data for the Neocomian----------------------- 69

Aptian Through Albian (120-100 Ma)-------- 69

Specific Tectonic Events for the Aptian Through Albian--------------- 70

Summary of Paleolatitude Data for the Aptian Through Albian------------- 70

Cenomanian Through Santonian (100-84 Ma)------------------------- 70

Specific Tectonic Events for the Cenomanian Through Santonian--------- 71

Summary of Paleolatitude Data for the Cenomanian Through Santonian-- 73 


\section{CONTENTS}

Campanian Through Early Eocene (82-52 Ma)

Phanerozoic Tectonic Model for the Circum-North Pacific-Continued

Campanian Through Early Eocene (82-52 Ma) - Continued

Specific Tectonic Events for the Campanian Through Early Eocene------- 73

Summary of Paleolatitude Data for the Campanian Through Early

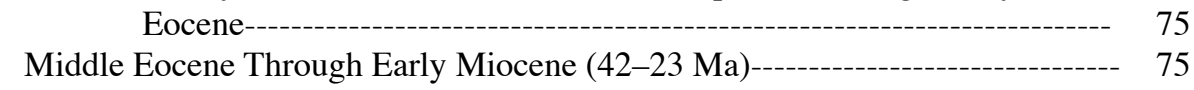

13

Specific Tectonic Events for the Middle Eocene Through Early Miocene- 76

Summary of Paleolatitude Data for the Middle Eocene Through Early

Miocene--------------------------------------------------- 77

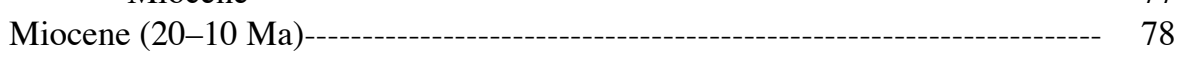

Specific Tectonic Events for the Miocene----on

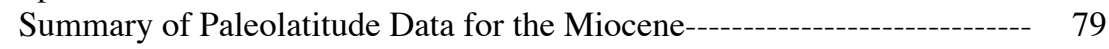

Pliocene Through the Present (4-0 Ma)--- 79

$\begin{array}{ll}\text { Specific Tectonic Events for the Middle Pliocene Through Present------- } & 80 \\ - & 81\end{array}$

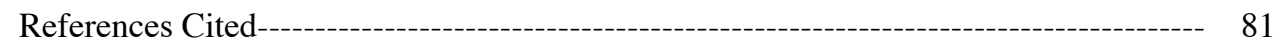

\section{FIGURES}

1. Generalized terrane map of the Russian Far East, northern Japan, and adjacent offshore areas------------------------- 6

2. Generalized terrane map of Alaska, the Canadian Cordillera, and adjacent offshore areas------------- 8

3. Generalized map of overlap assemblages and tectonically linked subduction-zone terranes in the Russian Far East, northern Japan, and adjacent offshore areas---

4. Generalized map of overlap assemblages and tectonically linked subduction-zone terranes in Alaska, the Canadian Cordillera, and adjacent offshore areas-

5. Plots of paleolatitude versus time for terranes and overlap assemblages in the Russian

Far East, Alaska, and the Canadian Cordillera---------------- 48

6. Plots of paleolatitude versus time for the North Asian and North American Cratons-------------------- 50

7. Middle through Late Devonian (387-360 Ma) stage of tectonic model---o--on 54

8. Mississippian (360-320 Ma) stage of tectonic model---on- 56

9. Pennsylvanian (320-286 Ma) stage of tectonic model-- 57

10. Carnian through Norian (230-208 Ma) stage of tectonic model-- 60

11. Hettangian through Pliensbachian (208-163 Ma) stage of Tectonic model-- 62

12. Pliensbachian through Callovian (193-163 Ma) stage of tectonic model-- 64

13. Oxfordian through Kimmeridgian (163-144 Ma) stage of tectonic model-- 66

14. Neocomian (144-120 Ma) stage of tectonic model--- 68

15. Aptian through Albian (120-100 Ma) stage of tectonic model-- 69

16. Cenomanian through Santonian (100-84 Ma) stage of tectonic model-- 71

17. Campanian through Early Eocene (85-52 Ma) stage of tectonic model---a-- 74

18. Middle Eocene through Early Miocene (42-23 Ma) stage of tectonic model------------------------- 76

19. Miocene (20-10 Ma) (Fig. 14) stage of tectonic model--or-- 78

20. Pliocene through Present (4-0 Ma) stage of tectonic model-- 80

\section{TABLES}

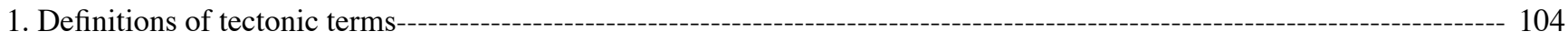

2. Summary of correlations and tectonic linkages for the Circum-North Pacific-------------- 106

3. Paleomagnetic data for geologic units and geographic areas in the Russian Far East, Alaska, and the Canadian

Cordillera- 


\title{
Phanerozoic Tectonic Evolution of the Circum-North Pacific
}

\author{
By Warren J. Nokleberg, ${ }^{1}$ Leonid M. Parfenov, ${ }^{2}$ James W.H. Monger, ${ }^{3}$ Ian 0. Norton, ${ }^{4}$ \\ Alexander I. Khanchuk, ${ }^{5}$ David B. Stone ${ }^{6}$ Christopher R. Scotese, ${ }^{7}$ David W. Scholl, ${ }^{1}$ \\ and Kazuya Fujita ${ }^{8}$
}

\section{Abstract}

The Phanerozoic tectonic evolution of the Circum-North Pacific is recorded mainly in the orogenic collages of the Circum-North Pacific mountain belts that separate the North Pacific from the eastern part of the North Asian Craton and the western part of the North American Craton. These collages consist of tectonostratigraphic terranes that are composed of fragments of igneous arcs, accretionary-wedge and subduction-zone complexes, passive continental margins, and cratons; they are overlapped by continental-margin-arc and sedimentary-basin assemblages. The geologic history of the terranes and overlap assemblages is highly complex because of postaccretionary dismemberment and translation during strike-slip faulting that occurred subparallel to continental margins. We analyze the complex tectonics of this region by the following steps. (1) We assign tectonic environments for the orogenic collages from regional compilation and synthesis of stratigraphic and faunal data. The types of tectonic environments include cratonal, passive continental margin, metamorphosed continental margin, continental-margin arc, island arc, oceanic crust, seamount, ophiolite, accretionary wedge, subduction zone, turbidite basin, and metamorphic. (2) We make correlations between terranes. (3) We group coeval terranes into a single tectonic origin, for example, a single island arc or subduction zone. (4) We group igneous-arc and subduction-zone terranes, which are interpreted as being tectonically linked, into coeval, curvilinear arc/subduction-zone complexes. (5) We interpret the original positions of terranes, using geologic, faunal, and paleomagnetic data. (6) We construct the paths of tectonic migration.

Six processes overlapping in time were responsible for most of the complexities of the collage of terranes and overlap assemblages around the Circum-North Pacific, as follows. (1) During the Late Proterozoic, Late Devonian, and Early

\footnotetext{
${ }^{1}$ U.S. Geological Survey.

${ }^{2}$ Yakutian Academy of Sciences.

${ }^{3}$ Geological Survey of Canada.

${ }^{4}$ Exxon Exploration Co.

${ }^{5}$ Russian Academy of Sciences.

6University of Alaska.

${ }^{7}$ University of Texas.

${ }^{8}$ Michigan State University.
}

Carboniferous, major periods of rifting occurred along the ancestral margins of present-day Northeast Asia and northwestern North America. The rifting resulted in the fragmentation of each continent and the formation of cratonal and passive-continental-margin terranes that eventually migrated and accreted to other sites along the evolving margins of the original or adjacent continents. (2) From about the Late Triassic through the mid-Cretaceous, a succession of island arcs and tectonically paired subduction zones formed near the continental margins. (3) From about mainly the midCretaceous through the present, a succession of igneous arcs and tectonically paired subduction zones formed along the continental margins. (4) From about the Jurassic to the present, oblique convergence and rotations caused orogenparallel sinistral and then dextral displacements within the upper-plate margins of cratons that have become Northeast Asia and North America. The oblique convergences and rotations resulted in the fragmentation, displacement, and duplication of formerly more nearly continuous arcs, subduction zones, and passive continental margins. These fragments were subsequently accreted along the expanding continental margins. (5) From the Early Jurassic through Tertiary, movement of the upper continental plates toward subduction zones resulted in strong plate coupling and accretion of the former island arcs and subduction zones to the continental margins. Accretions were accompanied and followed by crustal thickening, anatexis, metamorphism, and uplift. The accretions resulted in substantial growth of the North Asian and North American Continents. (6) During the middle and late Cenozoic, oblique to orthogonal convergence of the Pacific plate with present-day Alaska and Northeast Asia resulted in formation of the modern-day ring of volcanoes around the CircumNorth Pacific. Oblique convergence between the Pacific plate and Alaska also resulted in major dextral-slip faulting in interior and southern Alaska and along the western part of the Aleutian-Wrangell arc. Associated with dextral-slip faulting was crustal extrusion of terranes from western Alaska into the Bering Sea.

\section{Introduction}

We interpret a Phanerozoic tectonic model of the Circum-North Pacific (figs. 1,2) for the orogenic collages along the eastern margin of the North Asian Craton and the 
western margin of the North American Craton. These orogenic collages are composed of tectonostratigraphic terranes and overlap assemblages (see subsection below entitled "Key Terms..."). The tectonostratigraphic terranes consist mainly of accreted fragments of igneous arcs, accretionary-wedge and subduction-zone complexes, passive continental margins, and cratons. The overlap assemblages are sequences of mainly late Mesozoic and Cenozoic continental-margin-arc and sedimentary-basin assemblages that were deposited on subjacent tectonostratigraphic terranes or on terranes and subjacent cratonal-margin assemblages.

The basic data for the tectonic model are from a regional compilation and synthesis of a new tectonostratigraphic-terrane map of the Circum-North Pacific that includes the Russian Far East, northern Japan, Alaska, the Canadian Cordillera, the U.S. Pacific Northwest, the North Pacific Ocean, and the Arctic Ocean (Nokleberg and others, 1994a, 1997b, c). This synthesis, including stratigraphic, faunal, and structural data, enables correlation of terranes that were tectonically displaced from one another, grouping of coeval terranes into a single tectonic origin (for example, a single island arc or subduction zone), tectonic reconstruction of original positions, reconstruction of paths of tectonic migration, and interpretation of the tectonic setting of overlap assemblages, mainly continental-margin igneous arcs, during the Phanerozoic.

This report reviews what is known and what can reasonably be inferred about the geology and tectonic evolution of the onshore areas of the Circum-North Pacific. It consists of three parts: (1) an introduction and discussion of terms and concepts applied to the components of the Circum-North Pacific orogenic collage, (2) descriptions and interpretations of the origins of terranes and overlap assemblages within the collage, and (3) a model for the Phanerozoic tectonic evolution of the Circum-North Pacific. This report concentrates on the onshore geology and tectonics of major terranes and overlap assemblages that can be related to igneous arcs and subduction zones. Because of the absence of comparable geologic data, details of the geology and tectonics of offshore areas, principally the Pacific and Arctic Oceans, the Canada Basin, the Bering Sea, and the Sea of Okhotsk, are only briefly summarized herein. Only the important tectonic features are summarized for cratons and cratonal margins and the terranes derived from those units. No attempt is made herein to provide complete references because the literature is enormous and abundant data and interpretations have been incorporated into numerous, excellent recent syntheses (for example, Plafker and others, 1989b, Oldow and others, 1989; Gabrielse and Yorath, 1991; Burchfiel, 1992; Monger, 1993; Monger and others, 1994, Moore and others, 1994; Plafker and Berg, 1994; Monger and Nokleberg, 1996). This report draws on these syntheses and includes previously unpublished data that were jointly compiled and interpreted by the Russian and North American coauthors. Companion reports that present parts of this tectonic model are those by Natal'in (1993), Parfenov and others (1993a, b), Monger and Nokleberg (1996), and Parfenov (1997). Previous oral versions of the paper were presented by Nokleberg and others (1995b), Parfenov (1995a, b), and Monger and others (1996).
This report is the result of interpretation of extensive geologic mapping and associated tectonic studies in the CircumNorth Pacific during the past few decades. These studies suggest that most of this region consists of a series of faultbounded tectonostratigraphic terranes which were accreted onto the northeastern margin of the North Asian Craton and the northwestern margin of the North American Craton around the Circum-North Pacific mainly during the Mesozoic and Cenozoic (Saleeby, 1983; Parfenov, 1984, 1991, 1997; Howell and others, 1985; Parfenov and Natal'in, 1985; Watson and Fujita, 1985; Natal'in and others, 1986; Jones and others, 1987; Monger and Berg, 1987; Khanchuk and others, 1988, 1990, 1992, 1996; Fujita and Cook, 1990; Zonenshain and others, 1990; Natal'in, 1991, 1993; Silberling and others, 1992; Sokolov, 1992; Zinkevich and Tsukanov, 1992, 1993; Monger, 1993; Parfenov and others, 1993a, b, 1995; Moore and others, 1994a, b; Nokleberg and others, 1994a, 1997b, c; Plafker and Berg, 1994; Tabor, 1994; Monger and Nokleberg, 1996; Sokolov and Byalobzhesky, 1996; Khudoley and Sokolov, 1998). Earlier tectonic analyses of parts of the region were published by Box (1985a), Howell and others (1985), Parfenov and Natal'in (1985), and Plafker and Berg (1994).

This tectonic analysis employs six steps that have been accomplished by a large international collaborative team for the entire Circum-North Pacific region (Nokleberg and others, 1994a, 1997b, 1998): (1) define and utilize a systematic set of tectonic definitions; (2) compile, synthesize, and interpret a large number of stratigraphic, age, and structural data to construct regional terrane and overlap-assemblage maps, with detailed explanations, references, and stratigraphic columns; (3) perform systematic correlations of terranes and overlap assemblages, once parts of continuous geologic units, that were tectonically separated by rifting and (or) strike-slip faulting; (4) perform a systematic evaluation of correlations and tectonic linkages, as defined below; (5) systematically evaluate and employ higher quality paleomagnetic data (where not conflicting with stratigraphic and faunal data); and (6) construct a tectonic model that is based on the previous steps and in which the geologic units are scaled proportionally to those on the regional terrane and overlap-assemblage maps of the region (Nokleberg and others, 1994a, 1997b). This project also represents the first attempt by a large group of geologists from Russia, Alaska, and the Canada to interpret together the tectonic origin of this vast and geologically complex region of the Earth. The project consists of several geologists who have each gathered field data and observations in their respective parts of the Russian Far East, Alaska, and the Canadian Cordillera over many years and who have been able to work together in a large international team.

Three groups of figures provide important illustrations for this paper. The first group of figures (1-4) consists of four generalized geologic/tectonic maps for the region that are page-size simplifications of more detailed maps of major terranes, overlap assemblages, oceanic plates, rifts, major faults, and other major geologic features of the Circum-North Pacific. These figures are adapted from Nokleberg and others (1994a, 1997b, c) and Monger and Nokleberg (1996). One pair of figures $(1,2)$ shows major terranes; the other pair of figures $(3,4)$ shows major igneous-arc-related overlap assem- 
blages and subduction-zone terranes, mainly of Mesozoic and Cenozoic age. The second group of figures $(5,6)$ consists of plots of paleolatitude versus time for terranes and overlap assemblages in the Russian Far East, Alaska, and the Canadian Cordillera and for the North Asian and North American Cratons. Figures 5 and 6 and the companion data in table 3 summarize vital paleomagnetic data that can be used to interpret paleolatitudes through geologic time, when not conflicting with stratigraphic and structural data, in order to define paths of tectonic migrations through geologic time. The third group of figures (7-20) consists of 14 time-stage diagrams that portray, in schematic plan view, the tectonic evolution of the region from the Devonian through the present. Another set of figures, published by Nokleberg and others (1994a) and Greninger and others (1999), consists of 167 stratigraphic columns for major terranes in the study area. These stratigraphic columns, along with detailed descriptions of map units, provide base data for the delineation of terranes and sedimentary and igneous assemblages and permit correlations among or between terranes that have common tectonic environments.

\section{Acknowledgments}

We thank the many geologists who have worked with us for their valuable expertise in each region of Alaska, the Russian Far East, Hokkaido Island of Japan, the Canadian Cordillera, and the U.S. Pacific Northwest. In particular, we thank J.N. Aleinikoff, Yu.V. Arkhipov, H.C. Berg, R.B. Blodgett, S.E. Box, D.A. Brew, M.D. Bulgakova, Ch. B. Borukaev, D.C. Bradley, Howard Brooks, J. Decker, Cynthia DuselBacon, H.L. Foster, V.V. Gaiduk, B.M. Gamble, V.V. Golozubov, Arthur Grantz, D.G. Howell, D.L. Jones, S.M. Karl, S.V. Kovalenko, W.C. McClelland, E.M. MacKevett, Jr., A.V. Makhinin, M.V. Martynyuk, M.L. Miller, T.P. Miller, L.Ph. Mishin, E.J. Moll-Stalcup, T.E. Moore, S.W. Nelson, V.S. Oxman, S.A. Palanjan, I.V. Panchenko, T.L. Pavlis, L.I. Popeko, A.V. Prokopiev, J.C. Reed, Jr., D.H. Richter, S.M. Roeske, V.I. Shpikerman, N.J. Silberling, T.E. Smith, the late G.M. Sosunov, A.B. Till, F.F. Tret'yakov, A.N. Vishnevskiy, I.G. Volkodav, W.K. Wallace, G.R. Winkler, the late L.P. Zonenshain, and Yu.P. Zmievsky for their many fruitful discussions. We thank the late Ch.B. Borykaev, the late William R. Greenwood, Donald Grybeck, B.A. Morgan III, I.Ya. Nekrasov, A.T. Ovenshine, P.P. Hearn, A.A. Sidorov, T.E. Smith, D.J. Templeman-Kluit, and W.H. White for their encouragement and support of the project. We thank T.K. Bundtzen, S.G. Byalobzhesky, A. Grantz, K.G. Mackey, B.A. Natal'in, L.M. Natapov, G. Plafker, W.W. Patton, Jr., S.D. Sokolov, G.M. Sosunov, R.W. Tabor, N.V. Tsukanov, and T.L. Vallier for their fine work and discussions on the detailed terrane and overlap-assemblage map of the Circum-North Pacific (Nokleberg and others, 1994a) and on the tectonics of the region. We thank the North Atlantic Treaty Organization (NATO) for their support to David B. Stone for part of his work on this study under grant SA 12-2-02 (ENVIR.LG.930919)3912(93)LVdC. We thank various Rus- sian interpreters, including the late Lidiya I. Kovbas, Tatyana L. Koryakina, Tatyana N. Velikoda, and Elena V. Alekseenko, for their skill and assistance during long and complex scientific dialogs and for translation of complex geologic descriptions and references. We thank B.A. Natal'in for his participation in the compilation and synthesis of some of the Russian Southeast part of the terrane map of the CircumNorth Pacific. We thank Stephen G. Crumley for his compilation of paleomagnetic data. Finally, we thank Dwight Bradley, Mikhail Kuzmin, JoAnn Nelson, and Andrei Prokopiev for their constructive reviews of the manuscript.

\section{Associated Studies}

This study is part of a project on the major mineral deposits, metallogenesis, and tectonics of the Russian Far East, Alaska, and the Canadian Cordillera. The project provides critical information on bedrock geology and geophysics, tectonics, major metalliferous-mineral resources, metallogenic patterns, and the crustal origin and evolution of mineralizing systems of the region for collaborators and customers. The major scientific goals and benefits of the project are to (1) provide a comprehensive international data base for the mineral resources of the region that is the first extensive knowledge available in English; (2) provide major new interpretations of the origin and crustal evolution of mineralizing systems and their host rocks, thereby enabling enhanced, broad-scale tectonic reconstructions and interpretations; and (3) promote trade, scientific, and technical exchanges between North America and East Asia. Data from the project provide sound scientific data and interpretations for commercial firms, governmental agencies, universities, and individuals that are developing new ventures and studies in the project area and for land-use-planning studies that deal with mineral-resourcepotential issues. The Russian Far East part of the project (as well as Alaska and the Canadian Cordillera) has a vast potential for known and undiscovered mineral deposits; however, little information existed in English in the West until the publication of products from this project.

Published major companion studies for the project are (1) a report on the metallogenesis of mainland Alaska and the Russian Northeast (Nokleberg and others, 1993); (2) a tectonostratigraphic-terrane map of the Circum-North Pacific at a scale of 1:5,000,000, with a detailed explanation of map units and stratigraphic columns (Nokleberg and others, 1994a; Greninger and others, 1999); (3) a summary terrane map of the Circum-North Pacific at a scale of 1:10,000,000 (Nokleberg and others, 1997b); (4) detailed tables of mineral deposits and placer districts in the Russian Far East, Alaska, and the Canadian Cordillera in paper format (Nokleberg and others, 1996) and in CD-ROM format (Nokleberg and others, 1997a); (5) a GIS presentation of a summary terrane map, mineral-deposit maps, and metallogenic-belt maps of the Russian Far East, Alaska, and the Canadian Cordillera (Nokleberg and others, 1998); and (6) a GIS compilation of geophysical, geologic, and tectonic data for the Circum-North Pacific (Greninger and others, 1999). 
A complete listing of the project goals and methods is available on the Internet/World Wide Web at URL http://minerals.er.usgs.gov/wr/projects/majdeps.html. Major recent articles on the project (Nokleberg and others, 1993, 1994a, 1996, 1997a-c, 1998) are available at URL http:// wrgis.wr.usgs.gov, This project was started at the invitation of the Soviet Academy of Sciences to the U.S. Geological Survey in 1988. Subsequently, several organizations and many individuals volunteered to work on various aspects of the project, producing a large variety of articles and maps. Other organizations participating in the project include the Russian Academy of Sciences, ROSKOMNEDRA (now the Russian Ministry of Natural Resources), the Alaska Division of Geological and Geophysical Surveys, the Geological Survey of Canada, the Geological Survey of Japan, the Exxon Exploration Co., the University of Alaska, and Michigan State University.

\section{Key Terms for Tectonic Analysis of the Circum- North Pacific}

Three key terms for this analysis, defined in table 1 along with other important tectonic terms, are "tectonostratigraphic terrane," "accretion," and "overlap assemblage."

1. A tectonostratigraphic terrane (hereinafter referred to as terrane) is a fault-bounded geologic entity or fragment that is characterized by a distinctive geologic history which differs markedly from that of adjacent terranes. A terrane can also consist of an intensely deformed structural complex bounded by faults. Some terranes may be displaced facies of other terranes. Stratigraphic, faunal, and paleomagnetic evidence suggests that some terranes originally were widely separated from one another, or from the cratons of either North America or North Asia, by distances of as much as thousands of kilometers (Plafker and Berg, 1994). Other terranes, however, are interpreted to be displaced from one another, or from another site on the same continent, by distances of only hundreds of kilometers or less.

2. Accretion is the tectonic juxtaposition of two or more terranes, or the tectonic juxtaposition of terranes to a cratonal margin, and defines a major change in the tectonic evolution of the terranes and cratonal margins. Geologic units formed before accretion (preaccretionary units) are inherent to the stratigraphy of the terrane. Geologic units formed after accretion (postaccretionary units) constitute mainly overlap assemblages that formed during a new stage in the tectonic evolution of the region.

3. An overlap assemblage is a postaccretionary unit of sedimentary or igneous rocks deposited on, or intruded into, two or more adjacent terranes or a cratonal margin. The unit depositionally overlies, or is interpreted to have originally depositionally overlain, two or more adjacent terranes, or terranes and the cratonal margin. Overlapping plutonic rocks, which may be coeval and genetically related to overlap volcanic rocks, link or stitch together adjacent terranes, or a terrane and a cratonal margin. The formation of an overlap assemblage defines a major change in the tectonic evolution of terranes and cratonal margins and also provides a minimum age for terrane accretion.

In this tectonic model, terranes are delineated according to the following interpreted dominant types of tectonic environment (table 1): (1) cratonal; (2) passive continental margin; (3) metamorphosed continental margin; (4) continental-margin arc; (5) island arc; (6) oceanic crust, seamount, or ophiolite; (7) accretionary wedge and subduction zone; (8) turbidite basin; and (9) metamorphic, for terranes that are so highly deformed and (or) metamorphosed that determination of the original tectonic environment is difficult to determine. For terranes with complex geologic histories, the chosen tectonic environment is the one most prevalent during the history of the terrane.

\section{Method of Tectonic Analysis}

To model such a large, widespread, and diverse set of tectonic assemblages, this study undertakes an empirical approach to terrane analysis. First, terranes are classified according to major tectonic environments. Second, correlations are attempted between terranes of the same tectonic environment, similar age, and similar paleomagnetic latitudes (for terranes having paleomagnetic data that do not conflict with stratigraphic and faunal data). Third, igneous-arc terranes (both island-arc and continental-margin-arc terranes) are grouped or tectonically linked with coeval accretionary-wedge or subduction-zone terranes in a manner that is common around the present-day Pacific margin. In addition, the ancient Pacific margin is interpreted as broadly similar to the modern margin, that is, as a series of continuous igneous arcs that separate continents and subducting oceanic plates.

This approach is supported by three lines of reasoning. First, the bulk of stratigraphic, faunal, and some paleomagnetic data do not require large separations of most igneous-arc terranes from either North America or Northeast Asia. Certain exceptions are the truly exotic Tethyan fauna that occur in the Late Permian Cache Creek subduction-zone terrane in the North American Cordillera. Second, the ancestral Pacific Ocean is considered to have resembled the modern one, in that it was bordered discontinuously by paired igneous arcs and subduction zones. Third, most igneous arcs and companion subduction-zone complexes did not migrate across the ancestral Pacific Ocean. A notable exception to the last item is the Wrangellia superterrane, which originated near the Late Triassic paleoequator and was accreted to the North American Continent at a higher paleolatitude during the Cretaceous and early Cenozoic.

Although the incompleteness of the geologic data leaves considerable paleogeographic uncertainty that increases markedly with the age of units, the chief result of this interpretative tectonic model is a series of time-stage diagrams that successively depict the arrangements of continents, active continental margins, subduction zones, spreading ridges, and oceanic plates during the Phanerozoic. Our time-stage diagrams are based on carefully evaluated data that were compiled from various sources published by a large group of earth 
scientists. We look forward to the accumulation of more data and refinement of the tectonic model presented herein.

\section{Complementary Terms: Terranes and Tectonic Components}

Two types of tectonic analysis have been employed to decipher the disorder inherent along the accretionary margins of continents, such as the North American Cordillera. One type emphasizes the origins of parts of the tectonic collage as distinct tectonostratigraphic terranes, whereas the other type emphasizes the components of the tectonic collage. These two types of tectonic analysis are complementary. Analysis of terranes defines the basic units, whereas analysis of components of collages adds an interpretation to the origin of units.

\section{Analysis of Terranes}

Rock associations that are characterized by the tectonic settings in which they formed, such as cratonal margins, arcs, and ocean basins, have been used since plate-tectonic concepts first were applied to Cordilleran geology (for example, Hamilton, 1969). Termed "tectonic assemblages" (Wheeler and McFeely, 1991; Wheeler and others, 1991), "tectonostratigraphic elements" (Burchfiel, 1992), or "tectonostratigraphic terranes" (Jones and others, 1981, 1983, 1984), they constitute major units of new geologic and tectonic maps of the Canadian and adjacent U.S. segments of the North American Cordillera.

Regions whose geology and, in some places, stratigraphic, faunal, and paleomagnetic data differ from those of adjoining regions and from rocks of the cratonal margin, and which are separated from neighboring regions by major faults, are called "suspect" or "lithotectonic terranes" (Coney and others, 1980; Silberling and others, 1992). Delineation of terranes focuses attention on the nature and times of linkages between them and shows how the tectonic collage was constructed. The concept long predates the plate-tectonic hypothesis; terranes are analogous to Alpine nappes or to the massifs and intervening regions in central Asia, as described by Argand (1924). Well before terranes were widely promoted, parts of the Cordilleran eugeosyncline had been identified as "fragments of Asia" (Wilson, 1968, fig. 6; later the Stikinia, Alexander, and Sonomia terranes), the "Alexander terrane" (Berg and others, 1972), and the "Atlin terrane" (Wheeler and Gabrielse, 1972), now part of the Cache Creek terrane.

Genetic terminology is readily married to terranes (for example, Silberling and others, 1992). The North American Cordilleran tectonic collage includes accreted terranes composed of juvenile arc rocks, ocean-floor deposits and their underlying lithosphere, and continental-margin terranes containing abundant detritus derived from a craton (fig. 1). For example, the Cache Creek Complex is a terrane composed of oceanic offscrapings that were accreted into an early Mesozoic accretionary complex. Another example, in northwestern
British Columbia, contains four mid-Paleozoic through early Mesozoic arc assemblages separated from one another by unconformities. The paleoposition of each arc assemblage is uncertain, but together they compose the Stikinia terrane, which was accreted during the Middle Jurassic to form a major component of the North American Cordilleran tectonic collage. Still other terranes contain rocks representing more than one tectonic setting, although one setting is generally dominant; for example, Devonian arc rocks form overlap assemblages on parts of several passive-continental-margin terranes in the North American Cordillera.

\section{Analysis of Components of Tectonic Collages}

The widely used terrane concept has been strongly criticized by Sengör (1990), among others. He proposed use of the terms "primary orogenic collage components" for fragments accreted by closing intervening ocean basins, and "secondary orogenic collage components" for fragments displaced within the already-accreted collage by strike-slip or other large faults. At first sight, the location of major arc terranes (for example, the Kony-Murgal, Stikinia, and Quesnellia terranes and the Wrangellia superterrane; see fig. 7), oceanward of an early Mesozoic accretionary complex, suggests that they are primary components. However, their locations are known with some degree of certainty only after they became part of the North American Cordilleran collage and interacted with other terranes and cratonal-margin deposits, as they did during the Mesozoic. We argue herein that at least the Mesozoic parts of the oceanward arc terranes are more likely segments of the same ancestral Pacific Ocean arc system which were displaced along the North American plate margin, rather than being separate arcs that migrated across oceans. Because the distinction between primary and secondary components may be impossible in practice to make without paleogeographic control, the term "terrane" is needed in this type of tectonic analysis. In spite of any terminology differences, our analysis of the tectonic collage around the Circum-North Pacific is similar in principle to that put forward by Sengör and others (1993) for the Paleozoic tectonics of central Asia, although we admit more paleogeographic uncertainty. His "first-order units" of the Altaid collage are comparable to North American Cordilleran terranes.

\section{Methods for Correlation, Linkage, and Alignment of Major Terranes and Overlap Assemblages}

Interpretation of the geology and tectonics of the CircumNorth Pacific presents a major challenge because of the complex variety and number of geologic units in the region and because of the complex tectonic history of the region. The detailed and summary terrane and overlap-assemblage maps of this region, which support our tectonic analysis, define 167 terranes, 2 cratons, 2 cratonal margins, 71 overlap assemblages, and 3 oceanic plates (summarized in figs. 1-4; Nokle- 
berg and others, 1994a, 1997b; Greninger and others, 1999). To understand this complex array of geology and thereby construct a relatively detailed tectonic interpretation, three major steps are employed: (1) correlation, (2) tectonic pairing (linking), and (3) alignment of coeval arc and tectonically linked subduction zones into curvilinear complexes. Previous correlations of bedrock geology and tectonic activity between the Russian Far East and Alaska were published by Box (1985a), Howell and others (1985), Parfenov and Natal'in (1985), and Parfenov (1997).

\section{Correlation of Terranes and Overlap Assemblages}

The first major step for this tectonic analysis is the correlation of similar coeval terranes and overlap assemblages (table 2). Correlation can be achieved because terranes and overlap assemblages are working-level geologic entities that are defined by geologic mapping and stratigraphic analysis.
In this tectonic analysis, correlation is attempted for terranes and overlap assemblages that are interpreted as having been originally contiguous but have subsequently been tectonically displaced during rifting or major thrusting, or displaced along late Mesozoic and Cenozoic strike-slip and thrust faults. Correlations are attempted for all units (both terranes and overlap assemblages) that are interpreted to have the same tectonic origin (as parts of a single elongate passive continental margin, island arc, or subduction zone), at the same time and adjacent to each other. For some units, correlated terranes and overlap assemblages do not always exhibit identical stratigraphy but do share a common age, geographic position (reconstructed in some cases), and tectonic environment that indicate a tectonic origin as part of the same continental margin, island arc, or subduction zone.

An important step for this study is the correlation, where possible, of cratonal and passive-continental-margin terranes to either the North Asian Craton or cratonal margin, or to the North American Craton or cratonal margin. This type of correlation helps establish the Late Proterozoic and Paleozoic

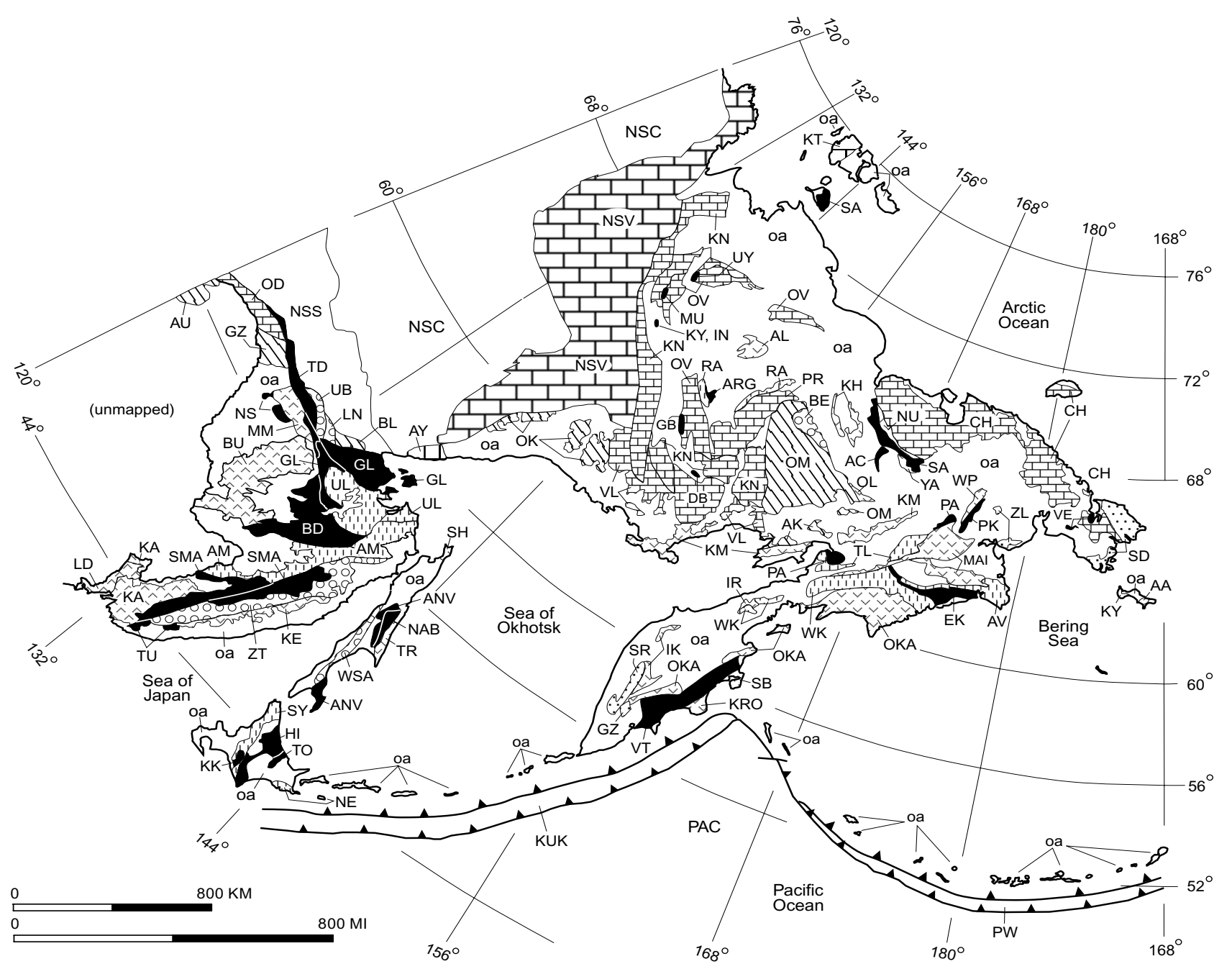

Figure 1.-Generalized terrane map of the Russian Far East, northern Japan, and adjacent offshore areas, showing locations of major terranes, major oceanic plates, major offshore faults, and tectonic environment. Adapted from Nokleberg and others (1994a, 1997a, b). 
geology of the Circum-North Pacific before various episodes of rifting and accretion. Correlations are summarized in table 2 and explained below. Correlations were achieved by Nokleberg and others (1994a, 1997b) by (1) interpreting tectonic environments for all major units (figs. 1-4); (2) comparing their geologic characteristics, including stratigraphic, magmatic, structural, metamorphic, paleontologic, isotopic, and paleomagnetic data (where not conflicting with other geologic data) for units with the same tectonic environment; and

\begin{tabular}{|c|c|}
\hline & EXPLANATION \\
\hline oa & $\begin{array}{l}\text { Overlap assemblages } \\
\text { (Cretaceous and Cenozoic) }\end{array}$ \\
\hline & CRATON \\
\hline $\begin{array}{l}\text { NSC } \\
\text { NSS }\end{array}$ & $\begin{array}{l}\text { NSC North Asian Craton } \\
\text { NSS North Asian Craton - Stanovoy block }\end{array}$ \\
\hline & $\begin{array}{l}\text { North Asian Craton Margin } \\
\text { (Verkhoyansk fold and thrust belt) }\end{array}$ \\
\hline & ITONAL TERRANES \\
\hline & $\begin{array}{l}\text { AK Avekova; AU Argun; BL Baladek; } \\
\text { GZ Gonzha; OK Okhotsk; OM Omolon }\end{array}$ \\
\hline SI & CONTINENTAL-MARGIN TERRANES \\
\hline | & $\begin{array}{l}\text { AA Arctic Alaska; AY Ayansk; CH Chukotka; } \\
\text { KN Kula-Nera; OD Oldoi; OV Omulevka; } \\
\text { PL Prikolyma; VL Viliga }\end{array}$ \\
\hline ME & RPHOSED CONTINENTAL-MARGIN TERRANES \\
\hline & $\begin{array}{l}\text { SD Seward; SR Sredinny-Kamchatka; } \\
\text { ZL Zolotogorskiy }\end{array}$ \\
\hline & $\begin{array}{l}\text { CRETED TERRANES } \\
\text { Continental-margin arc terranes }\end{array}$ \\
\hline & $\begin{array}{l}\text { BU Bureya; KE Kema; KA Khanka; } \\
\text { MM Mamyn }\end{array}$ \\
\hline & Island-arc terranes \\
\hline & $\begin{array}{l}\text { AL Alazeya; IR Iruneiskiy; KM Kony-Murgal; } \\
\text { KRO Kronotskiy; KH Khetachan; KY Koyukuk; } \\
\text { LD Laoelin-Grodekorsk; MAI Mainitskiy; } \\
\text { NE Nemura; NU Nutesyn; OKA Olyutorka-Kamchatka; } \\
\text { OL Oloy; SB Stolbovskoy; SH Shmidt, } \\
\text { TR Terpeniya; WP West Pekulney; YA Yarakvaam }\end{array}$ \\
\hline & $\begin{array}{l}\text { Accretionary-wedge, subduction-zone, } \\
\text { or ophiolite terranes }\end{array}$ \\
\hline & Dominantly oceanic rocks: \\
\hline & $\begin{array}{l}\text { AG Angayucham; AC Aluchin; ANV Aniva; ARG Argatas; } \\
\text { BD Badzhal; DB Debin; EK Ekonay; GB Garbynya; } \\
\text { GL Galam; HI Hidaka; IN Indigirka; KK Kamuikotan; } \\
\text { KYB Kybytygas; MU Munilkan; NAB Nabilsky; } \\
\text { NS Nora-Sukhotin; PA Penzhina-Anadyr; PK Pekulney; } \\
\text { SA South Anyui; SMA Samarka; TD Tukuringra-Dzhagdi; } \\
\text { TO Tokoro; TU Taukha; UY Uyandina; VE Velmay; } \\
\text { VT Vetlovskiy } \\
\text { Dominantly turbidites: }\end{array}$ \\
\hline 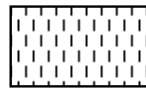 & $\begin{array}{l}\text { AM Amur River; AV Alkatvaam; KUK Kuril-Kamchatka; } \\
\text { PW Prince William; RA Rassokha; SY Sorachi-Yezo; } \\
\text { TL Talovskiy; UL Ulban; week West Kamchatka }\end{array}$ \\
\hline & Turbidite-basin terranes: \\
\hline 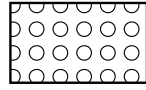 & $\begin{array}{l}\text { BE Beryozovka; LN Lan; SY Sorachi-Yezo; } \\
\text { UB Uniya-Bom; WSA West Sakhalin; } \\
\text { ZT Zhuravlesk-Tumnin }\end{array}$ \\
\hline AC & Pacific oceanic plate \\
\hline & Contact \\
\hline & Active subduction zone \\
\hline
\end{tabular}

(3) comparing the stratigraphy of units as illustrated in the 167 stratigraphic columns for major terranes and overlap assemblages around the Circum-North Pacific (Nokleberg and others, 1994a; Greninger and others, 1999). This correlation of terranes and overlap assemblages (1) illustrates the original continuity of rock units in the Circum-North Pacific, (2) provides important constraints on the past tectonics of the region, and (3) constitutes a series of interpretations to be further evaluated by additional stratigraphic, geochemical, isotopic, paleomagnetic, and geophysical studies.

\section{Tectonic Pairing (Linkage)}

The second major step for this tectonic analysis is tectonic pairing (linkage) (table 2). Two types of this pairing are utilized in this study: (1) tectonic pairing of subductionrelated igneous arcs, now preserved as various igneous-arc terranes or overlap assemblages, to former subduction zones, now preserved as accretionary-wedge or subduction-zone terranes; and (2) tectonic pairing of belts of anatectically related igneous rocks and major faults (sutures) that bound terranes. Tectonic pairings are summarized in table 2 and below.

The first type of tectonic pairing is based on (1) analyzing the stratigraphy and structure of terranes to determine the tectonic environment, by defining an igneous arc or subduction zone or a related tectonic environment; (2) interpreting a physical proximity, as when specific igneous-arc terranes were originally adjacent to specific subduction zones; (3) interpreting linkages between collisional foreland basins and collisional orogens; (4) determining the similarity in age of formation of igneous-arc and subduction-zone terranes; (5) determining subduction polarity from tectonic transport direction in a melange for subduction-zone and accretionarywedge terranes, where not disrupted by later deformation; and (or) (6) recognizing the occurrence of disrupted layers of arcderived volcanic or volcaniclastic units from a specific igneous arc, where possible, in the melange of the (companion) accretionary-wedge or subduction-zone terrane.

The second type of tectonic pairing is based on the spatial and temporal association of collisional ( $\mathrm{S}$ type) granitic plutons and associated volcanic rocks with (1) major fault zones (sutures) between terranes or between a terrane and a cratonal margin, and (or) (2) belts of highly deformed, regional-grade metamorphic rocks that occur along the fault zones. Anatectically related igneous belts are interpreted as having formed either during the accretion of one terrane to another or during the accretion of one or more terranes to a cratonal margin.

\section{Alignment of Coeval Arcs and Subduction Zones}

The third major step for this tectonic analysis is the grouping of terranes and overlap assemblages into larger entities that were probably once continuous igneous arcs and companion subduction-zone (or accretionary wedge) complexes. Those grouping of coeval units is based, to varying 
degrees, on (1) similar stratigraphy, fauna, rock-unit age, and structure; (2) to a lesser degree, paleomagnetic data; and (3) an assumption of simplicity. The result of these groupings is the alignment of coeval igneous-arc overlap assemblages and igneous-arc terranes, and tectonically linked (companion) accretionary-wedge and subduction-zone terranes, into coeval, curvilinear arc/subduction-zone complexes. This philosophy results in the interpretation of single rather than multiple continental-margin or island-arc/subductionzone complexes. Alignment of coeval arcs and subduction zones are illustrated below in various parts of the tectonic model (figs. 7-20).

\section{Problems of Correlations, Tectonic Linkages, and Alignments}

Our correlations, tectonic linkages, alignments of terranes and overlap assemblages, and the derivative tectonic model will probably change as additional data are acquired and new ideas are created. Our tectonic model is more highly developed for the later Mesozoic and Cenozoic stages when correlations and linkages can be made between the units accreted to the North Asian and North American Cratons. Some prob- lems are inherent to the correlation, linkage, and alignment of terranes and overlap assemblages. For terranes that originated during rifting of cratonal margins and have since undergone suborthogonal convergence, terrane correlation is relatively simple. More complex problems arise when large-scale strikeslip faults interfere with the interpretation of terrane origin, dispersion, accretion, and postaccretionary history.

\section{Descriptions of Geology, Correlations, and Linkages of Major Terranes and Overlap Assemblages}

A detailed description and interpretation of the geology, correlations, and tectonic linkages of major terranes and overlap of the Circum-North Pacific is presented here. Units are described and interpreted in the following order: (1) continental-margin and cratonal terranes; (2) late Paleozoic through mid-Cretaceous island-arc terranes of the Wrangellia superterrane; (3) Triassic through mid-Cretaceous continental-margin arcs, island arcs, and tectonically paired subduction zones; (4) Late Cretaceous and early Cenozoic continental-margin arcs, island arcs, and tectonically paired subduction zones; (5)

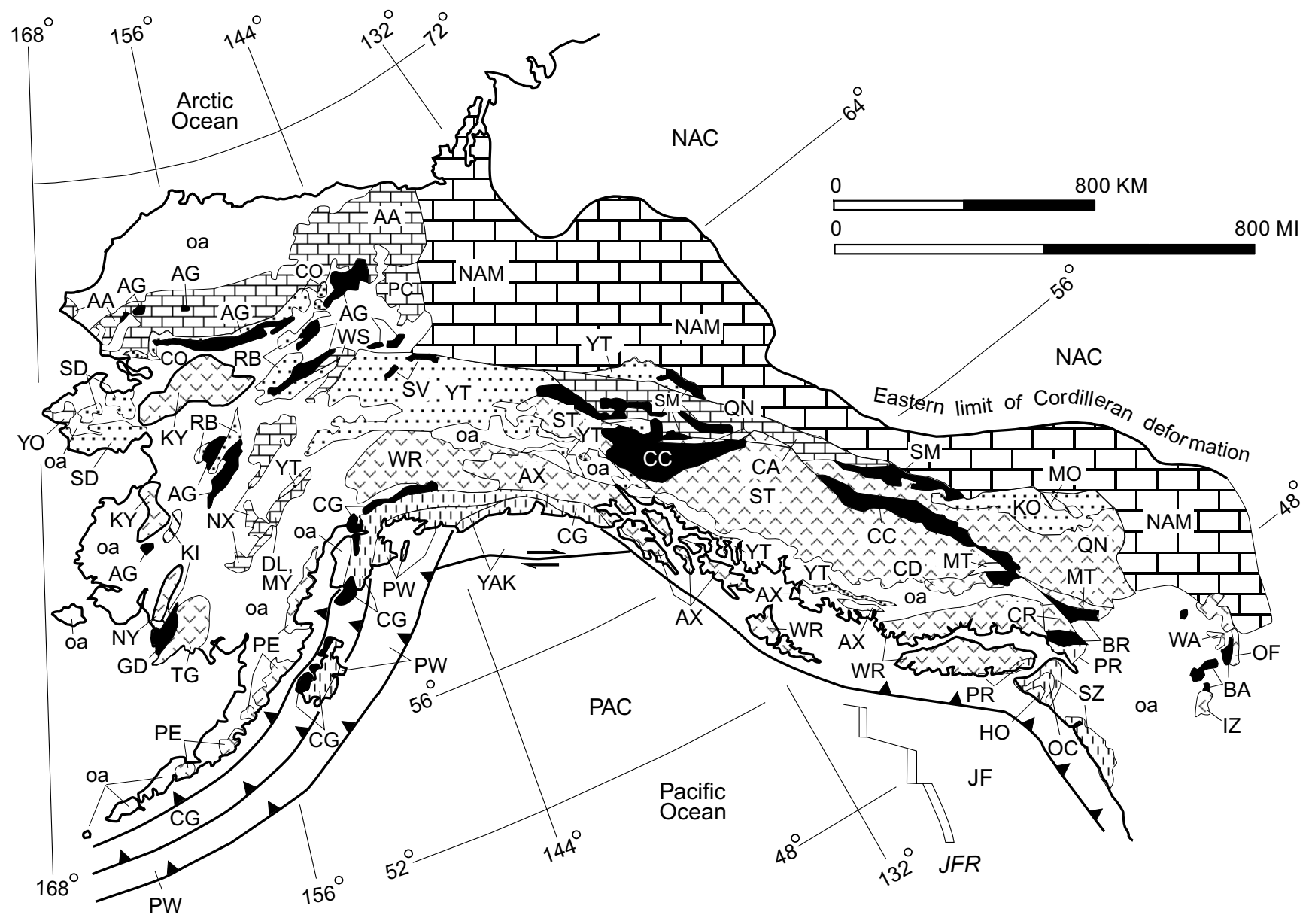

Figure 2.-Generalized terrane map of Alaska, the Canadian Cordillera, and adjacent offshore areas, showing locations of major terranes, major oceanic plates, major offshore faults, and tectonic environment. Adapted from Nokleberg and others (1994a, 1997a, b) and Monger and Nokleberg (1996). 
middle and late Cenozoic continental-margin arcs and tectonically paired subduction zones; and (6) linkages between belts of anatectically related igneous rocks and accretions of terranes. Within each group, the descriptions and interpretations are presented in counterclockwise order, starting with the Russian Southeast and ending with southeastern Alaska and the southern part of the Canadian Cordillera. The correlations and tectonic linkages of terranes and overlap assemblages for the Circum-North Pacific are summarized in table 2.

\section{EXPLANATION}

\begin{tabular}{|c|c}
\hline oa & $\begin{array}{c}\text { Overlap assemblages } \\
\text { (Cretaceous and Cenozoic) } \\
\text { CRATON AND CRATON MARGIN }\end{array}$ North American Craton \\
\hline NAC & KI Kilbuck-Idono; MO Monashee
\end{tabular}

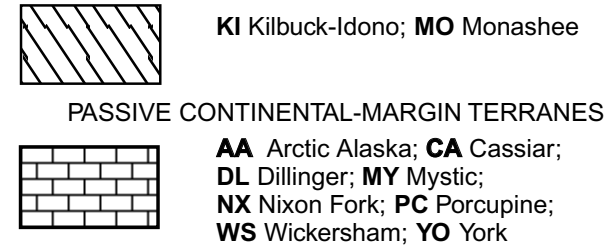

METAMORPHOSED CONTINENTAL-MARGIN TERRANES

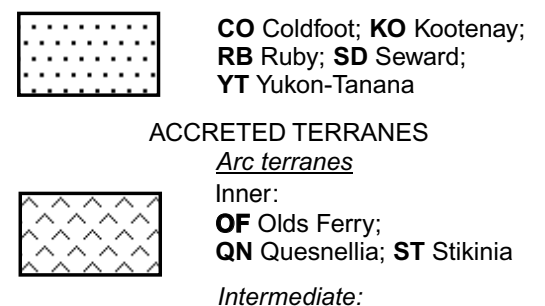

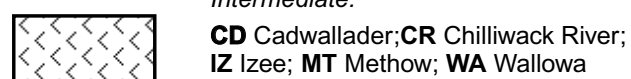
< $<<<<$ IZ Izee; MT Methow; WA Wallowa

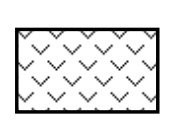

Outer:

AX Alexander; KY Koyukuk; NY Nyac; PE Peninsular; TG Togiak; WR Wrangellia

Accretionary-wedge and subduction-zone terranes

Dominantly oceanic rocks:

AG Angayucham; BA Baker;

BR Bridge River; CC Cache Creek;

CG Chugach; GD Goodnews;

SM Slide Mountain; SV Seventymile

Dominantly turbidites:

CG Chugach (part); GS Grindstone; HO Hoh; OC Olympic Core; PR Pacific Rim;

PW Prince William; SZ Siletzia; YAK Yakutat;

OCEANIC PLATES AND RIDGES

JF Juan de Fuca; PAC Pacific;

$J F R$ Juan de Fuca oceanic ridge

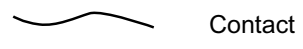

Active subduction zone

Active strike-slip fault

\section{Cratons, Cratonal Terranes, Passive Continental Margins, and Passive- Continental-Margin Terranes}

The eastern part of the North Asian Craton (NSC, NSS, figs. 1,3,7) and the western part of the North American Craton (NAC, figs. 2, 4, 7) bound the western and eastern parts of the Circum-North Pacific, respectively. Adjacent to these cratons are two major passive continental (cratonal) margins: the North Asian cratonal margin (Verkhoyansk foldand-thrust belt; NSV, figs. 1, 3,7) to the west, and the North American cratonal margin (NAM, figs. 2,7) to the east. Adjacent to the passive continental margins is a wide collage of terranes that were accreted to the cratonal margins principally during the Mesozoic and Cenozoic (figs. 1,2). More descriptions of, and stratigraphic columns for, the 167 accreted terranes and the cratons and cratonal margins were provided by Nokleberg and others (1994a) and Greninger and others (1999). The growth of continental margins by terrane accretion is an amazing facet of the tectonic history of the region. Most of the accreted terranes are herein interpreted as derived from various parts of the cratons, cratonal margins, or fringing island arcs and companion subduction-zone complexes.

\section{Continental-Margin and Cratonal Terranes in the Russian Southeast}

A complex suite of continent-related terranes in the Russian Southeast are interpreted as tectonically derived from various parts of the North Asian Craton and cratonal margin (NSC, NSV, NSS, figs. 1, 3, 7), the North China Craton to the south (not shown in fig. 1), or the Sino-Korean Craton to the south (also not shown in fig. 1). These terranes, mainly of Archean, Late Proterozoic, and (or) early Paleozoic age, consist of the Argun (AU), Baladek (BL), and Gonzha (GH) cratonal terranes; the Ayansk (AY), and Oldoi (OD) passivecontinental-margin terranes; the Khanka continental-marginarc superterrane (KA); and the Bureya (BU) and Mamyn (MM) continental-margin-arc terranes (fig. 1). This suite of continent-related terranes has a complex origin. Various interpretations were proposed by Natal'in (1991, 1993), Sengör and others (1993, 1994), Khanchuk and others (1996), and Sengör and Natal'in (1996a, b).

\section{Origin of the Khanka Continental-Margin-Arc Superterrane and the Laoelin-Grodekorsk Island-Arc Terrane}

The Khanka continental-margin-arc superterrane (KA, fig. 1), composed mainly of fragments of a Late Proterozoic and Paleozoic continental-margin arc and one accretionarywedge complex, occurs in the southern part of the Russian Far East. Adjacent is the Permian Laoelin-Grodekorsk islandarc terrane (LD, figs. 1, 7). The Khanka superterrane consists of a series of related, early and middle Paleozoic continental-margin-arc and accretionary-wedge terranes, including the 
Kabarga, Sergeevka, and Voznesenka continental-margin-arc terranes and the Spassk accretionary-wedge terrane (predominantly turbidites) (Nokleberg and others, 1994a; Khanchuk and others, 1996), all of which are too small to show in figure 1. The Khanka superterrane includes overlapping units of Devonian and Mississippian continental-rift-related volcanic and sedimentary rocks, middle Paleozoic granitic rocks, late Paleozoic granitic rocks, and Permian backarc-rift-related volcanic rocks.

The Voznesenka terrane, which forms the southern part of the Khanka superterrane, is interpreted as part of an early Paleozoic continental-margin arc or passive continental margin that was part of the Gondwanaland supercontinent (Khanchuk and others, 1996). Archaeocyathids from Cambrian limestone in the Voznesenka terrane belong to the Australian paleobiogeographic province (Belyaeva, 1998). To the north of the Voznesenka terrane are the early and middle
Paleozoic Sergeevka and Kabarga continental-margin-arc terranes. These two terranes, and the Bureya continental-marginarc superterrane farther north (fig. 1), also of early and middle Paleozoic age, are all interpreted as parts of a single continental-margin arc (Khanchuk and others, 1996) that formed along the margin of the paleo-Asian Ocean along the eastern Gondwanaland margin during the latest Precambrian and Cambrian. The Spassk accretionary-wedge terrane, containing mainly early and middle Paleozoic oceanic rocks and turbidite deposits and also constituting part of the Khanka superterrane, is interpreted as a subduction-zone complex that was tectonically linked to the arc.

The Khanka superterrane is interpreted as having been rifted from the Gondwanaland supercontinent during the Devonian, resulting in the formation of bimodal volcanic rocks. The Permian marine and nonmarine volcanic and terrigenous deposits that overlie most of the various terranes

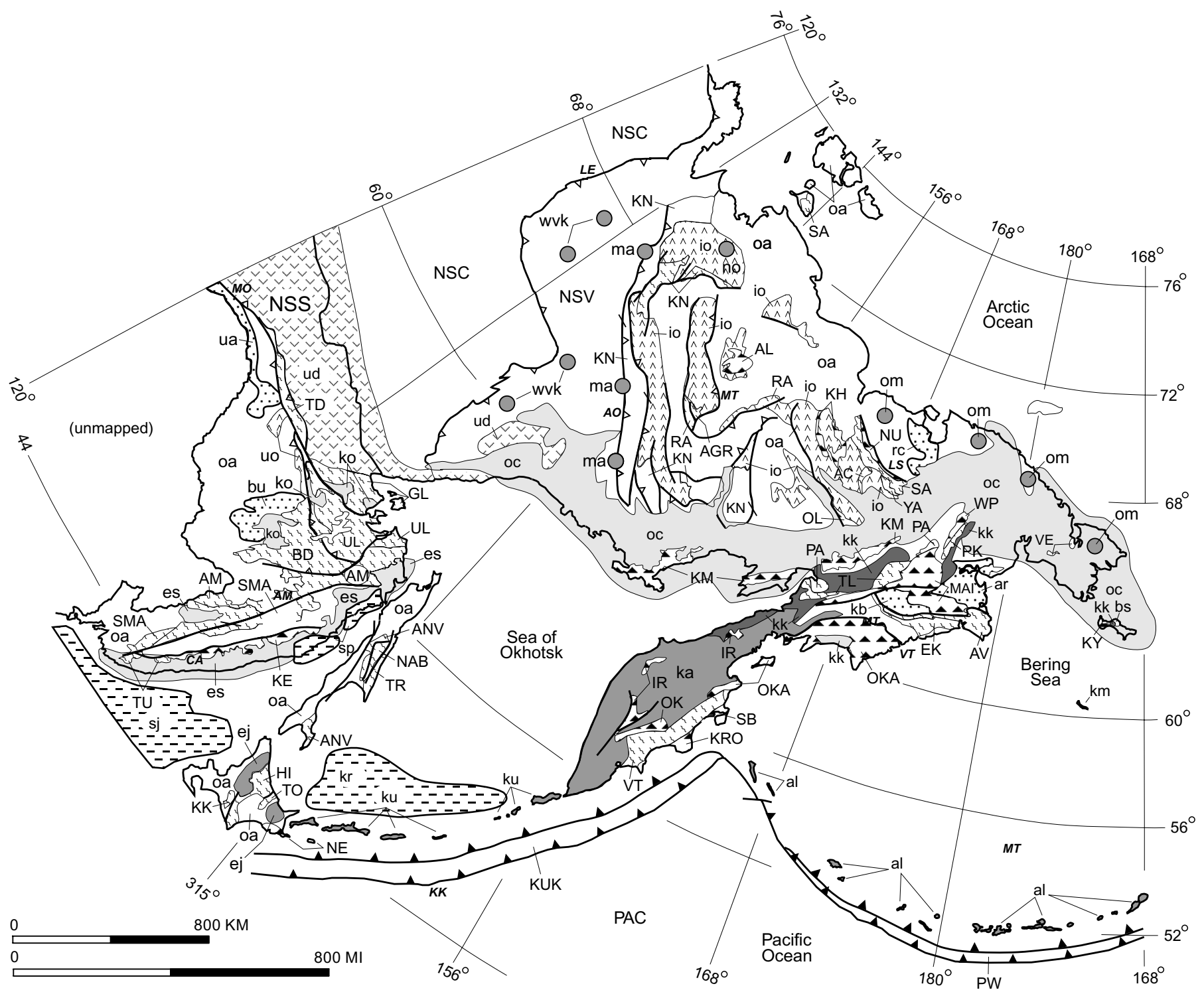

Figure 3.-Generalized map of the Russian Far East, northern Japan, and adjacent offshore areas, showing locations of overlap assemblages, tectonically linked subduction zones, major oceanic plates, and major faults. Adapted from Nokleberg and others (1994a, 1997a, b). 
of the Khanka superterrane are interpreted as having formed in a backarc basin adjacent to the Permian island arc of the Laoelin-Grodekorsk terrane (LD, figs. 1, 7), in a tectonic setting similar to that of the modern Sea of Japan (Khanchuk and others, 1996). These data and interpretations indicate that the Khanka superterrane is a complex unit composed of fragments of diverse tectonic settings (Khanchuk and others, 1996) and is not a part of the Sino-Korean Craton (as interpreted by Sengör and Natal'in, 1996a, b).

In contrast, the Khanka continental-margin-arc superterrane (KA, fig. 1) in the southern part of the Russian Southeast is interpreted by other workers (Natal'in 1991, 1993; B.A. Natal'in, in Nokleberg and others, 1994a) as derived from part of the Sino-Korean Craton on the Korean Peninsula (not shown in fig. 1) where similar Early Cambrian shelf carbonates occur, and was tectonically separated from this region during Mesozoic strike-slip faulting.
The Permian Laoelin-Grodekorsk island-arc terrane (LD, figs. 1, 7), which occurs to the west of the Khanka superterrane (KA, fig. 1), is tectonically linked to various Permian accretionary-wedge terranes to the south, southwest, and southeast (Khanchuk and others, 1996). These accretionary-wedge terranes include the Chongjin terrane (outside area of fig. 1) which extends westward from the coast of the Japan Sea (Chongjin city area) probably into southern Mongolia, in the area between the Khanka superterrane and the Sino-Korean Craton. The Chongjin terrane contains large blocks of middle and late Paleozoic ophiolites, bedded chert, and limestone and is interpreted as having formed in a subduction zone. Collision of the SinoKorean Craton and the Khanka superterrane, and closing of the ocean between the two terranes, is interpreted as occurring during the Early Triassic (Zonenshain and others, 1990).

\section{EXPLANATION}

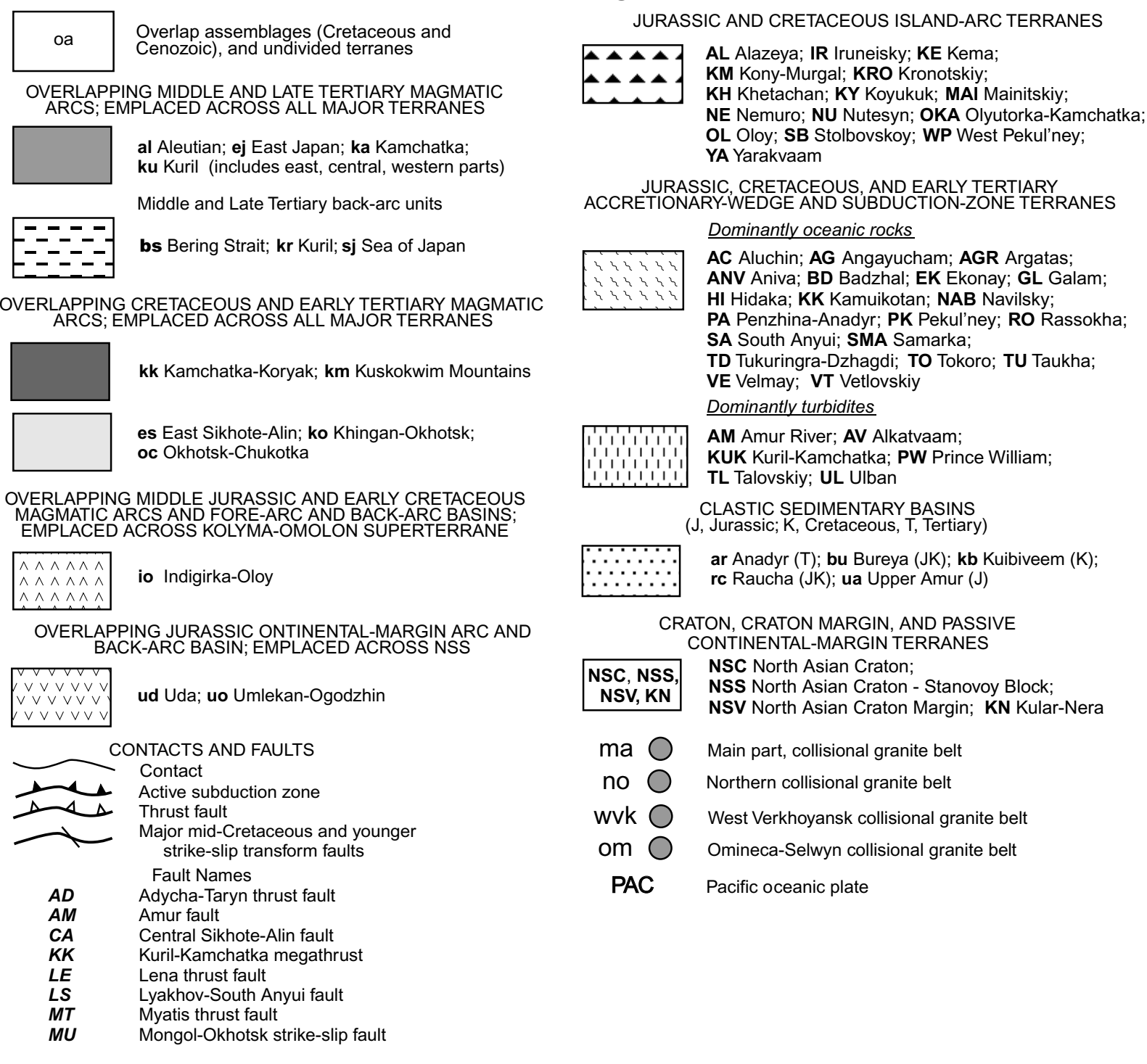




\section{Origin of the Argun, Baladek, and Gonzha Cratonal Terranes, the Ayansk and Oldoi Passive-Continental-Margin Terranes, and the Mamyn and Bureya Continental- Margin-Arc Terranes}

Three major groups of cratonal, passive-continental-margin, and continental-margin-arc terranes, of mainly Archean and Proterozoic age (cratonal terranes) and mainly early and middle Paleozoic age (continental-margin-arc and passive-continental-margin terranes), occur in the northern part of the Russian Southeast (fig. 1). The origin of each of these three groups is interpreted as follows. (1) The Argun (AU) and Gonzha (GZ) cratonal terranes, the early and middle Paleozoic Oldoi (OD) passive-continental-margin terrane, and the Proterozoic to Early Cambrian part of the Mamyn (MM) continentalmargin-arc terrane (fig. 1) are interpreted as rifted fragments of the southern part of the North Asian Craton and cratonal margin (NSC, NSV, figs. 1, 3, 7; Natal'in, 1991, 1993; Sengör and others, 1993, 1994; Sengör and Natal'in, 1996). Rifting of this collage of terranes, as well as formation of similar tectonic units in the Transbaikal region of southern Siberia and in northern Mongolia, is interpreted as occurring during the latest Proterozoic. (2) The Baladek (BL) cratonal terrane and the Paleozoic Ayansk (AY) passive-continental-margin terrane (fig. 1), on the basis of similar stratigraphy and lithology, are also interpreted as displaced fragments of the North Asian Craton and cratonal margin (NSC, NSV, figs. 1, 3, 7), respectively (Natal'in, 1991, 1993; Sengör and others, 1993, 1994; Sengör and Natal'in, 1996a, b). (3) The early Paleozoic and older Bureya continental-margin-arc terrane (BU, figs. 1, 7) and similar tectonic units in northeastern China and Inner Mongolia are interpreted as dismembered parts of the Manchurid orogenic system that formed along the northern margin of the North China Craton (Natal'in, 1991, 1993; Sengör and others, 1993, 1994; Sengör and Natal'in, 1996a, b).

Both the early Paleozoic and older Mamyn (MM, fig. 1) and Bureya (BU, figs. 1, 7) continental-margin-arc terranes are interpreted as parts of one or more continental-margin arcs that were active at various times during the Paleozoic (B.A. Natal'in, in Nokleberg and others, 1994a). The occur-

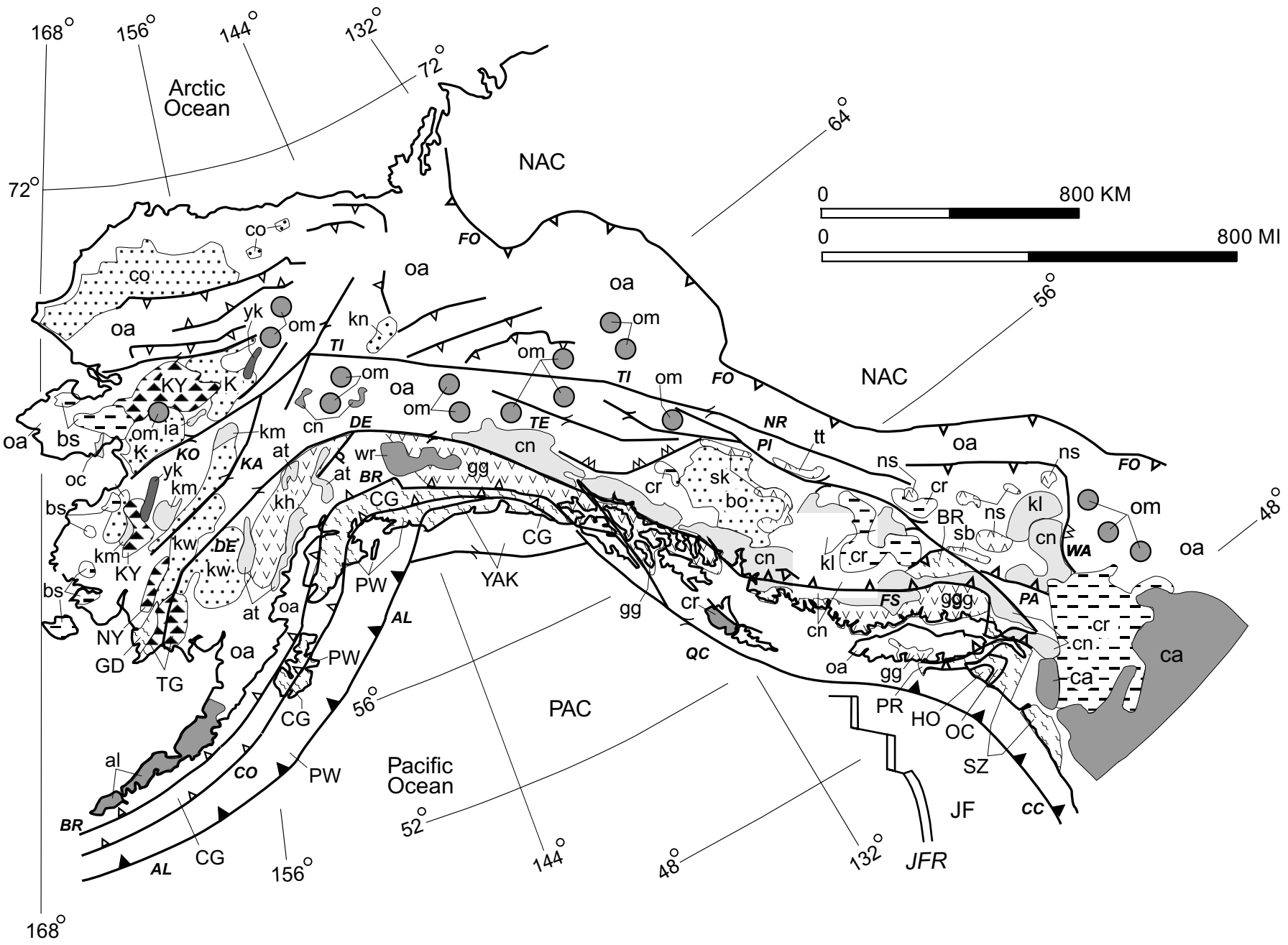

Figure 4.- Generalized map of Alaska, the Canadian Cordillera, and adjacent offshore areas, showing locations of overlap assemblages, tectonically linked subduction zones, major oceanic plates and rifts, and major faults. Adapted from Nokleberg and others (1994a, 1997a, b) and Monger and Nokleberg (1996). 
rence of large, poorly dated early and late Paleozoic granite and granodiorite intrusions in all three terranes suggests to some researchers that these terranes were part of a single arc (Parfenov, 1984; Parfenov and Natal'in, 1985; Zonenshain and others, 1990; Khanchuk, 1993; Natal'in, 1993; Sengör and Natal'in, 1996). However, differences in stratigraphy, and palinspastic reconstruction, for the Mamyn and Bureya continental-margin-arc terranes indicate that they are fragments of distinct arcs. The Mamyn continentalmargin-arc terrane and associated Gonzha (GZ) and Argun (AU) cratonal terranes, and the Oldoi (OD) passive-continental-margin terrane (fig. 1), are all interpreted as dismembered parts of the Altaid orogenic system (Natal'in, 1991,
1993; Sengör and others, 1993; Sengör and Natal'in, 1996a, b). In contrast, the Bureya continental-margin-arc terrane, which locally contains Late Proterozoic to early Paleozoic igneous-arc rocks, is interpreted as having formed along the northern part of the North China cratonal margin as part of the Manchurid orogenic system (Natal'in, 1991, 1993; Sengör and others, 1993; Sengör and Natal'in, 1996a, b). Disintegration of both the Altaid and Manchurid orogenic systems into terranes occurred mainly in the Mesozoic during the tectonic escape initiated by the convergence of the North Asian (Siberia) and North China Cratons (B.A. Natal'in, in Nokleberg and others, 1994a; Sengör and Natal'in, 1996a, b).

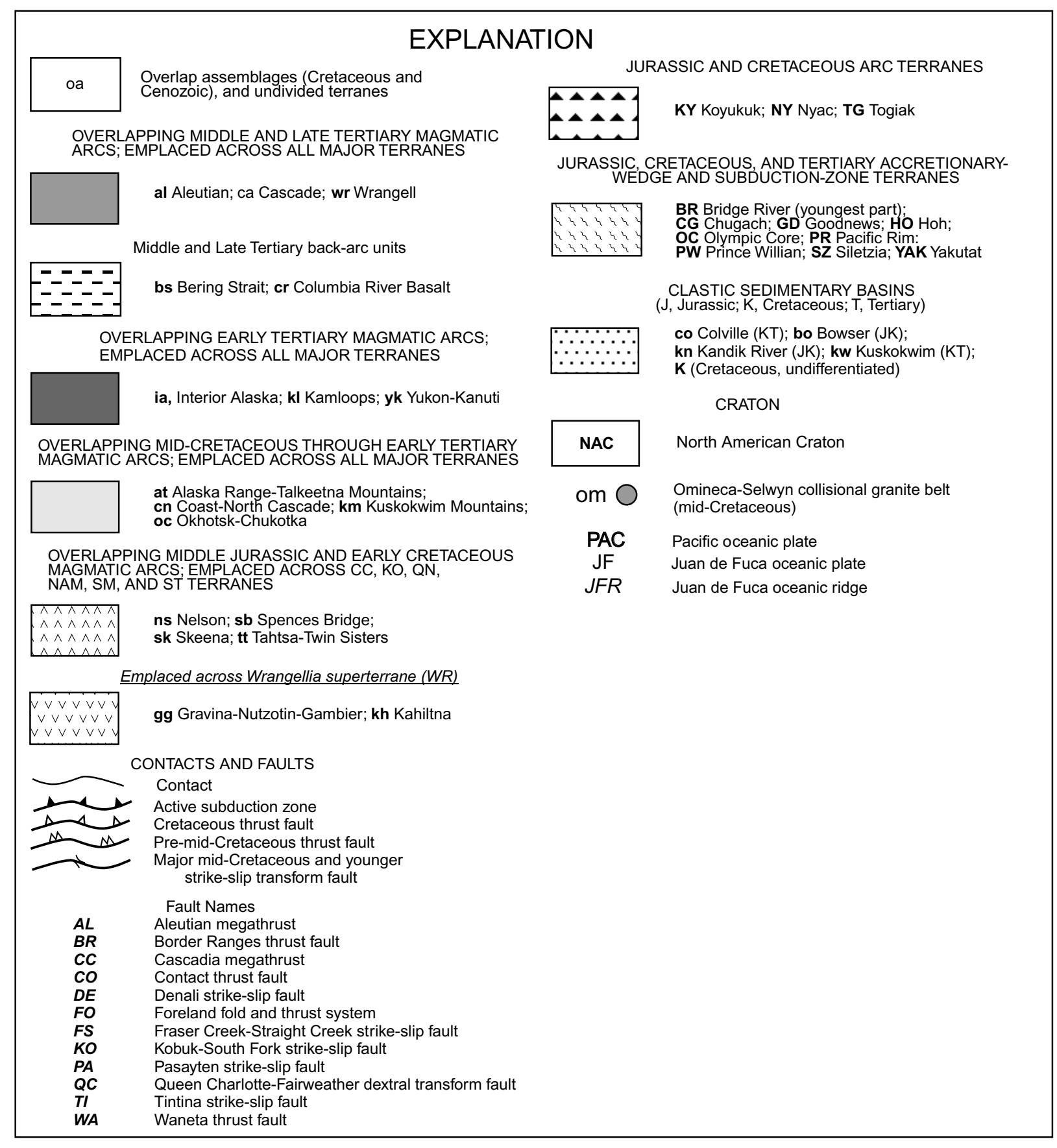




\section{Correlation of Passive-Continental-Margin Terranes in the Russian Northeast, Alaska, and the Canadian Cordillera and Linkage to the North American Craton}

Around the Circum-North Pacific, a suite of passivecontinental-margin terranes are correlated and interpreted as derived from the North American cratonal margin (NAM, figs. 2, 7). These units are the Chukotka terrane $(\mathrm{CH})$ in the Russian Northeast, the Arctic Alaska superterrane (AA) in Alaska, and the Cassiar terrane (CA) in the Canadian Cordillera (figs. $1,2,7)$.

\section{Eastern Part of the Chukotka Terrane and the Arctic Alaska Superterrane}

Stratigraphic analysis of the North Slope terrane of the Arctic Alaska superterrane (AA, figs. 1, 2, 7; approximately the equivalent of the Arctic composite terrane of Plafker and Berg, 1994), the eastern part of the Chukotka terrane (CH, figs. 1, 7; Wrangell subterrane of the Chukotka terrane; Nokleberg and others, 1994a), and the Cassiar terrane (CA, figs. 2, 7; Nokleberg and others, 1994a) reveal that these units, and adjacent passive-continental-margin terranes, constitute a long-lived Late Proterozoic, Paleozoic, and early Mesozoic, Atlantic-type passive continental margin that faced the ancestral Pacific Ocean (Monger and others, 1991a; Moore and others, 1994b). This long-lived continental margin underwent two periods of continental-margin-arc activity, one during the Late Proterozoic, currently recognized only in northern Alaska, and another during the Devonian and Mississippian, recognized in both northern Alaska and the Russian Northeast. In the Russian Northeast, the Chukotka terrane contains a Boreal fauna of Permian, Triassic, and Jurassic age (Dagis and others, 1979; Dagis and Dagis, 1984; Zakharov and others, 1984).

The regional correlation of these passive-continentalmargin terranes (Nokleberg and others, 1994a) is based on (1) regionally similar stratigraphy and (2) similar geologic positions around the Circum-North Pacific. Before the opening of the Canada Basin, these terranes were interpreted by most workers to have been part of the passive continental margin adjacent to the North American Craton (NAC, figs. 2, 4, 7; Grantz and others, 1990, 1991, 1998; Parfenov and others, 1993a, b; Monger and others, 1994; Plafker and Berg, 1994; Monger and Nokleberg, 1996; Parfenov, 1997). This grouping of terranes represents the extension of the Paleozoic North American continental margin into the Chukotka region of the Russian Northeast. The Arctic Alaska superterrane (AA, figs. $1,2,7)$ and Chukotka terrane $(\mathrm{CH}$, figs. 1,7$)$ were displaced by counterclockwise rotation, rifting, and (or) lateral translation associated with the Early Cretaceous opening of the Canada Basin (Lawver and Scotese, 1990; Grantz and others, 1991; Lane, 1994, 1997; Moore and others, 1994a). Recent detrital-zircon isotopic studies in northeastern Alaska contradict the stratigraphic correlations of Proterozoic strata required by the rotation model, but these studies are compat- ible with a transitional model involving rifting of Alaska and translation along a major transform-fault system (McClelland, 1997).

\section{Cassiar Terrane}

The Cassiar terrane (CA, figs. 2, 7) was part of the western Canadian margin that was displaced at least $450 \mathrm{~km}$ northward by dextral movement on the Tintina-Northern Rocky Mountain Trench Fault System during the Late Cretaceous and Early Tertiary (Gabrielse, 1985). The most complete rock sequences in these terranes are similar to those of the North American continental margin, namely, Late Proterozoic clastic-dominated strata, Cambrian through Devonian carbonate rock and shale, and Devonian-Mississippian to (locally) Triassic and Jurassic clastic rocks with fewer carbonates. Rare magmatic rocks include Late Proterozoic and Devonian granitic plutons and mafic and felsic volcanic-arc rocks. Northward displacement of the Cassiar terrane by more than 2,000 $\mathrm{km}$, mostly during the Permian and Triassic, from a source in present-day Idaho was suggested by Pope and Sears (1997).

\section{Correlation of Metamorphosed Continental- Margin Terranes in the Russian Northeast, Alaska, and the Canadian Cordillera and Linkage to the North American Craton}

Along the margins of the North American Cordillera and the northern part of the Russian Northeast, outboard of the passive-continental-margin terranes described above, are metamorphosed continental-margin terranes of Late Proterozoic and Paleozoic age that are linked to the North American Craton (NAC): the Seward (SD) Coldfoot (CO), Ruby (RB), Yukon-Tanana (YT), and Kootenay (KO) terranes (figs. 1, 2, $4,7)$. These terranes are correlated because of similar ages, craton-derived quartz-rich clastic sedimentary-rock units, and Late Devonian and Early Mississippian continental-marginarc sequences (Rubin and others, 1991; Nokleberg and others, 1994a). The terranes are interpreted as having been displaced by a combination of strike-slip and thrust movement from loci along the North American continental margin. They exhibit broadly similar stratigraphy, structure, metamorphism, and geographic position between inboard passive-continental-margin terranes and outboard island-arc and subduction-zone terranes (figs. 1, 2; Mortensen, 1992; Foster and others, 1994; Gehrels and Berg, 1994; Moore and others, 1994b; Patton and others, 1994; Till and Dumoulin, 1994). The Seward terrane, which occurs on both sides of the Bering Strait, forms a major link from the Russian Northeast into northwestern Alaska (figs. 1, 2). A long prong of the Yukon-Tanana terrane extends southeastward to lat $52^{\circ} \mathrm{N}$. near the Canadian Coast Mountains (fig. 2). Most of these terranes were multiply penetratively deformed and metamorphosed from the middle Paleozoic through the Mesozoic. The Yukon-Tanana terrane exhibits several periods of regional deformation and metamorphism that range in age from late Paleozoic through mid- 
Cretaceous to Late Cretaceous (Mortensen, 1992). The Late Jurassic to mid-Cretaceous events are interpreted as having occurred during accretion of outboard oceanic terranes, such as the Stikinia (ST), Quesnellia (QN), and Cache Creek (CC) terranes and the Wrangellia (WRA) superterrane (figs. 2, 7).

The metamorphosed continental-margin terranes are composed mainly of clastic-dominated successions containing mafic to felsic volcanic rocks, coeval granitic plutons, and local marble. Their protolith ages are mainly early and middle Paleozoic but locally may be as old as Late Proterozoic or as young as Triassic. Their facies, and the ages of detrital zircons from clastic deposits within them, strongly suggest that these units are distal, oceanward equivalents of continentalmargin strata (Smith and Gehrels, 1992). Devonian and Mississippian granitic plutons are widely distributed within the metamorphosed continental-margin terranes, whereas coeval volcanic successions are more restricted in occurrence. Scattered Permian granitic plutons occur locally, along with Devonian-Mississippian and Permian-Triassic plutonic rocks, and associated deformational and metamorphic events (Mortensen, 1992; Smith and Gehrels, 1992). The Devonian plutons appear to be related to coeval clastic-wedge deposits in the North American cratonal margin to the east and to local tuff horizons in Devonian carbonate rocks (Richards and others, 1994).

\section{Correlation of Part of the Taymyr Peninsular Collage with the Verkhoyansk Fold-and-Thrust Belt (North Asian Cratonal Margin)}

The Taymyr Peninsula is west of the western part of the Russian Northeast, to the west of the study area shown in figure 1. The collage in that region is described herein because it constitutes part the tectonic history of the CircumNorth Pacific. The Taymyr Peninsula consists of a collage of Late Proterozoic through Mesozoic terranes and overlap assemblages (Zonenshain and others, 1990; Vernikovskiy and others, 1998). The three major tectonic units in the region (from south to north) are as follows. (1) The Byrranga foldand-thrust belt contains Ordovician to Jurassic sedimentary rocks formed in a passive-continental-margin setting, Ordovician to middle Carboniferous carbonate-shelf deposits, Late Carboniferous to Early Permian clastic shallow-marine deposits, and Late Permian to Early Triassic continental clastic coal-bearing deposits. On the basis of similar Siberian fauna and stratigraphy, the Byrranga belt is correlated with the Verkhoyansk fold-and-thrust belt (North Asian cratonal margin; NSV, figs. 1, 3, 7). Middle Triassic to Jurassic sedimentary rocks on the eastern part of the Taymyr Peninsula consist of marine clastic rocks that are also similar to those of the Verkhoyansk fold-and-thrust belt. (2) The Central Taymyr superterrane consists of the Fadeev and Mamont cratonal terranes, the late Precambrian Kossovsk miogeoclinal (passive continental margin) terrane, and the late Precambrian Shrenk island-arc terrane. The Kossovsk and Shrenk terranes are composed of Early and Middle Riphean units. The areas of formation of the units in the Central Taymyr superterrane are unknown. All of the terranes in the superterrane are overlapped by Late Riphean to Early Carboniferous deposits, including Late Riphean to Cambrian carbonate rocks and Ordovician to Early Carboniferous deep-water black shale. (3) The Karsk continental-margin or turbidite terrane consists of Riphean to Ordovician turbidite. The area of formation of the Karsk terrane is unknown. All of the terranes of the Taymyr Peninsula collage are intruded by Permian to Triassic granite with isotopic ages of 240 to $280 \mathrm{Ma}$, which provide a minimum age of accretion of the terranes within the collage. Because it constitutes an onstrike extension, the Byrranga fold-and-thrust belt is correlated with the Verkhoyansk foldand-thrust belt.

\section{Correlation of Passive-Continental-Margin Terranes in the Russian Northeast with the Verkhoyansk Fold-and-Thrust Belt}

The Kula-Nera (KN), Omulevka (OV), Prikolyma (PR), and Viliga (VL) passive-continental-margin terranes are widely separated fragments in the central part of the Russian Northeast (figs. 1,7). These terranes are enclosed in a collage of accreted oceanic and island-arc terranes that indicate rifting and migration away from a continental margin. They share similar stratigraphy and fauna with each other and with the North Asian cratonal margin (Verkhoyansk fold-and-thrust belt; NSV, figs. 1, 3, 7), and they are interpreted by most workers as derived from the North Asian cratonal margin (Parfenov, 1984, 1991, 1995a-c; Parfenov and Natal'in, 1986, 1993a, b; Nokleberg and others, 1994a; Sengör and Natal'in, 1996a, b). The Omulevka, Prikolyma, and Viliga passive-continentalmargin terranes are also part of the Kolyma-Omolon superterrane (KLO, fig. 7). The major terranes in this superterrane are the Alazeya (AL), Aluchin (AC), Argatas (ARG), Beryozovka (BE), Khetachan (KH), Munilkan (MU), Oloy (OL), Omolon (OM), Omulevka (OV), Prikolyma (PL), Rassokha (RA), Uyandina (UY), and Yarakvaam (YM) terranes (figs. 1,7).

The North Asian cratonal margin (Verkhoyansk fold-andthrust belt; NSV, figs. 1,3,7) consists chiefly of a thick (max $20 \mathrm{~km}$ ) wedge of cratonal-margin deposits composed mainly of Carboniferous, Permian, Triassic, and Jurassic clastic rocks and marine-littoral, deltaic, and shelf deposits that prograde eastward (Natapov, 1984; Parfenov, 1984, 1985, 1987, 1991, 1994, 1995c; Prokopiev, 1989; Parfenov and Prokopiev, 1993; Parfenov and others, 1995). The fold belt was deposited on the passive margin of the North Asian Continent. Major units grade successively eastward into turbidite deposits and deepwater black shale. The fold belt contains local Middle to Late Devonian and Tournaisian rift-related sedimentary-rock units that are similar to those on the Siberian platform, as well as local Early Triassic and Early Jurassic alkalic-basalt flows and basalt dikes and sills. The northern and southern parts of the fold belt contain thick shallow-marine carbonate and clastic deposits of Late Proterozoic and early Paleozoic age that become finer grained and thicker to the east.

This Kula-Nera passive-continental-margin terrane (KN, figs. 1,7), outboard of the Verkhoyansk fold-and-thrust belt 
(North Asian cratonal margin; NSV, figs. 1, 3, 7), is juxtaposed against the fold-and-thrust belt along the AdychaTaryn Fault, which exhibits older, large-scale overthrusting and subsequent sinistral strike-slip displacements. The terrane consists (Parfenov and others, 1989; Bychkov and Kiseleva, 1990) of a thick assemblage of Permian, Triassic, and Early Jurassic hemipelagic and pelagic mudstone, siltstone, and minor sandstone and Permian and Early Jurassic radiolarian chert and tuff. The Kula-Nera terrane is interpreted as a deep-sea-fan complex interbedded with continental-rise and marginal-sea pelagic deposits that formed between the passive margin of the Siberian Continent (North Asian cratonal margin) and various parts of the Kolyma-Omolon superterrane to the east. The Kula-Nera terrane is weakly to strongly metamorphosed and deformed, exhibits lower greenschistand locally epidote-amphibolite-facies metamorphic assemblages, and is locally deformed into gently inclined appressed and superposed folds. The Kula-Nera terrane contains a Permian, Triassic, and Early Jurassic Boreal fauna (Dagis and others, 1979; Dagis and Dagis, 1984; Zakharov and others, 1984) and is interpreted as a distal part of the passive continental margin of the North Asian Craton along which the proximal part is represented by the Verkhoyansk fold-andthrust belt. Both parts of the passive continental margin were overthrust and displaced along the cratonal margin during late Mesozoic deformation (Parfenov, 1984, 1997; Zonenshain and others, 1990).

The Omulevka passive-continental-margin terrane $(\mathrm{OV}$, figs. 1,7) consists chiefly of five units (Bulgakova, 1986; Natapov and Surmilova, 1986; Parfenov, 1991, 1995c; Neustroev and others, 1993): (1) presumed late Precambrian marble, schist, and metavolcanic rocks; (2) an unconformably overlying thick $(\max 1,700 \mathrm{~m})$ unit of boulder conglomerate that contains pebbles of native and exotic rocks, whereas other units consist of marble containing Middle and Late Cambrian fossils, schist, metarhyolite, and quartzite; (3) a thick sequence of Ordovician, Silurian, Devonian, and Early Carboniferous fossiliferous carbonate rocks, including limestone, dolomite, marl, and sparse sandstone, siltstone, mudstone, and (Devonian) volcanic rocks; (4) Carboniferous and Permian fossiliferous tuff, chert, shale, limestone, siltstone, and sandstone; and (5) Triassic fossiliferous siltstone, mudstone, marl, and shaly limestone.

The Prikolyma passive-continental-margin terrane (PR, figs. 1, 7) consists chiefly of several major units (Tret'yakov, 1989; Beus and Miledin, 1990; Natapov and Shul'gina, 1991): (1) a basal unit of high-grade gneiss and schist, metamorphosed to amphibolite facies, interpreted as either late Precambrian to early Paleozoic, pre-Vendian, or early Precambrian; (2) Riphean, Vendian, and Cambrian shallowmarine clastic and carbonate rocks in the central part of the terrane; (3) Ordovician and Early Silurian shallow-marine carbonate and clastic rocks in the southwestern part of terrane; (4) Devonian and Early Carboniferous shallow-water limestone, dolomite, marl, sandstone, siltstone, and conglomerate; (5) in the central and eastern parts of the terrane, abundant Late Devonian to late Paleozoic conglomerate and a thick marine sequence of mainly thin-bedded clastic, volcaniclastic and subordinate carbonate rocks of Late Devonian to Middle Carboniferous and, locally, Early Permian age;
(6) Late Carboniferous and Early Permian rift-related alkalicbasalt flows and tuff and alkalic gabbro sills, stocks, and dikes (Chakhadanskaya Formation); and (7) Late Triassic and Early Jurassic shallow-marine shale, siltstone, sandstone, and tuff in the southwestern part of the terrane.

The Viliga passive-continental-margin terrane (VL, figs. $1,7)$ consists chiefly of a thick sequence of Carboniferous, Permian, Triassic, and Jurassic marine clastic rocks, as much as $10 \mathrm{~km}$ thick (Polubotko and others, 1977; Terekhov, 1979; Bychkov and Kiseleva, 1990). The major units are (1) Early Carboniferous sandstone and interbedded conglomerate, mafic tuff, and basalt flows; (2) Late Carboniferous to Permian sandy argillite, siltstone, sandstone, tuff, chert, basalt, and shale that gradationally overlie the older units; (3) Triassic shale, siltstone, intermediate-composition tuff, and limestone; and (4) Jurassic argillite, siltstone, intermediate-composition tuff, sandstone, and conglomerate.

\section{Derivation of Passive-Continental-Margin Terranes in West-Central Alaska from the Verkhoyansk Fold-and-Thrust Belt in the Russian Northeast}

A suite of passive-continental-margin terranes in westcentral Alaska, consisting of the Nixon Fork (NX), Dillinger (DL), and Mystic (MY) terranes (figs. 2, 7), were interpreted as subterranes of the larger Farewell terrane by Decker and others (1994) and as part of the Central composite terrane by Plafker and Berg (1994). These terranes occur within a collage of accreted oceanic and island-arc terranes, a relation that indicates rifting and migration away from a continental margin.

The Nixon Fork passive-continental-margin terrane (NX, figs. 2, 7; Palmer and others, 1983; Babcock and Blodgett, 1992; Decker and others, 1994; Patton and others, 1994; Blodgett, 1998; Fryda and Blodgett, 1998) consists of (1) Late Precambrian basement, mainly pelitic and calcareous schist with minor marble, quartzite, and felsic metavolcanic rocks; (2) unmetamorphosed sedimentary rocks of probable Late Proterozoic age that consist of interbedded sandstone, siltstone, and carbonate rocks and two dolostone units (Babcock and others, 1993); (3) Middle Cambrian limestone and chert; (4) Late Cambrian to Early Ordovician platy limestone (possibly part of the lower part of the Novi Mountain Formation); (5) Early Ordovician thick platy limestone (Novi Mountain Formation); (6) Ordovician to Middle Devonian carbonate platform rocks (Telsitna, Paradise Fork, and Whirlwind Creek Formations and the Cheeneetnuk Limestone; R.B. Blodgett, written commun., 1993); and (7) Permian, Triassic, and Cretaceous fossiliferous sedimentary rocks, mainly calcareous sandstone, siltstone, conglomerate, and sparse chert. The Late Proterozoic stratified rocks are intruded by Middle Proterozoic metagranitic rocks that yield a discordant $\mathrm{U}-\mathrm{Pb}$ zircon age of $1.27 \mathrm{Ga}$ and are capped by Late Proterozoic metavolcanic rocks that yield a discordant $\mathrm{U}-\mathrm{Pb}$ zircon age of $850 \mathrm{Ma}$. The middle Paleozoic strata grade laterally into deep-water strata equivalent to the Dillinger terrane (DL, figs. 2, 7). 
The Dillinger passive-continental-margin terrane (DL, figs. 2, 7; Bundtzen and Gilbert, 1983; Gilbert and Bundtzen, 1984; Blodgett and Clough, 1985; Decker and others, 1994; Patton and others, 1994; Churkin and Carter, 1996; Blodgett, 1998; Fryda and Blodgett, 1998) consists of (1) Cambrian and Ordovician basinal limestone, banded mudstone, and silty limestone turbidite deposits; (2) Ordovician graptolitic shale and associated(?) pillow basalt; and (3) unnamed, Late Silurian through Middle Devonian shallow-marine limestone and dolomite. The terrane is unconformably overlain by sedimentary rocks of the Cretaceous Kuskokwim Group. South of the Denali Fault (DE, fig. 4), the terrane consists chiefly of (1) Cambrian(?) to Ordovician calcareous turbidites, shale, and minor greenstone; (2) Early Ordovician to Early Silurian graptolitic black shale and chert; (3) Early to Middle Silurian laminated limestone and graptolitic black shale; (4) Middle to Late Silurian sandstone turbidite deposits and shale; and (5) Late Silurian to Early Devonian limestone, breccia, sandstone, and shale.

The Mystic passive-continental-margin terrane (MY, figs. 2, 7; Gilbert and Bundtzen, 1984; Blodgett and Gilbert, 1992; Decker and others, 1994; Patton and others, 1994; Blodgett, 1998; Fryda and Blodgett, 1998) consists of a complexly deformed, but partly coherent, long-lived stratigraphic succession of (1) Silurian massive limestone; (2) Late Devonian sandstone, shale, conglomerate, and limestone that constitute the informally named Yentna limestone of Fernette and Cleveland (1984); (3) uppermost Devonian to Pennsylvanian radiolarian chert; (4) Pennsylvanian siltstone, sandstone, and conglomerate; (5) Pennsylvanian(?) and Permian flysch, chert, argillite, and conglomerate (locally plant bearing); and (6) Triassic(?) pillow basalt and gabbro.

\section{Origin of the Nixon Fork, Dillinger, and Mystic Terranes}

Debate persists about the origin of the Nixon Fork (NX), Dillinger (DL), and Mystic (MY) passive-continental-margin terranes that occur within a collage of accreted oceanic and island-arc terranes, far removed from a cratonal margin (figs. $2,7)$. Two widely different tectonic origins have been proposed. Studies by T.K. Bundtzen (oral commun., 1994) suggest derivation from similar strata that occur in the North American cratonal margin (NAM, figs. 2, 7), in the northern part of the Canadian Cordillera. This interpretation requires tectonic transport of these terranes by several hundred kilometers on such dextral-slip faults as the Denali (DE), Kaltag (KA), Tintina (TI), and related dextral-slip faults (fig. 4). Alternatively, several recent studies reported early to middle Paleozoic fauna that are typical of taxa which occur in similar-age units in the Kolyma region, suggesting that these three terranes were rifted from the Siberian continent (North Asian cratonal margin; Blodgett and Brease, 1997; Blodgett, 1998; Dumoulin and others, 1998, 1999; Fryda and Blodgett, 1998; Blodgett and Boucot, 1999). The terranes also exhibit stratigraphy which is similar to that of the North Asian cratonal margin (NSV, figs. 1, 3,7) and are herein interpreted as being derived from that unit (Nokleberg and others, 1994a).
This interpretation requires rifting of these terranes from the North Asian cratonal margin during the Late Devonian or Mississippian or earlier, and tectonic transport by several hundred kilometers to the east (present-day coordinates).

\section{Derivation of the Kilbuck-Idono Cratonal Terrane from the North Asian Craton}

The Kilbuck-Idono cratonal terrane (KI, figs. 2, 7) occurs in western Alaska in two fault-bounded fragments, about 330 $\mathrm{km}$ apart. The terrane consists chiefly of metamorphosed diorite, tonalite, trondhjemite, and granite orthogneiss, subordinate amphibolite, and minor metasedimentary rocks (Hoare and Coonrad, 1978, 1979; Box and others, 1990, 1993; Miller and others, 1991). The metasedimentary rocks are mainly quartz-mica schist, marble, garnet amphibolite, and banded iron-formation of the informally named Kanektok metamorphic complex of Hoare and Coonrad (1979). The metaplutonic rocks yield Early Proterozoic (2.06-2.07 Ga) U-Pb zircon ages of emplacement. Nd-Sm-isotopic analyses indicate a 2.5-Ga (Archean) crustal component. The terrane was metamorphosed to amphibolite facies, with retrograde greenschistfacies metamorphism, possibly during the late Mesozoic. A southern fragment constitutes the Kilbuck terrane of Box and others $(1990,1993)$, and a northern fragment constitutes the Idono Complex of Miller and others (1991). The KilbuckIdono terrane is interpreted as a highly displaced cratonal fragment; no known correlative cratonal rocks occur in Alaska or the Canadian Cordillera (Miller and others, 1991; Box and others, 1993). The terrane is herein interpreted as derived from the closest and most similar craton, the North Asian Craton (NSC, figs. 1, 3, 7). The stratigraphy of the KilbuckIdono terrane also is broadly similar to that of older parts of the Okhotsk and Omolon cratonal terranes (described below) in the Russian Northeast, which are interpreted as derived from the North Asian Craton. In addition, both the KilbuckIdono and Omolon terranes contain similar suites of ironstone (Superior Fe) deposits (Nokleberg and others, 1996, 1997a).

\section{Derivation of the Okhotsk and Omolon Cratonal Terranes from Devonian and Older Parts of the North Asian Craton}

The Okhotsk (OK, fig. 1, 7) and Omolon (OM, fig. 1) cratonal terranes occur in the central part of the Russian Northeast, either adjacent to or as part of the Kolyma-Omolon superterrane. The Okhotsk cratonal terrane (Avchenko, 1977; Chikov, 1978; Verzkhovskaya and Krichevets, 1987; Pavlov, 1993) consists of (1) large blocks of Archean to Early Proterozoic gneiss and schist, with a $\mathrm{U}-\mathrm{Pb}$ age of $3.7 \mathrm{Ga}$, and Middle and Late Proterozoic shallow-marine clastic and carbonate rocks; (2) Early Cambrian limestone, marl, and sandstone; (3) Early Ordovician conglomerate, limestone, marl, and sandstone with macrofossils; (4) unconformably overlying Middle Devonian limestone, sandstone, shale, and conglomerate, and Late Devonian rhyolite, ignimbrite, andesite, dacite, and tuff that are interlayered with nonmarine sandstone, siltstone, and 
conglomerate; and (5) mainly nonmarine clastic rocks of Carboniferous, Permian, Late Triassic, and Early and Late Jurassic age.

The Omolon cratonal terrane (Bibikova and others, 1981; Terekhov and others, 1984; Khramov, 1986; Zhulanova, 1990; Natapov and Shul'gina, 1991) consists of (1) a poorly exposed Archean to Early Proterozoic crystalline basement metamorphosed to granulite and amphibolite facies, with $\mathrm{U}-\mathrm{Pb}$ ages of 2.8 to $3.4 \mathrm{Ga}$ and an $\mathrm{Rb}-\mathrm{Sr}$ age of $3.85 \mathrm{Ga}$; (2) unconformably overlying, gently dipping low-grade Proterozoic conglomerate, sandstone, and siltstone that grade upward into limestone, quartzite, siltstone, marl, and Vendian dolomite; (3) unconformably overlying rift-related Cambrian units that consist of nonmarine sandstone, conglomerate, siltstone, and alkalic basalt, local dolomite, limestone, sandstone, and siltstone, and widespread sills and stocks of Middle Cambrian rift-related layered gabbro in several small tectonic blocks, (4) Early and Middle Ordovician shallow-marine fossiliferous limestone, dolomite, sandstone, and conglomerate; (5) unconformably overlying, widespread, gently dipping Middle and Late Devonian and Early Mississippian calc-alkalic lava, rhyolite tuff, trachyte, trachyandesite, granitic plutonic rocks, and basalt, interlayered nonmarine sandstone, conglomerate, and siltstone, and rare shallow-marine sedimentary rocks; and (6) the unconformably overlying Korba Formation (Late Mississippian), consisting of coal-bearing siltstone that includes a basal conglomerate containing clasts and pebbles of goldbearing quartz from the Kubaka Au-Au epithermal-vein deposit (Stepanov and Shishakova, 1994). The volcanic rocks forming the upper part of unit 5 at the Kubaka Au-Ag epithermal-vein deposit exhibit an $\mathrm{Rb}-\mathrm{Sr}$ isochron age of 322 to 344 Ma (Kotlyar, 1997).

\section{Origin of the Okhotsk and Omolon Terranes}

The Okhotsk and Omolon terranes are correlated (Nokleberg and others, 1994a) on the basis of (1) similar Early Ordovician brachiopods and trilobites that also occur in the North Asian (Siberian) Craton (NSC, figs. 1, 3, 7; Oradovskaya, 1974); (2) similar Boreal faunas of Carboniferous, Permian, Triassic, and Jurassic age (Korol'kov and Korol'kova, 1974); and (3) similar suites of Devonian igneous-arc rocks (Umitbaev, 1976; Lychagin, 1978; Nokleberg and others, 1994a). The Okhotsk and Omolon terranes are interpreted as derived from the North Asian Craton because of similar Early Ordovician fauna (Oradovskaya, 1974).

\section{Correlation, Linkage, and Alignment of Late Paleozoic Through Mid-Cretaceous Island-Arc Terranes of the Wrangellia Superterrane}

\section{Sequences of the Wrangellia Superterrane}

The Wrangellia island-arc superterrane (WRA, fig. 7), which occurs in south-central and southeastern Alaska and the Canadian Cordillera, contains a long succession of four island arcs that are preserved in combinations of sequences which constitute the superterrane. The four arcs, which range in age from Devonian through mid-Cretaceous, are the Devonian Sicker, the late Paleozoic Skolai, the Late Triassic and Early Jurassic Talkeetna-Bonanza, and the Late Jurassic through mid-Cretaceous Gravina arcs (Nokleberg and others, 1994a, b). The Devonian Sicker arc, in the Alexander (AX) and Wrangellia (WR) sequences of the superterrane (figs. 2, 7), is best defined in the Wrangellia sequence on Vancouver Island, in the southern part of the Canadian Cordillera. In this region, the arc consists of the Sicker Group, which contains Late Devonian arc-related volcanic and sedimentary strata that yield a U-Pb zircon age of $367 \mathrm{Ma}$ (Sicker Group), and coeval intrusions (Muller, 1980; Parrish and McNicoll, 1992). Possibly correlative middle Paleozoic arc rocks also occur in the other sequences of the superterrane (Nokleberg and others, 1994b). Remnants of the late Paleozoic Skolai arc occur mainly in the Wrangellia sequence in the eastern part of southern Alaska (Nokleberg and others, 1994b); correlative units also occur in the Peninsular sequence on the Alaska Peninsula. Remnants of the Late Triassic and Early Jurassic Talkeetna-Bonanza arc occur mainly in the Peninsular sequence (PE) in the western part of southern Alaska, and in the Wrangellia (WR) sequence in the Canadian Cordillera (figs. 2, 7; Jones and others, 1977; Muller, 1977; Nokleberg and others, 1994a, b). Remnants of the Late Jurassic through mid-Cretaceous Gravina arc occur mainly in the Wrangellia and Alexander sequences in southeastern Alaska. In addition to the arc sequences, the Wrangellia superterrane also contains a major sequence of Late Triassic basalt and coeval gabbro dikes, sills, and small plutons in the Nikolai Greenstone and correlative units in southern Alaska and in the Karmutsen Formation and correlative units in the southern part of the Canadian Cordillera that are interpreted as having formed at a paleolatitude near the Triassic Equator (Hillhouse, 1977; Hillhouse and Grommé, 1984).

\section{Stratigraphic Succession of Late Paleozoic and Mesozoic Arcs of the Wrangellia Superterrane}

Three distinct sequences, the Alexander, Peninsular, and Wrangellia, constitute the Wrangellia superterrane and contain various combinations of Paleozoic and Mesozoic island arcs. Initial analysis of terranes in southern Alaska interpreted these three sequences as separate terranes (Jones and others, 1981), whereas a more recent study interpreted that the three sequences represent various stratigraphic levels within a large superterrane (Nokleberg and others, 1994b). The reason for the initial interpretation was that each sequence is dominated by one of the three arcs. The Alexander sequence, which occurs mostly in southeastern Alaska, is mainly an early and middle Paleozoic volcanic arc, possibly a precursor to the Sicker arc, with generally only a local expression of late Paleozoic and early Mesozoic units of the Wrangellia superterrane. The Wrangellia sequence, which occurs mainly from the eastern part of southern Alaska, through southeastern Alaska, into the southern part of the Canadian Cordillera, consists mainly of a late Paleozoic Skolai arc sequence and 
the Nikolai Greenstone, one of the backarc units for the Late Triassic and Early Jurassic Talkeetna-Bonanza arc. Similarly, the Peninsular sequence, which occurs principally in the western part of southern Alaska, consists mainly of the Late Triassic and Early Jurassic Talkeetna-Bonanza arc. Only locally does a small part of the Peninsular sequence exhibit either (1) the volcanic and sedimentary rocks of the late Paleozoic Skolai island arc and the Late Triassic rift or oceanic flood basalt that form the major part of the Wrangellia sequence, or (2) possible fragments of metamorphosed Paleozoic or older metasedimentary and metavolcanic rocks that might be the early and middle Paleozoic part of the Alexander sequence. Pre-late Paleozoic basement rocks, possibly of the Alexander sequence, also occur in the Wrangellia sequence in the eastern part of southern Alaska.

The above relations indicate that, from east to west, the Alexander, Wrangellia, and Peninsular sequences exhibit successively higher levels of a structural-stratigraphic succession. The oldest part of the succession is mainly to the east, in the predominantly early and middle Paleozoic Alexander sequence; the middle part of the succession, in the central part of the predominately late Paleozoic and early Mesozoic Wrangellia sequence; and the youngest part of the succession to the west, in the predominantly middle and late Mesozoic Peninsular sequence. Despite these relations, substantial tectonic imbrication has occurred within the Wrangellia superterrane (Plafker and others, 1989a, b; Nokleberg and others, 1994a, b). The abrupt structural termination of the TalkeetnaBonanza arc and associated plutonic rocks in the eastern part of the Peninsular sequence against the very minor occurrence of the arc in the Wrangellia sequence requires extensive post-Middle Jurassic tectonic displacement of the Wrangellia sequence relative to the Peninsular sequence. Timing of the suggested strike-slip displacement between the Peninsular and Wrangellia sequences cannot be constrained more closely than to the Late Jurassic to Late Cretaceous (Nokleberg and others, 1994b).

\section{Correlation, Linkage, and Alignment of Triassic Through Mid-Cretaceous Continental-Margin Arcs, Island Arcs, and Tectonically Paired Subduction Zones}

During the Triassic through mid-Cretaceous, 11 major igneous arcs are herein recognized around the Circum-North Pacific: (1) the Jurassic Monakin arc in the Primorski region of the Russian Southeast and the Jurassic and Cretaceous eastern China-Korean igneous arc in Korea and China, both part of the Great Hinggan arc; (2) the Jurassic and Early Cretaceous Umlekan arc in the Russian Southeast; (3) the Early Cretaceous and mid-Cretaceous Khingan arc in the Russian Southeast; (4) the Late Jurassic and Early Cretaceous Uda arc in the central part of the Russian Far East; (5) the Late Triassic to Early Cretaceous Kony-Murgal Arc in the Russian Northeast; (6) the Late Jurassic through midCretaceous Mainitskiy arc in the Russian Northeast; (7) the Late Jurassic and Early Cretaceous Uyandina arc in the Rus- sian Northeast; (8) the Late Triassic and Early Jurassic Alazeya island arc in the Russian Northeast; (9) the Late Jurassic through mid-Cretaceous Nutesyn-Koyukuk arc in the Russian Northeast and western Alaska; (10) the Late Jurassic through mid-Cretaceous Gravina arc in south-central Alaska, southeastern Alaska, and the Canadian Cordillera; and (11) the Late Triassic and Early Jurassic Talkeetna-Bonanza arc in south-central Alaska, southeastern Alaska, and the Canadian Cordillera.

\section{Middle and Late Jurassic Monakin Arc in the Russian Southeast}

The Monakin arc (too small to show in figs. 1 and 3 ) is defined as a Middle and Late Jurassic suite of igneous and associated sedimentary rocks that occur in the Russian Southeast. The arc consists chiefly of sedimentary and volcanic rocks of the Monakin volcanic-plutonic belt (mo, fig. 7) and the Umlekan-Ogodzhin volcanic-plutonic belt (uo, fig. 3) that both occur in the Russian Southeast. The Monakin volcanicplutonic belt overlies the Sergeevka terrane of the Khanka superterrane and, in the western part, consists of dacite and rhyolite flows and tuffs and continental flora-bearing clastic rocks (Oleinikov and others, 1990; Decisions of the Fourth Interdepartmental Regional Meeting on Precambrian and Phanerozoic of the Far East and Eastern Baikal Regions, 1994). In the eastern part, the arc consists of basalt, andesite, and tuff that are interlayered with shallow-marine deposits containing a bivalve-mollusk fauna.

\section{Subduction-Zone Terranes in the Russian Southeast and on Hokkaido Island, Japan, Tectonically Linked to the Jurassic Monakin Arc and Correlative Igneous Arcs in Korea and China}

Tectonically linked to the Jurassic Monakin arc in the Russian Southeast is a discontinuous collage of accretionarywedge terranes in northern Japan and the southern part of the Russian Far East. The accretionary-wedge terranes, composed mainly of Paleozoic and early Mesozoic oceanic-crustal and upper-mantle rocks and turbidite deposits, consist of the Badzhal (BD), Khabarovsk (KB), and Samarka (SMA) accretionary-wedge terranes (figs. 3, 7). These terranes also are tectonically linked to the Umlekan arc, as described below. The Badzhal, Khabarovsk, and Samarka accretionary-wedge terranes (Natal'in, 1993; Nokleberg and others, 1994a; Khanchuk and others, 1996; Sengör and Natal'in, 1996a, b) share (1) similar ages of deformation(s) and melange, formed mainly during Late Triassic through Early Cretaceous subduction; and (2) a similar tectonic position and occurrence as a series of narrow, discontinuous, long tectonic lenses outboard of the UmlekanOgodzhin volcanic-plutonic belt (uo, fig. 3) of mainly Late Jurassic and Early Cretaceous age that intrudes and overlies the Bureya continental-margin-arc terrane (BU, fig. 1).

Tectonically linked to the Jurassic and Cretaceous eastern China-Korean igneous arc in Korea and China, coeval units 
with respect to the Monakin arc, are the Taukha and Oshima terranes, which are correlated with the Hern Chichibu terrane in southeastern Japan (Kojima, 1989; Kojima and others, 1991; Natal'in and Faure, 1991; Faure and Natal'in, 1992; Mizutani and Kojima, 1992; Golozubov and Khanchuk, 1996).

The Taukha accretionary-wedge terrane (TU, figs. 1, 3, 7) in the southern part of the Russian Far East consists chiefly of an Early Cretaceous accretionary complex composed of two main units (Golozubov and Melnikov, 1986; Mikhailov and others, 1986, 1987, 1989; Khanchuk and others, 1988; Rudenko and Panasenko, 1990; Natal'in, 1991; Golozubov and others, 1992; Kemkin and Khanchuk, 1993; Golozubov and Khanchuk, 1996): (1) a western, structurally lower unit of oceanic basalt overlain by Callovian to Tithonian radiolarian chert, Berriasian siliceous mudstone, and Neocomian turbidite deposits, about 3,500 m thick, that contain ammonites and pelecypods; and (2) an eastern, structurally higher unit of turbidite and olistostrome deposits containing abundant Valanginian to Hauterivian radiolarians and a Neocomian flora. The Taukha terrane also contains tectonic inclusions of oceanic intraplate basalt and chert with limestone caps (paleoguyots), as much as several thousand meters wide and $10 \mathrm{~km}$ long, containing local Tethyan fauna. Formation of the Taukha accretionary-wedge terrane is interpreted as ending during the Hauterivian to Valanginian, with subsequent offset along transpressional sinistral strike-slip faults (Natal'in, 1991; Natal'in and Faure, 1991; Golozubov and Khanchuk, 1996).

The Oshima accretionary-wedge terrane (OS, fig. 7), which occurs on Hokkaido Island in northern Japan, consists chiefly of flysch and melange (Kato and others, 1986; Minoura, 1990; Natal'in, 1991, 1993; Natal'in and Faure, 1991). The melange is composed of blocks of basalt, limestone, chert, siliceous shale, and sandstone in a shale matrix (Matsumae, Tamdrigawa, and Kamiiso Groups). Middle Carboniferous fusulinids occur in the limestone blocks, Carboniferous to Permian radiolarians in the chert blocks, Triassic conodonts and radiolarians in the limestone and chert blocks, and Late Jurassic to Early Cretaceous radiolarians in the chert and siliceous-shale blocks. The blocks were tectonically mixed during the Late Jurassic to Early Cretaceous.

The Taukha and Oshima accretionary-wedge terranes are interpreted as parts of a Jurassic and Early Cretaceous subduction zone that formed along the East Asia margin (Taira and Tashiro, 1987; Ichikawa and others, 1990; Natal'in, 1991, 1993; Natal'in and Faure, 1991; Faure and Natal'in, 1992; B.A. Natal'in, in Nokleberg and others, 1994a). This subduction zone was tectonically paired to the Jurassic granitic rocks in Korea to the southeast (Lee, 1987; Cluzel, 1991; Cluzel and others, 1991) and to the Monakin arc in the Russian Southeast (Khanchuk and others, 1996). These Jurassic igneous granitic rocks in Korea are connected by magmatic anomalies with a Jurassic to Cretaceous volcanic-plutonic belt of southeastern China. During the Cretaceous and early Cenozoic, dextral slip on numerous Cretaceous strike-slip faults caused northward tectonic transport of these accretionary-wedge terranes with respect to the magmatic arc. The eastern China-Korean igne- ous arc and tectonically paired accretionary-wedge terranes are the continuation of the Great Hinggan arc (Natal'in, 1991, 1993; Natal'in and Faure, 1991; Faure and Natal'in, 1992; B.A. Natal'in, in Nokleberg and others, 1994a).

\section{Jurassic and Early Cretaceous Umlekan Arc in the Russian Southeast}

The Umlekan arc is defined as a Jurassic and Early Cretaceous continental-margin igneous arc in the Russian Southeast (Natal'in, 1991, 1993; Natal' in and Faure, 1991; Faure and Natal'in, 1992; Natal'in and others, 1995; Khanchuk and others, 1996). Remnants of the arc are preserved in the Umlekan-Ogodzhin volcanic-plutonic belt (uo, fig. 3) and coeval Late Jurassic and Early Cretaceous granitic plutons that overlie or intrude various terranes in the Russian Southeast and the North Asian Craton (NSC, figs. 1, 3, 7). The igneous-rock units of the arc and tectonically linked subduction units occur inland from, and parallel to, the coast of the Russian Southeast for about 1,000 km (fig. 3).

\section{Igneous- and Sedimentary-Rock Units of the Umlekan Arc}

The Umlekan-Ogodzhin volcanic-plutonic belt (uo, fig. 3; Volsky, 1983; Kozlovsky, 1988) consists chiefly of (1) Early Cretaceous sandstone, conglomerate, and mudstone containing sparse flora and freshwater fauna; (2) Early Cretaceous calc-alkalic andesite, dacite, and tuff that yield K-Ar ages of 35 to $112 \mathrm{Ma}$; and (3) Late Cretaceous alkalic basalt and rhyolite. The belt is intruded by coeval Early Cretaceous granite, granodiorite, diorite, and monzodiorite. Some granitic plutons are probably Late Jurassic or older because their detritus was shed into the Early Cretaceous part of section. The belt is deposited on the Gonzha terrane and on the Mamyn and Turan terranes of the Bureya superterrane after collision of these terranes with the Tukuringra-Dzhagdi terrane (TD, fig. 1, 3).

\section{Subduction-Zone Units Linked to the Umlekan Arc}

Tectonically paired to the Umlekan arc was a subduction zone now preserved in a discontinuous collage of subductionzone and accretionary-wedge terranes in the southern part of the Russian Far East. These terranes, composed mainly of Paleozoic and early Mesozoic oceanic-crustal and upper-mantle rocks, and turbidite deposits, consist of the Badzhal (BD), Khabarovsk (KB) (older Jurassic part), and Samarka (SMA) accretionary-wedge terranes (figs. 1, 3; Natal'in, 1993; Nokleberg and others, 1994a; Khanchuk and others, 1996; Sengör and Natal'in, 1996a, b).

The Badzhal accretionary-wedge terrane (BD, figs. 1, 3) consists chiefly of (1) Paleozoic limestone olistoliths in a clastic matrix, (2) Permian and Triassic chert lenses, (3) Late Triassic through Late Jurassic turbidite deposits, (4) chert 
and siliceous shale, and (5) small lenses of mafic volcanic rocks (Shevelev and Kuzmin, 1990; Zablotsky and others, 1990; Natal'in, 1991, 1993). The terrane is interpreted as a Triassic to Middle Jurassic accretionary-wedge complex composed of tectonically intermixed oceanic and continentalslope deposits. Limestone units, which contain Carboniferous and Permian Tethyan fauna, are interpreted as the caps to seamounts.

The Khabarovsk accretionary-wedge terrane (KB, fig. 7) consists chiefly of a Jurassic and Early Cretaceous melange, with various-size fault-bounded lenses and slices of Triassic chert, Early to Middle Jurassic siliceous shale, hemipelagic sedimentary rocks, mafic volcanic rocks, and gabbro, Late Carboniferous, Permian, and Late Triassic limestone, and schist and metasandstone of unknown age (Shevelev, 1987; Natal'in and Alekseenko, 1989; Natal'in and Zyabrev, 1989). The late Paleozoic limestone, which locally contains volcanicrock layers and Tethyan fauna, is interpreted as reef caps on seamounts.

The Samarka accretionary-wedge terrane (SMA, figs. 1, 3) consists chiefly of a Middle and Late Jurassic accretionary-wedge complex that contains tectonic sheets and lenses, olistostromes, and melange inclusions of Carboniferous and Permian reef limestone, Late Triassic pelagic limestone, interlayered Late Devonian, Carboniferous, Permian, and Triassic chert, Early Jurassic siliceous shale, and Permian and Triassic clastic marine rocks (Golozubov and Melnikov, 1986; Khanchuk and others, 1988; Vrublevsky and others, 1988; Natal'in, 1991).

\section{Origin of the Umlekan Arc}

The continental-margin Umlekan arc is interpreted as having formed from subduction of part of the ancestral Pacific oceanic plate that is now preserved as tectonically interwoven fragments of the Badzhal (BD, figs. 1, 3), Khabarovsk (KB, fig. 7) (older Jurassic part), and Samarka (SMA, figs. 1, 3) terranes. This tectonic pairing is based on (1) occurrence of the accretionary-wedge terranes outboard (oceanward) of the Umlekan arc (fig. 3); (2) formation of melange structures during the Jurassic and Early Cretaceous (Nokleberg and others, 1994a; Khanchuk and others, 1996); and (3) where not disrupted by extensive Cretaceous and early Cenozoic movement along the Central Sihote-Aline strike-slip fault, dipping of melange structures and bounding faults toward and beneath igneous-rock units of the arc. Subduction is generally interpreted as ending in the late Early Cretaceous, when extensive sinistral faulting occurred along the subduction zone (Khanchuk and others, 1996).

\section{Early and Mid-Cretaceous Khingan Arc in the Russian Southeast}

The Khingan arc is defined as an Early Cretaceous and mid-Cretaceous continental-margin igneous arc in the Russian Southeast (fig. 3; Natal'in, 1991, 1993; Natal'in and Faure, 1991; Faure and Natal'in, 1992; Natal'in and others, 1995;
Khanchuk and others, 1996). The Khingan arc consists of the Khingan-Okhotsk volcanic-plutonic belt (ko) that occurs as a chain of Early and mid-Cretaceous volcanic fields with similar age, lithology, and stratigraphy (fig. 3). The belt consists (Sukhov, 1975; Scheglov, 1984; Natal'in, 1991, 1993) of mainly Barremian to Cenomanian (mid-Cretaceous) andesite and minor basalt, with coeval gabbro, diorite, and granodiorite. The belt overlies and intrudes the Badzhal (BD), Bureya (BU), and Ulban (UL) terranes (figs. 1, 3).

Tectonically paired with the Khingan continental-margin arc was a subduction zone, now preserved in a discontinuous collage of accretionary-wedge terranes in the Russian Southeast. These terranes, composed mainly of Paleozoic and early Mesozoic oceanic-crustal and upper-mantle rocks and turbidite deposits, consist of the Amur River (AM), Khabarovsk (KB) (younger Cretaceous part), and KiselvkaManoma accretionary-wedge terranes (figs. 1, 3; Natal'in and Alexeenko, 1989; Natal'in and Zyabrev, 1989; Khanchuk and others, 1994).

The Amur River terrane (AM, figs. 1, 3) consists chiefly of abundant Cretaceous turbidite deposits (Largasinsk, Uktursk, Pionersk, and Pivansk suites) and subordinate Late Jurassic hemipelagic siliceous shale that occur in an imbricate stack of southeast-verging thrust sheets and slices (Natal'in and Aleseenko, 1989, Krasny, 1966). The Kiselvka-Manoma terrane (too small to show in figs. 1, 3) occurs in a narrow band along the northeast edge of the Amur River terrane and contains Jurassic and Early Cretaceous ribbon chert, siliceous shale, Cretaceous flysch, Jurassic basalt, and Early Jurassic limestone in an Early Cretaceous olistostrome (Filippov, 1988; Shevlyev, 1987; Natal'in, 1991; Khanchuk and others, 1994). The Khabarovsk terrane (KB) (younger, Cretaceous part; too small to show in figs. 1,3) consists of a melange with various-size fault-bounded lenses and slices of Triassic chert, Early to Middle Jurassic siliceous shale, hemipelagic sedimentary rocks, mafic volcanic rocks, and gabbro, Late Carboniferous, Permian, and Late Triassic limestone, and schist and metasandstone of unknown age (Shevelev, 1987; Natal'in and Alekseenko, 1989; Natal'in and Zyabrev, 1989). The late Paleozoic limestone, which locally contains volcanic-rock layers and a Tethyan fauna, is interpreted as reef caps on seamounts.

\section{Origin of the Khingan Arc}

The Khingan continental-margin arc (ko, fig. 3) is interpreted as having formed from oblique subduction of the ancestral Pacific oceanic plate. Fragments of this plate are interpreted as occurring in tectonically interwoven fragments of the Amur River (AM), Khabarovsk (KB) (younger Early Cretaceous part), and Kiselevka-Manoma accretionary-wedge terranes (Natal'in, 1991, 1993; Nokleberg and others, 1994a; Sengör and Natal'in, 1996a, b). This tectonic pairing is based on (1) occurrence of accretionary-wedge terranes outboard (oceanward) of, and parallel to, the various parts of the Khinghan arc (fig. 3); (2) formation of melange structures during the Early and mid-Cretaceous (Vrublevsky and others, 1988; Natal'in, 1991; Nokleberg and others, 1994a; Nechaev and 
others, 1996); and (3) where not disrupted by extensive Cretaceous movement along the Central Sihote-Aline strikeslip fault, dipping of melange structures and bounding faults toward and beneath igneous-rock units of the arc (Natal'in, 1993). Formation of the Khingan arc and associated subduction is generally interpreted as ending in the late mid-Cretaceous, when oblique subduction changed into sinistral-slip faulting along the outboard margin of the arc.

\section{Mid-Cretaceous Kema Island Arc in the Eastern Part of the Russian Southeast}

The Kema arc is defined as a suite of mainly mid-Cretaceous igneous rocks in the East Sikhote-Alin area in the Russian Southeast and offshore on Sakhalin Island (Nokleberg and others, 1994a; Khanchuk and others, 1996). These igneous-arc rocks were originally defined as part of the midCretaceous and Late Cretaceous East Sikhote-Alin continental-margin arc (es, fig. 3; Parfenov and Natal'in, 1986) or as part of the Samaka island arc (SMA, figs. 1, 3; Simanenko, 1986). However, Late Cretaceous volcanic rocks of the East Sikhote-Alin arc disconformably overlie igneous rocks of the Kema terrane, thereby indicating, along with other field relations, that the Kema arc is a separate terrane (Nazarenko and Bazhanov, 1986; Khanchuk and others, 1996).

\section{Rock Units of the Kema Arc}

The Kema island-arc terrane (KE, fig. 3) consists chiefly of a chain of predominantly volcanic rocks, with a western unit of volcaniclastic deposits. The volcanic rocks consist of lava, hyaloclastic rocks, and marine tuff and are composed of basalt, basaltic andesite, and andesite. These units occur in flows that range in thickness from a few meters to a few tens of meters. Other rocks are terrigenous volcanic deposits, flysch composed of fine-grained sandstone and siltstone, and distal turbidite-type argillite that alternates with beds of volcaniclastic rocks. Thick layers of basaltic andesite also occur. Sedimentary rocks contain Aptian to Albian bivalves. In the lower part of the section, the flysch consists of alternating, medium-grained sandstone and tuffaceous sandstone, with typical turbidite-graded bedding, and abundant siltstone fragments. The sandstone is arkosic and medium grained (Nazarenko and Bazhanov, 1986; Simanenko, 1986; Khanchuk and others, 1996).

\section{Subduction-Zone Units Related to the Kema Arc}

Tectonically linked to the Kema arc was an elongate, transpressional subduction zone that is now preserved in a discontinuous and disrupted collage of terranes in the Sakhalin and Hokkaido Islands. The terranes are the older part of the Aniva subduction-zone terrane (ANV) on Sakhalin Island and the Kamuikotan subduction-zone terrane (KK) on Hokkaido Island (figs. 1, 3). The older part of the Aniva subduc- tion-zone terrane consists chiefly of a melange unit with a matrix of mid-Cretaceous turbidite that encloses bodies of serpentinite melange, ophiolite, blueschist, and greenschist (Richter, 1986). The Kamuikotan subduction-zone terrane consists chiefly of high-pressure metamorphic rocks, serpentinite melange, and ophiolite. K-Ar ages of the ophiolite range from 100 to $125 \mathrm{Ma}$ (Kato and Nakagawa, 1986; Ichikawa and others, 1990).

\section{Origin of the Kema Arc}

The Kema arc is interpreted as having formed from subduction of part of the ancestral Pacific oceanic plate that is now preserved as tectonically interwoven fragments of the Aniva and Kamuikotan subduction-zone terranes. Volcanic rocks of the Kema arc correlate with the Early Cretaceous and mid-Cretaceous volcanic rocks that disconformably overlie the Oshima accretionary-wedge terrane on Hokkaido Island (too small to show in fig. 1) and volcanic rocks of the northeastern part of Honshu Island (Kiminami and Kontani, 1983; Ichikawa and others, 1990). The Early Cretaceous and midCretaceous Kema arc is similar to the present-day AleutianWrangell arc.

\section{Late Jurassic and Early Cretaceous Uda Arc in the Central Part of the Russian Far East}

The Uda igneous arc is defined as a suite of mainly Late Jurassic and Early Cretaceous and lesser Late Triassic to Middle Jurassic igneous-rock units in the central part of the Russian Far East (Parfenov, 1984; Parfenov and Natal'in, 1985, 1986; Natal'in, 1993; B.A. Natal'in, in Nokleberg and others, 1994a; Sengör and Natal'in, 1996a, b). Remnants of the arc are preserved in the Uda volcanic-plutonic belt (ud, fig. 3), the Uniya-Bom turbidite-basin terrane (UB, fig. 1), the Umlekan-Ogodzhin volcanic-plutonic belt (uo, fig. 3), and the Upper Amur sedimentary assemblage (ua, fig. 3). The Uda arc was deposited on, adjacent to, and intruded into the North Asian Craton (NSC), the Stanovoy block of the North Asian Craton (NSS), and the Okhotsk terrane (OK) and was formed as part of the Mongol-Okhotsk active continental margin (figs. 1, 3, 7). Farther south, magmatic equivalents of the Uda arc occur in the Great Hinggan Mountains of northeastern China (Natal'in, 1993; B.A. Natal'in, in Nokleberg and others, 1994a; Sengör and Natal'in, 1996a, b). The various igneousarc-related units of the Uda arc (Uda volcanic-plutonic belt, Uniya-Bom turbidite-basin terrane, Umlekan-Ogodzhin volcanic-plutonic belt, and Upper Amur sedimentary assemblage) are grouped into a single arc on the basis of similar age, similar arc origin, geographic proximity, and simplicity.

\section{Rock Units of the Uda Arc}

The Uda volcanic-plutonic belt (ud, fig. 3) consists chiefly of basalt, andesite-basalt, andesite, and tuff that are interlayered with nonmarine sandstone, siltstone, conglomer- 
ate, and coal containing a Late Jurassic and Early Cretaceous flora (Filatova, 1979, 1988; Sosunov and others, 1982; Lebedev and others, 1989; Zmievskiy and others, 1990). The belt also contains Jurassic granitic rocks, including granodiorite, diorite, and granite, which extend westward along the southern part of the North Asian cratonal margin (NSC, figs. 1, 3, 7). The granitic rocks of the belt yield reliable isotopic ages ranging from 130 to $200 \mathrm{Ma}$.

The Uniya-Bom turbidite-basin terrane (UB, fig. 1) consists chiefly of a tectonic sheet that is composed of Late Triassic to Early Jurassic turbidite deposits and interbedded olistostromes (Kirillova and Turbin, 1979; Natal'in and others, 1985). The turbidite deposits contain lenses of greenstone and chert that are typical of the Tukuringra-Dzhagdi terrane (TD). Sandstone and conglomerate clasts were derived in part from the North Asian Craton (NSC, figs. 1, 3, 7). The terrane is intensively deformed and contains a penetrative stretching lineation that formed by ductile deformation during strike-slip tectonic transport.

The Umlekan-Ogodzhin volcanic-plutonic belt (uo, fig. 3) consists chiefly (Volsky, 1983; Kozlovsky, 1988) of (1) Early Cretaceous sandstone, conglomerate, mudstone, calc-alkalic andesite, dacite, and tuff, with K-Ar ages of 112 to $135 \mathrm{Ma}$; (2) Late Cretaceous alkalic basalt and rhyolite; and (3) Early Cretaceous granite, granodiorite, diorite, and monzodiorite.

The Upper Amur sedimentary assemblage (ua, fig. 3) consists chiefly of Late Jurassic shallow-marine sandstone, siltstone, and shale, and nonmarine Early Cretaceous clastic rocks containing coal (Kirillova and Turbin, 1979). The structural thickness of the sedimentary rocks is about $3,000 \mathrm{~m}$.

\section{Subduction-Zone Units Linked to the Uda Arc}

Tectonically paired to the Uda continental-margin arc was a subduction zone that is now preserved in a discontinuous collage of terranes in the central part of the Russian Far East. These terranes, composed mainly of Paleozoic and early Mesozoic oceanic-crustal rocks, upper-mantle rocks, and turbidite deposits, consist of the Tukuringra-Dzhagdi subduction-zone (TD), the Galam accretionary-wedge (GL), and the Ulban accretionary-wedge (UL) terranes (fig. 3; Parfenov, 1984; Parfenov and Natal'in, 1985, 1986; Natal'in, 1991, 1993; Natal'in and Borukayev, 1991; Natal'in and Faure, 1991, Faure and Natal'in, 1992; B.A. Natal'in, in Nokleberg and others, 1994a; Khanchuk and others, 1996; Sengör and Natal'in, 1996). These subduction-zone terranes occur along splays of the Mongol-Okhotsk Fault, along which substantial middle Mesozoic through early Tertiary sinistral-slip faulting has occurred.

The Turkuringra-Dzhagdi accretionary-wedge terrane (TD, figs. 1, 3) consists chiefly of fault-bounded units of tectonic lenses or olistoliths of Late Proterozoic limestone, Silurian and Devonian mafic volcanic rocks and chert, Carboniferous and Permian sandstone, siltstone, shale, and turbidites, flysch, greenstone, chert, and limestone containing Permian Tethyan fusulinids, and a narrow tectonic lens of ophiolite (Pikansk complex) along the southern margin of the terrane that consists of gabbro, amphibolite pyroxenite, serpentinite, and plagiogranite (Natal'in and others, 1985, Kozlovsky, 1988).
The Galam accretionary-wedge terrane (GL, figs. 1, 3) consists chiefly of (1) Cambrian and Early Ordovician limestone olistoliths in a flysch matrix; (2) Silurian to Early Carboniferous and Late Permian turbidite deposits; and (3) lesser mafic volcanic rocks, chert, siliceous shale, pelagic shale, and fine-grained graywacke that are included in widespread olistostrome deposits. Oceanic chert, mafic volcanic rocks, and clastic rocks of Silurian to Late Permian age also occur in local tectonic slices (Kirillova and Makhinin, 1983; Roganov and others, 1986; Natal'in and Popeko, 1991). Along the boundary with the Baladek cratonal terrane (BL, fig. 1) are fault slices of harzburgite, dunite, and websterite.

The Ulban accretionary-wedge terrane (UL, fig. 3) consists chiefly of Early and Middle Jurassic turbidite deposits and unconformably overlying Callovian turbidite deposits (Natal'in, 1991). The turbidite deposits contain local tectonic lenses of oceanic-crustal rocks that include chert, siliceous shale, and mafic volcanic rocks.

\section{Origin of the Uda Arc}

The Uda continental-margin arc is interpreted as having formed from subduction of the Mongol-Okhotsk Ocean that is now preserved as tectonically interwoven fragments of the Turkuringra-Dzhagdi, Galam, and Ulban subduction-zone and accretionary-wedge terranes (figs. 7-15; Natal'in, 1993; B.A. Natal'in, in Nokleberg and others, 1994a; Sengör and Natal'in, 1996a, b). This tectonic pairing is based on (1) occurrence of these accretionary-wedge terranes outboard (oceanward), southward of (in present-day coordinates), and parallel to, the various parts of the Uda arc (ud, fig. 3); (2) formation of melange structures during the Jurassic and Early Cretaceous (Nokleberg and others, 1994a); and (3) where not disrupted by extensive Cretaceous and early Cenozoic dextral slip along the Mongol-Okhotsk Fault (MU, fig. 3), dipping of melange structures and bounding faults toward and beneath igneous-rock units of the arc. Subduction is generally interpreted as ending in the Early to mid-Cretaceous, during final closure of the Mongol-Okhotsk Ocean.

\section{Late Triassic to Early Cretaceous Kony-Murgal Arc in the Russian Northeast}

Remnants of the Kony-Murgal continental-margin and island arc are preserved in the Kony-Murgal island-arc terrane (KM, figs. 1, 3) in the eastern part of the Russian Northeast. The Kony-Murgal terrane occurs along the northwestern margin of the Sea of Okhotsk, southeast of the Kolyma-Omolon superterrane (fig. 1). The Kony-Murgal arc is the eastward extension of the mostly coeval Uda arc. The Kony-Murgal continental-margin and island-arc terrane consists chiefly of Late Triassic to Hauterivian folded, calc-alkaline, continental and island-arc volcanic and sedimentary rocks (Belyi, 1977; Filatova, 1979, 1988; Parfenov, 1984; Nekrasov and Sumin, 1987). The volcanic-rock units are mainly basalt, andesite-basalt, andesite, and tuff and local shallow-marine and 
nonmarine volcaniclastic rocks. The terrane also contains Late Jurassic and Early Cretaceous (pre-Albian) granodiorite, tonalite, plagiogranite, and quartz diorite and, locally, Late Permian through Middle Jurassic shale, siltstone, sandstone, conglomerate, tuff, and basalt.

\section{Subduction-Zone Units Linked to the Kony-Murgal Arc}

Tectonically linked to the Kony-Murgal arc was a subduction zone now preserved in the discontinuous collage of the Talovskiy (TL) subduction zone and Penzhina-Anadyr (PA) accretionary wedge (figs. 1, 3). These terranes, which occur outboard (oceanward) of, and parallel to, the Kony-Murgal arc (figs. 1, 2), consist mainly of Paleozoic and early Mesozoic oceanic-crustal rocks, upper-mantle rocks, and turbidite deposits (Parfenov and others, 1993a, b; Nokleberg and others, 1994a).

The Talovskiy terrane (TL, figs. 1, 3; Khanchuk and others, 1990; Sokolov, 1990, 1992; Vishnevskaya and others, 1992; Heiphitz and others, 1994b; Sokolov and Byalobzhesky, 1996; Khudoley and Sokolov, 1998) consists chiefly of (1) tectonic sheets of Bathonian and Tithonian ophiolite and serpentinite melange, with blocks of ultramafic rock, gabbro, plagiogranite, oceanic dike suites, amphibolite, and glaucophane schist; (2) island-arc and forearc andesite, dacite, tuff, and sedimentary rocks; and (3) the Kuyul subduction-zone melange, composed of Late Jurassic and Early Cretaceous turbidite deposits.

The Penzhina-Anadyr terrane (PA, figs. 1, 3; Khanchuk and others, 1992; Sokolov, 1992; Sokolov and Byalobzhesky, 1996; Khudoley and Sokolov, 1998) consists chiefly of (1) thrust slices of serpentinite melange; (2) an ophiolite sequence that is depositionally overlain by Devonian and Carboniferous chert, calcareous sandstone, tuff, and limestone; (3) younger diabase, plagiogranite, and diorite dikes with K-Ar ages of 180 to $304 \mathrm{Ma}$; (4) shallow-marine sandstone and siltstone with interlayered conglomerate; and (5) Late Jurassic to Early Cretaceous sandstone, siltstone, and mudstone.

\section{Origin of the Kony-Murgal Arc}

The Kony-Murgal arc is interpreted as having formed from subduction of part of the ancestral Pacific oceanic plate (Parfenov and Natal'in, 1985, 1986; Filatova, 1988; Zonenshain and others, 1990; Sokolov, 1992; Parfenov and others, 1993a, b; Nokleberg and others, 1994a) that is preserved in the Kony-Murgan (KM) continental-margin and island-arc, the Talovskiy (TL) subduction-zone, and the Penzhina-Anadyr (PA) accretionary-wedge and subduction-zone terranes (figs. 7-15). This tectonic pairing is based on (1) occurrence of these subduction-related terranes outboard (oceanward or to the east using present-day coordinates) and parallel to the various parts of the other rock units of the Kony-Murgal arc (fig. 1); (2) formation of melange structures during the Jurassic and Early Cretaceous (Nokleberg and others, 1994a); and (3) where not disrupted by displacement along Cretaceous and early Cenozoic northwest- striking strike-slip faults, dipping of melange structures and bounding faults toward and beneath igneous-rock units of the arc. Subduction is generally interpreted as ending in the Early Cretaceous to mid-Cretaceous during final closure of the Mongol-Okhotsk Ocean and the accretion of the KonyMurgal island arc onto the Northeast Asian continental margin (Stavsky and others, 1989, 1990; Zonenshain and others, 1990; Sokolov, 1992).

\section{Late Jurassic Through Mid-Cretaceous Pekul'ney Arc in the Russian Northeast}

Remnants of the Pekul'ney island arc are preserved in the West Pekul'ney island-arc terrane (WP, figs. 1, 3) in the eastern part of the Russian Northeast. The West Pekul'ney island-arc terrane (Nekrasov and Sumin, 1987; Zhulanova and Pertsev, 1987) consists of various tectonic sheets composed of (1) thick, folded sequences of flows and volcaniclastic rocks of intermediate, mafic, and sparse felsic compositions, argillite, siltstone, sandstone, grit, and rare limestone containing Buchia of Berriasian and Valanginian age and Aucelline of Aptian to Albian age; (2) Hauterivian to Barremian olistostrome with gabbro, ultramafic rock, jasper, and basalt fragments; (3) Early Cretaceous plagiogranite, and gabbro, amphibole-pyroxene schist, and olivine gabbro with $\mathrm{Pb}-\mathrm{Pb}$-isotopic ages of 1,200 to 2,900 Ma; and (4) layered gabbro, pyroxene-amphibole gabbro, and amphibole microgabbro of unknown age.

\section{Subduction-Zone Units Linked to the Pekul'ney Arc}

Tectonically linked to the Pekul'ney arc was a subduction zone now preserved in the discontinuous collage of the Pekul'ney subduction-zone terrane (PK) that occurs outboard (oceanward) of, and parallel to the Pekul'ney terrane (fig. 1; Parfenov and others, 1993a, b; Nokleberg and others, 1994a). The terrane (Nekrasov and Sumin, 1987; Zhulanova and Pertsev, 1987) has western and eastern units. The western unit consists of (1) a basal serpentinite-matrix melange that contains fragments of metamorphic rocks, including greenschist, glaucophane schist, and picritic basalt, (2) a metamorphic complex composed of amphibolite and schist that are derived from dunite, spinel peridotite, and clinopyroxenite that yields $\mathrm{Pb}-\mathrm{Pb}$-isotopic ages of 1.6 to $1.8 \mathrm{Ga}$, and eclogite inclusions that yield isotopic ages of 1.9 to $2.4 \mathrm{Ga}$; and (3) the Late Jurassic and Early Cretaceous Pekulneyveem suite, which is composed of basalt, tuff, hyaloclastite, radiolarian chert, siltstone, and sandstone. The eastern unit of the Pekul'ney terrane consists of the Televeem unit, which is a thick flysch of Early Cretaceous (Aptian to Albian) and Late Cretaceous (Cenomanian to Turonian) age.

\section{Origin of the Pekul'ney Arc}

The Pekul'ney arc is interpreted as having formed from subduction of part of the ancestral Pacific oceanic plate (Parfenov and Natal'in, 1985, 1986; Filatova, 1988; Zonens- 
hain and others, 1990; Sokolov, 1992; Parfenov and others, 1993a, b; Nokleberg and others, 1994a) that is preserved in the Pekul'ney subduction-zone terrane (PK). This tectonic pairing is based on (1) occurrence of the subduction-related terranes outboard or east of (in present-day coordinates), and parallel to, the West Pekul'ney terrane (fig. 1); (2) formation of melange structures during the Jurassic and Early Cretaceous (Nokleberg and others, 1994a); and (3) where not disrupted by displacement along Cretaceous and early Cenozoic northwest-striking, strike-slip faults, dipping of melange structures and bounding faults toward and beneath other units of the arc. Subduction is generally interpreted as ending in the Early to mid-Cretaceous, during accretion of the island arc onto the Northeast Asian continental margin (Stavsky and others, 1989; Zonenshain and others, 1990; Sokolov, 1992).

\section{Late Jurassic Through Middle Cretaceous Mainitskiy Arc in the Russian Northeast}

Remnants of the Mainitskiy arc are preserved in the Mainitskiy island-arc terrane (MAI, figs. 1, 3) that occurs in the eastern part of the Russian Northeast (Stavsky and others, 1989; Zonenshain and others, 1990; Bogdanov and Til'man, 1992; Sokolov, 1992; Parfenov and others, 1993a, b; Nokleberg and others, 1994a; Sokolov and Byalobzhesky, 1996). The Mainitskiy island-arc terrane consists of two sequences (Stavsky and others, 1989; Shmakin, 1991; Vishnevskaya and others, 1991; Sokolov, 1992; Didenko and others, 1993; Sokolov and Byalobzhesky, 1996). An older sequence consists of a lower unit of serpentinite and serpentinite melange that contain fragments of late Paleozoic and early Mesozoic ophiolite with Middle and Late Jurassic radiolarians, and an upper Berriasian and Valanginian unit of graywacke, siltstone, tuff, and bedded chert. Local olistoliths are common and are composed of ophiolite, limestone containing Permian and Triassic foraminifers, plagiogranite, andesite, and rhyolite. A younger sequence consists of a thick assemblage of Late Jurassic and Early Cretaceous island-arc volcanic and sedimentary rocks composed of tholeiitic basalt, andesitic basalt, rhyolite, tuff, breccia, chert, siltstone, and sandstone containing Callovian to Kimmeridgian and Tithonian to Hauterivian radiolarians. The Mainitskiy terrane also contains a complex series of large, tectonically imbricated nappes of disrupted ophiolite (Yagel melange) of Late Jurassic to Early Cretaceous (Callovian to Hauterivian) age and several tectonic sheets of dunite, harzburgite, gabbro, and ultramafic rocks that are structurally overlain by island-arc volcanic rocks. The Mainitskiy terrane is interpreted as a fragment of a Late Jurassic to mid-Cretaceous island arc that is underlain by a basement of oceanic crust and primitive-island-arc rocks of Triassic to Early Jurassic age.

\section{Subduction-Zone Units Linked to the Mainitskiy Arc}

Tectonically linked to the Mainitskiy arc was a subduction zone now preserved in the discontinuous collage of the Alkatvaam accretionary-wedge terrane (AV, figs. 1, 3; Soko- lov, 1992; Didenko and others, 1993; Parfenov and others, 1993a, b; Nokleberg and others, 1994a; Sokolov and Byalobzhesky, 1996; Khudoley and Sokolov, 1998). The Alkatvaam accretionary-wedge terrane consists chiefly of an intensely deformed, thick assemblage of clastic flysch and tuffaceous and clastic deposits, with local coeval intercalated Late Triassic, Late Jurassic, Cretaceous, and Paleocene island-arc volcanic and pyroclastic rocks (Pushcharovskiy and Til'man, 1982; Kazimirov, 1985; Grigor'yev and others, 1987). A basal unit of serpentinite melange contains fragments of late Paleozoic and Triassic ophiolite and metamorphic rocks.

\section{Origin of the Mainitskiy Arc}

The Mainitskiy arc is interpreted as having formed from subduction of part of the ancestral Pacific oceanic plate (Stavsky and others, 1989; Zonenshain and others, 1990; Sokolov, 1992; Parfenov and others, 1993a, b; Nokleberg and others, 1994a; Sokolov and Byalobzhesky, 1996) that is partly preserved in the Alkatvaam accretionary-wedge terrane (AV, fig. 3). This tectonic pairing is based on (1) the occurrence of the Alkatvaam terrane outboard of, and parallel to, the various island-arc terranes (fig. 3); and (2) coeval, Late Jurassic and Early Cretaceous accretion of the Mainitskiy and Alkatvaam terranes. Subduction is generally interpreted as ending in the mid-Cretaceous with the accretion of the Mainitskiy arc and associated subduction zone and the subsequent outboard (oceanward) stepping of subduction to form the OkhotskChukotka igneous arc (Parfenov and others, 1993a, b; Nokleberg and others, 1994a; Sokolov and Byalobzhesky, 1996).

\section{Late Jurassic and Early Cretaceous Uyandina Arc in the Russian Northeast}

The Uyandina arc is defined as the suite of igneous rocks of the Uyandina-Yasachnaya volcanic belt that forms part of the Indigirka-Oloy sedimentary-volcanic-plutonic assemblage (io, fig. 3) along the western and southwestern margins (present-day coordinates) of the Kolyma-Omolon superterrane in the central part of the Russian Far East (Parfenov, 1984, 1991, 1995a, b; Sosunov, 1985; Nokleberg and others, 1994a). The Indigirka-Oloy assemblage contains the Uyandina-Yasachnaya volcanic belt, the Zyryanka sedimentary basin, the small Ainakhkurgen, Umkuveem, and Upper Penzhina basins, and the North Omolon basin. The UyandinaYasachnaya volcanic belt occurs in the southwestern part of the Indigirka-Oloy assemblage in the Chersky Range.

\section{Rock Units of the Uyandina Arc}

The Indigirka-Oloy sedimentary-volcanic-plutonic assemblage (io, fig. 3) consists chiefly of shallow-marine and nonmarine late Middle Jurassic to Neocomian formations overlying Precambrian, Paleozoic, and early Mesozoic rocks of the Kolyma-Omolon superterrane (Parfenov, 
1984, 1991, 1995a, b; Archegov and others, 1987; Gaiduk, 1988; Gaiduk and others, 1989, 1993; Shul'gina and others, 1990). The assemblage consists of mainly sandstone, siltstone, shale, conglomerate, volcanic rocks of varying composition, and lesser granitic plutonic rocks. The assemblage is weakly deformed and is folded into large, doubly plunging anticlines and synclines. It consists of three distinct volcanic belts and sedimentary basins. (1) The Zyryanka sedimentary basin is a $60-\mathrm{km}$-wide and 550-km-long basin, in the central part of the Indigirka-Oloy assemblage, that contains Late Jurassic through Late Cretaceous marine clastic rocks. The Zyryanka basin is interpreted as having formed in the backarc region of the Uyandina-Yasachnaya arc (Parfenov, 1984, 1991, 1995a, b). (2) The small Ainakhkurgen, Umkuveem, and Upper Penzhina basins along the southeastern margin of the assemblage contain Late Jurassic and Neocomian graywacke and shale. (3) The North Omolon basin in the central part of the Kolyma-Omolon superterrane contains shallow marine and nonmarine Late Jurassic and Neocomian sandstone, shale, conglomerate, and alkalic basalt.

The Uyandina-Yasachnaya volcanic belt consists of calc-alkalic basalt, andesite, and rhyolite, interlayered with shallow-marine and nonmarine sandstone, siltstone, shale, and conglomerate of Oxfordian, Kimmeridgian, and Early Volgian age. The belt is intruded by granitic rocks with Ar-Ar and K-Ar ages of 120 to $144 \mathrm{Ma}$ (Fujita and others, 1997).

\section{Subduction-Zone Units Linked to the Uyandina Arc}

The subduction zone tectonically linked to the Uyandina arc is assumed to have been situated along the southwestern and northwestern margins of the Kolyma-Omolon superterrane (Parfenov, 1984, 1991, 1995b). Along these margins are the In'yali-Debin and Polousny synclinoria, which are composed of highly deformed Late Jurassic flysch. These deposits are interpreted as representing the forearc basin of the Uyandina arc. Near the Charky-Indigirka thrust fault, which separates the synclinoria from the Kula-Nera terrane, is the Chersky Range ophiolite belt that contains the Garbyn'ya and Debin ophiolite complexes (GB, DB, fig. 1) of unknown age (Oxman and others, 1995). These ophiolites are herein interpreted as the subducted remnants of the Oimyakon Ocean that formed between the North Asian cratonal margin and the Kolyma-Omolon superterrane (Oxman and others, 1995; Parfenov and others, 1996). The backarc basin of the Uyandina arc is interpreted northeast of the arc and is represented by Kimmeridgian and Volgian black shale of the Ilin-Tas anticlinorium and the Zyryanko basin. An alternative interpretation is that the subduction zone linked to the Uyandina arc was situated to the northeast of the arc (Zonenshain and others, 1990). With this interpretation, the black shale of the Ilin-Tas anticlinorium represent the Uyandina-Yasachnaya forearc, and the flysch deposits in the In'yali-Debin and Polousny synclinorium represent the backarc.

\section{Origin of the Uyandina Arc}

The Uyandina arc is interpreted as having formed from convergence between the Kolyma-Omolon superterrane and the North Asian cratonal margin (Verkhoyansk fold-and-thrust belt; NSV, figs. 1, 3, 7) and closing of the relatively small Oimyakon Ocean (Parfenov, 1984, 1995b, 1997). This ocean is interpreted as opening during the Late Devonian to Early Carboniferous as a result of rifting of the Omulevka terrane from the North Asian Craton. The collision of the KolymaOmolon superterrane and the North Asian Craton (Trunilina and Orlov, 1997) resulted in the formation of (1) the collisional Main batholith granite belt that extends along the southwestern margin of the superterrane, and (2) the subduction-related Northern collisional granite belt (no, fig. 3) that extends along the northwestern margin of the superterrane. ${ }^{39} \mathrm{Ar} /{ }^{40} \mathrm{Ar}$ data indicate that the Main granite belt formed at 144 to $134 \mathrm{Ma}$ and the Northern collisional granite belt at 127 to $120 \mathrm{Ma}$ (Fujita and others, 1997). These data and relations indicate that the Uyandina arc and associated subduction ended in the Early Cretaceous with accretion of the Kolyma-Omolon superterrane to the North Asian cratonal margin (NSV, figs. 1, 3, 7; Parfenov, 1991, 1995a, b, 1997; Parfenov and others, 1993a, b; Nokleberg and others, 1994a). Many of the data supporting this interpretation are derived from the northwest-southeast-trending part of the Kolyma structural loop of Zonenshain and others (1990).

\section{Late Jurassic and Early Cretaceous Oloy and Svyatov Nos Arcs in the Russian Northeast}

The Oloy and Svyatov Nos continental-margin arcs are defined as suites of igneous rocks of the Oloy and Svyatov Nos volcanic belts that occur along the eastern and northeastern margins (present-day coordinates) of the Kolyma-Omolon superterrane (KLO, fig. 7) in the central part of the Russian Northeast (Parfenov, 1984, 1991, 1995a, b; Sosunov, 1985; Nokleberg and others, 1994a). The Late Jurassic-Neocomian Oloy volcanic belt (included in the Indigirka-Oloy sedimentary-volcanic-plutonic assemblage; io, fig. 3) occurs along the northeastern margin of the Kolyma-Omolon superterrane. The belt consists of shallow-marine and nonmarine mafic, intermediate-composition, and siliceous volcanic rocks and tuff, associated sedimentary rocks, and small plutons of granite, granodiorite, and monzogranite (Shul'gina and others, 1990; Natapov and Shul'gina, 1991). The Late Jurassic Svyatov Nos volcanic belt (also included in the Indigirka-Oloy sedimentary-volcanic-plutonic assemblage; io, fig. 3) extends in a north-south direction across the Svyatov Nos Cape and, according to aeromagnetic data, can be traced northward into the eastern part of the Laptev Sea. The belt contains mainly andesite, rhyolite, and tuff, with interlayered shallow-marine sandstone, conglomerate, and siltstone.

\section{Subduction-Zone Units Linked to the Oloy and Svyatov Nos Arcs}

Tectonically linked to the Oloy and Svyatov Nos volcanic belts was a subduction zone now preserved in the South Anyui terrane (SA, fig. 3; Parfenov, 1984). The South Anyui subduction-zone terrane (Natal'in, 1984; Savostin and Drachev, 1988a, b; Dudko and Spektor, 1989; Lychagin and others, 
1991; Drachev and Savostin, 1992) consists of thrust slices of (1) tectonic sheets of serpentinized peridotite and Permian to Triassic turbidite deposits; (2) highly deformed, Carboniferous (in part) midoceanic-ridge-type pillow lavas; (3) interlayered midoceanic-ridge-type pillow basalt and Middle and Late Jurassic graywacke, slate, and chert; and (4) local glaucophane schist and Berriasian through Hauterivian turbidites.

\section{Origin of the Oloy and Svyatov Nos Arcs}

The Oloy and Svyatov Nos volcanic belts are interpreted as parts of continental-margin igneous arcs that formed during closure of different parts of the South Anyui Ocean. This tectonic pairing is based mainly on the occurrence of the South Anyui terrane outboard of, and parallel to, the newly formed continental margin of Northeast Asia and parallel to the Oloy and Svyatov Nos volcanic belts (fig. 3). Subduction is generally interpreted as occurring during the Late Jurassic and Early Cretaceous, when the arcs were active (Parfenov, 1984, 1991, 1995b; Parfenov and others, 1993a, b).

\section{Late Paleozoic to Early Jurassic Alazeya Arc in the Russian Northeast}

Remnants of the mainly Late Triassic and Early Jurassic and possibly middle and late Paleozoic Alazeya island arc are preserved in the Alazeya (AL) and Khetachan $(\mathrm{KH})$ island-arc terranes (fig. 1) in the Russian Northeast within the KolymaOmolon superterrane (fig. 3; Parfenov, 1984, 1991, 1995a, b; Sosunov, 1985; Nokleberg and others, 1994a). These terranes consist of an extensive suite of mainly Late Triassic and Early Jurassic volcanic rocks and granitic plutonic rocks that extend for a distance of only about $150 \mathrm{~km}$ (fig. 1). In addition to Late Triassic and Early Jurassic igneous-arc rocks, the Alazeya island-arc terrane also contains middle and late Paleozoic igneous-arc rocks that may correlate with the Carboniferous Skolai island arc of the Wrangellia superterrane (Nokleberg and others, 1994a).

\section{Rock Units of the Alazeya Arc}

The Alazeya island-arc terrane (AL, figs. 1, 3; Rusakov and others, 1975, 1977; Grinberg and others, 1981) consists chiefly of (1) an intensely deformed tectonic melange composed of deep-water basalt, chert, graywacke, glaucophane schist, and greenschist of unknown age; and (2) a thick sequence of Carboniferous to Early Jurassic littoral-marine and shallow-marine tuff of intermediate, mafic, and siliceous composition, graywacke, grit, and conglomerate with rare lava horizons.

The Khetachan island-arc terrane (KH, figs. 1, 3; Afitsky and Lychagin, 1987; Natapov and Shul'gina, 1991) consists chiefly of (1) strongly deformed, thick, Late Triassic to Early Jurassic volcanogenic sandstone, grit, and conglomerate and lesser mafic to intermediate-composition tuff and calc-alkalic volcanic flows, with interbedded siltstone, argillite and lime- stone; and (2) Early Jurassic siltstone, volcaniclastic sandstone and conglomerate, interbedded basaltic and andesitic tuff and flows, and Late Triassic syenite and diorite.

\section{Subduction-Zone Units Linked to the Alazeya Arc}

Tectonically linked to the Alazeya arc was probably an elongate subduction zone that is preserved only as a small remnant in the Aluchin subduction-zone terrane (AC, figs. 1, 3 ), which occurs at the east end of this chain of island-arc terranes. The Aluchin subduction-zone terrane (Lychagin and others, 1989; Byalobzhesky and others, 1990; Seslavinskiy and Ged'ko, 1990) consists chiefly of (1) dismembered ophiolites of presumed middle Paleozoic age, including harzburgite, pyroxenite, dunite, lherzolite, gabbro, plagiogranite, a mafic dike suite, basalt, and local glaucophane schist; (2) tectonic lenses of Middle Carboniferous to Early Permian island-arc clastic-tuffaceous deposits, basalt, and andesitic basalt that are intruded by diorite and tonalite; and (3) unconformably overlying Late Triassic (Norian) shallow-marine volcanic and sedimentary rocks, and Early Jurassic clastic deposits that contain pebbles of the underlying diorite and tonalite. In the inner part of the Kolyma-Omolon superterrane, the subduction zone linked to the Alazeya arc can be traced beneath Cenozoic deposits along a horseshoe-like magnetic high (Parfenov, 1991).

\section{Origin of the Alazeya Arc}

The Alazeya arc is interpreted as having formed from subduction of the Aluchin subduction-zone terrane (Parfenov, 1991, 1995a, b; Parfenov and others, 1993a, b; Nokleberg and others, 1994a). This tectonic linkage is based mainly on the occurrence of the Aluchin subduction-zone terrane parallel to the arc (fig. 1). Subduction ended in the Early to Middle Jurassic with accretion of the arc and subduction zone to other parts of the Kolyma-Omolon superterrane, including the Omolon, Prikolyma, and Omulevka terranes.

\section{Late Jurassic Through Mid-Cretaceous Nutesyn-Koyukuk Arc in the Russian Northeast and Western Alaska}

The Nutesyn-Koyukuk igneous arc is herein defined as a discontinuous suite of mainly Late Jurassic through midCretaceous igneous-rock units in the Russian Northeast and western Alaska (Parfenov and others, 1993a, b; Parfenov, 1995a, b, 1997; Nokleberg and others, 1994a, b; Plafker and Berg, 1994; Monger and Nokleberg, 1996). The arc consists of an extensive suite of mainly turbidites, volcaniclastic rocks, volcanic rocks, and plutonic rocks. From west to east (present-day coordinates), remnants of the arc are preserved in the Nutesyn (NU), Koyukuk (KY), Nyac (NY), and Togiak (TG) island-arc terranes (figs. 1-4). The various units of the Nutesyn-Koyukuk arc occur along an east-west trend for about $2,000 \mathrm{~km}$ (figs. 1, 3) and are grouped as parts of a single 
arc on the basis of similar age, similar lithologies, geographic proximity, and simplicity. The Nutesyn part of the arc is interpreted as a continental-margin arc (Parfenov and others, 1993a, b; Parfenov, 1995a, b, 1997), whereas the onstrike Koyukuk arc is interpreted by most workers as an island arc that formed near the passive continental margin of North America (Nokleberg and others, 1994a, b; Patton and others, 1994; Plafker and Berg, 1994; Monger and Nokleberg, 1996). In western Alaska, the original linear arrangement of many terranes has been extensively disrupted by Late Cretaceous and Cenozoic dextral-slip faulting along the Kobuck (KO), Kaltag (KA), and Denali (DE) Faults (fig. 4).

\section{Rock Units of the Nutesyn-Koyukuk Arc}

The Nutesyn continental-margin terrane (NU, fig. 1; Sizykh and others, 1977; Natal'in, 1984) consists chiefly of (1) a basal unit of serpentinite and serpentinized peridotite and metagabbro; and (2) an upper unit of Late Jurassic and Early Neocomian basalt, andesitic basalt, and andesite, tuff, hypabyssal dacite, rhyodacite bodies, volcaniclastic sandstone, conglomerate, and shale. Basalt and limestone containing Early Carboniferous corals occur at the base of the Late Jurassic volcanic rocks.

The Koyukuk island-arc terrane (KY, figs. 1-3) consists of northern and southern sequences (Patton, 1973; Box and Patton, 1989; Patton, 1991; Patton and others, 1994). The northern sequence, north of the Kobuck Fault, contains chiefly basalt, voluminous Early Cretaceous (Neocomian) andesite flows, tuff, breccia, conglomerate, tuffaceous graywacke, mudstone, and bioclastic limestone with fossil and isotopic ages of Late Jurassic through Early Cretaceous (Berriasian to Aptian). The southern sequence, south of the Kobuck Fault, contains (1) Middle and Late Jurassic tonalite and trondhjemite plutonic rocks that locally intrude the Angayucham terrane (AG, figs. 1-3), which in this area may form the stratigraphic basement of the Koyukuk terrane; and (2) a sequence of Late Jurassic to Early Cretaceous volcanic and related rocks that are associated with, and unconformably overlie, the tonalite and trondhjemite. The Koyukuk terrane is generally structurally underlain, and possibly locally stratigraphically underlain, by the Angayucham terrane.

The Nyac island-arc terrane (NY, fig. 2) consists chiefly of Middle and Late Jurassic andesite and basalt flows, breccia, tuff, and interbedded shallow-marine volcaniclastic rocks; and Early Cretaceous gabbroic and granitic rocks (Hoare and Coonrad, 1978; Box, 1985b, c; Box and others, 1993).

The Togiak island-arc terrane (TG, fig. 2) consists chiefly of two major sequences (Hoare and Coonrad, 1978; Box, 1985b, c; Coe and others, 1985; Box and others, 1993): (1) a lower ophiolite sequence at the southwest end of the terrane that contains Late Triassic midoceanic-ridge pillow basalt, diabase, gabbro, and ultramafic rocks; and (2) a coherent upper sequence of Early Jurassic to Early Cretaceous marine volcaniclastic sandstone, conglomerate, shale, tuffaceous chert, minor argillaceous limestone, and marine to nonmarine andesite and basalt flows, flow breccia, and tuff.
Subduction-Zone Units Linked to the NutesynKoyukuk Arc

Tectonically linked to the Nutesyn-Koyukuk arc was an elongate subduction zone that is now preserved in a discontinuous and disrupted collage of terranes in the Russian Northeast and western Alaska. The terranes are the Velmay (VE), Angayucham (AG), and Goodnews (GD) subduction-zone terranes (figs. 1, 4; Parfenov and others, 1993a, b; Nokleberg and others, 1994a, b; Plafker and Berg, 1994; Parfenov, 1995a, b, 1997; Monger and Nokleberg, 1996). These terranes occur (1) outboard of and thrust over major, partly coeval, passive continental margin, including the Chukotka terrane $(\mathrm{CH})$ and the Arctic Alaska superterrane (AA); (2) outboard of and thrust over metamorphosed continental-margin terranes, including the Seward (SD), Coldfoot (CO), and Ruby (RB) terranes (figs. 1, 3); and (3) inboard of island-arc terranes of the Nutesyn-Koyukuk arc. In western Alaska, the original linear arrangement of these terranes has been extensively disrupted by Late Cretaceous and Cenozoic dextral-slip faulting along the Kobuck (KO), Kaltag (KA), and Denali (DE) Faults (fig. 4).

The Velmay subduction-zone terrane (VE, figs. 1, 3) consists chiefly of a suite of Triassic silicic volcanogenic rocks that are composed of metamorphosed Triassic basalt, tuff, chert, siliceous and argillaceous slate, graywacke, and tectonic blocks of serpentinized harzburgite, pyroxenite, gabbro, and plagiogranite (Voevodin and others, 1978; Tynankergav and Bychkov, 1987).

The Angayucham subduction-zone terrane (AG, figs. 1-3) consists of three thrust panels (Patton and others, 1977, 1992, 1994; Jones and others, 1988; Pallister and Carlson, 1988; Pallister and others, 1989; Patton, 1992a, b). The lower thrust panel consists chiefly of phyllonite, melange, and broken sedimentary formations. The sedimentary rocks are mainly thin-bedded, quartz- and chert-rich graywacke turbidite deposits of continental derivation, chert, phyllite, and slate. The panel contains local tectonic blocks of volcanic rocks, chert, limestone turbidite, chert-pebble conglomerate, and shallow-marine clastic deposits. The middle thrust panel consists chiefly of structurally interleaved diabase, pillow basalt, tuff, chert, graywacke, argillite, minor limestone, and volcanogenic sandstone, conglomerate, and tuff. Gabbro and diabase are locally abundant. The chert ranges in age from Late Devonian to Early Jurassic. The upper thrust panel consists chiefly of serpentinized pyroxenite, harzburgite, dunite, wehrlite, cumulate gabbro, noncumulate gabbro, and diabase. The basal contact of ophiolite is locally marked by amphibolite metamorphosed at the time of structural emplacement in the Middle Jurassic (Boak and others, 1987). The upper thrust panel is interpreted as the basal part of an ophiolitic assemblage that was emplaced during Middle or Late Jurassic onto the unrelated middle thrust panel and may be the root of the Koyukuk island arc (Patton and others, 1994). Local blueschist metamorphism occurs in the Angayucham and structurally subjacent terranes, including the southern margin of the Arctic Alaska superterrane and the Coldfoot and Ruby terranes (Moore and others, 1994a, b). The blueschist-facies minerals in units beneath oceanic rocks of the Angayucham 
terrane are generally interpreted as having formed during subduction of a passive continental margin (Moore and others, 1994a, b; Plafker and Berg, 1994).

The Goodnews subduction-zone terrane (GD, fig. 2) consists chiefly of a disrupted assemblage of pillow basalt, diabase, gabbro, chert, argillite, minor limestone, volcanogenic sandstone, and ultramafic rocks (Hoare and Coonrad, 1978; Box, 1985b, c; Box and others, 1993; Patton and others, 1994). The sedimentary rocks range in age from Ordovician to Jurassic. The terrane displays prehnite-pumpellyite, greenschist, and blueschist metamorphic-mineral assemblages (Dusel-Bacon and others, 1996).

\section{Origin of the Nutesyn-Koyukuk Arc}

The Nutesyn-Koyukuk island arc is herein interpreted as having formed in response to Late Jurassic through midCretaceous subduction of the Angayucham and Goodnews oceanic plates. Remnants of these oceanic plates are now preserved in discontinuous fragments of the Velmay, Angayucham, and Goodnews subduction-zone terranes (Nokleberg and others, 1994a, b). This tectonic pairing is based on (1) occurrence of these accretionary-wedge and subduction-zone terranes adjacent and parallel to island-arc terranes (figs. 1-4), (2) formation of melange structures during the Jurassic through mid-Cretaceous, (3) formation of blueschist-facies minerals in the subduction-zone units and in structurally subjacent terranes, and (4) dipping of melange structures and bounding faults toward and beneath the Nutesyn-Koyukuk arc (Parfenov and others, 1993a, b; Nokleberg and others, 1994a, b; Plafker and Berg, 1994; Parfenov, 1995a, b, 1997; Monger and Nokleberg, 1996). Subduction is interpreted as generally ending by the mid-Cretaceous, depending on the area, with accretion and obduction of the oceanic and ophiolite terranes onto adjacent continental-margin terranes. Most of the oceanic and ophiolite terranes exhibit older periods of Jurassic and locally older (Permian) blueschist-facies metamorphism that is linked to subduction. In northern and western Alaska, many of the terranes exhibit a younger period of generally Cretaceous greenschist-facies metamorphism that some workers have linked to extension which occurred after accretion (Miller and Hudson, 1991; Moore and others, 1994b; Patton and others, 1994).

\section{Late Jurassic Through Mid-Cretaceous Gravina Arc in Southern Alaska and the Canadian Cordillera}

The Gravina igneous arc (Gravina-Chisna and Chitina arcs of Plafker and Berg, 1994) is defined as a suite of mainly Late Jurassic through mid-Cretaceous igneous-rock units in south-central and southeastern Alaska and the Canadian Cordillera (Plafker and others, 1989a, b; McClelland and others 1991, 1992a, b; Nokleberg and others, 1994a, b; Plafker and Berg, 1994; Monger and Nokleberg, 1996). The arc consists of an extensive suite of mainly turbidites, volcaniclastic rocks, volcanic rocks, and plutonic rocks. Remnants of the arc (fig. 4) are preserved in (1) the Kahiltna sedimentary and volcanic assemblage (ka) in southern Alaska; (2) the Gravina-Nutzotin-Gambier volcanic-plutonic-sedimentary belt ( $\mathrm{gg}$ ) in southcentral and southeastern Alaska and the western part of the Canadian Cordillera; and (3) the Cadwallader (CD) (younger part), Methow (MT), Izee (IZ), and Wallowa (WA) island-arc and turbidite-basin terranes, the Spences Bridge volcanic-plutonic belt (sb), and the Tahtsa-Three Sisters-François Lake magmatic assemblage (tt) in the southern part of the Canadian Cordillera (figs. 2, 4). The Gravina igneous-arc-related units (Kahiltna assemblage and Gravina-Nutzotin-Gambier belt) occur along the entire length of the Wrangellia superterrane (WRA) for about 2,400 km (fig. 4; McClelland and others, 1991, 1992a, b). In the southern part of the Canadian Cordillera, the equivalent part of the arc consists of four small terranes, the Cadwallader (CD) island-arc (younger part), Izee (IZ) turbidite-basin, Methow (MT) turbidite-basin, and Wallowa (WA) island-arc terranes that formed mostly on late Paleozoic and early Mesozoic oceanic basements, and juxtaposed with one another by the mid-Cretaceous (Monger and others, 1994; Monger and Nokleberg, 1996). The various igneous-arc-related units of the Gravina arc are grouped into a single arc on the basis of similar age, similar lithologies, and geographic proximity. The Gravina arc is generally interpreted by some workers as an island arc that formed on the Wrangellia superterrane during migration toward North America (Plafker and others, 1989a, b; Nokleberg and others, 1994a, b; Plafker and Berg, 1994a, b; Monger and Nokleberg, 1996).

\section{Rock Units of the Gravina Arc}

The Kahiltna sedimentary and volcanic assemblage (kh, fig. 4) consists chiefly of structurally disrupted, deep-marine, partly volcaniclastic graywacke, argillite, and flysch, with minor amounts of chert, limestone, conglomerate, and andesite (Bundtzen and others, 1988; Wallace and others, 1989). The assemblage is mainly Early Cretaceous but includes rocks ranging in age from Late Jurassic to early Late Cretaceous. The assemblage is interpreted to have originally stratigraphically overlain the Peninsular sequence on the Alaska Peninsula and is thrust over older rocks of the Wrangellia superterrane in the central part of the Alaska Range.

The Gravina-Nutzotin-Gambier volcanic-plutonic-sedimentary belt (gg, fig. 4) ranges in age from Middle Jurassic (approx $167 \mathrm{Ma}$ ) to Early Cretaceous (approx $110 \mathrm{Ma}$ ) (McClelland and others, 1991, 1992a, b; Monger, 1991, 1993; Wheeler and McFeely, 1991; Haeussler, 1992a, b; Woodsworth and others, 1992; Cohen and Lundberg, 1993). The belt consists mainly of argillite, graywacke, and conglomerate, with lesser andesitic and basaltic volcanic and volcaniclastic rocks, and an extensive suite of plutons in the southwestern Canadian Coast Mountains, southeastern Alaska, and in south-central Alaska. These magmatic units terminate abruptly on the coast of southwestern British Columbia near lat $48^{\circ} 50^{\prime} \mathrm{N}$. In southeastern and south-central Alaska, these volcanogenic strata were deposited in the intraarc and backarc Gravina and Nutzotin basins and in the Kahiltna basin to the west (Cohen and Lundberg, 1993; Nokleberg and others, 1994b). No direct evidence exists 
that the Gravina-Nutzotin-Gambier belt was deposited on the Yukon-Tanana (YT) and Stikinia (ST) terranes to the northeast (fig. 2; Monger and Journeay, 1994; Monger and others, 1994). A major thrust-fault system separates the GravinaNutzotin-Gambier belt from units to the east in the Canadian Cordillera (fig. 4), and petrologic studies indicate that detritus in the Gravina basin was derived almost entirely from the arc (Cohen and Lundberg, 1993). Detrital zircons within the Nutzotin part of the belt may be derived from units to the east (Gehrels and others, 1991).

The Cadwallader island-arc terrane (CD, fig. 2) consists of Permian oceanic rocks, Triassic arc rocks, and Jurassic clastic deposits (Vallier and Brooks, 1995; Rusmore, 1987).

The Izee turbidite-basin terrane (IZ, fig. 2) consists chiefly of thick, mainly flyschoid clastic sedimentary rocks and subordinate volcaniclastic rocks of Late Triassic through Middle Jurassic (Callovian) age (Brooks and Vallier, 1978; Dickinson, 1979; Silberling and others, 1984; Vallier, 1995). Local unconformities and abundant facies changes indicate a long-lasting and complex depositional basin. The Izee terrane is interpreted as a suite of forearc deposits for an island arc.

The Methow turbidite-basin terrane (MT, fig. 2) (forearc deposits) consists of Triassic basalt and associated ultramafic rocks, Jurassic arc-related clastic deposits, and Early Cretaceous forearc-basin strata.

The Wallowa island-arc terrane (WA, fig. 2; Vallier, 1977; Vallier and others, 1977; Brooks and Vallier, 1978; Dickinson and Thayer, 1978; Hillhouse and Grommé, 1982; Lund and Snee, 1988; Harbert and others, 1990; Vallier, 1995) consists chiefly of (1) Pennsylvanian tuff and sandstone; (2) an Early Permian sequence of silicic volcaniclastic rocks; (3) Permian through Late Triassic (Carnian) volcanic and volcaniclastic sedimentary rocks; (4) abundant Middle and Late Triassic (Ladinian and Carnian) island-arc tholeiites and associated rocks; (5) massive carbonate rocks and flysch of Late Triassic (Norian) and Early Jurassic age; (6) Middle and Late Jurassic alluvial-fan, braided-stream, and marine sandstone sequences that compose fault-bounded inliers; and (7) Permian and Triassic plutonic rocks. At the south end of the Canadian Cordillera, the Wallowa island-arc terrane and adjacent Baker, Izee, and Olds Ferry terranes (fig. 2) are intruded by Late Jurassic and Early Cretaceous granitic plutons that are herein interpreted as parts of the Gravina arc.

Coeval with the Kahiltna assemblage and the GravinaNutzotin-Gambier belt to the west and north are two coeval overlap arc assemblages in the southern part of the Canadian Cordillera.

The Spences Bridge volcanic-plutonic belt (sb, fig. 4; Thorkelson and Smith, 1989; Monger and others, 1994) contains (1) a lower part composed chiefly of intermediate-composition, locally felsic, calc-alkalic, continental-margin-arc volcanic and lesser plutonic rocks of mid-Cretaceous age (105 $\mathrm{Ma})$; and (2) an upper part composed of mafic andesite that may be rift related.

The Tahtsa-Three Sisters-François Lake magmatic assemblage (tt, fig. 4) consists chiefly of Middle and Late Jurassic and Cretaceous plutonic rocks (Wheeler and
McFeely, 1991; van der Heyden, 1992; Woodsworth and others, 1992; Monger and others, 1994). The occurrence of coeval volcanic and plutonic rocks of the Spences Bridge volcanic-plutonic belt and the Tahtsa-Three Sisters-François Lake magmatic assemblage in the southern part of the Canadian Cordillera (fig. 4) in an area of previously accreted terranes suggests that the Late Jurassic to mid-Cretaceous Gravina arc associated with the Kahiltna assemblage and Gravina-Nutzotin-Gambier belt extended onto the North American Continent in this area.

\section{Subduction-Zone Units Linked to the Gravina Arc}

Tectonically linked to the Gravina arc was an elongate subduction zone that is now preserved in a discontinuous and disrupted collage of terranes in southern Alaska and the western part of the Canadian Cordillera. These terranes, mainly of Late Triassic, Jurassic, and Early Cretaceous age, are the Chugach (CG), Pacific Rim (PR), Bridge River (BR), and Baker (BA) accretionary-wedge and subduction-zone terranes (figs. 2, 4). These terranes (Nokleberg and others, 1994a; Plafker and Berg, 1994; Monger and Nokleberg, 1996) exhibit (1) rare tectonic lenses of mainly limestone with Tethyan faunas, (2) similar ages of deformation(s) that are generally interpreted as occurring during mainly Middle Jurassic to Early Cretaceous subduction (Plafker and others, 1989a, b, 1994; Plafker and Berg, 1994; Monger and Nokleberg, 1996), and (3) local blueschist-facies metamorphism.

The Chugach accretionary-wedge and subduction-zone terrane (CG, figs. 2, 4) consists of a compound, complexly deformed accretionary-wedge and subduction-zone complex of Late Triassic to Late Cretaceous melange, flysch, and oceanic rocks (Nokleberg and others, 1994a; Plafker and Berg, 1994; Kusky and others, 1997; Kusky and Bradley, 1999). The major units of the Chugach terrane (Plafker and others, 1989a, b, 1994) are (1) a northern boundary unit of blueschist dated as mainly Late Triassic to Early Jurassic; (2) the McHugh Complex, a Late Triassic through midCretaceous melange composed mainly of argillite, chert, basalt, graywacke, and melange, with rare limestone blocks containing Permian Tethyan fusulinids; and (3) the Valdez Group, an accretionary complex composed mainly of Late Cretaceous graywacke and argillite. The terrane forms a long, narrow belt that extends for several thousand kilometers along the south rim of Alaska (figs. 2, 4). The eastern part of the Chugach terrane in southern Alaska contains a large zone of upper-amphibolite-facies metamorphic rocks and associated anatectic granitic rocks of early Tertiary age (Plafker and others, 1989a, b, 1994; Plafker and Berg, 1994). This zone is interpreted as having formed during underplating of part of the Kula-Farallon oceanic ridge under the Chugach terrane during the Eocene (Plafker and others, 1989a, b; Sisson and others, 1989; Harris and others, 1996).

The Pacific Rim accretionary-wedge and subductionzone terrane (PR, figs. 2, 4) consists of Late Triassic to Early Jurassic arc-related volcanic rocks and unconformably 
overlying disrupted graywacke, argillite, conglomerate, chert, and tuff of mainly Late Jurassic (late Kimmeridgian and early Tithonian) to Early Cretaceous (mid-Valanginian) age (Muller, 1977; Brandon, 1989).

The Bridge River accretionary-wedge and subductionzone terrane (BR, figs. 2, 4) consists of disrupted Mississippian to early Late Jurassic chert, pelite, basalt, ultramafic rocks, and rare Triassic blueschist. These units are gradationally overlain by a clastic succession whose upper parts are Early Cretaceous. Rocks in the Northwestern U.S. Cascade Range that may be correlative with the younger part of the Bridge River terrane contain Jurassic and Cretaceous blueschist (Garver, 1992; Journeay and Northcote, 1992; Cordey and Schiarizza, 1993; Mahoney and Journeay, 1993; F. Cordey, written commun., 1994; Monger and others, 1994).

The Baker accretionary-wedge terrane (BA, fig. 2) consists chiefly of disrupted late Paleozoic and Triassic oceanic and island-arc volcanic and plutonic rocks and deep-marine sedimentary rocks (Burnt River Schist, Mine Ridge Schist, Elkhorn Ridge Argillite, and Nelson Marble) and melange with serpentinite matrix and tectonic blocks (Vallier, 1977, 1994; Vallier and others, 1977).

\section{Origin of the Gravina Arc}

The Gravina island arc is interpreted as having formed during Late Jurassic through mid-Cretaceous subduction of the Farallon oceanic plate along the margin of the Wrangellia superterrane and outboard of the Cadwallader and Methow terranes to the south (fig. 3). This oceanic plate is now preserved in discontinuous fragments in the younger parts of the Chugach, Bridge River, and Baker terranes and in the Pacific Rim terrane (Plafker and others, 1989a, b; Nokleberg and others, 1994a, b; Plafker and Berg, 1994; Monger and Nokleberg, 1996). This tectonic pairing is based on (1) occurrence of these accretionary-wedge and subduction-zone terranes outboard (oceanward), southward (in Alaska) or westward (in the Canadian Cordillera) (in present-day coordinates), and parallel to the various parts of the arc (figs. 2, 4); (2) formation of melange structures during the Jurassic through mid-Cretaceous; and (3) where not disrupted by Late Cretaceous and Cenozoic dextral slip along the Denali Fault (DE) and companion faults (fig. 4), dipping of melange structures and bounding faults toward and beneath igneous-rock units of the arc. Subduction is generally interpreted as ending in the Late Jurassic to mid-Cretaceous when the Wrangellia superterrane was accreted to the North American continental margin.

\section{Late Triassic and Early Jurassic Talkeetna- Bonanza Arc in Southern Alaska and the Canadian Cordillera}

The Talkeetna-Bonanza arc occurs discontinuously in southern Alaska and the Canadian Cordillera (Plafker and others, 1989a, b; Nokleberg and others, 1994a, b; Plafker and
Berg, 1994; Monger and Nokleberg, 1996). The arc consists mainly of an extensive suite of volcanic rocks, volcaniclastic rocks, turbidites, and plutonic rocks. Remnants of the arc (figs. 2, 4) are preserved in (1) the Peninsular sequence of the Wrangellia superterrane (WRA) in southwestern Alaska, (2) the Bonanza Volcanics in the Canadian Cordillera (part of an overlap assemblage on the Wrangellia superterrane), and (3) older parts of the Cadwallader island-arc (CD) and Methow turbidite-basin (MT) terranes (fig. 2). The various igneousarc-related units of the Talkeetna-Bonanza arc are grouped into a single arc on the basis of similar age, similar arc origin, geographic proximity, and simplicity. The Talkeetna-Bonanza arc is interpreted by most workers as an island arc that formed on the Wrangellia superterrane during migration toward North America (Plafker and others, 1989a, b; Nokleberg and others, 1994a, b; Plafker and Berg, 1994; Monger and Nokleberg, 1996).

\section{Rock Units of the Late Triassic and Early Jurassic Talkeetna-Bonanza Arc}

In southwestern Alaska, the Peninsular sequence (PE, fig. 2; western part of the Wrangellia superterrane in Alaska) consists mainly of an areally extensive Jurassic island-arc volcanic and plutonic sequence, which constitutes the Talkeetna arc, and younger sedimentary-rock units (Jones and others, 1981; Pavlis, 1983; Plafker and others, 1989a, b; Nokleberg and others, 1994a, b; Detterman and others, 1996). The volcanic part of the Talkeetna arc consists mainly of Late Triassic (Norian) and Early Jurassic andesitic flows, breccia, and volcaniclastic siltstone and sandstone of the Talkeetna Formation. The plutonic part of the Talkeetna arc consists of Jurassic batholithic granitic rocks. Overlying the volcanic-rock units are Middle Jurassic to Cretaceous arc-derived clastic rocks (Shelikof and Chinitna Formations, Tuxedni Group, and Kialagvik, Naknek, Staniukovich, and Herendeen Formations), and bioclastic limestone with Boreal fauna (Nelchina Limestone). Unconformably overlying units are Cretaceous to early Tertiary progradational marine and nonmarine sandstone, shale, and minor conglomerate (Matanuska, Hoodoo, Chignik, and Kaguyak Formations). The southern part of the Peninsular sequence, adjacent to the Denali Fault (DE, fig. 4), consists of the Early Jurassic Border Ranges ultramafic-mafic assemblage (BRUMA), which is interpreted as the mafic and ultramafic roots of the Talkeetna arc (Burns, 1985; DeBari and Coleman, 1989; Plafker and others, 1989a, b).

In the Canadian Cordillera, the Bonanza Formation (southeastern part of the Wrangellia superterrane) consists of Early Jurassic volcanic-arc rocks and Middle Jurassic arc rocks composed of volcanic-rock units ranging in composition from basalt to andesite and interlayered with mainly fine grained clastic rocks and intruded by the coeval Island intrusions. These units extend into the Canadian Coast Mountains to the east and are equivalent to the Bowen Island Group and the Harrison Lake Volcanics (Monger and Journeay, 1994). In the region are coeval Early and Middle Jurassic granitic intrusions (Grantz and others, 1991; Monger, 1991; Parrish and McNicoll, 1992; van der Heyden, 1992). 
The Cadwallader island-arc terrane and the Methow turbidite-basin terrane, also interpreted as part of the TalkeetnaBonanza arc, are described in the subsection above on the Gravina arc.

\section{Subduction-Zone Units Linked to the Talkeetna- Bonanza Arc}

Tectonically linked to the Talkeetna-Bonanza arc was the older part of an elongate subduction zone that is now preserved in a discontinuous and disrupted collage in southern Alaska and the western part of the Canadian Cordillera. These terranes, mainly of Late Triassic, Jurassic, and Cretaceous age, consist of the Chugach (CG), Bridge River (BR), and Baker (BA) accretionary-wedge and subduction-zone terranes (fig. 2). Descriptions of these terranes and the basis for correlating them are given in the subsection above on the Gravina arc. The Permian Tethyan faunas, which occur mainly in shallow-water carbonate rocks locally in the inner part of the Chugach terrane (McHugh Complex), are obviously exotic faunas and are generally interpreted as derived from the late Paleozoic and early Mesozoic Tethys Sea now preserved in various units in the Mediterranean region, the Middle East, the Himalayas, Southeast Asia, eastern China, the Russian Southeast, and Japan (Monger and Ross, 1971; Monger and others, 1972; Stevens and others, 1997).

\section{Backarc Sequences Linked to the Talkeetna- Bonanza Arc}

Two major sequences of Late Triassic tholeiitic pillow basalt and associated units form distinctive parts of the Wrangellia superterrane. In south-central Alaska, the Nikolai Greenstone constitutes a major unit of Late Triassic (Norian) subaerial and marine tholeiitic pillow basalt and lesser argillite and associated mafic intrusions that is thousands of meters thick; and in southeastern Alaska, a similar thick sequence of Late Triassic basalt and rhyolite, part of a bimodal suite, is present (Nokleberg and others, 1994b). On Vancouver Island, in the coastal southern part of the Canadian Cordillera, the Karmutsen Formation (too small to show in fig. 4) constitutes a coeval and distinctive Middle(?) to Late Triassic tholeiitic basalt with associated mafic intrusions. The units are interpreted as major backarc sequences with respect to the coeval Talkeetna-Bonanza arc (Barker and others, 1989; Nokleberg and others, 1994b; Plafker and Berg, 1994; Monger and Nokleberg, 1996). Alternatively, the mafic magmatism may have formed in a short-lived mantle-plume setting similar to that in Java in the South Pacific (Richards and others, 1991; Lassiter and others, 1995).

\section{Origin of the Talkeetna-Bonanza Arc}

The Talkeetna-Bonanza arc is interpreted as having formed from the Late Triassic and Early Jurassic subduction of part of the Cache Creek oceanic plate along the margin of the Wrangellia superterrane, and along the geographically adjacent Cadwallader and Methow terranes. This plate is now preserved in discontinuous fragments in the older parts of the Chugach, Bridge River, and Baker terranes (Plafker and others, 1989a, b; Nokleberg and others, 1994a, b; Plafker and Berg, 1994; Monger and Nokleberg, 1996). The younger parts of these terranes are also tectonically paired to the Gravina arc discussed above. This tectonic pairing is based on (1) occurrence of these accretionary-wedge and subduction-zone terranes outboard (oceanward) of, and parallel to, various parts of the arc (fig. 2); (2) formation of melange structures during the Late Triassic through Early Jurassic; and (3) where not disrupted by Late Cretaceous and Cenozoic dextral slip along the Denali Fault (DE) and companion faults (fig. 4), dipping of melange structures and bounding faults toward and beneath igneous-rock units of the arc. Subduction is generally interpreted as ending in the mid-Cretaceous, when a major change in the direction of sea-floor spreading occurred.

\section{Late Triassic and Early Jurassic Stikinia- Quesnellia Island Arc in East-Central Alaska and the Canadian Cordillera}

Remnants of the Stikinia-Quesnellia island arc are preserved in the Stikinia (ST) and Quesnellia (QN) terranes in east-central Alaska and in the Canadian Cordillera (fig. 2; Plafker and Berg, 1994; Mihalynuk and others, 1994; Monger and others, 1994; Monger and Nokleberg, 1996). These terranes consist of an extensive suite of mainly Late Triassic and Early Jurassic volcanic and granitic plutonic rocks, each extending for a distance of about 1,200 km (fig. 2). They occur on opposite limbs of an apparent oroclinal warp that also includes, in a complex map pattern, the Yukon-Tanana (YT) and Cache Creek (CC) terranes (fig. 2). In the core of the warp is the Cache Creek subduction-zone terrane. In successive sheaths toward the northwest are (fig. 2) (1) the Stikinia and Quesnellia island-arc terranes, (2) the YukonTanana metamorphosed continental-margin terrane, and (3) the Slide Mountain (SM) and Seventymile (SV) accretionarywedge and subduction-zone terranes. These relations were interpreted by Mihalynuk and others (1994) as the result of counterclockwise rotation during the Late Triassic and Early Jurassic of the Stikinia and Yukon-Tanana terranes to oroclinally entrap the Cache Creek terrane.

\section{Rock Units of the Stikinia-Quesnellia Arc}

The Stikinia island-arc terrane (ST, fig. 2; Monger and Ross, 1971; Monger, 1977; Monger and Irving, 1980; Monger and others, 1982; Symons, 1983a, b; Wernicke and Klepacki, 1988; Anderson, 1989; Gehrels and others, 1990; Vandal and Palmer, 1990; Evenchick, 1991; Gabrielse, 1991; Nelson and Mihalynuk, 1993) consists chiefly of (1) Early Devonian, Mississippian, Late Pennsylvanian, and Permian volcanic-arc rocks (Stikine assemblage) that are interbedded with carbonate and fine-grained clastic rocks (Brown and others, 1991); (2) unconformably overlying Late Triassic volcanic-arc rocks 
and interfingering clastic rocks (Stuhini Formation and Takla Group) and coeval granitic rocks; and (3) unconformably overlying Early Jurassic andesitic volcanic rocks and intercalated sedimentary rocks (Hazelton and Spatzizi Groups and Takwahoni Formation; Tipper and Richards, 1976; Monger, 1977; Anderson, 1989; Gabrielse, 1991). The basement of the Stikinia terrane is unknown. Suggestions have been made that it is underlain by metamorphosed continental-margin strata of the Yukon-Tanana terrane (Gehrels and others, 1990; McClelland, 1992). The Stikinia terrane is herein interpreted as occurring most probably stratigraphically, rather than structurally, above the Yukon-Tanana terrane. With this stratigraphic interpretation, the Stikinia terrane is interpreted as a fragment of an extensive early Mesozoic island arc that formed on rifted continental-margin fragments of the YukonTanana and Kootenay(?) terranes, similar to the setting of modern-day volcanic arcs of New Zealand and Japan. Ndisotopic studies from late Paleozoic through Jurassic units of the Stikinia terrane suggest a juvenile composition for the igneous rocks (Sampson and others, 1991).

The Quesnellia island-arc terrane (QN, fig. 2) consists chiefly of west-facing Late Triassic to Early Jurassic (Carnian to Sinemurian) volcanic-arc rocks (Nicola Group, Rossland Formation), coeval calc-alkalic and alkalic plutons, and laterally equivalent clastic sedimentary rocks (Mortimer, 1987; Monger, 1989; Andrew and others, 1990; Monger and others, 1994). In the southwestern part of the Canadian Cordillera, the volcanic-arc rocks are unconformably overlain by clastic rocks of the Pliensbachian to Callovian Ashcroft Formation. The early Mesozoic volcanic-arc rocks overlie at least two basement complexes (Monger and Berg, 1987): (1) Devonian through Permian chert, clastic rock, basalt, and ultramafic rocks of the oceanic Apex Mountain Complex and, probably, units of the Slide Mountain terrane; and (2) and coeval volcaniclastic rocks, pelite, and carbonate of the arc-related Harper Ranch Group. These Paleozoic strata were deformed and juxtaposed with one another and, possibly, with parts of the Kootenay terrane before the Late Triassic (Read and Okulitch, 1977; Klepacki, 1983; Orchard and Danner, 1991).

\section{Subduction-Zone Units Linked to the Stikinia- Quesnellia Arc}

Tectonically linked to the Stikinia-Quesnellia arc was a subduction zone now preserved in the discontinuous collage of the Cache Creek accretionary-wedge and subduction-zone terrane (CC), the Slide Mountain accretionary-wedge terrane (SM), and the Seventymile subduction-zone terrane (SV, fig. 2). These terranes consist mainly of a complex assemblage of Mississippian through Triassic mafic and ultramafic rocks, chert, shale, turbidite deposits, and volcanic-arc rocks.

The Cache Creek accretionary-wedge and subductionzone terrane (CC, fig. 2), which ranges in age from Early Mississippian to Early Jurassic, consists of disrupted chert, pelite, basalt, ultramafic rocks, and local volcaniclastic rocks of arc origin, as well as distinctive large bodies of Late Mississippian to Triassic reefoidal limestone containing exotic Permian
Tethyan fauna (Monger, 1977; Travers, 1978; Monger and Irving, 1980; Ross and Ross, 1983; Monger, 1985; Cordey and others, 1987, 1991; Mortimer, 1987; Gabrielse, 1991; Nelson and Mihalynuk, 1993; Monger and others, 1994). The carbonate rocks consist of distinctive large bodies of upper Paleozoic or Triassic reefoidal rocks that at least locally overlie volcanic rocks. The Late Triassic volcaniclastic rocks are of probable arc origin; in one locality, associated pelitic rocks are possibly as young as Pliensbachian (Early Jurassic); and, to the south, the unit may be as young as Middle Jurassic (Monger, 1977; Cordey and others, 1987, 1991). Late Triassic blueschist occurs locally in these terranes and in similar rocks in northern California to the south (Nokleberg and others, 1994a; Monger and others, 1996). The occurrence of Permian Tethyan fauna in the Cache Creek terrane is similar to that in other parts of the Circum-North Pacific, including the Turkuringra-Dzgadi, Badzhal, Khabarovsk, and inner Chugach (McHugh Complex) terranes. This fauna occurs mostly in detached, shallow-water, tropical-origin limestone blocks in melange. In places, the limestone blocks cap volcanic seamounts (guyots).

The Slide Mountain accretionary-wedge terrane (SM, fig. 2) consists chiefly of Late Devonian to Permian oceanic rocks but also contains structurally intermixed subordinate volcanicarc rocks, granitic rocks, and minor continent-derived clastic rocks (Struik and Orchard, 1985; Harms and others, 1988; Nelson and Bradford, 1989; Mortensen, 1992a; Richards and others, 1993; Roback and others, 1994). Substantial lithologic variation occurs within the terrane. To the south, in central and northern British Columbia, Canada, the Slide Mountain terrane consists of numerous fault-bound slices, each composed of one or several rock types, including chert, pelitic rocks, basalt, diorite, gabbro, and ultramafic rocks, with minor volcanic-arc and carbonate rocks (Struik and Orchard, 1985; Harms and others, 1988; Nelson and Bradford, 1989). Rarely can the stratigraphy be correlated between tectonic slices. Permian and Devonian to Carboniferous granitic rocks (Mortensen, 1992a) locally cut bounding faults. To the north, continent-derived clastic rocks are structurally imbricated within the Slide Mountain terrane and are possible lateral equivalents to late Paleozoic mafic volcanic rocks in the Kootenay terrane to the east (Klepacki, 1983; Roback and others, 1994). Permian plutons in the Yukon-Tanana terrane (Mortensen, 1992a, b) crosscut thrust faults in the Slide Mountain terrane (Harms, 1986; Nelson, 1993), indicating late Paleozoic juxtaposition of at least parts of the YukonTanana and Slide Mountain terranes.

The Seventymile subduction-zone terrane (SV, fig. 2) occurs as scattered remnants of three highly deformed and locally folded thrust sheets and several smaller klippen that structurally overlie the Yukon-Tanana and Stikinia(?) terranes in east-central Alaska (Keith and others, 1981; Foster and others, 1994). The lower thrust sheet, interpreted as a fragment of an island arc, is composed chiefly of a structural melange of undated metasandstone, metagraywacke, metaconglomerate, and meta-andesite. The middle thrust sheet is composed chiefly of a structural melange of pillow basalt, basalt, mafic tuff, chert, argillite, and limestone of Missis- 
sippian, Permian, and Late Triassic age; rare glaucophane occurs in pillow basalt. The middle thrust sheet is interpreted as a subduction-zone melange composed of oceanic crust and seamounts. The upper thrust sheet is composed chiefly of harzburgite and peridotite, with minor clinopyroxenite, as well as gabbro and diabase with a local amphibolite sole. It is interpreted as the possible root to part of the Jurassic(?) Stikinia island arc.

\section{Origin of the Stikinia-Quesnellia Arc}

The Stikinia-Quesnellia arc is interpreted as having formed during the Pennsylvanian, Permian, Late Triassic, and Early Jurassic subduction of part of the Cache Creek oceanic plate along one margin of the Stikinia and Quesnellia terranes, and from the Early Jurassic subduction of the Slide Mountain and Seventymile oceanic plates along the other margin of the Stikinia and Quesnellia terranes (Mihalynuk and others, 1994; Plafker and Berg, 1994; Monger and Nokleberg, 1996). These oceanic plates are now preserved in discontinuous fragments in the Cache Creek, Slide Mountain, and Seventymile terranes (Plafker and others, 1989a, b; Nokleberg and others, 1994a, b; Plafker and Berg, 1994; Monger and Nokleberg, 1996). This tectonic pairing is based on (1) occurrence of these accretionary-wedge and subduction-zone terranes adjacent and parallel to the various parts of the arc, as reconstructed in our tectonic model; and (2) formation of melange structures during the Late Triassic through Early Jurassic. Subduction is generally interpreted as ending in the Middle Jurassic when the Stikinia, Quesnellia, Cache Creek, Slide Mountain, and Seventymile terranes were obducted onto the accretionary margin of the Canadian Cordillera and onto the North American cratonal margin (NAM, figs. 2, 7; Mihalynuk and others, 1994; Plafker and Berg, 1994; Monger and Nokleberg, 1996).

\section{Correlation, Linkage, and Alignment of Late Cretaceous and Early Cenozoic Continental- Margin Arcs, Island Arcs, and Tectonically Paired Subduction Zones}

After the mid-Cretaceous, much of the Circum-North Pacific was uplifted, along with the formation of a series of continental-margin arcs and tectonically paired subduction zones. These arcs and subduction zones are the immediate ancestors of the current continental-margin arcs and subduction zones that ring the Pacific Ocean. Thus, from the Late Cretaceous onward, the major tectonic units of the region are more readily recognized and interpreted.

During the Late Jurassic to early Cenozoic, four major igneous arcs formed that are herein recognized around the Circum-North Pacific: the East Sikhote-Alin arc in the Russian Southeast, the Okhotsk-Chukotka arc in the Russian Northeast, the Olyutorka arc in the Russian Far East, and the Kluane and Coast arcs in southern Alaska and the Canadian Cordillera (figs. 3, 4).

\section{Cretaceous and Early Tertiary East Sikhote-Alin Arc in the Russian Southeast}

The East Sikhote-Alin arc is defined as a extensive suite of Late Cretaceous and early Tertiary volcanic and plutonic rocks in the Russian Southeast along the present-day continental margin. Remnants of the arc are preserved in the East Sikhote-Alin (es) volcanic-plutonic belt and in the SorachiYezo (SY) and West Sakhalin (WSA) turbidite-basin terranes (figs. 1, 3; Natal'in, 1993; B.A. Natal'in and A.I. Khanchuk, in Nokleberg and others, 1994a; Khanchuk and others, 1996; Sengör and Natal'in, 1996). These three igneous-arc-related units form a major continental-margin-arc sequence that occurs along the entire length of the Russian Southeast for about 1,250 km (fig. 3). The various igneous-arc-related units of the East Sikhote-Alin arc (East Sikhote-Alin volcanicplutonic belt and Sorachi-Yezo and West Sakhalin turbiditebasin terranes) are grouped into a single arc on the basis of similar age, similar arc origin, geographic proximity, and simplicity. Both the Sorachi-Yezo and West Sakhalin turbiditebasin terranes are interpreted as forearc-basin units for the East Sikhote-Alin arc.

\section{Rock Units of the East Sikhote-Alin Arc}

The East Sikhote-Alin volcanic-plutonic belt (es, fig. 3; Nazarenko and Bazhanov, 1986; Nevolina and Sokarev, 1986) consists chiefly of (1) Cenomanian rhyolite, dacite, basalt, and andesite; (2) thick Turonian to Santonian ignimbrite; (3) Maastrichtian to Danian basalt, andesite, and rhyolite; and (4) coeval, mainly intermediate-composition granitic plutons.

The Sorachi-Yezo turbidite-basin terrane (SY, fig. 1) in northern Japan (Kato and others, 1986) consists chiefly of (1) an ocean-floor basement assemblage of Tithonian to Barremian and Early Cretaceous basalt, chert, siliceous shale, shale, sandstone, and limestone; (2) an overlying forearc-basin assemblage of Aptian to Maastrichtian siltstone, sandstone, conglomerate, and volcaniclastic rocks, with deep-marine turbidites; (3) shallow-marine siltstone and sandstone; and (4) Aptian to Maastrichtian shallow-marine sandstone and conglomerate.

The West Sakhalin turbidite-basin terrane (WSA, fig. 1) on Sakhalin Island and Japan consists chiefly of a basal sequence of Early Cretaceous volcanic rock, jasper, and pelagic rocks and an upper sequence of Late Cretaceous clastic and tuffaceous clastic rocks (Parfenov, 1984; Zyabrev, 1984; Nevolina and Sokarev, 1986; Rozhdestvensky, 1987).

\section{Subduction-Zone Units Linked to the East Sikhote- Alin Arc}

Tectonically linked to the East Sikhote-Alin arc was a subduction zone now preserved in a discontinuous collage of terranes in the Russian Southeast and northern Japan. These terranes, composed mainly of Paleozoic and early Mesozoic oceanic-crustal and upper-mantle rocks and turbidite deposits, 
consist of the older part of the Hidaka accretionary-wedge terrane (HI), the younger part of the Aniva (ANV) subduction-zone terrane, and the Nabilsky (NAB) and Tokoro (TO) subduction-zone terranes (figs. 1, 3; Khanchuk and others, 1988; Khanchuk, 1993; Natal'in, 1993; Nokleberg and others, 1994a; Sengör and Natal'in, 1996).

The Hidaka accretionary-wedge terrane (HI, figs. 1, 3) consists chiefly of flysch and melange of the Hidaka Group that includes blocks of basalt, chert, limestone, siliceous shale, and sandstone within a shale matrix (Iwata and Tajika, 1986; Kato and others, 1986; Sakai and Kanie, 1986). The basalt occurs both as blocks in melange and as lava flows within a sedimentary succession. The Hidaka Group contains Permian fusulinids and corals, Late Triassic sponge spicules in limestone, Late Jurassic to Early Cretaceous radiolarians in chert, Early Cretaceous nannofossils in limestone, and Early Cretaceous to Eocene radiolarians in shale. The southwestern part of the Hidaka terrane includes high-temperature, lowpressure metamorphic rocks, metamorphosed from granulite to greenschist facies. The metamorphic rocks include a metamorphosed ophiolite succession that ranges from basal tectonites to an upper-level dike complex.

The Aniva subduction-zone terrane (ANV, fig. 3) consists chiefly of (1) a melange composed of lenses of Middle Triassic, Jurassic, and Early Cretaceous oceanic Ti-rich tholeiite, alkalic basalt, and chert; (2) fragments of guyots with late Paleozoic and Late Triassic limestone caps; (3) local exotic bodies of intensely metamorphosed ultramafic and mafic rocks; and (4) a matrix of Albian to Cenomanian turbidite and olistostromes (Dobretsov, 1978; Rikhter, 1986; Khanchuk and others, 1988; Bekhtold and Semenov, 1990). The terrane is complexly folded and faulted and is metamorphosed to transitional blueschist-greenschist facies.

The Nabilsky subduction-zone terrane (NAB, figs. 1, 3) consists chiefly of a melange unit with a matrix of late Campanian to early Paleogene(?) turbidites and Campanian chert olistostromes that enclose bodies of Late Jurassic and Early Cretaceous radiolarian chert and basalt, and guyot fragments (Geology of the U.S.S.R., 1970; Rikhter, 1986; Khanchuk and others, 1988). The guyots are capped by Late Jurassic to Early Cretaceous limestone that contains Tethyan reef corals. The melange also locally contains ophiolitic fragments that include large harzburgite and lherzolite bodies, sparse cumulate gabbro, sheeted dikes, and midoceanic-ridge-type seamount basalt.

The Tokoro subduction-zone terrane (TO, figs. 1, 3) consists chiefly of ultramafic cumulate rocks, diabase, pillow basalt, trachyte, alkali rhyolite, volcaniclastic rocks, chert, and limestone of Jurassic and Cretaceous age (Koji Wakita, in Nokleberg and others, 1994a).

\section{Origin of the East Sikhote-Alin Arc}

The East Sikhote-Alin continental-margin arc is interpreted as having formed from subduction of part of the ancestral Pacific Ocean plate that is now preserved as tectonically interwoven fragments of the Hidaka, Aniva, and Nabil- sky accretionary-wedge and subduction-zone terranes (fig. 4; Khanchuk and others, 1988, 1996; Zonenshain and others, 1990; Natal'in, 1993; Rozhdestvensky, 1993; B.A. Natal'in and A.I. Khanchuk, in Nokleberg and others, 1994a; Sengör and Natal'in, 1996). This tectonic pairing (Parfenov, 1984, 1991; Khanchuk and others, 1988; Natal'in, 1991, 1993; Parfenov and others, 1993a, b; Nokleberg and others, 1994a) is based on (1) occurrence of these accretionary-wedge terranes outboard from (oceanward of), southward of (in present-day coordinates), and parallel to the various parts of the East Sikhote-Alin arc (fig. 3); (2) formation of melange structures and blueschist-facies metamorphism during the Late Cretaceous and early Tertiary (Nokleberg and others, 1994a); and (3) where not disrupted by extensive early Cenozoic slip along the Central Sikhote-Alin and companion faults, dipping of melange structures and bounding faults toward and beneath igneous-rock units of the arc. Subduction is generally interpreted as ending in the early Tertiary with strike-slip dismemberment of the Russian Southeast and subsequent outboard (oceanward) stepping of subduction to form the East Japan and Kuril igneous arcs.

\section{Cretaceous and Early Tertiary Okhotsk- Chukotka Arc in the Russian Northeast}

The Okhotsk-Chukotka arc is defined as an extensive suite of partly coeval Cretaceous and early Tertiary volcanic and plutonic rocks along the continental margin in the Russian Northeast. Remnants of the arc are preserved in the OkhotskChukotka volcanic-plutonic belt (oc, figs. 3, 4, 7) and the Penzhina sedimentary basin (pn, fig. 7) and in a series of Late Cretaceous and early Tertiary granitic plutons in western Alaska (Belyi, 1977, 1978; Parfenov, 1984, 1991, 1995a, b; Parfenov and Natal'in, 1985; Sosunov, 1985; Filatova, 1988; Stavsky and others, 1989, 1990; Zonenshain and others, 1990; Bogdanov and Til'man, 1992; Sokolov, 1992; Nokleberg and others, 1994a; Sokolov and Byalobzhesky, 1996). These three units of igneous-arc-related rocks constitute a major continental-margin-arc sequence that occurs for about $3,500 \mathrm{~km}$ along the entire length of the Russia Northeast into western Alaska. The Okhotsk-Chukotka arc was deposited on, or intruded, the North Asian Craton (NSC), the North Asian cratonal margin (NSV), the Kolyma-Omolon superterrane (KLO), the Chukotka terrane, the Seward terrane, and many adjacent, smaller terranes (figs. 1, 3, 7). The various igneous-arc-related units of the Okhotsk-Chukotka arc (Okhotsk-Chukotka volcanicplutonic belt and Penzhina sedimentary basin) are grouped into a single arc on the basis of similar age, similar arc origin, geographic proximity, and simplicity. The Penzhina sedimentary basin is interpreted as a forearc-basin unit for the arc.

\section{Rock Units of the Okhotsk-Chukotka Arc}

The Okhotsk-Chukotka volcanic-plutonic belt (oc, figs. 3, 4, 7) consists of Early Cretaceous and Late Cretaceous, 
locally Paleocene gently dipping basalt, andesite-basalt, andesite, dacite, rhyolite, tuff, and rare beds of nonmarine clastic rocks, with conglomerate, grit, and sandstone at the base. Silicic volcanic rocks (mainly ignimbrites) are locally widespread (Bakharev, 1976; Belyi, 1977, 1978; Zagruzina, 1977; Parfenov, 1984; Filatova, 1988; Lebedev and others, 1989).

The Penzhina sedimentary basin (pn, fig. 7) consists chiefly of Albian to Late Cretaceous littoral-marine rocks, nonmarine clastic rocks, and coal in a northeast-striking trough, about $90 \mathrm{~km}$ wide by $500 \mathrm{~km}$ long (Parfenov, 1984). The clastic rocks consist chiefly of volcanic and polymictic sandstone, conglomerate, siltstone, argillite, and local tuff containing mollusks and plant fossils.

\section{Subduction-Zone Units Linked to the Okhotsk- Chukotka Arc}

Tectonically linked to the Okhotsk-Chukotka arc was a subduction zone now preserved in a discontinuous collage of terranes in the Russian Northeast. These terranes are the West Kamchatka (WK), Ekonay (EK), and Yanranay (YN) accretionary-wedge terranes (figs. 1, 3, 7; Khanchuk and others, 1990; Sokolov, 1990, 1992; Parfenov and others, 1993a, b; Nokleberg and others, 1994b; Sokolov and Byalobzhesky, 1996; Khudoley and Sokolov, 1998). The West Kamchatka, Ekonay, and Yanranay terranes are extensively overlapped by the West Kamchatka sedimentary basin (wk) and the Central Kamchatka (kc) and the East Kamchatka volcanic belts (ek) (fig. 7).

The West Kamchatka accretionary-wedge terrane (WK, fig. 7) consists chiefly of intensely deformed pillow and massive basalt interlayered with siliceous and carbonate rocks, and tuff of Jurassic and Early Cretaceous age; turbidite deposits (mainly graywacke, arkose, and lesser subarkose) of Late Cretaceous (Santonian to Maastrichtian) and early Paleogene age; and local olistostrome layers (Shantser and others, 1985; Bondarenko and Sokolkov, 1990; Sokolov, 1990, 1992). The terrane generally is complexly folded and imbricately thrusted.

The Ekonay accretionary-wedge terrane (EK, fig. 1, 3, 7; Byalobzhesky and others, 1986; Bychkov and others, 1990; Sokolov, 1990; Didenko and others, 1993) consists chiefly of (1) serpentinized ultramafic rocks, layered gabbro, and ultramafic rocks and leucocratic gabbro, gabbro-diabase, diabase, and plagiogranite; and (2) an upper Paleozoic to Triassic volcanic-sedimentary assemblage (spilite, basalt, and rare andesite and plagiorhyolite; various tuffaceous, cherty biogenic tuffaceous, and clastic rocks; subordinate carbonate and clastic rocks, argillite, and volcaniclastic siltstone and sandstone) that includes tectonic fragments of Carboniferous to Triassic units containing Tethyan foraminifers, radiolarians, and conodonts.

The Yanranay accretionary-wedge terrane (YN, fig. 7; Byalobzhesky and others, 1986; Grigor'yev and others, 1987; Sokolov, 1992) consists chiefly of (1) Late Jurassic and Cretaceous (as young as Campanian) midoceanic-ridge- type basalt, pelagic sedimentary rocks, chert, rare carbonate rocks, and a condensed section of radiolarite and jasper containing Tithonian, Berriasian, and Valanginian radiolarians; and (2) Early and Late Cretaceous argillite, siltstone, sandstone, and associated rocks. A local Senonian olistostrome is composed of fragments of Paleozoic to early Mesozoic and Late Jurassic to Early Cretaceous sedimentary and volcanic rocks in a siltstone matrix. The terrane is exposed in tectonic windows beneath the Ekonay terrane and is highly deformed into folds, thrusts, imbricated fault slices, and duplex structures.

\section{Origin of the Okhotsk-Chukotka Arc}

The continental-margin Okhotsk-Chukotka igneous arc is interpreted as having formed from subduction of part of the ancestral Pacific oceanic plate that is now preserved as the West Kamchatka, Ekonay, and Yanranay accretionary-wedge terranes (fig. 3). This tectonic pairing (Parfenov, 1984, 1991; Parfenov and Natal'in, 1985; Filatova, 1988; Stavsky and others, 1989; Zonenshain and others, 1990; Parfenov and others, 1993a, b; Nokleberg and others, 1994a) is based on (1) occurrence of these accretionary-wedge terranes outboard (oceanward), southward of (in present-day coordinates), and parallel to the various parts of the Okhotsk-Chukotka arc (fig. 3); (2) formation of melange structures during the Late Cretaceous and early Tertiary (Nokleberg and others, 1994a); and (3) where not disrupted by extensive early Cenozoic slip along northwest-striking faults (fig. 3), dipping of melange structures and bounding faults toward and beneath igneousrock units of the arc. Subduction is generally interpreted as ending in the early Tertiary with accretion of the Kula oceanic plate and subsequent outboard (oceanward) stepping of subduction to form the Kuril and Kamchatka igneous arcs (Scholl and others, 1992, 1994).

The units of the Okhotsk-Chukotka arc, the OkhotskChukotka volcanic-plutonic belt and Penzhina sedimentary basin and related units, are interpreted by most workers as various parts of a long continental-margin arc that was active during the Cretaceous and early Tertiary along the eastern margin of the Russian Northeast and western Alaska (Parfenov and others, 1978; Parfenov and Natal'in, 1985; Stavsky and others, 1990; Zonenshain and others, 1990; Parfenov, 1991, 1994; Bogdanov and Til'man, 1992; Parfenov and others, 1993a, b; Nokleberg and others, 1994a). The arc overlaps the previously accreted Kolyma-Omolon superterrane and adjacent terranes in the Russian Northeast and previously accreted terranes in western Alaska (figs. 3, 4).

\section{Late Cretaceous and Early Tertiary Olyutorka Arc in the Russian Far East}

Remnants of the Late Cretaceous and early Tertiary Olyutorka arc are preserved, from north to south, in the Olyutorka-Kamchatka (OKA), Iruneisky (IR), Kronotskiy (KRO), Shmidt (SH), Terpeniya (TR), and Nemuro (NE) island-arc terranes in the central and southern parts of the Russian Far East (figs. 3, 7; Rikhter, 1986; Tsukanov, 1991; Sokolov, 
1992; Zinkevich and Tsukanov, 1992, 1993; Nokleberg and others, 1994a; Sokolov and Byalobzhesky, 1996). These terranes constitute an extensive suite of coeval Late Cretaceous and early Tertiary island-arc volcanic and related rocks for about 2,700 km on the Kamchatka Peninsula, the southern Kuril Islands, and Sakhalin Island (figs. 1, 3).

\section{Rock Units of the Olyutorka Arc}

The Olyutorka-Kamchatka island-arc terrane (OKA, figs. 3, 7; Zinkevich and others, 1990, 1993; Tsukanov, 1991; Kovalenko, 1992; Zinkevich and Tsukanov, 1992, 1993; Heiphitz and others, 1994a; Brandon and others, 1997, 1998; Ramthun and others, 1997; Garver and others, 1998; Solo'ev and others, 1998; Konstantinovskaya, 1999) consists of (1) a local unit of serpentinite melange composed of blocks of mid-Cretaceous jasper, basalt, gabbro, and ultramafic rock; (2) late Campanian to early Maastrichtian island-arc deposits (Hapitskiy Complex) composed of basalt, andesite flows and tuff, tuffaceous siltstone, volcaniclastic sandstone, and tuffaceous jasper; and (3) an upper part of Maastrichtian to Paleocene volcaniclastic island-arc deposits. The terrane is locally intruded by zoned intrusive rocks ranging in composition from dunite and clinopyroxenite to gabbro (Kepezhinskas and others, 1993).

The Iruneisky island-arc terrane (IR, figs. 3, 7) consists chiefly of several tectonic sheets and overlying Cretaceous clastic deposits (Shantser and others, 1985; Zinkevich and Tsukanov, 1992, 1993): (1) pillow basalt, siliceous shale, tuff, and jasper of Albian to Cenomanian age, with structurally overlying Late Cretaceous tuff and jasper and coarse-grained mafic and intermediate-composition volcanic breccia; and (2) fine-grained silicic tuffaceous deposits, coarse-grained clastic tuffaceous deposits with Late Cretaceous basalt, and overlying tuff breccia and calc-alkalic volcanic rocks with tuffaceous sedimentary lenses that grade into Maastrichtian siliceous siltstone.

The Kronotskiy island-arc terrane (KRO, figs. 3, 7) consists chiefly Coniacian to early Paleocene island-arc basalt, lava and tuff breccia that contains hyaloclastite fragments of mafic and silicic volcanic rocks in a coarse-grained tuff, and chert (Mys Kamenistyi Complex and Kronotskaya Suite; Khubunaya, 1981; Tsukanov, 1991; Bazhenov and others, 1992). Also locally occurring is a serpentinite melange containing ophiolite fragments.

The Shmidt island-arc terrane (SH, fig. 7; Geology of the U.S.S.R., 1970; Raznitsin, 1982; Yurkova, 1991) consists chiefly of three units. (1) A lower unit of serpentinite melange, interpreted as a subduction-zone complex, is composed of harzburgite, cumulate gabbro, high-Ti mafic dikes, basalt, and Late Jurassic to Early Cretaceous radiolarian chert (Tominskia sequence). (2) An intermediate-composition unit consists of bimodal sheeted dikes and flows, siliceous tuff that yields midCretaceous (Albian to Cenomanian) radiolarians, and plagiogranite. The bimodal igneous rocks are geochemically similar to those of primitive island arcs. (3) An upper unit consists of basalt, andesite, tuff, argillite, and sandstone that yield Cenomanian to Santonian Inoceramus (Slavyansk sequence).
The Terpeniya island-arc terrane (TR, fig. 7) consists chiefly of a thick tectonic melange composed of deep-marine and terrestrial Santonian to Campanian volcanic and sedimentary rocks (Berozovskaya, Rakitinskaya, and Bogatinskaya sequences; Geology of the U.S.S.R., 1970; Khanchuk and others, 1988). The volcanic rocks consist of island-arc tholeiitic, calc-alkalic, and shoshonitic rocks. Abundant peridotitepyroxenite-gabbroic and gabbro-plagiogranite intrusions are interpreted as the magmatic part of the island arc. The terrane is structurally disrupted and strongly folded.

The Nemuro island-arc terrane (NE, figs. 3, 7) consists chiefly of two subterranes (Parfenov and others, 1983; Grapes, 1986; Kato and others, 1986; Okada and others, 1989; Golionko, 1992; Bazhenov and Burtman, 1996). (1) A northern subterrane is composed of a monoclinal sequence of conglomerate, breccia, grit, sandstone, massive calc-alkalic pillow basalt, andesitic basalt, and basalt agglomerate and tuff. The basaltic rocks contain Campanian Inoceramus and yield a K-Ar age of $88 \mathrm{Ma}$. The basaltic rocks are unconformably overlain by tuffaceous flysch with layers of alkalic pillow basalt, diabase, and shoshonite sills that yield K-Ar ages of 65 to $89 \mathrm{Ma}$ and that contain Campanian to Maastrichtian Inoceramus. (2) A southern subterrane is composed of folded continental and shallow-marine lava, breccia, and andesite basalt tuff, basalt, rare andesite that yields K-Ar ages of 69 to $82 \mathrm{Ma}$, and local layers of sandstone, grit, and cherty siltstone containing wood and plant detritus. The southern subterrane is intruded by local gabbro and sheeted dikes.

\section{Subduction-Zone Units Linked to the Olyutorka Arc}

Tectonically linked to the Olyutorka arc was a subduction zone now preserved in the discontinuously exposed Vetlovskiy accretionary-wedge terrane (VT, figs. 1, 3, 7; Sokolov, 1992; Zinkevich and Tsukanov, 1992, 1993; Nokleberg and others, 1994a; Sokolov and Byalobzhesky, 1996). The Vetlovskiy terrane occurs in thin thrust sheets that are composed mainly of volcanic and sedimentary rocks, deep-water chert, mudstone, carbonate rocks, and midoceanic-ridge basalt (Vetlovskiy Complex; Fedorchuk and others, 1990; Tsukanov, 1991; Zinkevich and Tsukanov, 1992, 1993). The volcanic and sedimentary rocks range from Maastrichtian to lower Eocene.

\section{Origin of the Olyutorka Arc}

The Olyutorka arc is interpreted as having formed from subduction of part of the ancestral Pacific oceanic plate (Zonenshain and others, 1990; Sokolov, 1992; Zinkevich and Tsukanov, 1992, 1993; Nokleberg and others, 1994a; Sokolov and Byalobzhesky, 1996; Khudoley and Sokolov, 1998) and is partly preserved in the Vetlovskiy accretionary-wedge terrane (VT, figs. 1, 3, 7). This tectonic pairing is based on (1) occurrence of the Vetlovskiy terrane outboard of, and parallel to, the various island-arc terranes that constitute the arc (fig. 3); and (2) coeval, Late Cretaceous and early Tertiary deformation and accretion of units in the Vetlovskiy terrane. 
Subduction is generally interpreted as ending in the early Tertiary with accretion of the Olyutorka arc and associated subduction zone and subsequent outboard (oceanward) stepping of subduction to form the Kuril and Kamchatka igneous arcs (Zinkevich and Tsukanov, 1992, 1993; Nokleberg and others, 1994a; Sokolov and Byalobzhesky, 1996; Khudoley and Sokolov, 1998).

\section{Late Cretaceous and Early Tertiary Kluane and Coast Arcs in Southern Alaska and the Canadian Cordillera}

The Kluane arc is defined as an extensive suite of coeval Late Cretaceous and early Tertiary volcanic and plutonic rocks in southern and eastern Alaska. Remnants of the arc are preserved in the Kuskokwim Mountains sedimentary, volcanic, and plutonic belt (km, figs. 3, 4, 7), the Alaska RangeTalkeetna Mountains volcanic-plutonic belt (at, figs. 4, 7), and various coeval granitic plutons too small to show in figure 4 (Plafker and others, 1989a, b; Nokleberg and others, 1994a, b; Plafker and Berg, 1994; Monger and Nokleberg, 1996). Similarly, remnants of the Coast arc are preserved in the Coast-North Cascade plutonic belt (cn, figs. 4,7 ) and in the Kamloops magmatic belt (kl, fig. 4) in the Canadian Cordillera. These volcanic-plutonic belts form a major continentalmargin-arc sequence along the length of southern Alaska and the Canadian Cordillera, about 3,000 km. The various igneous-arc-related units of the Kluane and Coast arcs are grouped into a single arc on the basis of similar age, similar arc origin, geographic proximity, and simplicity. The Kluane and Coast arcs overlap the Wrangellia superterrane and adjacent, previously accreted inboard units, including the Yukon-Tanana, Stikinia, Cache Creek, and Quesnellia terranes (figs. 2, 4). The Kluane and Coast arcs are interpreted as having formed immediately after accretion of the Wrangellia superterrane in the Late Jurassic to mid-Cretaceous (Plafker and others, 1989a, b; Nokleberg and others, 1994a, b; Plafker and Berg, 1994; Monger and Nokleberg, 1996). Both the Kluane and Coast arcs are extensively disrupted by dextral-slip movement that occurred from the Late Cretaceous through the present on the Denali (DE), Tintina (TI), and companion faults (fig. 4).

\section{Rock Units of the Kluane Arc}

The Kuskokwim Mountains sedimentary, volcanic, and plutonic belt $(\mathrm{km}$, figs. $3,4,7)$ consists chiefly of volcanic and minor interlayered tuffaceous sedimentary rocks (Moll-Stalcup, 1990, 1994; Miller and Bundtzen, 1993; Moll-Stalcup and others, 1994). The belt also includes minor conglomerate to coarse-grained sandstone turbidite deposits deposited in deep-marine conditions, and lesser sandstone and conglomerate deposited in shallow-marine to nonmarine conditions along the flanks of the unit. The volcanic rocks consist chiefly of rhyolite and dacite domes, flows, and tuff and dacite, andesite, and basalt flows with isotopic ages of 58 to 77 $\mathrm{Ma}$. The unit also contains numerous related volcanoplutonic complexes, dikes, and plutons that exhibit a wide compositional range, including gabbro, quartz diorite, granodiorite, monzonite, and syenite. The Alaska Range-Talkeetna Mountains volcanic-plutonic belt (at, figs. 4,7 ) consists chiefly of large and small volcanic fields composed of calc-alkalic rhyolite, dacite, and andesite flows, pyroclastic rocks, and interlayered basalt and andesite flows (Plafker and others, 1989a, b; Moll-Stalcup, 1990, 1994; Moll-Stalcup and others, 1994). Isotopic ages range mainly from 50 to $75 \mathrm{Ma}$. The belt also contains numerous related diorite, quartz diorite, granodiorite, granite, and, locally, monzonite and syenite plutons.

\section{Rock Units of the Coast Arc}

The Coast-North Cascade plutonic belt (cn, figs. 4, 7) forms a major granitic plutonic belt that extends the length of the Canadian Cordillera into east-central Alaska. The belt consists chiefly of quartz diorite, granodiorite, and, locally, more mafic or felsic plutons (Gehrels and others, 1990; Rubin and others, 1991; Wheeler and McFeeley, 1991; van der Heyden, 1992; Woodsworth and others, 1992; Journeay and Friedman, 1993). Crystallization ages are generally younger toward the east. In the central and southern parts of the belt, age zonation permits division into three subbelts: (1) mid-Cretaceous and Late Cretaceous plutons (approx 96-70 Ma), (2) plutons that straddle the Cretaceous-Tertiary boundary (70-60 Ma), and (3) early Tertiary plutons (60-40 Ma). The early Late Cretaceous through early Tertiary intrusions were emplaced concurrently with structures formed sequentially during contraction and local(?) dextral transpression and transtension, accompanied by regional metamorphism (Rubin and others, 1991; Journeay and Friedman, 1993). The Kamloops magmatic belt (kl, fig. 4) consists chiefly of 46- to 55-Ma calc-alkalic to alkalic felsic, intermediate-composition, and mafic volcanic and sedimentary strata and comagmatic granodiorite, syenite, and quartz monzonite plutonic rocks (Ewing, 1980; Parrish and others, 1988; Symons and Wellings, 1989). The volcanic rocks may be surface equivalents of early Tertiary plutonic rocks in the eastern Coast belt (youngest part of Coast-North Cascade belt). In areas of the southern part of the Canadian Cordilleran and to the south, the belt is typically alkalic, and emplacement was concurrent with widespread basin-andrange-style extension.

\section{Subduction-Zone Units Linked to the Kluane and Coast Arcs}

Tectonically linked to the Kluane continental-margin arc were the younger parts of the Chugach terrane (Late Cretaceous accretionary-wedge Valdez Group) and the older part of the Prince William accretionary-wedge terrane (fig. 4). Both terranes occur in a similar tectonic position, as a series of narrow, discontinuous, long tectonic lenses situated outboard of the igneous-arc-related units of the Kluane arc (fig. 4). Tectonically linked to the Coast continentalmargin arc was the Pacific Rim accretionary-wedge and subduction-zone terrane that occurs outboard of the igneous-arc-related units of the Coast arc in the Canadian Cordillera (fig. 4). The Chugach and Pacific Rim terranes, 
described above in the subsection on the Gravina arc, were long-lived accretionary-wedge and subduction-zone complexes that formed from the Late Triassic through Late Cretaceous for the Chugach terrane (Nokleberg and others, 1994a; Plafker and Berg, 1994) and from the Late Jurassic though mid-Cretaceous for the Pacific Rim terrane (Nokleberg and others, 1994a; Monger and Nokleberg, 1996).

The Prince William accretionary-wedge terrane (PW, figs. 1, 2, 4, 7) consists chiefly of a complexly folded and faulted, thick assemblage of graywacke, argillite, minor conglomerate, pillow basalt, basaltic tuff, sills, dikes, and mafic and ultramafic rocks (Orca Group, Sitkalidak Formation, and Ghost Rocks Formation; Moore and others, 1983; Nelson and others, 1985; Dumoulin, 1988; Plafker and others, 1989a, b; Bol and others, 1992; Nelson, 1992; Bol, 1993). The terrane includes the Late Cretaceous and early Tertiary Ghost Rocks terrane of Jones and others (1987) and contains rare megafossils and microfossils of Paleocene and Eocene age. The terrane contains the Resurrection Peninsula ophiolite, which is interpreted as a remnant of the Kula-Farallon oceanic ridge that was subducted under the margin of southern Alaska (Lytwyn and others, 1997; Kusky and Young, in press).

\section{Origin of the Kluane and Coast Arcs}

The igneous-rock units that define the Kluane and Coast arcs are interpreted by most workers as various parts of a long continental-margin arc that was active during the Late Cretaceous and early Tertiary (Plafker and others, 1989a, b; Nokleberg and others, 1994a, b; Plafker and Berg, 1994; Monger and Nokleberg, 1996). The arcs are interpreted as having formed in response to subduction of part of the Kula oceanic plate. During subduction, substantial accumulations of igneous-arc-derived flysch (some from erosion of the Kluane arc) were deposited into a continental-margin trench bordering present-day southern Alaska. These deposits were underthrust along a major, north-dipping subduction zone (present-day coordinates) and underplated into a large accretionary-wedge complex of the Valdez Group of the southern Chugach terrane (Nokleberg and others, 1989; Plafker and others, 1989a, b; Plafker and Berg, 1994). Subduction is generally interpreted as ending in the early Eocene with accretion of the Kula oceanic plate and Kula Ridge and subsequent outboard (oceanward) stepping of subduction to form the modern-day Aleutian-Wrangell and Cascade arcs (Plafker and others, 1989a, b; Scholl and others, 1992, 1994; Plafker and Berg, 1994).

\section{Correlation, Linkage, and Alignment of Middle and Late Cenozoic Continental-Margin Arcs and Tectonically Paired Subduction Zones}

From about the early Eocene or Miocene through the present, three continental-margin arcs have been active around the Circum-North Pacific (figs. 3, 4): (1) the Northeast Asia arc, consisting of the East Japan volcanic-plutonic belt, the Central Kamchatka volcanic belt, the Central Kamchatka volcanic and sedimentary basin, the East Kamchatka volcanic belt, the Eastern Sakhalin sedimentary basin (too small to show in fig. 3), and the West Kamchatka sedimentary basin (also too small to show in fig. 3); (2) the Aleutian-Wrangell arc, consisting of the Aleutian volcanic belt (al, figs. 3, 4, 7) and the Wrangell volcanic field; and (3) the Cascade arc, consisting of the Cascade volcanic-plutonic belt.

\section{Northeast Asia Arc}

The Northeast Asia arc is a major continental-margin igneous arc that has been active since its inception in the early Eocene to Miocene. The arc is being preserved in the East Japan volcanic-plutonic belt (ej, fig. 3) and the Kamchatka arc, which consists of the Central Kamchatka volcanic belt $(\mathrm{kc})$, the Central Kamchatka volcanic and sedimentary basin (ck), the East Kamchatka volcanic belt (ek), the Eastern Sakhalin sedimentary basin (too small to show in fig. 3), and the West Kamchatka sedimentary basin (wk, fig. 7; Shahiro and others, 1987; Nokleberg and others, 1994a). This arc occurs along the entire length of northern Japan and the southern and central parts of the Russian Far East for about $2,500 \mathrm{~km}$. The Northeast Asia arc overlaps all previously accreted inboard terranes in the region (figs. 1, 3).

\section{Rock Units of the Northeast Asia Arc}

The East Japan volcanic-plutonic belt (ej, fig. 3) consists chiefly of Neogene to Holocene large andesite and rhyolite and smaller basalt volcanoes, dacite to andesite and lesser basalt lava, tuff, breccia, volcanic avalanche deposits and domes, and minor intermediate-composition plutons (Koji Wakita, in Nokleberg and others, 1994a). Major modern volcanoes occur at Oshima-oshima, E-san, Komagatake, Kariba, Raiden, Niseko, Toya, Usu, Yotei, Shikotsu, Tarumae, Tokachi, Daisetsu, Akan, Kutcharo, Masyu, and Shiretoko. The East Japan belt is coeval with the volcanic part of the Kuril arc to the northeast. The belt overlies many terranes of Hokkaido Island, including the Oshima (too small to show in figs. 1, 3, and 7), Sorachi-Yezo (SY), Kamuikotan (KK), Hidaka (HI), Tokoro (TO), and Nemuro (NE) terranes (figs. 1, 3, 7).

The Central Kamchatka volcanic belt (too small to show in fig. 3) consists chiefly of late Tertiary and Quaternary, thick, gently dipping andesite, dacite, and rhyolite strata, interlayered with sandstone, siltstone, and conglomerate, and widespread large ignimbrite fields (Erlikh, 1973; Popolitov and Volynets, 1981; Shapiro and others, 1987). Shallowmarine deposits are predominant in the lower part, and nonmarine deposits in the upper part. Formation of the belt culminated with eruptions of Pliocene to Quaternary plateau basalts that are associated with stratovolcanoes.

The Central Kamchatka volcanic and sedimentary basin (too small to show in fig. 3) consists chiefly of late Pliocene and Quaternary volcanic and sedimentary rocks, as much as $6 \mathrm{~km}$ thick; it ranges from 20 to $70 \mathrm{~km}$ in width and is 350 km long (Vlasov, 1964; Shapiro and others, 1987). The basin contains mainly shallow-marine sedimentary rocks and widespread tuff, basalt, and basaltic andesite. The basin overlies deformed Late Cretaceous to early Tertiary sedimentary rocks 
and is interpreted as a forearc unit for the Central Kamchatka volcanic belt.

The East Kamchatka volcanic belt (too small to show in fig. 3) consists chiefly of a major chain of modern volcanoes of Pliocene and younger age. The main rock types are basalt, andesite basalt, rare dacite, and tuff (Vlasov, 1964; Erlikh, 1973; Shapiro and others, 1987; Volynets and others, 1990). The belt is the northward continuation of the modern Kuril volcanic arc, which started to form during the Neogene.

The Eastern Sakhalin sedimentary basin (too small to show in fig. 3) consists chiefly of an Oligocene to Quaternary sedimentary basin, as much as 8,000 m thick (Baboshina and others, 1984, 1985; Kosygin, 1985). Seismic-reflection data suggest that late Miocene to Quaternary marine clastic and siliceous sedimentary rocks form most of basin.

The West Kamchatka sedimentary basin (too small to show in fig. 3) consists chiefly of thick, gently folded littoralmarine and nonmarine Cenozoic coal-bearing deposits, as much as $6 \mathrm{~km}$ thick (Vlasov, 1964, 1977). The basin contains major linear echelon folds that are diagonal to the general strike of basin. It is interpreted as an oblique-slip backarc basin for the Central Kamchatka volcanic belt to the east.

\section{Subduction-Zone Units Linked to the Northeast Asia Arc}

Tectonically linked to the Northeast Asia continentalmargin arc is the Kuril-Kamchatka accretionary-wedge and subduction-zone terrane (KUK), which occurs outboard of the arcs in northern Japan and the Russian Far East (figs. 1, 3, 7). The terrane is forming along the Kuril-Kamchatka megathrust (Nokleberg and others, 1994a) and consists chiefly of three major units (Lomtev and Patrikeev, 1965; Gnibidenko and others, 1980; Seliverstov and others, 1988). (1) A structurally lower unit is composed of bedded turbidites of Quaternary to Pliocene age and underlying oceanic crust. The turbidites generally range from about 100 to $500 \mathrm{~m}$ in thickness but are as much as 1,000 m thick near the junction of the KurilKamchatka and Aleutian Trenches. Seismic-reflection surveys indicate that the turbidites unconformably overlie oceanic crust. The turbidites are folded and deformed near the continental slope and can be traced below the accretionary-wedge unit at an angle of $5-15^{\circ}$. (2) A structurally emplaced upper unit consists of accretionary-wedge deposits that occur in a series of overthrusts which enclose fragments of the deformed bedded turbidites. Rocks dredged from the accretionary deposits consist of turbidites that contain Pliocene diatoms, Late Cretaceous oceanic chert that contains radiolarians, and basalt. (3) As determined from seismic-reflection surveys, an older, structurally higher part of the accretionary wedge consists of units bounded by numerous thrust faults. Rocks dredged from that part of the trench slope consist of turbidites that contain Miocene to Pliocene diatoms, as well as volcanic rocks that are metamorphosed to greenschist facies. Locally along the northwestern margin, this older part of the accretionary wedge lies in a depression as much as 20 $\mathrm{km}$ wide and consists of well-stratified turbidite deposits that range from 1.5 to $2.5 \mathrm{~km}$ in thickness. Transverse canyons along the trench are filled with Miocene to Quaternary turbidite deposits, as much as $3 \mathrm{~km}$ thick.

\section{Backarc Units Linked to the Northeast Asia Arc}

Also tectonically linked to the Northeast Asia continental-margin arc are the Sea of Japan (sj), the Sakhalin-Primorye (sp) volcanic belt, and the Kuril (kr) backarc units (figs. 3, 7). These three units consist of mainly alkalic or midoceanic-ridge-type basalt and related rocks, and all occur inboard (continentward) from the Northeast Asia arc (Uyeda, 1986; Tamaki, 1988; Tatsumi and others, 1989; Bogdanov and Til'man, 1992).

The Sea of Japan backarc unit (sj, figs. 3, 7) consists chiefly of volcanic rocks ranging in composition from midoceanic-ridge-type basalt to trachyrhyolite, as dredged from seamounts and ridges (Ingle and others, 1975; Bersenev and others, 1987). Tholeiitic basalt forms about 80 to 90 percent of the total dredged material; the rest is sparse clinopyroxene-olivine ferrobasalt. The basalt commonly contains lehrzolite xenoliths, has a predominant olivine-plagioclase mineral assemblage, and includes subordinate chromium clinopyroxene and chrome spinel. The age of the basalt is tentatively estimated at 0 to $15 \mathrm{Ma}$ from interpretation of the time of opening of the Sea of Japan, as determined by paleomagnetic data (table 3 ). The basalt is overlapped by a sedimentary cover, as much as $2 \mathrm{~km}$ thick.

The Sakhalin-Primorye volcanic belt (sp, fig. 7) consists chiefly of late Cenozoic basalt in relatively small eruptive fields that are closely associated with grabens and bounding faults (Semenov, 1982; Nakamura and others, 1990; Martynov and Okamura, 1993; Martynov, 1994). The basalt ranges in composition from quartz tholeiite to olivine nephelinite and includes basanite that locally contain xenoliths of spinel and garnet peridotite, pyroxenite, and harzburgite. Alkali basalt is predominant in the continental area of eastern China, whereas tholeiite, with an unusually low $\mathrm{K}_{2} \mathrm{O}$ content (less than 0.25 weight percent), occurs in the East Sikhote-Alin region adjacent to the rift basin of the Sea of Japan. On Sakhalin Island, the belt consists mainly of (1) Miocene subalkalic andesitebasalt, basalt, and rare rhyolite; (2) Late Miocene to early Pliocene trachybasalt, trachydiabase, and subvolcanic intrusions of monzonite, essexite, and other alkalic rocks; and (3) Pliocene olivine basalt and diabase, and rare andesite and dacite.

The Kuril backarc unit (kr, fig. 7; Gnibidenko and Svarichevsky, 1984; Sergeyev and Krasny, 1987; Maeda, 1990; Zonenshain and others, 1990) consists of (1) a central and northern part that is interpreted as Oligocene to Miocene oceanic crust, with an average seismic velocity of 6.7 to 7.0 $\mathrm{km} / \mathrm{s}$, a thickness of 12 to $13 \mathrm{~km}$, and a thin upper layer of sedimentary rocks, on the basis of inferred slow sedimentation rates (Zonenshain and others, 1990) and heat-flow values that are 2 to 2.5 times higher than in modern oceans; and (2) a southern part that is interpreted as a backarc unit which started to form at about $15 \mathrm{Ma}$. Local, partly buried volcanic cones are overlain by sedimentary rocks. Direct data on the composition and age of this backarc unit are absent. Dredging 
from the eastern part of the unit, on the west slope of the Kuril island arc, yields granitic rocks, which range in age from 94 to $219 \mathrm{Ma}$, and granitic clasts in conglomerate interlayered with Paleogene volcanic rocks.

\section{Origin of the Northeast Asia Arc}

The igneous-arc-related units that define the Northeast Asia arc are interpreted by most workers as various parts of a major active volcanic arc that occurs along the northeastern margin of Asia. The arc is interpreted as having formed in response to subduction of part of the Pacific oceanic plate and formation of the Kuril-Kamchatka accretionary-wedge and subduction-zone terrane (Parfenov and others, 1978; Parfenov, 1984; Parfenov and Natal'in, 1985; Zonenshain and others, 1990). Subduction is herein interpreted as commencing in about the Eocene after accretion of the Olyutorka arc and associated subduction zones to the Northeast Asia margin, and outward stepping of subduction. Also associated with the Northeast Asia arc are three major backarc units: the Sea of Japan backarc unit, the Sakhalin-Primorye volcanic belt, and the Kuril backarc unit, which are all inboard of the arc (fig. 3 ). The three backarc units are interpreted as the result of backarc rifting. The major rift basins that contain these units are interpreted as the loci of extension and thinning of previously accreted terranes, and as the loci of migration of the arc oceanward or away from the Northeast Asia continental margin (Uyeda, 1986).

\section{Aleutian-Wrangell Arc in Southern Alaska}

The Aleutian-Wrangell arc is a major intraoceanic (western part) and continental-margin (eastern part) igneous arc that started forming during the early Eocene to Miocene and is continuing to form through the present. The arc is being preserved in the Aleutian (al) volcanic belt and the Wrangell (wr) volcanic field (figs. 3, 4, 7; MollStalcup, 1990, 1994; Nokleberg and others, 1994a; Plafker and others, 1994; Vallier and others, 1994). This arc occurs along the entire south edge of the Bering Sea and southern Alaska for about 4,000 km. The Aleutian-Wrangell arc overlaps all previously accreted inboard terranes in the region (figs. 2, 4).

\section{Rock Units of the Aleutian-Wrangell Arc}

The Aleutian volcanic belt (al, figs. 3, 4, 7) comprises three parts (Harbert, 1987; Tsvetkov and others, 1990; MollStalcup, 1990, 1994; Bazhenov and others, 1992; Vallier and others, 1994). (1) The extreme western part of the arc in the Komandorsky Islands consists of Eocene and Miocene volcanic, tuffaceous, and sedimentary deposits, including basalt, andesite basalt, and andesite and interbedded tuff. The sedimentary rocks include sandstone, conglomerate, clay mudstone, and diatomite. This part of the arc is unconformably overlain by thin subalkalic basalt and alkalic basal middle Miocene tuff and tuffaceous siltstone, crossbedded sandstone and gritstone, and extensive interlayered Quaternary and Holocene glacial deposits. (2) The western part of the arc in the Aleutian Islands is subdivided into early (37-55 Ma), middle (5.3-37 Ma), and late series (5.3 Ma-Holocene; Scholl and others, 1992; Miller and Richter, 1994; Vallier and others, 1994). The early series forms the base of the arc and consists predominantly of flows and volcaniclastic rocks. Igneous composition ranges from basalt to rhyolite but is mainly calc-alkalic basalt and andesite. Local hypabyssal and plutonic rocks also occur. The middle series is predominantly volcanic flows, volcaniclastic rocks, conglomerate, and dolomite. Locally abundant sills, dikes, plugs, and large quartz diorite and granodiorite plutons also occur. The late series is predominantly sedimentary and volcanic strata, mainly in offshore basins and along the flanks of volcanoes. The early Tertiary part of arc, named the "Meshik arc" on the Alaska Peninsula, consists chiefly of andesite and dacite flows and volcaniclastic rocks. The younger, middle Tertiary through Holocene part of the arc consists of about 37 subaerial stratocones composed predominantly of calc-alkalic andesite to dacite flows, tuffs, and volcaniclastic rocks. (3) The eastern part of the arc on the Alaska Peninsula and in the Alaska Range overlaps the Peninsular sequence of the Wrangellia superterrane and consists of the 50- to 55-Ma Teklanika Formation, the 37to 45-Ma Mount Galena, Sheep Creek, and Post River volcanic complexes, and associated unnamed units that range in composition from basalt to rhyolite.

The Wrangell volcanic field (wr, figs. 4, 7) consists chiefly of andesite and lesser basaltic andesite shield volcanoes, satellitic cones, and andesite and lesser dacite flows, tuff, breccia, volcanic avalanche deposits, mudflows, and domes of 0 - to 20-Ma age (Miller and Richter, 1994). The volcanic field also includes lesser rhyolite and rhyodacite flows and domes, basalt and basaltic andesite cinder cones, and associated flows and dikes. Pyroclastic rocks are mainly lithic and crystal tuff, with lesser agglomerate and ash. Local associated shallow andesite plutons, dikes, dike swarms, and plugs also occur. The volcanic field overlies mainly the Wrangellia superterrane in south-central Alaska and locally is extensively interlayered with Quaternary and Holocene glacial deposits.

\section{Subduction-Zone Units Linked to the Aleutian- Wrangell Arc}

Tectonically linked to the Aleutian-Wrangell continentalmargin arc is the western (Attu Island) part of the Prince William accretionary-wedge terrane, which constitutes the younger part of the terrane (Nokleberg and others, 1994b); the Yakutat accretionary-wedge and subduction-zone terrane; and the modern-day subduction-zone complex that is forming inboard of the Aleutian megathrust (Plafker and others, 1994) (fig. 4).

The Attu Island part of the Prince William accretionary-wedge terrane (western part of PW, figs. 1, 2, 4, 7) consists predominantly of early Tertiary trench sedimentary rocks accreted to the hanging wall of the subduction zone (Cooper 
and others, 1987, 1992; Scholl and others, 1992; Plafker and others, 1994; Scholl and Hart, 1994). The terrane is exposed on the lower landward trench slope near the Attu and Kodiak Islands. The overall Prince William accretionary-wedge terrane is described in the above subsection on the Kluane arc.

The Yakutat accretionary-wedge terrane (YAK, figs. 2, 7) is a composite terrane that consists of the Mesozoic Yakutat Group in the eastern part and Eocene oceanic crust in the western part (Jones and others, 1981; Plafker and others, 1994). Both the eastern and western parts are overlain by younger Cenozoic sedimentary and volcanic rocks. The Yakutat Group is divided into (1) the melange facies, chiefly basalt, chert, argillite, tuff, and sandstone of Late Jurassic(?) and Early Cretaceous age, exotic blocks of Permian and Late Triassic carbonate rocks, and Middle and Late Jurassic tonalite; and (2) the flysch facies, chiefly Late Cretaceous volcanic sandstone, siltstone, and minor conglomerate, with structurally interleaved lenses of disrupted chert, argillite, and volcanic rocks. The Yakutat Group is metamorphosed from zeolite to lower greenschist facies and is intruded by Eocene granitic plutons. The Yakutat terrane is interpreted as a fragment of the Chugach terrane (Yakutat Group) and Eocene oceanic crust that, together with an overlying pre-Miocene sequence, was displaced at least $600 \mathrm{~km}$ northward along the Fairweather transform fault since the early Miocene. Isotopic studies by Heller and others (1992) suggest formation of the Cenozoic sedimentary rocks of the Yakutat terrane in a basin offshore of the U.S. Pacific Northwest and subsequent northward tectonic migration of about 600 km (Plafker and Berg, 1994).

\section{Origin of the Aleutian-Wrangell Arc}

The igneous-rock units that define the Aleutian-Wrangell arc are interpreted by most workers as various parts of an elongate continental-margin arc that has been active since its inception in the late Eocene (Plafker and others, 1989a, b; Scholl and others, 1992; Nokleberg and others, 1994a, b; Plafker and Berg, 1994; Plafker and others, 1994; Monger and Nokleberg, 1996). The arc is interpreted as having formed in response to successive, oblique subduction (combination of dextral slip and underthrusting) of three major units along the continentward-dipping Contact Fault (CO), the Aleutian megathrust (AL), and parallel intervening faults (fig. 4): (1) the younger, Paleocene and Eocene part of the Prince William accretionary-wedge terrane; (2) the Yakutat accretionarywedge terrane, with underthrust sedimentary rocks as young as Eocene; and (3) part of the Pacific oceanic plate (PAC, figs. $1,3,4)$. The Aleutian-Wrangell arc is not associated with any conspicuous backarc unit.

\section{Cascade Arc in the Southern Part of the Canadian Cordillera and the U.S. Pacific Northwest}

The Cascade arc is a major continental-margin igneous arc that continues to be active since its inception in the early Eocene. The arc is preserved in the Cascade volcanicplutonic belt (ca, figs. 4, 7; Wells and Heller, 1988; England and Wells, 1991; Goldfinger and others, 1996, 1997; Flueh and others, 1997). The Cascade arc overlaps all previously accreted inboard terranes in the region (figs. 2, 4).

The Cascade volcanic-plutonic belt (ca, figs. 4, 7) has both Canadian and U.S. parts (Vance and others, 1987; Wells, 1990; Walker and MacLeod, 1991; Smith, 1993). In the Canadian Cordillera, the belt consists of Pleistocene and Holocene basalt, andesite, and dacite eruptive centers and late Eocene(?), Oligocene, and Miocene plutons (Chilliwack and Mount Barr batholiths). The belt includes age-equivalent, possibly unrelated volcanic rocks (Masset Formation) on the Queen Charlotte Islands. In the U.S. Pacific Northwest, the belt consists of volcanic rocks of stratovolcanoes, mostly andesite but ranging in composition from basalt to rhyolite. The belt includes interbedded fluvial and lacustrine deposits and minor tonalite to granodiorite plutons. In Washington, parts of belt are included in the Ohanapecosh, Fifes Peak, and Northcraft Formations (Vance and others, 1987; Smith, 1993). The parts of the belt in Oregon are included in many formations and informal units, as listed by Walker and MacLeod (1991). The youngest active volcanoes in the belt are Mounts Jefferson, Hood, Adams, St. Helens, and Rainier.

\section{Subduction-Zone and Backarc Units Linked to the Cascade Arc}

Tectonically linked to the Cascade continental-margin arc are, from inboard to outboard, the Siletzia (SZ) subduction-zone terrane, the Olympic Core (OC) and Hoh (HO) accretionary-wedge terranes, and an unnamed, modern-day subduction complex forming along the Cascadia (CC) megathrust (figs. 2, 4, 7; Nokleberg and others, 1994a, 1997; Goldfinger and others, 1996, 1997; Flueh and others, 1997).

The Siletzia subduction-zone terrane (SZ, figs. 2, 4, 7) consists chiefly of basalt and greenstone of the early and middle Eocene Crescent and Metchosin Formations and the Siletz River Volcanics (Tabor and Cady, 1978; Muller, 1980; Wells and others, 1984; Clowes and others, 1987; Silberling and others, 1987; Babcock and others, 1992, 1993, 1994). The greenstone consists of metamorphosed tholeiitic pillow basalt, massive basalt, diabase, gabbro, tuff, and breccia. Intercalated with the greenstone are minor clastic rocks, ferruginous coccolithic limestone, and argillite. Total structural thickness of the terrane is more than $16 \mathrm{~km}$. On the Olympic Peninsula in Washington, the greenstone and basalt sequence appears to be stratigraphically underlain by continent-derived graywacke, argillite, and minor conglomerate (Tabor and Cady, 1978). Deep seismic-reflection studies on Vancouver Island, Canada, suggest that the Siletzia terrane was partly subducted beneath the Wrangellia superterrane (Clowes and others, 1987). The Siletzia terrane is stratigraphically overlain by middle and late Eocene turbiditic sedimentary rocks of the Northern Olympic forearc basin.

The Olympic Core accretionary-wedge terrane (OC, figs. $2,4,7$ ) consists chiefly of broken formation and melange composed of marine clastic rocks (Needles-Graywolf, Grand 
Valley, Western Olympic, and Lithic assemblages) that form the core of the Olympic Mountains, Washington (Tabor and Cady, 1978; Clowes and others, 1987; M.T. Brandon, written commun., 1993). The marine clastic rocks are poorly dated but probably are mostly late Eocene to Oligocene in age; however, some imbricated Miocene rocks also occur (M.T. Brandon, written commun., 1993). The terrane includes the western Olympic assemblage of Tabor and Cady (1978), part of which may correlate with part of the Yakutat terrane in southeastern Alaska (Heller and others, 1992). The Olympic Core terrane is interpreted as having been subducted under the Siletzia terrane along the Hurricane Ridge Fault. Deep seismic-reflection studies on Vancouver Island suggest that the Olympic Core terrane forms the lowest of several northeast-dipping thrust sheets that form the crust of Vancouver Island, above the presently subducting Juan de Fuca plate (Clowe and others, 1987).

The Hoh accretionary-wedge terrane (HO, figs. 2, 4, 7) consists chiefly of middle Miocene to late Oligocene melange and broken formation (Snavely and others, 1980; Clowes and others, 1987; Silberling and others, 1987). Onshore, the terrane consists of sandstone and siltstone in a sheared siltstone matrix on the western part of the Olympic Peninsula (Snavely and others, 1980). Deep seismic-reflection studies on Vancouver Island suggest that the Hoh terrane forms the lowest of the northeast-dipping thrust sheets which form the crust of Vancouver Island above the presently subducting Juan de Fuca plate (Clowes and others, 1987).

Also tectonically linked to the Cascade continental-margin arc is a major backarc-rift unit represented by the Columbia River Basalt Group (cr, figs. 4, 7). The group consists chiefly of thick flows of olivine tholeiite erupted as flood basalt, between middle and late Miocene (16.5 and $6 \mathrm{Ma}$ ), with minor interbeds of fluvial and lacustrine sedimentary rocks. The basalt in the group has an estimated volume of $210 \mathrm{~km}^{2}$ (Hooper, 1982; Bevier, 1988; Mathews, 1988; Hooper and Conrey, 1989; Wells and others, 1989; Wheeler and McFeely, 1991). The group is an extensive unit in central Washington and northern Oregon. In the southern part of the Canadian Cordillera, equivalent rocks of the group consist of the Chilcotin volcanic field of late Tertiary, mainly Oligocene(?), Miocene, and Pliocene age (2-16 Ma). The group consists mainly of subaerial, rarely subaqueous olivine basalt flows, intercalated pyroclastic rocks, and local gabbroic and basaltic intrusions. The group also locally contains younger volcanic centers of intermediate to felsic composition, such as the plume-related(?) Anaheim volcanic rocks and the riftrelated Ediza volcanic rocks (Wheeler and McFeely, 1991).

\section{Origin of the Cascade Arc}

The Cascade arc is a major continental-margin arc that has been active since the late Eocene (Wells and Heller, 1988; England and Wells, 1991; Goldfinger and others, 1996, 1997; Flueh and others, 1997). The arc is interpreted as having formed in response to successive, oblique subduction (combination of sinistral slip and underthrusting) of four major units along a series of continentward-dipping faults. From inboard to outboard, the four successively younger units that have been subducted and accreted during formation of the arc are (1) the middle Eocene Siletzia subduction-zone terrane, (2) the late Eocene to Oligocene Olympic Core accretionarywedge terrane, (3) the middle Miocene to late Oligocene Hoh accretionary-wedge terrane, and (4) the unnamed, modernday subduction complex forming above the Cascadia megathrust (CC). The Juan de Fuca oceanic plate is presently being subducted at the Cascadia megathrust (fig. 4). Also associated with the Cascade arc is the Columbia River Basalt Group, which is interpreted as having formed from backarc rifting during the middle and late Miocene. Associated with backarc rifting is extension and thinning of previously accreted terranes (Wells and Heller, 1988; England and Wells, 1991).

\section{Linkages Between Belts of Anatectically Related (Collisional) Igneous Rocks and Accretions of Terranes}

\section{Linkage of the Verkhoyansk Plutonic Belt with Accretion of the Kolyma-Omolon Superterrane to the North Asian Cratonal Margin}

\section{Characteristics of the Verkhoyansk Collisional Granite Belt}

The Verkhoyansk collisional granite belt, which occurs in the Russian Northeast, consists chiefly of two major belts: the Main collisional granite belt of Late Jurassic to early Neocomian age, and the Northern collisional granite belt of Neocomian age. The Main collisional granite belt (ma, fig. 3), which extends for about $1,000 \mathrm{~km}$ along the southwest border of the Kolyma-Omolon superterrane, stitches the superterrane to the North Asian cratonal margin (Verkhoyansk fold-andthrust belt; NSV, figs. 1, 3, 7). The Main belt consists of inclined sheetlike plutons, as much as $200 \mathrm{~km}$ long, that are generally conformable with major fold axes. Ar-Ar ages of granitic rocks range from 134 to $144 \mathrm{Ma}$ (Hackett and others, 1992; Layer and others, 1995; Fujita and others, 1997). Major rock types in the Main belt are a two-mica granite containing garnet, cordierite, and sillimanite, and a biotite and biotiteamphibole granite (Shkodzinsky and others, 1992; Trunilina and Orlov, 1997). A few initial ${ }^{87} \mathrm{Sr} /{ }^{86} \mathrm{Sr}$ ratios for granites in the Main belt are higher than 0.7060 (A.G. Bakha, written commun. to L.M. Parfenov, 1997). The regional metamorphism of the host Kula-Nera terrane, from lower greenschist to local epidote-amphibolite facies, is interpreted as having occurred during the collisional event.

The Northern collisional granite belt (no, fig. 3) extends for about $600 \mathrm{~km}$ along the northwestern margin of the KolymaOmolon superterrane. Ar-Ar ages of granitic rocks range from 120 to $127 \mathrm{Ma}$ (Layer and others, 1995; Fujita and others, 1997). The Northern belt consists of inclined sheetlike plutons, as much as $200 \mathrm{~km}$ long, that are generally conformable with major fold trends. Major rocks types are tonalite, granodiorite, and, less commonly, two-mica leucogranite (Shkodzinsky and others, 1992; Bakharev and others, 1988).

Within the Verkhoyansk fold-and-thrust belt (North Asian cratonal margin; NSV, figs. 1, 3, 7), discrete granite plutons 
of mid-Cretaceous age occur in the linear West Verkhoyansk granite belt (wvk, fig. 3), which extends for more than 1,000 $\mathrm{km}$ along a north-south strike (Parfenov and others, 1996). The plutons consist of granodiorite, granite, monzonite, and quartz monzonite with initial ${ }^{87} \mathrm{Sr} /{ }^{86} \mathrm{Sr}$ isotopic ratios of more than $0.707 .{ }^{39} \mathrm{Ar} /{ }^{40} \mathrm{Ar}$ isotopic ratios indicate ages of 95 to $108 \mathrm{Ma}$ (Fujita and others, 1997). Locally, these plutons are associated with epidote-amphibolite-facies regional metamorphism. Field relations suggest that regional metamorphism occurred immediately before granite intrusion. The age of metamorphism and granite intrusion is correlated with the intense deformation of the Verkhoyansk fold-and-thrust belt during the mid-Cretaceous to Late Cretaceous (Parfenov and others, 1996; Fujita and others, 1997), possibly in the same tectonic event that resulted in the formation of the OminecaSelwyn belt.

\section{Collisional Origin of the Verkhoyansk Granite Belt}

The Verkhoyansk collisional granite belt (consisting of Main and Northern parts) extends for 1,300 km along the southwestern and northwestern margins of the Kolyma-Omolon superterrane (fig. 3). The granite plutons in the belt intrude several major faults within the Verkhoyansk fold-andthrust belt (North Asian cratonal margin; NSV), the KulaNera terrane (KN), and the Uyandina-Yassachnaya volcanic arc (part of unit io, fig. 3) that formed on the margin of the Kolyma-Omolon superterrane (figs. 1, 3, 7; Parfenov and others, 1993a, b; Nokleberg and others, 1994a, b; Parfenov, 1995a, b). These relations indicate that the Verkhoyansk granite belt formed during and immediately after the collision of the Kolyma-Omolon superterrane to the east with the North Asian cratonal margin.

\section{Linkage of the Omineca-Selwyn Plutonic Belt to Mid-Cretaceous Accretion of Outboard Terranes Along the North American Continental Margin}

\section{Characteristics of the Omineca-Selwyn Plutonic Belt}

The Omineca-Selwyn plutonic belt (om, figs. 3, 4) occurs in the Canadian Cordillera, Alaska, and the northern part of the Russian Northeast for a strike length of about 4,000 km (Nokleberg and others, 1994a, 1997a-c). The belt includes the easternmost magmatic rocks in the Canadian Cordillera and the northernmost plutonic rocks in interior and northern Alaska and the northern part of the Russian Northeast. In the Canadian Cordillera, the belt consists chiefly of granodiorite, granite, quartz syenite, and minor syenite plutons of Early Cretaceous to mid-Cretaceous age (90-110 Ma) that form an extensive belt of discrete intrusions (Armstrong, 1988; Miller, 1989, 1994; Woodsworth and others, 1992). Many of the plutons exhibit S-type characteristics. The belt ranges in age from 90 to $110 \mathrm{Ma}$ and exhibits high initial ${ }^{87} \mathrm{Sr} /{ }^{86} \mathrm{Sr}$ ratios $(\geq 0.710)$ (Armstrong, 1988; Woodsworth and other, 1992). Extrusive equivalents, such as the South Fork volcanic rocks of the Yukon Territory and Canada, are rare.

In the Canadian Cordillera, various western Cordillera terranes (Slide Mountain [SM] and Quesnellia [QN], fig.2) were thrust over the distal Kootenay cratonal-margin terrane during the Early to Middle Jurassic (approx $185 \mathrm{Ma}$ ). The overthrusting was accompanied by high-grade metamorphism and complex deformation of the Kootenay terrane. From 185 $\mathrm{Ma}$, granitic rocks of the Omineca-Selwyn plutonic belt (om) show increasing evidence of crustal contamination. Precambrian zircons and higher initial ${ }^{87} \mathrm{Sr} /{ }^{86} \mathrm{Sr}$ ratios occur in the easternmost granites (Ghosh, 1995). During the mid-Cretaceous, the western terranes (Kootenay [KO], Quesnellia [QN], Slide Mountain [SM]) were overthrust eastward over the North American cratonal margin (NAM) and the North American Craton (NAC), with formation of the distinctive collisional granites of the Omineca-Selwyn plutonic belt (figs. 2, 4, 7). The position of this belt relative to west-dipping structures and isotopic geochemistry suggest that it formed by partial anatectic melting of structurally depressed continental crust. Alternatively, Armstrong (1988) interpreted these rocks as the rear part of a single Cordillera-wide mid-Cretaceous arc.

In interior and northern Alaska, the Omineca-Selwyn belt consists of large plutons of mid-Cretaceous granite and lesser syenite and granodiorite in an elongate trend that extends from east-central to west-central Alaska, the Seward Peninsula, and St. Lawrence Island. The belt includes the Ruby geanticline plutons of central Alaska (Miller, 1989, 1994; Foster and others, 1994; Patton and others, 1994) and the mid-Cretaceous and early Late Cretaceous granitic plutons of the Yukon-Tanana Upland (Pavlis and others, 1993; Foster and others, 1994). In interior Alaska, granitic plutons tend to be $\mathrm{K}$ rich, are locally ultrapotassic and $\mathrm{Na}$ depleted, are weakly to moderately peraluminous, are locally part of the ilmenite series, and exhibit S-type characteristics. These plutons are interpreted as the product of melting or contamination of continental crust. In the Chukotka terrane $(\mathrm{CH}$, figs. 1,7$)$ in the northern part of the Russian Northeast, the Omineca-Selwyn belt consists of a suite of Early Cretaceous granitic rocks that are overlain by volcanic rocks of Okhotsk-Chukotka volcanic-plutonic belt (oc, figs. 4, 7; Sosunov and others, 1982; Sosunov, 1985).

\section{Collisional Origin of the Omineca-Selwyn Belt}

The Omineca-Selwyn plutonic belt (om) occurs in a linear zone of intense mid-Cretaceous deformation that occurs along the inboard part of the North American orogen, about 200 to $300 \mathrm{~km}$ continentward from the accretionary margin of the North American continent. The plutonics rocks of the belt were intruded during the late stages of a period of intense contraction that was associated with orthogonal convergence between the Farallon oceanic plate and the North American Cordillera (Englebretson and others, 1985, 1992), and subsequent regional extension (Pavlis and others, 1993). In the Canadian Cordillera, the mid-Cretaceous plutons of the belt exhibit a strong crustal inheritance that may reflect Andean-style backarc thrusting and 
melting of the cratonal margin beneath the continental margin and accreted terranes during this episode of strong convergence (Monger and Nokleberg, 1996). The thrusting involved both cratonal-margin deposits and the overlying Jurassic and Cretaceous clastic deposits derived from the orogen. Similarly, in interior Alaska, in both the Ruby geanticline and the YukonTanana Upland, the plutonic belt intruded sedimentary and volcanic rocks of the two terranes during the waning stages of a complex period of compression and thrusting followed by regional extension (Pavlis and others, 1993; Nokleberg and others, 1995a, b). These geologic relations and the chemical and isotopic characteristics of the Omineca-Selwyn plutonic belt indicate genesis during anatexis associated with the late stages of, and immediately after, major terrane collision and orthogonal compression along the North America Cordillera in a narrow linear zone that extended from the southern part of the Canadian Cordillera, across interior Alaska, into the northern part of the Russian Northeast (figs. 3, 4).

\section{Paleomagnetic Constraints}

\section{Paleomagnetic Constraints for Plate Reconstructions of Northeast Asia and North America}

In the reconstructions of major tectonic plates presented in this study, principally the North American Craton and the North Asian Craton, we used a hierarchical, two-level approach. The first level was to reconstruct the relative positions of what became North America and North Asia for each time interval (stage). The second level was to position the relatively smaller terranes with respect to the major plates. The positions of terranes were determined primarily on the basis of stratigraphic and faunal data and, to a lesser degree, paleomagnetic data. In cases of data conflict, as discussed below for specific terranes on specific time-stage diagrams, terranes are positioned according to stratigraphic and faunal data rather than by paleomagnetic data.

From the Devonian to the present, the timespan that is modeled in this study, the relative motion between the North American and North Asian Cratons consisted of two phases. (1) Before the amalgamation of Pangea in the Permian, the Asian region consisted of several different plates. The North Asian Craton, one of the principal plates for this study, was sutured to Baltica (the Russian Platform) in the Late Carboniferous to Permian, during the final stage of the formation of Pangea. Baltica and the North American plate had already been sutured during the Silurian to Early Devonian Caledonian orogeny. (2) After the amalgamation of Pangea in the Permian, the second major phase of relative motion between the North American and North Asian Cratons was controlled by a protracted series of rifts that culminated in the Jurassic and later sea-floor spreading which formed the North Atlantic Ocean. These two phases of plate motion (suturing and subsequent rifting) control our methodology for defining plate positions in the tectonic model. After the Permian, the relative positions of North American and North Asian Cratons are constrained by plate reconstructions of the North Atlantic plate; for earlier times, paleomagnetic data are used as the principal constraint.

Reconstructions of the North Atlantic (North American relative to North Asian) region utilized in this study are from two principal sources. Reconstructions constrained by oceanicsea-floor-spreading data are based on the study by Srivastava and Tapscott (1986) that encompasses the Early Cretaceous to the present. From the Permian to the Late Jurassic, motion between the North American and North Asian Cratons was accommodated by rifting primarily in the present-day Rockall and North Sea areas around the British Isles. This rifting must have been accompanied by some horizontal motion between the plates, but published estimates of this motion indicate only a few tens of kilometers of motion (for example, Barton and Wood, 1984; Latin and White, 1990).

For pre-Permian reconstructions, before the North Asian region was amalgamated to Pangea, the relative positions of present-day North Asia and North America are based on paleomagnetic data, using the compilation by Van der Voo (1990) for North America and Baltica. For Siberia, we used the data of Khramov (1971, 1979, 1986a, b), Khramov and others (1985), and Didenko and Pechersky (1993). An additional constraint in the Paleozoic plate reconstructions is provided by geologic data. As is well known, paleomagnetic data alone cannot provide a unique plate reconstruction because of inherent longitudinal uncertainty.

\section{Paleomagnetic Constraints for Terranes and Overlap Assemblages}

For utilization of paleomagnetic data to construct the tectonic model, we compiled (table 3 ) and evaluated the documented paleomagnetic data available in the literature according to the selection criteria listed below. We evaluated and ranked each data set, accordingly assigning a grade between A (very good) and D (marginal). We rejected all other paleomagnetic data in the literature until such time as positive magnetic-stability tests of some type become available for them. The complete compilation of the paleomagnetic data is available from David B. Stone (or his Internet/World Wide Web site at URL http://www.gi.alaska.edu/TSRG/People/Stone/). Paleolatitudes mainly from data graded A, B, or C were utilized to constrain the latitudes of terranes for each time interval (stage) of the tectonic model. In some cases, the interpreted positions of specific terranes, according to stratigraphic and faunal data, conflict with the positions interpreted from paleomagnetic data. In such cases, we positioned the terranes primarily according to stratigraphic and faunal data and secondarily according to supporting paleomagnetic (paleolatitude) data. We discuss both supporting and conflicting paleomagnetic data for each time interval (stage) of the tectonic model. Discussions of apparent conflicts for terrane position according to stratigraphic and faunal data, on the one hand, versus paleomagnetic data, on the other hand, outline important new areas for future studies. Supporting paleomagnetic data are defined as those higher quality paleolatitude values, as ranked by criteria given below, that agree within about 5-8 of the positions determined by other geologic and faunal data; 
conflicting paleomagnetic data have paleolatitude values that differ by more than about $8-10^{\circ}$.

The criteria for ranking of paleomagnetic data are as follows.

Grade A.-Multiple demagnetization steps were applied to most or all of the samples, and statistically good fold or reversal tests were quoted, although in some cases we accepted other evidence of a positive stability test (for example, a conglomerate test or a baked-contact test).

Grade B.-Multiple demagnetization steps were applied to a significant number of the samples, and the author claims to have established positive stability for the magnetization.

Grade C.-Single-level, blanket demagnetization techniques were applied, and the author claims positive stability tests but has no supporting data, or else normal and reversely magnetized samples were combined (without any quantitative evidence that the magnetizations are antipodal). Grade $\mathrm{C}$ was also assigned to units where the ancient horizontal was poorly constrained, for example, in data from intrusive rocks.

Grade D. - The author claims to have data that represent the paleomagnetic field but gives no supporting evidence. Grade D is also used for units where the data seem accurate but where normal stability tests are impossible. All other data in the literature were rejected.

Paleolatitudes were calculated from the latitudinal displacements between the paleomagnetic poles for the sampled localities with respect to the North Asian Craton for the Russian Northeast or with respect to the North American Craton for Alaska and Canada. Many of the data for the Russian Northeast are derived from the compilations of $\operatorname{Khramov}(1971,1979$, 1986a, b), as reported in the global paleomagnetic data base of Lock and McElhinny (1991). The composite apparent-polarwander path (APWP) for the North Asian Craton for the preTriassic is from Khramov $(1971,1979,1986 a, b)$, who utilized data directly related to the craton. We used the APWP of Besse and Courtillot (1991) for the Triassic to the present stages of the tectonic model. This APWP is based on paleomagnetic pole-position data from many places rotated into the reference frame of the North Asian Craton by using paleogeographicreconstruction poles. We used the North American APWP of Van der Voo (1993) for the Paleozoic and older models, and that of Besse and Coutillot (1991) for the Triassic to the present models. Most displacements are southerly with respect to either the North Asian or North American Cratons; northerly displacements are listed as negative.

\section{Paleomagnetic-Variation Diagrams}

For this paleomagnetic analysis, we present five diagrams that illustrate paleomagnetic versus time values for terranes and overlap assemblages in the Circum-North Pacific (fig. 5). Paleolatitudes on these figures were calculated from paleomagnetic-inclination data from various combinations of terranes from the Russian Far East, Alaska, and the Canadian Cordillera. Two other paleomagnetic diagrams illustrate paleolatitude versus time values for the North Asian and North American Cratons (fig. 6). These paleomagnetic latitudes are interpreted as ancient geographic latitudes by using the common assumption that the time-averaged magnetic pole coincides with the geographic pole. The geologic age assigned to each of the paleomagnetic data points is based on information given by the cited authors, but when several points have the same nominal age, then we arbitrarily inserted separations of about 2 Ma to improve the clarity of the diagrams.

Two diagrams illustrate plots for the North Asian (Siberian) and North American Cratons, respectively, of paleolatitude versus time (fig. 6A). These values were calculated from the separation of the North Asian and North American sampling localities and from the paleomagnetic reference poles for the appropriate continental block. The two sets of reference poles were derived from the data of Besse and Courtillot (1991) for poles of Mesozoic age, and from the data of Van der Voo $(1981,1990,1993)$ and Didenko and Pechersky (1993), for poles of Paleozoic age for North America and North Asia, respectively. Quite large variations exist in the published APWP's for North Asia and, to a lesser extent, for North America, and so these reference latitudes should be used only as a guide.

The careful reader may note that the paleolatitudes for the continental blocks of the North Asian and North American Cratons (fig. 6) do not correspond exactly with the paleolatitudes shown in figures 7 through 20. The largest discrepancies occur for Siberia in the Late Triassic and Jurassic. The differences are due to the paleolatitudes shown in figures 7 through 20 being based on the paleomagnetic APWP's derived for each continental block (May and others, 1989), whereas the paleolatitudes shown in figure 6 are based on mean paleomagnetic poles from several continents after reconstructing the continental positions from around the Atlantic Ocean (Besse and Courtillot, 1991). These two approaches permit the reader to assess how tightly constrained the major tectonic framework is for any given time. A tectonically produced error in the North America paleomagnetic data may not be resolved (Butler and others, 1989).

\section{Kolyma-Omolon Superterrane}

The plot of paleomagnetic poles versus time for the Kolyma-Omolon superterrane (fig. 5A) includes values for the Omulevka terrane and smaller terranes that were accreted to the Kolyma-Omolon superterrane before collision with the North Asian Craton and adjacent passive continental margin (Verkhoyansk fold-and-thrust belt; NSV, figs. 1, 3, 7) at about the Middle to Late Jurassic. The paleolatitudes of the KolymaOmolon superterrane, from about the Middle Jurassic, closely match the latitudes expected for their present geographic positions. A strong indication exists that farther back in time, the terranes were displaced to the south by about $20^{\circ}$ of latitude. However, by the Devonian, two grade A data points indicate that the North Asian Craton and the Kolyma-Omolon superterrane were in close proximity. An exception is a single locality from the Rassokha terrane (RA) that yields a considerably lower paleolatitude (table 3 ), possibly representing a very rapid southerly excursion during the latest Devonian and 
Early Carboniferous, a problem with the interpretation of the geologic relations between these terranes, or an unresolved magnetic overprint.

\section{Outboard Terranes in the Russian Northeast}

The plot of paleomagnetic poles versus time for outboard terranes (fig. 5B) is for those terranes that are outboard of the Kolyma-Omolon superterrane toward the ancestral Pacific Ocean. These terranes formed in various tectonic settings and yield paleomagnetic data of varying quality. If the grade A data are given more weight than the other data sets, then a clear northward trend is evident for paleolatitude values that accelerates in the mid-Cretaceous and Late Cretaceous, such that these outboard terranes arrived at presentday latitudes by the Eocene. As defined above, grade A data pass more than one stability test. Together, all the data yield a very noisy picture, suggesting that some of the data sets, although they passed the selection criteria, may still contain a large component of remagnetization. Some of the grades $\mathrm{B}$ and $\mathrm{C}$ data were given relatively high grades on the basis of passing a fold test. The discrepancies seen may be due to postremagnetization folding, thereby giving a false impression of an original paleomagnetic record.

\section{Interior and Arctic Alaska}

The plot of paleomagnetic poles versus time for interior and Arctic Alaska (fig. 5C) is for all the terranes that occur north of the Denali Fault System. Only one data point exists north of the Brooks Range in the Arctic Alaska superterrane (AA). This data point is for a passive-continental-margin terrane that is interpreted as having formed originally adjacent to the North American Craton in the Canadian Arctic. The other data points are for terranes south of the Brooks range and from the Bering Sea region. For this region, the data hints at greater than $10^{\circ}$ of northward motion between the mid-Cretaceous and latest Cretaceous.

\section{South-Central Alaska}

The plot of paleomagnetic poles versus time for southcentral Alaska (fig. 5D) is for all terranes south of the Denali Fault System from the eastern Gulf of Alaska to the Bering Sea. Paleolatitudes clearly increase onward from the Late Carboniferous. This trend accelerates markedly during the mid-Cretaceous.

\section{Southeastern Alaska and the Canadian Cordillera}

The plot of paleomagnetic poles versus time for southeastern Alaska and the Canadian Cordillera (fig. 5E) shows data for all the terranes in this region. This plot shows a very marked northward increase in paleolatitude from the Late Carboniferous to the late Tertiary. Care should be taken when analyzing this plot, not only because of the wide range of present-day latitudes of the sampled sites but also because the overall motion of the North American Continent is nearly identical to that for these terranes. Relative to the North American Craton (fig. 6B), the motions are dominantly northward, but at a lower rate than the absolute paleolatitude motions shown in figure $5 E$.

\section{Paleomagnetic Dilemma: Loci of Accretion of the Wrangellia Superterrane}

A major paleomagnetic dilemma exists for the loci of accretion of superterranes to the North American cratonal margin during the mid-Cretaceous to early Tertiary. The dilemma consists of two conflicting hypotheses for the loci of accretion of the Wrangellia superterrane, which constitutes most of the Insular superterrane, and of the Intermontane superterrane, which consists of the Stikinia, Quesnellia, and Cache Creek terranes (Cowan, 1994; Cowan and others, 1997). One hypothesis, based on geologic evidence, including magmatic and stratigraphic ties, interprets the Wrangellia superterrane as accreting at a northerly paleolatitude, approximately at its present latitude. The other hypothesis, based on paleomagnetic data for both stratified and plutonic rocks, interprets the Wrangellia superterrane and the western part of the Intermontane terrane as accreting at a paleolatitude approximately 3,000 $\mathrm{km}$ farther south. This hypothesis is informally named the "Baja British Columbia controversy," in reference to accretion of the Wrangellia superterrane at the approximate latitude of Baja California (Umhoefer, 1987; Cowan and others, 1997; Dickinson and Butler, 1998). In our tectonic model, these two hypotheses are termed the "northern-accretion interpretation" and "southern-accretion interpretation."

Our tectonic analysis cannot currently discriminate between the two interpretations. Instead, the applicable parts of the tectonic model describe both the geologic and paleomagnetic data that support the northern-accretion interpretation, and the moderately abundant paleomagnetic data that support the southern-accretion interpretation. Accepting the northernaccretion interpretation requires radical reinterpretation of the paleomagnetic studies. Accepting the southern-accretion interpretation require (1) radical reinterpretation of the geologic data supporting the northern-accretion interpretation (Monger and others, 1996); (2) construction of a southerly route of tectonic migration starting in the Late Triassic, when the Wrangellia superterrane is interpreted to have formed at about $10^{\circ}$ paleolatitude (as discussed by Irving and others, 1996, and Cowan and others, 1997); (3) accretion of the Wrangellia (Insular) superterrane and, possibly, the western part of the Intermontane superterrane at the latitude of present-day Baja California at about 90 to 95 Ma (Irving and others, 1996; Cowan and others, 1997); and (4) a complex tectonic and rapid migration of the Wrangellia (Insular) superterrane and the western part of the Intermontane superterrane along the western part of the North American cratonal margin for a distance of about 3,000 km from about 83 to $34 \mathrm{Ma}$ (Cowan and others, 1997) along a series of faults (such as the Fraser 
Creek-Straight Creek and Ross Lake Fault Systems, fig. 20, and the Pasayten Fault in the southern part of the Canadian Cordillera) that do not display this amount of displacement (Monger and others, 1996). The various facets of this dilemma were discussed by Cowan (1994), Irving and others (1996), Monger and others (1996), Cowan and others (1997), Monger (1997), and Dickinson and Butler (1998); proposed tests of the two hypotheses were discussed by Cowan and others (1997).

\section{Phanerozoic Tectonic Model for the Circum-North Pacific}

\section{Introduction}

This model for the Phanerozoic tectonic evolution of the major geologic units of the Circum-North Pacific is based on the geologic and paleomagnetic constraints outlined above.

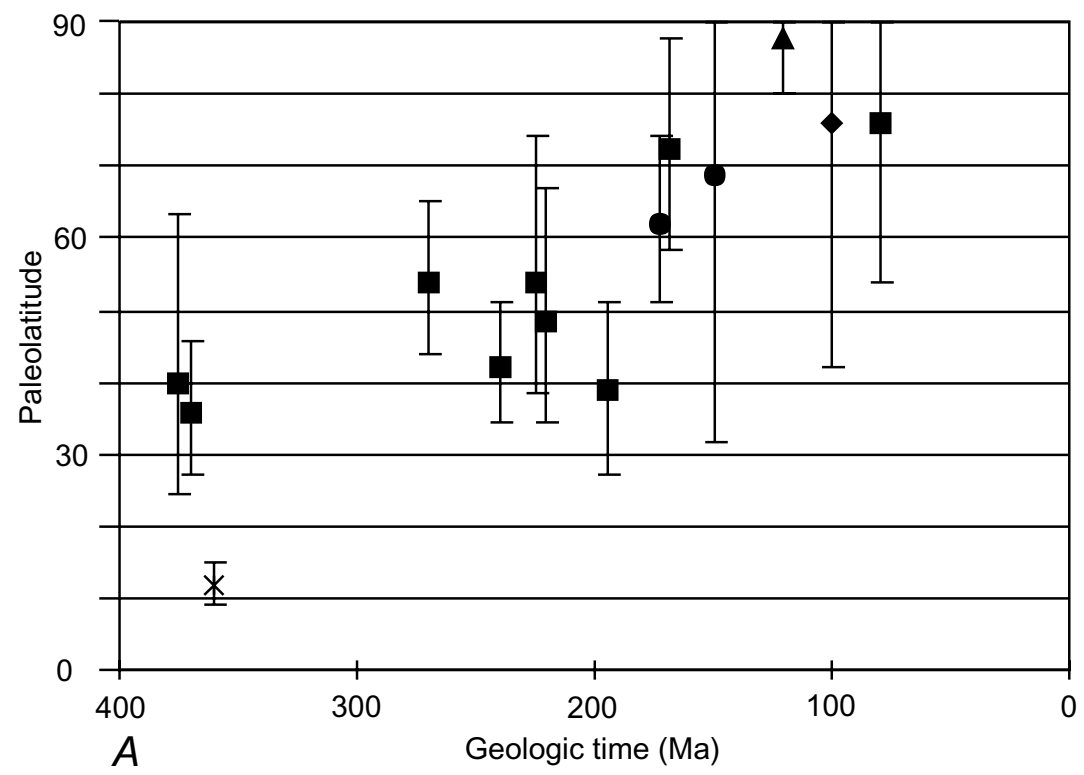

TERRANES
Khetachan
- Omulevka
- Oloy terrane, Eropol subterrane
- Oloy terrane, Siverskiy subterrane
* Rassokha

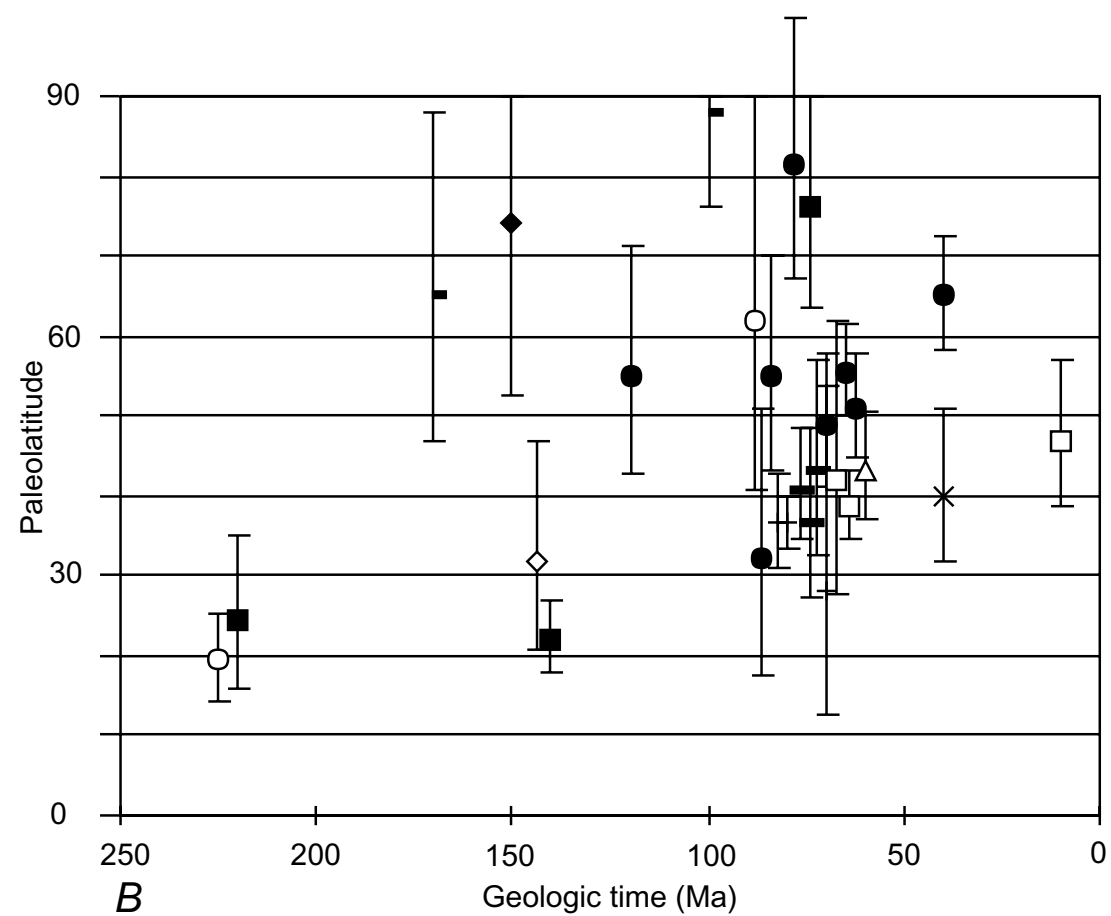

\begin{tabular}{|l|}
\hline TERRANES AND \\
OVERLAP ASSEMBLAGES \\
Alkatvaam terrane \\
$\Delta$ Ekonay terrane \\
$\triangle$ Aleutian volcanic belt \\
$\times$ Kronotskiy terrane \\
$\diamond$ Manitskiy terrane \\
+ Nemuro terrane \\
- Olyutorka-Kamchatka terrane \\
- West Sakhalin terrane \\
0 Talovskiy terrane \\
- Viliga terrane \\
$\square$ Vetlovskiy terrane
\end{tabular}

Figure 5.-Paleolatitude versus time for terranes and overlap assemblages in the Russian Far East, Alaska, and the Canadian Cordillera. $A$, Kolyma-Omolon superterrane. $B$, Outboard terranes in the Russian Northeast. $C$, Interior and Arctic Alaska. $D$, South-central Alaska. E, Southeastern Alaska and the Canadian Cordillera. Time scale from Palmer (1983). Plots are derived from table 3 and cited references; vertical bars represent range of paleolatitude in samples. See subsection of text entitled "Paleomagnetic-Variation Diagrams" for explanation. 

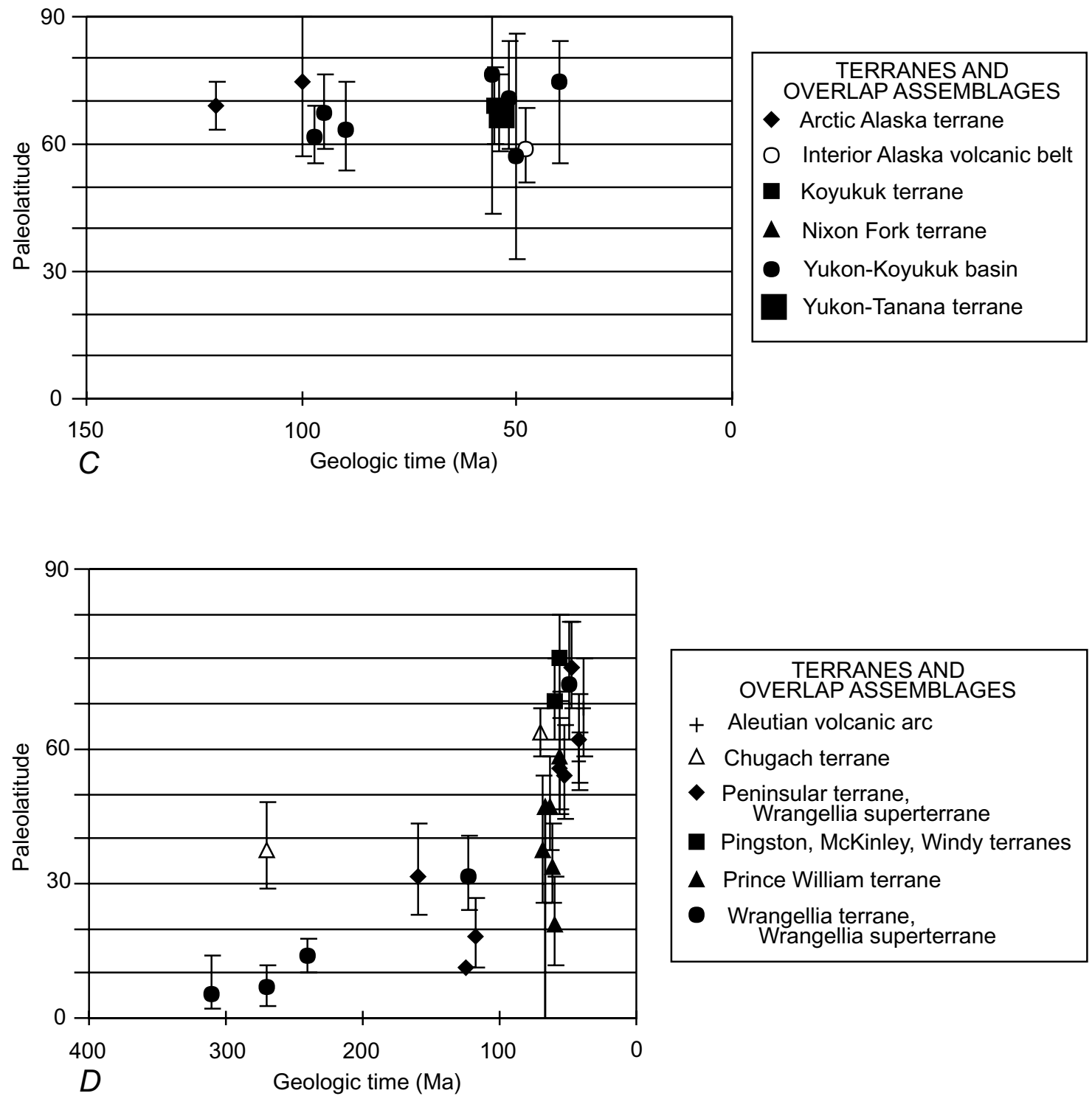

\section{TERRANES AND}

OVERLAP ASSEMBLAGES

+ Aleutian volcanic arc

$\triangle$ Chugach terrane

- Peninsular terrane, Wrangellia superterrane

- Pingston, McKinley, Windy terranes

$\Delta$ Prince William terrane

- Wrangellia terrane, Wrangellia superterrane

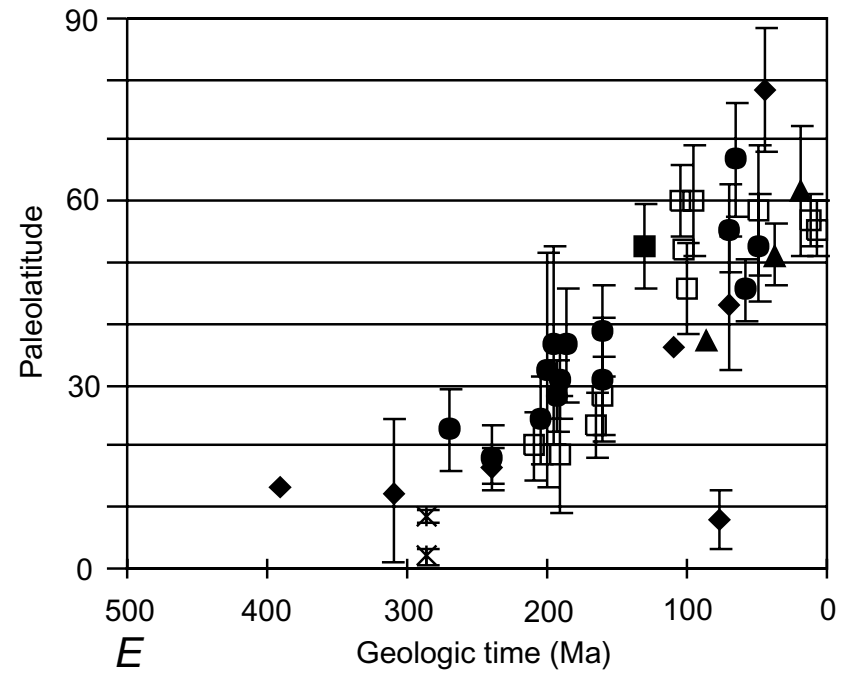

\section{TERRANES}

Alexander terrane, Wrangellia superterrane

- Cache Creek terrane

$\Delta$ Methow terrane

$\square$ Quesnellia terrane

* Slide Mountain terrane

- Stikinia terrane

Figure 5.-Continued. 
The model attempts to (1) integrate stratigraphic, age, structural, and paleomagnetic data and field relations for units of the Circum-North Pacific as summarized in tables 2 and 3, in above sections, and in supporting studies (Nokleberg and others, 1994a, 1997b); and (2) portray the regional tectonic interactions between the North Asian and North American Continents for the Devonian through the present (figs. 7-20). The tectonic model illustrates (1) proportionally sized units compared with those on the summary maps (figs. 1-4; Nokleberg and others, 1994a, 1997b, c; Monger and Nokleberg, 1996), and (2) known or interpreted displacements along major strike-slip and thrust faults. In most cases, however, the tectonic model does not incorporate internal deformation of terranes.
The tectonic model provides a guide for future research by (1) integrating geologic, paleontologic, isotopic, and paleomagnetic data from both the Russian Far East, Alaska, the Canadian Cordillera, the Pacific Ocean, and the Arctic Ocean; (2) proposing a new, unified interpretation that spans the area from the northeastern part of the North Asian Craton to the northwestern part of the North American Craton; and (3) identifying problems with data and interpretations. Because of a sparsity of Proterozoic and older rock units, exterior to the cratonal margins, the model starts with the Devonian (fig. 7). For various published tectonic reconstructions for the Proterozoic, which illustrate highly different global interpretations, we recommend the studies by Daziel (1991), Hoffman
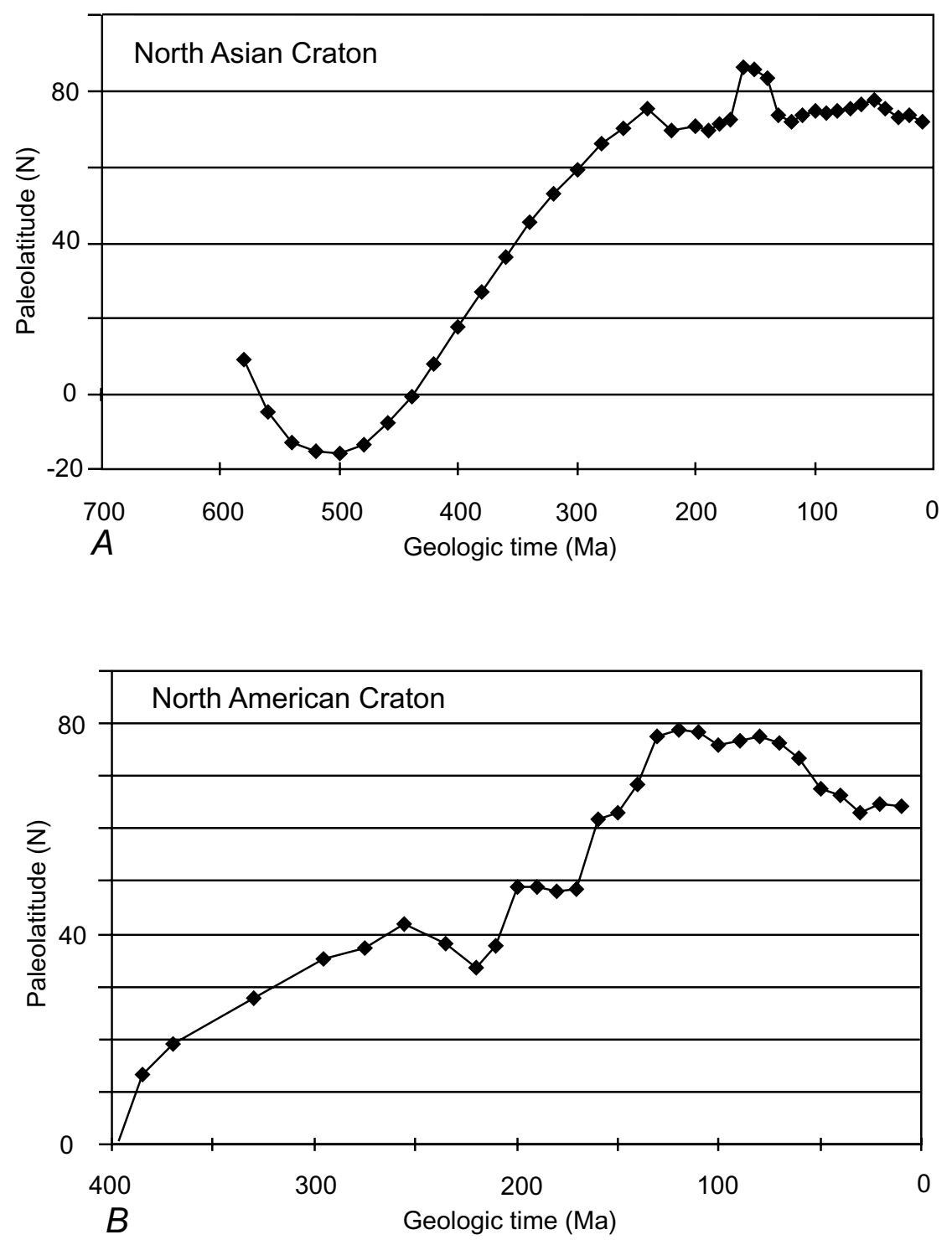

Figure 6.-Plots of paleolatitude versus time for the North Asian and North American Cratons. $A$, Paleolatitude versus time for a point (lat $66^{\circ} \mathrm{N}$., long $169^{\circ} \mathrm{E}$.) on the North Asian Craton. $B$, Paleolatitude versus time for a point (lat $62^{\circ} \mathrm{N}$., long $154^{\circ} \mathrm{W}$.) on the North American Craton. Time scale from Palmer (1983). Plots are derived from table 3 and cited references. See subsection of text entitled "Paleomagnetic-Variation Diagrams" for explanation. 
(1989, 1991), Moores (1991), Ross and others (1992), Scotese (1997), Unrug (1997), and Karlstrom and others (1999).

An important complexity of terrane recognition and analysis is that the margins of terranes have been tectonically removed, either by dislocation of terranes from distant locations or by tectonic erosion of the margins of terranes. In the case of dislocation, detailed analysis of each terrane with respect to inplace overlap assemblages, passive-continentalmargin assemblages, and cratonal assemblages should provide the original site of origin. In the case of tectonic erosion, as in the case of subduction-zone terranes, large parts of the original unit (such as an oceanic plate) may have been thrust to great depths and thereby may essentially have disappeared.

In some previous tectonic analyses, terranes have been portrayed as discrete fault-bounded entities. This type of portrayal, sometimes termed either "iceberg" or "motorboat tectonics," is partly the result of terranes being defined as fault-bounded units having distinctive stratigraphies. Our tectonic analysis, however, attempts to (1) recognize that each terrane was once part of a larger, more continuous stratigraphic succession of regional extent that was rarely bounded by faults originally; (2) correlate and group coeval terranes; and (3) group coeval igneous-arc terranes and tectonically linked subduction-zone terranes, where geologic data permit, into collinear, regional-extent arc/subduction-zone complexes. This type of tectonic synthesis might be termed "spaghetti tectonics."

An important interpretation in the tectonic model is that a succession of coeval single arcs and companion subduction zones formed on or near the margins of the North Asian and North American Continents, rather than migrating across ocean basins to accrete eventually to the margins of the continents. One consequence of this interpretation is that many of the complexities of the collage of accreted terranes in the region (figs. 1-4) are the results of oblique subduction and resulting strike-slip displacements within active continental margins. Substantiation of this interpretation will require (1) determination of the facing directions of the arcs with respect to cratons; (2) correlation of coeval arc and tectonically linked (companion) subduction zones to establish them as different parts of a former, single, curvilinear arc/subductionzone system; and (3) determination of the linkage of arcs to cratons. This interpretation is reasonably well established for most of the Mesozoic and Cenozoic, but less so for the Paleozoic.

For each time interval (stage) in the tectonic model, specific (numbered) tectonic events are described in clockwise order, starting with the area of the Russian Southeast and ending with the area of the southern part of the Canadian Cordillera. Following the descriptions of specific tectonic events are summaries of paleolatitude data that either support or conflict with the interpreted positions of terranes and overlap assemblages for each time interval. The face values of paleolatitudes from table 3 are employed; however, in some cases, the use of data with 95-percent-confidence limits implies a higher level of agreement than may be warranted. The time scale for the tectonic model is that of Palmer (1983).

\section{Mesozoic and Cenozoic Changes in Plate Motions}

Two major changes in Mesozoic and Cenozoic plate motions are interpreted for the Circum-North Pacific and were probably responsible for much of the tectonic evolution of the region (Plafker and others 1989b, 1994; Monger and Nokleberg, 1996). Each change was superposed on long-lived convergent plate margins. One major change in about the midCretaceous consisted of a reversal of relative offset between continental and oceanic plates. The other major change in the early Tertiary (fig. 17) resulted in overriding by the North American continental margin of the Kula-Farallon oceanic ridge and the Farallon oceanic plate, and accretion of part of the Kula oceanic plate.

Before about the mid-Cretaceous, the oceanic plates in the Circum-North Pacific were generally rotating clockwise with respect to the North Asian and North American Cratons, thereby producing a component of sinistral slip to major fault systems (Engebretson and others, 1985). From about the Late Cretaceous through the present, the Pacific plate has been rotating counterclockwise with respect to the North American plate, thereby producing a component of dextral slip to major fault systems (Engebretson and others, 1985). An intense period of orthogonal convergence between the ancestral Pacific Ocean plate and the North American Continent is interpreted for the mid-Cretaceous.

This change in absolute plate motions, which was superposed on a long-lived convergent plate margin, is probably responsible for the rise of the Canadian Cordillera (Monger and Nokleberg, 1996). In Alaska and the Canadian Cordillera, beginning with the Middle Jurassic and ending in the early Tertiary, most igneous-arc/subduction-zone complexes were accreted to the North American cratonal margin, and new continental-margin arcs were built on the mobile collage of accreted terranes. Subsequently, these arcs were fragmented by mainly dextral-slip faults and overprinted by still-younger arcs. This change probably resulted from long-continued northwestward, then westward, movement of the North American plate toward the subduction zone (Engebretson and others, 1985). The combination of strong plate coupling with oblique convergence created optimum conditions for orogen-parallel movements within the margin of the upper plate (Jarrard, 1986). Such movements probably occurred throughout much of the middle and late Mesozoic, but they are recorded in the substantial displacement along Late Cretaceous and early Tertiary dextral-slip faults in Alaska and the Canadian Cordillera.

The later change in absolute plate motion was subduction or overriding of the Kula-Farallon oceanic ridge and the Farallon oceanic plate along the margin of southern Alaska during the early Tertiary (Bradley and others, 1993) and accretion of a fragment of the Kula oceanic plate that underlies the modern Aleutian-Bowers sedimentary basin in the southern part of the Bering Sea (Scholl and others, 1992, 1994). The subduction of the oceanic ridge in the early Tertiary is interpreted as causing (1) a regional metamorphic welt and formation of anatectic granites (Plafker and others, 1989b, 1994), (2) rapid changes in components of strike-slip movement along subduc- 
tion zones bordering the early Tertiary margin of southern Alaska (Bradley and others, 1993), and (3) formation of two extensive belts of early Tertiary granitic rocks that formed in a near-trench environment (Bradley and others, 1993).

\section{Middle Through Late Devonian (387-360 Ma)}

During the Middle to Late Devonian (387-360 Ma), the major tectonic events were (1) formation of a discontinuous continental-margin arc (Kedon arc in the Russian Northeast) and associated subduction zone along the North Asian and North American cratonal margins; (2) during the Late Devonian, inception of rifting of the North Asian and North American Cratons and cratonal margins, resulting in the formation of new terranes and associated metallogenic belts (table 2); and (3) inception of the Sicker arc and associated subduction in what would eventually become the Wrangellia superterrane. Sedimentation continued along the North Asian and North American cratonal margins.

\section{Specific Tectonic Events for the Middle Through Late Devonian}

1. During the early Paleozoic, on the basis of paleomagnetic data, the North Asian Craton and cratonal margin (NSC, $\mathrm{NSV}, \mathrm{KN}$ ) migrated to a position adjacent to the North American Craton and cratonal margin (NAC, NAM) along a pre-Devonian sinistral-slip suture.

2. The Kedon continental-margin arc and associated subduction zone (KN) formed along the North Asian Craton and cratonal margin (NSC, NSV) and along the North American cratonal margin (NAM). In the North Asian cratonal margin and outboard terranes, the arc is preserved today in (1) sporadic occurrences of marine and continental volcanic and associated rocks and subduction-related granitic rocks in the southern part of the cratonal margin (NSV); (2) units that overlie parts of the Okhotsk (OK),Akekova (AK), and Omolon (OM) cratonal terranes; (3) the Oloy (OL) and Yarakvaam (YA) islandarc terranes; and (4) the Beryozovka turbidite-basin terrane (BE). Associated with this arc was the subduction of the older part of the Galam accretionary-wedge terrane (GL) along the North Asian Craton and cratonal margin (NSC, NSV), and subduction of the Angayucham and ancestral Pacific Oceans along the North American cratonal margin (NAM). In the North American cratonal margin (NAM) and outboard terranes, the arc is preserved today in sporadic occurrences of marine volcanic and associated rocks and shallow to deep-level subductionrelated granitic rocks in various parts of the Arctic Alaska (AA), Coldfoot (CO), Ruby (RB), Seward (SD), YukonTanana (YT), and Kootenay (KO) terranes. The Devonian arc is interpreted as extending discontinuously from present-day Arctic Alaska to northern California (Rubin and others, 1991; Smith and Gehrels, 1991; Mortensen, 1992; Nokleberg and others, 1994a; Plafker and Berg, 1994).
3. During the late Late Devonian, rifting of the North Asian and North American Cratons and cratonal margins occurred. Derived from the North Asian Craton (NSC) and cratonal margin (NSV) were the Kotelnyi (KT), Omulevka (OV), Prikolyma (PR), Nixon Fork-Dillinger-Mystic (NX, DL, MY), Viliga (VL), and Zolotogorskiy (ZL) passive-continental-margin terranes and the Avekova (AK), Kilbuck-Idono (KI), Okhotsk (OK), and Omolon (OM) cratonal terranes. Derived from the Devonian continentalmargin arc that formed along the North Asian cratonal margin were the Beryozovka (BE), Oloy (OL), and Yarakvaam (YA) terranes. The newly created terranes migrated into the Angayucham Ocean. Derived from the North American cratonal margin (NAM) were the Kootenay (KO) and Yukon-Tanana (YT) passive-continental-margin terranes.

4. The Sicker island arc was active along most of the length of the Wrangellia superterrane (WRA), which at this time was composed only of the Alexander terrane (AX). Associated with the Sicker arc was an unknown subduction zone (UNK). In the present-day southern part of the Canadian Cordillera, the Sicker arc is defined by the Sicker Group, which consists of Late Devonian arc-related volcanic and sedimentary strata with a U-Pb zircon age of $367 \mathrm{Ma}$, and coeval intrusions (Muller, 1980; Parish and McNicoll, 1992). Insufficient data exist to ascertain the relative positions of the Wrangellia superterrane and associated subduction zone. On the basis of paleomagnetic, geologic, geochronologic, and faunal data, the Wrangellia superterrane (Alexander terrane, AX) may have been derived from the Russian platform (Baltica) in the Barents Sea region (Bazard and others, 1993, 1994; Butler and others, 1997) or, possibly, from Australia (Gehrels and Saleeby, 1987; Butler and others, 1997).

\section{Summary of Paleolatitude Data for the Middle Through Late Devonian}

For the Russian Far East, supporting paleolatitude data (table 3 ) are $36^{\circ}$ (grade A) for the Omolon terrane. Conflicting paleolatitude data (table 3 ) include $12^{\circ}$ (grade B) for the Rassokha terrane.

For Alaska, supporting paleolatitude data (table 3) are (1) $14^{\circ}$ (grade B) for the Karheen Formation in the Alexander sequence of the Wrangellia superterrane, and (2) $37^{\circ}$ (grade A) for the Ordovician Novi Mountain Formation in the Nixon Fork terrane. Conflicting paleolatitude data include $23^{\circ}$ (grade A) for the Ordovician Telsitna Formation in the Nixon Fork terrane.

\section{Mississippian (360-320 Ma)}

During the Mississippian (360-320 Ma), the major tectonic events were (1) separation of the North Asian and North American Cratons and cratonal margins along a series of oblique-sinistral rifts, (2) ending of rifting of fragments from 
cratons and cratonal margins to form new terranes, and (3) continuation of the Sicker arc and associated subduction in what would eventually become the Wrangellia superterrane. Sedimentation continued along the North Asian and North American cratonal margins.

\section{Specific Tectonic Events for the Mississippian}

1. Starting in the late Devonian and ending in the Early Mississippian, rifting occurred along the eastern part of the North Asian cratonal margin (NSV, KN). This event formed the Kotelnyi (KT), Omulevka (OV), Prikolyma (PR), Nixon Fork-Dillinger-Mystic (NX, DL, MY), Viliga (VL), and Zolotogorskiy (ZL) passive-continental-margin terranes, the Avekova (AK), KilbuckIdono (KI), Okhotsk OK), and Omolon (OM) cratonal terranes, and the Beryozovka (BE), Oloy (OL), and Yarakvaam (YA) terranes. Before the rifting, these terranes were parts of either the North Asian Craton (NSC), the North Asian cratonal margin (NSV), or the Devonian continental-margin arc that formed along the North American and North Asian cratonal margins. The newly created terranes migrated into the Angayucham Ocean.

2. At the same time, rifting also occurred along the margin of the North American cratonal margin (NAM) to produce the Kootenay (KO) and Yukon-Tanana (YT) passivecontinental-margin terranes.

3. Movement along a series of oblique-sinistral rifts resulted in the separation of North Asian and North American Cratons and cratonal margins.

4. The Kedon continental-margin arc and associated subduction zone (KN) continued activity along the North Asian Craton and cratonal margin (NSC, NSV) until about the late Early Mississippian. Associated with the arc was subduction of the older part of the Galam (GL) accretionarywedge terrane. Remnants of the arc are preserved in (1) part of the North Asian Craton and cratonal margin; (2) units that overlie parts of the Okhotsk (OK), Akekova (AK), and Omolon (OM) cratonal terranes; (3) the Oloy (OL) and Yarakvaam (YA) island-arc terranes; and (4) the Beryozovka turbidite-basin terrane (BE).

5. The Sicker island arc, which formed in the Devonian along most of the length of the Wrangellia superterrane (WRA), ceased activity. Insufficient data exist to ascertain the relative positions of the Wrangellia superterrane.

\section{Pennsylvanian (320-286 Ma)}

During the Pennsylvanian (320-286 Ma), the major tectonic events were (1) inception of the older parts of StikiniaQuesnellia arc (Stikinia and Quesnellia terranes) (table 2) and associated subduction zone in the Yukon-Tanana (YT) and Kootenay (KO) terranes within an area offshore of the North American cratonal margin (NAM), and (2) formation of the Skolai island arc and associated subduction zone in the
Wrangellia superterrane. Sedimentation continued along the passive continental margins of North Asia and North America.

\section{Specific Tectonic Events for the Pennsylvanian}

1. Along the North Asian cratonal margin (NSC), dextral-slip occurred along the Mongol-Okhotsk suture (MO), resulting in displacement of its southern margin relative to the Mongol-Okhotsk Ocean.

2. Between the North Asian and North American Cratons, sporadic sea-floor spreading is interpreted as having enlarged the ancestral Pacific Ocean and formed the Oimyakon, Angayucham, and Goodnews Oceans. Fragments of the Oimyakon Ocean are preserved in the Debin and Garbyn'ya terranes (fig. 1). Fragments of the Angayucham and Goodnews Oceans are preserved in the Angayucham and Goodnews terranes, respectively (fig. 2). Within the Angayucham Ocean were the Kilbuck-Idono cratonal terrane (KI), derived from the North Asian Craton (NSC), and the combined Nixon Fork-Dillinger-Mystic passive-continental-margin terrane (NX, DL, MY), derived from the North Asian cratonal margin. During this timespan, before accretion to the present-day North American Continent, the combined Nixon Fork-Dillinger-Mystic terrane may have undergone several postrifting events that formed additional units, such as the siliciclastic rocks of the Sheep Creek Formation and the Mount Dall Conglomerate.

3. The intraoceanic Omulevka Ridge, which separated the Oimyakon and ancestral Pacific Oceans, consisted of the Omulevka (OV), Prikolyma (PR), and Omolon (OM) terranes. These terranes were previously rifted from North Asian Craton and cratonal margin during the Early Mississippian. The Paleozoic Yarakvaam (YA), Oloy (OL), and Alazeya (AL) island-arc terranes, together with the Beryozovka turbidite-basin terrane (BE), are interpreted as parts of an active island arc on an extension of the Omulevka Ridge.

4. Within the Angayucham Ocean, between the North Asian and North American Cratons and cratonal margins, was the Taimry Peninsula collage (TA) (Vernovskiy and others, 1998). This collage is interpreted as a series of Late Proterozoic ophiolite, island-arc, and passive-continental-margin terranes that were displaced along dextralslip faults along the North Asian cratonal margin (NSC, NSV, KN) (Zonenshain and others, 1990; Vernikovsky and others, 1998).

5. Fragments of the North American cratonal margin (NAM), (Anvil Ocean of Templeman-Kluit, 1979) between the Yukon-Tanana (YT) and Kootenay (KO) continentalmargin terranes and the North American cratonal margin.

6. At an unknown location, the Skolai island arc was active along the length of the Wrangellia superterrane (WRA). Associated with the arc was a presumed (unknown) subduction zone (UNK). The Skolai arc deposits consist mainly of Early to Middle Pennsylvanian plutons and Pennsylvanian and Permian marine volcanic and volcani- 


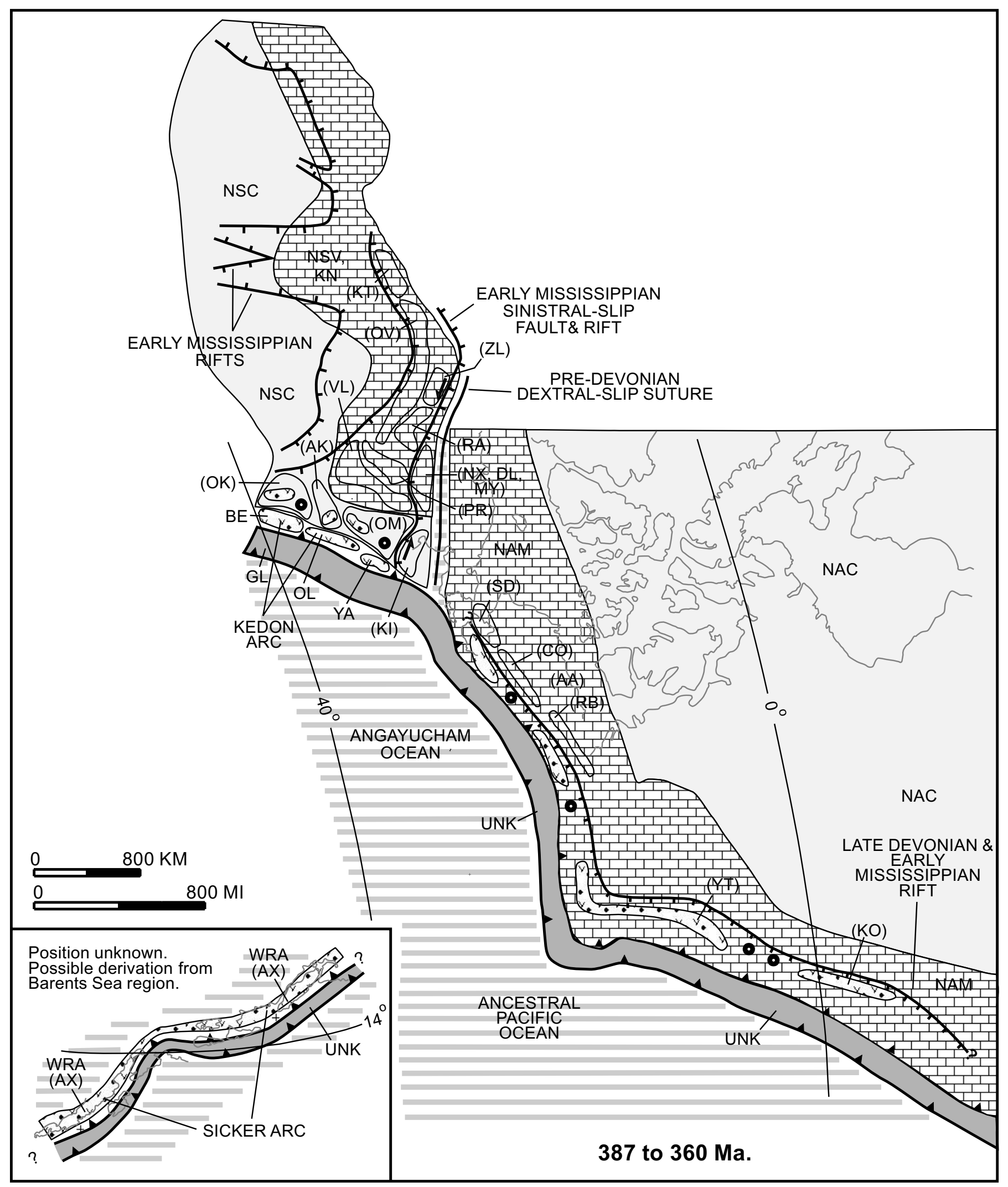

Figure 7.-Middle through Late Devonian (387-360 Ma) stage of tectonic model and explanation of tectonic model in figures 7 through 20 . See text for explanation of tectonic events. 
clastic rocks (Nokleberg and others, 1994b). The basement for the Skolai arc may in part be the Alexander sequence, which contains a fragment of an early and middle Paleozoic continental-margin arc (Nokleberg and others, 1994b). Insufficient data exist to ascertain the relative positions of the Wrangellia superterrane (and contained Skolai arc), and its associated subduction zone, with respect to the Stikinia and Quesnellia island-arc terranes and their associated subduction zones. Fauna in the Slana Spur and Eagle Creek (former Mankommen) Formations of the eastern Alaska Range indicate a high-latitude environment (Petocz, 1970).

\section{EXPLANATION}

\section{TECTONIC ENVIRONMENTS AND GEOLOGIC UNITS}

\section{CRATONAL}

Cratons (No patterns): NAC, North American; NSC, North Asian; NSS, Stanovoy block; Terranes: AK, Avekova; GN, Gonzha; KI, Kilbuck-Idono; OK, Okhotsk; OM, Omolon

\section{CRATON MARGIN}

Craton Margins: NAM, North American; NSV, North Asian (Verkhoyansk foldbelt; NSS, North Asian (Stanovoy block)

Passive continental-margin terranes (derived from craton margins): AA Arctic Alaska; AP, Artis Plateau; CA, Cassiar; CH, Chukotka; CK, Chukchi Cap; CO, Coldfoot; CS, Chukchi Spur; DL, Dillinger; KN, Kula-Nera; KO, Kootenay; KT, Kotel'nyi; LO, Lomonosov; MY, Mystic; NR, Northwind Ridge; NX, Nikon Fork; OL, Oldoi; OV Omulevka; PC, Porcupine; PR, Prikolyma; RA, Rassokha; RB, Ruby; SD, Seward; SR, Sredinny-Kamchataka; VL, Viliga; WS, Wickersham; YT, Yukon-Tanana; ZL,

CONTINENTAL-MARGIN ARC, ISLAND ARC, OR TURBIDITE BASIN

(Subduction-Related; Includes forearc \& backarc, and related turbidite basin deposits)

- Continental-margin arcs: al, Aleutian; at, Alaska Range-Talkeetna Mountains; bw, Bowers Ridge; ca, Cascade; ck, Central Kamchatka; cn, Coast-North Cascade; ej, East Japanl; ek, East Kamchatka; es, East Sikhote-Alin; gg, Gravina-Nutzotin-Gambier; io, Indigirka-Oloy; ka, Kamloops; kc, Central Kamchatka; kk, Kamchatka-Koryak; kh, Kahiltna; km, Kuskokwim Mountains; ko, Khingan-Okhotsk; ku, Kuril; mo, Monakin; no, North Okhotsk; oc, OkhotskChukotka; ol, Oloy; os, Oloy-Svyatov Nos; pn, Penzhina; ns Nelson; sb Spences Bridge; sh Shirshov Ridge; sv, Svyotoy-Nos; tt, Tahtsa-Twin Sisters- Francois Lake; ud, Uda; uo, Umlekan-Ogodzhin; wk, West Kamchatka; wr, Wrangell

Terranes: AL, Alazeya; AX, Alexander; BE, Beryozovka; BU, Bureya; CD, Cadwallader; CK, Chilliwack River; IR, Iruneisky; IZ, Izee; KE, Kema; KH, Khetachan; KLO, Kolyma-Omolon superterrane; KM, Kony-Murgal; KRO, Kronotskiy; KT, Kotel'nyi; KY, Koyukuk; LA, Lan; LD, Laoelin-Grodekorsk; MAI, Mainitskiy; MT, Methow; NE, Nemuro; NU, Nutesyn; NY, Nyac; PE, Peninsula; OF, Olds Ferry; OKA, Olyutorka-Kamchatka; OL, Oloy; QN, Quesnellia; SB, Stobolvskoy; SG, Sergeevka; SH, Shmidt; ST, Stikinia; SY, Sorachi-Yezo; TG, Togiak; TR, Terpeniya; UB, Uniya-Bom; WA, Wallowa; WP, West Pekul'ney; WR, Wrangellia; WRA, Wrangellia superterrane; WSA, West Sakhalin; YA, Yarakvaam

\section{SUBDUCTION-ZONE OR ACCRETIONARY-WEDGE COMPLEX, OR OPHIOLITE}

AG, Angayucham; AM, Amur River; AC, Aluchin; AGR, Argatas; ANV, Aniva; AV, Alkatvaam; BA, Baker; BD, Badzhal; BR, Bridge River; CC, Cache Creek; CG, Chugach; DB, Debin; EA, Easton; EK, Ekonay; GB, Garbyn'ya; GD, Goodnews; GL, Galam; GS, Grindstone; HI, Hidaka; HO, Hoh; KB, Khabarovsk; KK, Kamuikotan; KLM, Kiselevka-Manoma; KN, Kula Nera; KUK Kuril-Kamchatka; MU, Munilkan; NAB, Nabilsky; OC, Olympic Core; OS, Oshima; PA, PenzhinaAnadyr; PK, Pekul'ney; PR, Pacific Rim; PW, Prince William; SA, South Anyui; SM, Slide Mountain; SMA, Samarka; SV, Seventymile; SZ, Siletzia; TD, Turkuringra-Dzhagdi; TL, Talovskiy; TO, Tokoro; TR, Terpeniya; TU, Taukha; UL, Ulban; UNK, Unknown; VE, Velmay; VT, Vetlovskiy; WK, West Kamchatka; YAK, Yakutat; YN, Yanranay

\section{BACKARC SPREADING OR HOT-SPOT UNITS}

I I am, Alpha and Mendeleev Ridges; bs, Bering Sea; cr, Columbia River; kr, Kuril;

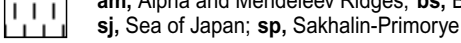

OCEANIC

Plates: FAR, Farallon; JF, Juan de Fuca; KULA, Kula; PAC, Pacific; EX, Explorer; Oceanic ridges: GK, Gakkel; JFR, Juan de Fuca; KOM, Komandorsky

POST-ACCRETION OVERLAP SEDIMENTARY AND VOLCANIC UNIT, SUBMARINE FAN, OR OCEAN BASIN DEPOSIT

- - ab, Amerasia Basin; ar, Anadyr; atb, Aleutian-Bowers; bo, Bowser; bu, Bureya; cb, Canada - Basin; cf, Cordilleran Foreland; co, Colville; eb, Eurasia Basin; kb, Kuibiveem; kn, Kandik River; kw, Kuskokwim

COLLAGE OF PREVIOUSLY ACCRETED TERRANES AND EXTINCT TERRANES, OVERLAP ASSEMBLAGES, AND BACKARC UNITS (names of units in parentheses)

COLL, Collages of various accreted terranes (some labeled); ASC, Academy of Sciences; IOC, Institute of Oceanology; KT, Kotel'nyi; TA, Taymyr Peninsula

\section{CONTACTS AND FAULTS}

(Dashed where concealed or approximately located; querried where unknown)

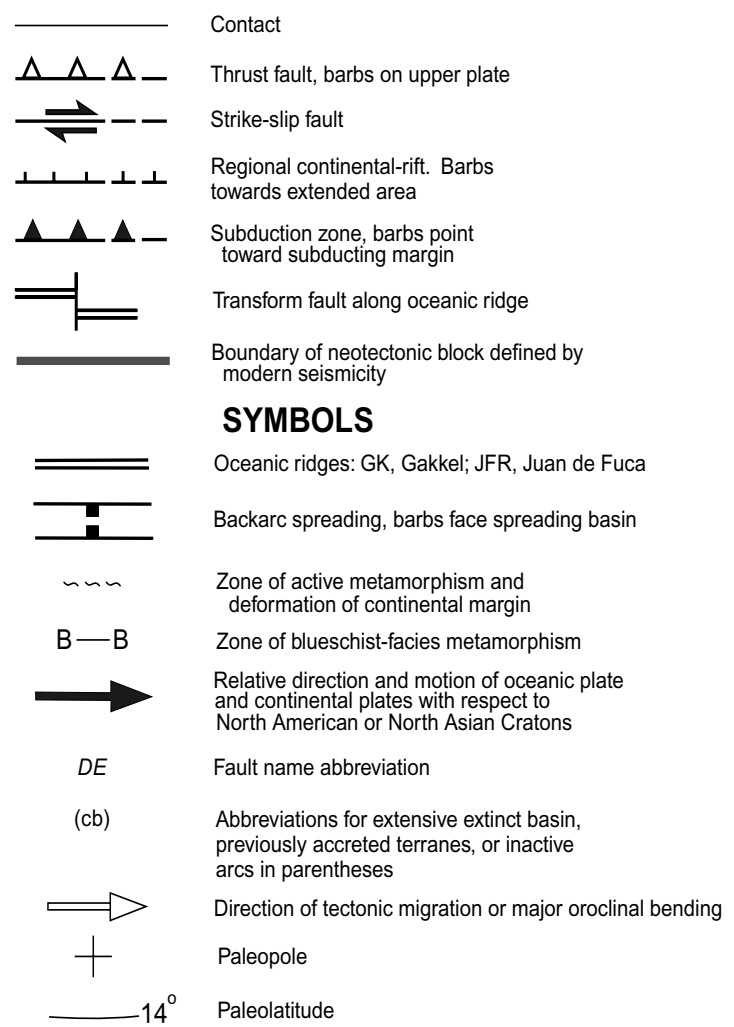

\section{PLUTONIC BELTS}

- Collisional granite belts: ma, Main; no, Northern; om, Omineca-Selwyn; tr, transverse; wvk, West Verkhoyansk

- Subduction-related continental-margin plutonic rocks

- Oceanic-ridge-related plutonic rocks: sab, Sanak-Baranof plutonic belt

\section{FAULT NAMES}

$A D$ Adycha-Taryn LE Lena

$A L$ Aleutian megathrust

LS Lyakhov-South Anyui

CA Central Sikhote-Alin

MO Mongol-Okhotsk

CC Cascadia megathrust

MY Myatisk

CO Contact

DE Denali

NF Nixon Fork

FS Frasier Creek-Straight Creek QC Queen Charlotte-Fairweather

HA Harrison SH Sakhalin-Hokkaido

$K A$ Kaltag

TE Teslin

TI Tintina

KK Kuril Kamchatka megathrust UL Ulban

KO Kobuk-South Fork UM Ulakhay

Figure 7.-Continued. 
7. Subsequently, during the Permian, most of the Stikinia-Quesnellia arc overlapped part of the Yukon-Tanana terrane after weak initiation of the arc in the Mississippian. This arc, defined by Permian granitic plutons in the Yukon-Tanana terrane and by the Stikine assemblage in the Stikinia terrane, may have been tectonically linked to subduction of part of the Seventymile Ocean. Evidence in the present-day Yukon Territory favors the Stikine part of the arc facing toward the North American cratonal margin (NAM) (Monger and Nokleberg, 1996). Along strike, the extension of the arc occurs in the Harper Ranch Group of the Quesnellia island-arc terrane (QN). Part of the arc was probably linked tectonically to subduction of part of the Cache Creek Ocean (Monger and Nokleberg, 1996).

8. Fauna of the Quesnellia and Stikinia terranes (QN, ST) are closest to those present-day Southwestern United States and northern Andean regions; the terranes probably formed along the continental margin at lower latitudes than their present positions. Quantitative estimates suggest that Stikinian fauna were situated anywhere from near

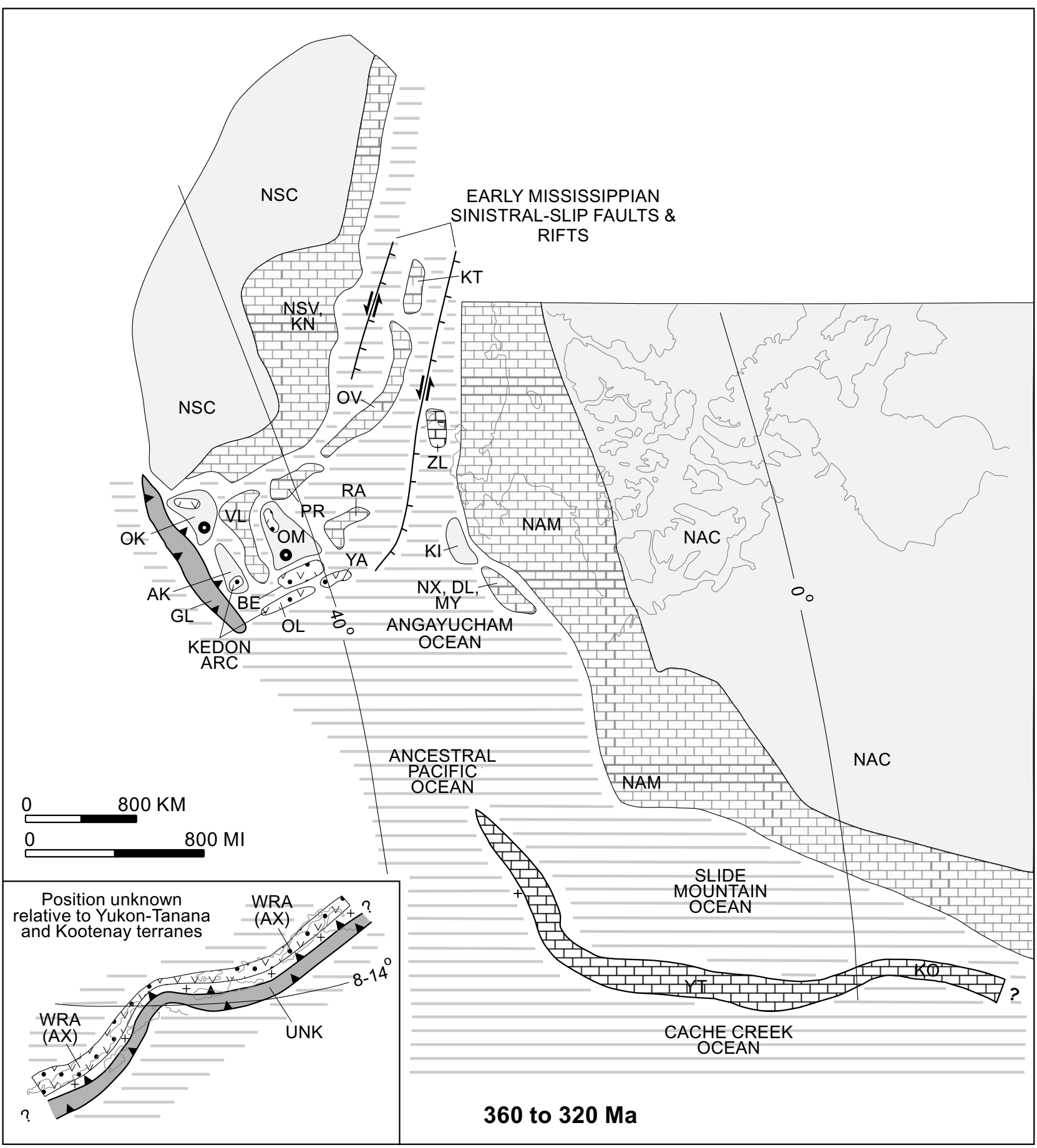

Figure 8.-Mississippian (360-320 Ma) stage of tectonic model and explanation of tectonic model. See text for explanation of tectonic events and figure 7 for explanation of abbreviations, symbols, and patterns. 


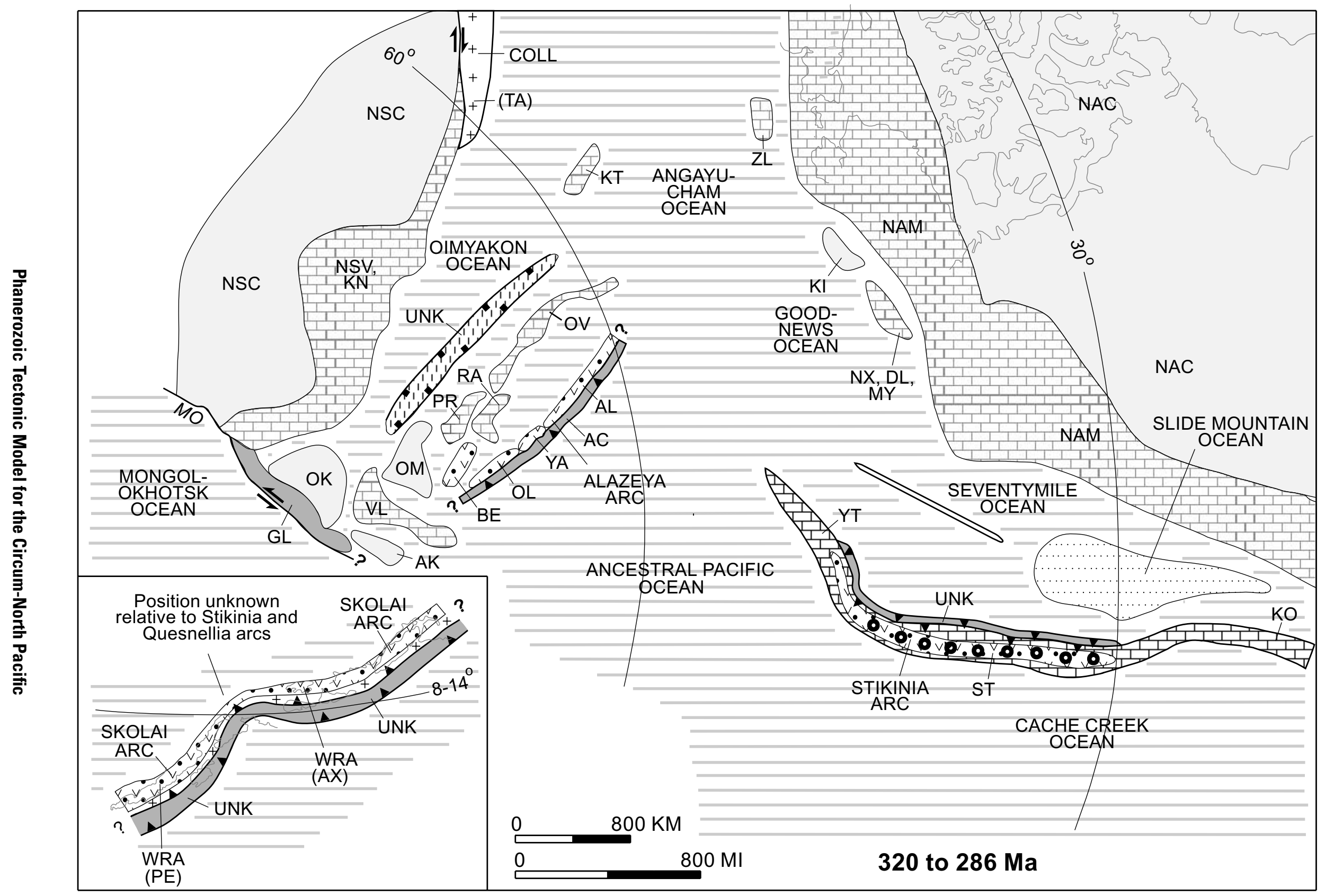

Figure 9.-Pennsylvanian (320-286 Ma) stage of tectonic model. See text for explanation of tectonic events and figure 7 for explanation of abbreviations, symbols, and patterns. 
0 to $8,000 \mathrm{~km}$ away from the craton (Belasky and Runnegar, 1994). The paleoposition of these Early Permian fauna is equivocal for that of the Wrangellia superterrane. Yole (1969) and Petocz (1970) suggested a high-latitude Uralian or Canadian Arctic affinity, whereas Belasky and Runnegar (1994) suggested low-latitude positions southeast of the present position of the Stikinia terrane. Paleomagnetic constraints on faunal locations are provided by Late Pennsylvanian-Permian data from the Slide Mountain terrane (SM), which suggest a post-Permian latitudinal shift of about $20^{\circ}$ northward with respect to the craton (table 3; Richards and others, 1993), whereas those from the Stikinia terrane exhibit little or no shift (table 3; Irving and Monger, 1987).

\section{Summary of Paleolatitude Data for the Mississippian, Pennsylvanian, and Permian}

In the Russian Far East, paleolatitude data (table 3) are $54^{\circ}$ (grade A) for unnamed sedimentary and volcanic rocks overlying the Omolon terrane.

For Alaska and the Canadian Cordillera, supporting paleomagnetic data (table 3 ) are (1) $8^{\circ}$ (grade A) for the Pennsylvanian Landrones and Klawak units in the Alexander sequence of the Wrangellia superterrane; (2) $14^{\circ}$ (grade A) for the Mississippian Peratrovich unit in the Alexander sequence of the Wrangellia superterrane; and (3) $6^{\circ}$ and $7^{\circ}$ (grades B, C) for two localities in the Pennsylvanian and Permian Station Creek and Hasen Creek Formations, respectively, in the Wrangellia sequence of the Wrangellia superterrane. Conflicting paleomagnetic data (table 3) are (1) $2^{\circ}$ and $9^{\circ}$ (grade A) for two localities (Sylvester allochthon and Sliding Mountain) in the Slide Mountain terrane, respectively; and (2) $23^{\circ}$ (grade A) for the Asitka Group in the Slide Mountain terrane in the central part of the Canadian Cordillera.

\section{Carnian Through Norian (230-208 Ma)}

During the Carnian to Norian (230-208 Ma), the major tectonic events were (1) inception of continental-margin arcs and associated subduction along the North Asian cratonal margin, (2) continued formation of the Stikinia island arc and inception of the Talkeetna and Bonanza island arcs and associated subduction zones offshore of the North American cratonal margin (table 2), and (3) beginning of sinistral-slip imbrication of the Stikinia-Quesnellia island arc and associated subduction zones. Sedimentation continued along the passive continental margins of North Asia and North America.

\section{Specific Tectonic Events for the Carnian Through Norian}

1. The continental-margin Uda arc, defined by the Uda volcanic-plutonic belt (ud) and associated units, commenced activity and was associated with subduction and sinistral transpression of the Mongol-Okhotsk oceanic plate to form the Turkuringra-Dzhagdi (TD) and Ulban (UL) terranes and the older part of the Galam (GL) terrane (table 2). Subduction and sinistral transpression occurred along the Mongol-Okhotsk suture (MO).

2. The extensive Kony-Murgal island arc (KM) commenced activity as an offshore extension of the Uda arc. Associated with this arc was subduction of part of the ancestral Pacific oceanic plate to form the Talovskiy (TL) and Penzhina-Anadyr (PA) terranes (table 2). Inboard of the Kony-Murgal arc, the Okhotsk (OK) cratonal terrane was accreted to the North Asian Craton (NSC) and cratonal margin (NSV), together with the Viliga (VL) passivecontinental-margin terrane and the Omolon (OM) and Avekova (AK) cratonal terranes. The Kony-Murgal terrane contains Triassic, Jurassic, and Neocomian Boreal fauna (Dagis and others, 1979; Dagis and Dagis, 1984; Zakharov and others, 1984); the Viliga terrane contains Carboniferous, Permian, Triassic, and Jurassic Boreal fauna.

3. The Alazeya arc, consisting of the Alazeya (AL) and Khetachan $(\mathrm{KH})$ island-arc terranes, continued activity and moved toward the Omulevka Ridge. Associated with the Alazeya arc was subduction of part of the ancestral Pacific Ocean to form the Aluchin (AC) and Argatas (ARG) accretionary-wedge terranes. These terranes can be traced by magnetic anomalies under extensive Cenozoic deposits of the present-day Russian Northeast (Parfenov, 1991). Behind the arc were fragments of previous Devonian to Pennsylvanian island arcs, including the Beryozovka turbidite-basin (BE) and the Oloy (OL) and Yarakvaam (YA) island-arc terranes.

4. The Kotel'nyi passive-continental-margin terrane (KT) was accreted and became part of the Taimyr Peninsular collage (TA). Within the Angayucham, Goodnews, and Seventymile Oceans were previously rifted terranes, including the Kilbuck-Idono cratonal terrane (KI) and the combined Nixon Fork-Dillinger-Mystic passive-continental-margin terrane (NX, DL, MY). During this timespan, before accretion to the North American Con-tinent, the combined Nixon Fork-Dillinger-Mystic terrane may have undergone several postrifting events that formed additional units, such as the Triassic basaltic rocks that occur in the present-day Tatina River area.

5. The complex Stikinia-Quesnellia island arc and associated subduction zones were active (table 2). The Stuhini Group is preserved in the Stikinia terrane (ST), whereas the Takla and Nicola Groups are preserved in the Quesnellia terrane (QN). The Stikinia-Quesnellia arc is interpreted as having formed stratigraphically on the Yukon-Tanana (YT) and Kootenay (KO) terranes, previously rifted fragments of the North American cratonal margin (NAM) (Mihalynuk and others, 1994). On the outboard side of the arcs was subduction of part of the Cache Creek oceanic plate to form the Cache Creek terrane (CC). The Cache Creek terrane and similar subduction-zone assemblages, which were tectonically linked to the Talkeetna and Bonanza arcs, along with the Chugach (CG), possibly Bridge River (BR), and Baker (BA) terranes, all contain exotic Permian 
Tethyan faunas in carbonate blocks in matrices of mainly early Mesozoic age. The Cache Creek terrane contains detritus probably derived from the Stikinia-Quesnellia arc (Monger and Nokleberg, 1996).

6. Parts of the Seventymile (SV) and Slide Mountain (SM) (Anvil Ocean of Templeman-Kluit, 1979) oceanic plates were obducted onto the Yukon-Tanana (YT) and Kootenay (KO) terranes and onto the North American cratonal margin (NAM). Part of the obduction occurred by the Late Triassic and (or) Early Jurassic, when granitic plutons of the Stikinia-Quesnellia arc intruded across an intervening fault.

7. The beginning of dextral-slip imbrication of the StikiniaQuesnellia arc occurred along the Tally Ho shear zone (inset, fig. 10A; Hansen, 1990; Hart, 1995). Alternatively, the present-day configuration of the Stikinia-Quesnellia island-arc and associated subduction zone terranes may have formed by oroclinal warping in response to a combination of oblique convergence and arc migration toward the companion subduction zone of the Cache Creek terrane (fig. 10B; Mihalynuk and others, 1994). Migration of the Stikinia-Quesnellia arc and associated terranes toward North America was accomplished by subduction and (or) obduction of the Seventymile oceanic plate along the continental margin.

8. The Talkeetna and Bonanza arcs formed along the length of the Wrangellia superterrane (WRA). The Talkeetna arc is preserved in the Talkeetna Formation and coeval granitic plutonic rocks of the Peninsular sequence (PE) of the Wrangellia superterrane, and the Bonanza arc is preserved in the Cadwallader island-arc terrane (CD). Associated with the island arcs was subduction of part the Cache Creek oceanic plate to form the Chugach (CG), possibly Bridge River (BR), and Baker (BA) terranes (table 2). These terranes locally contain early Mesozoic blueschist (Plafker and others, 1994).

9. During subduction of the Cache Creek oceanic plate to form the Talkeetna, Bonanza, and Stikinia-Quesnellia arcs, limestone blocks containing mainly Permian Tethyan faunas were accreted, locally in thick and extensive blocks in the subduction-zone complexes of the Chugach (CG) and Cache Creek (CC) terranes (Monger and Berg, 1987; Monger and Nokleberg, 1996). Tethyan faunas are generally interpreted as derived from the late Paleozoic and early Mesozoic Tethys Ocean of the present-day Mediterranean region, Middle East, Himalayas, Southeast Asia, eastern China, Russian Southeast, and Japan (Monger and Ross, 1971; Monger and others, 1972; Stevens and others, 1997).

10. In the Wrangellia superterrane (WRA), backarc rifting or hotspot activity formed the widespread basalt fields of the present-day Nikolai Greenstone and Karmutsen Formation (Barker and others, 1989; Richards and others, 1991; Lassiter and others, 1995). The mafic magmatism forming those rocks was first interpreted as having formed in a rift setting (Barker and others, 1989). Alternatively, the mafic magmatism may have formed in a short-lived mantleplume setting similar to that in Java (Richards and others, 1991; Lassiter and others, 1995).
Summary of Paleolatitude Data for the Carnian Through Norian

Supporting paleolatitude data for the Russian Far East (table 3 ) are $78^{\circ}$ (grade C) for the North Asian cratonal margin (Verkhoyansk fold-and-thrust belt; NSV, figs. 1, 3, 7). Conflicting paleolatitude data (table 3) are (1) $57^{\circ}$ (grade C) for the North Asian cratonal margin (Verkhoyansk fold-and-thrust belt), (2) $27^{\circ}$ for the Okhotsk terrane (grade B), (3) $42^{\circ}-54^{\circ}$ (grade C) for three localities in the Omolon terrane, and (4) $19^{\circ}$ (grade B) for a locality at Penzhino Gulf in the Talovskiy terrane.

For Alaska and the Canadian Cordillera, supporting paleolatitude data (table 3) are (1) $4^{\circ}-18^{\circ}$ (grades A, C) for seven localities - the McCarthy, Healy, Mount Hayes quadrangles, the Clearwater Mountains (two localities), the Amphitheater Mountains, Rainy Mountain, and the Slana River (two localities) - in the Nikolai Greenstone in the Wrangellia sequence of the Wrangellia superterrane in southern Alaska; (2) $18^{\circ}$ (grade A) for the Karmutsen Formation of the Wrangellia sequence in the Wrangellia superterrane in the southern part of the Canadian Cordillera; (3) $17^{\circ}$ (grade A) for the Hound Island unit in the Alexander terrane in southeastern Alaska; (4) $28^{\circ}$ (grade B) for the Nicola Volcanics in the Quesnellia terrane in the southern part of the Canadian Cordillera; and (5) $20^{\circ}$ (grade C) for the Guichon batholith in the Quesnellia terrane in the southern part of the Canadian Cordillera.

\section{Hettangian Through Pleinsbachian (208-193 Ma)}

During the Hettangian through Pleinsbachian (208-193 Ma), the major tectonic events were (1) continuation of continentalmargin arcs and associated subduction near the North Asian Craton in the Russian Far East; (2) beginning of assembly of previously rifted cratonal, passive-continental-margin, and islandarc terranes between that craton and the ancestral Pacific Ocean to form the Kolyma-Omolon superterrane; (3) continuation of the Talkeetna, Bonanza, and Stikinia-Quesnellia arcs and formation of companion subduction zones (table 2); (4) continued sinistral-slip imbrication of the Stikinia-Quesnellia island arc and associated subduction zones during oblique-sinistral convergence between the ancestral Pacific oceanic plate and the North American cratonal margin; and (5) with the beginning of accretion of the Stikinia-Quesnellia arc at about $185 \mathrm{Ma}$, the start of mountain building in the North American Cordillera. Sedimentation continued along the passive continental margins of the North Asian and North American Cratons.

\section{Specific Tectonic Events for the Hettangian Through Pleinsbachian}

1. The Monakin continental-margin arc, consisting of the Monakin volcanic-plutonic belt (mo) and the Umlekan 
continental-margin arc, consisting of the Umlekan-Ogodzhin volcanic-plutonic belt (uo) and associated units, commenced activity. Associated with this arc was oblique (sinistral) subduction of part of the ancestral Pacific oceanic plate to form the Samarka (SMA), Khabarovsk (KB), and Badzhal (BD) terranes (table 2).

2. The Uda continental-margin arc, consisting of the Uda volcanic-plutonic belt (ud) and the Uda-Zeya sedimentary basin (uz), continued to form. Associated with this arc was subduction and sinistral transpression of part of the
Mongol-Okhotsk oceanic plate to form the TurkuringraDzhagdinski (TD), Ulban (UL), and Galam (GL) terranes (table 2). Subduction and sinistral transpression occurred along the Mongol-Okhotsk suture (MO).

3. The extensive Kony-Murgal island arc (Kony-Murgal terrane, $\mathrm{KM}$ ) continued to form as an offshore extension of the Uda arc. Associated with the arc was subduction of part of the ancestral Pacific oceanic plate to form the Talovskiy (TL) and Penzhina-Anadyr (PA) terranes (table 2). Inboard of the Kony-Murgal island arc (KM) were

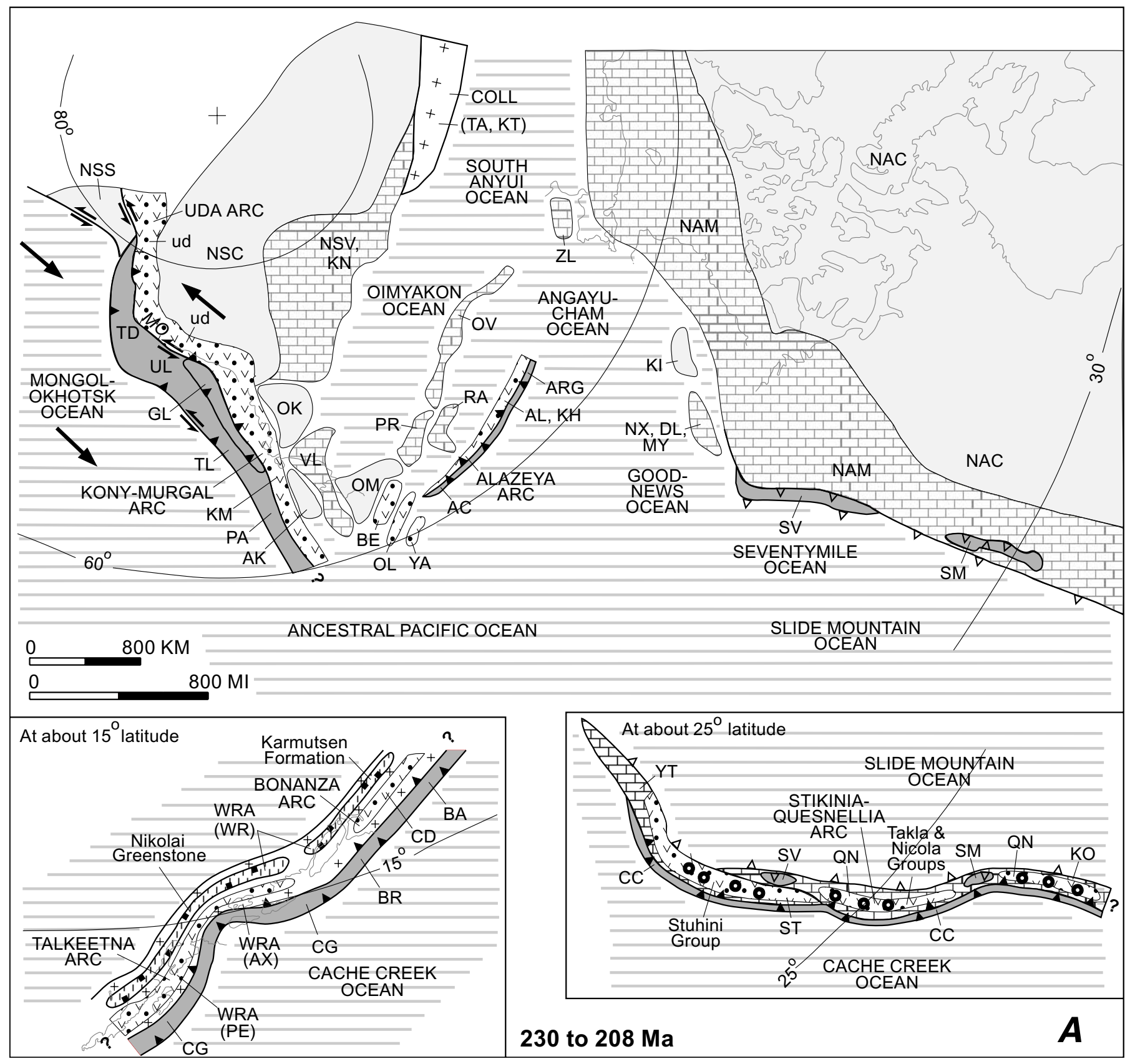

Figure 10.-Carnian through Norian (230-208 Ma) stage of tectonic model. $A$, Tectonic model for the Circum-North Pacific. Insets show models for the Wrangellia superterrane and beginning of strike-slip imbrication of Stikinia-Quesnellia island-arc and related terranes. $B$, Alternative interpretation for tectonic evolution of Stikinia-Quesnellia island-arc and related terranes, showing beginning of oroclinal warping. See text for explanation of tectonic events and figure 7 for explanation of abbreviations, symbols, and patterns. 
the Okhotsk (OK), Avekova (AK), and Omolon (OM) cratonal terranes, which were previously rifted from the North Asian Craton (NSC), and the Viliga (VL) passivecontinental-margin terranes, which was previously rifted from the North Asian cratonal margin (NSV). Behind the arc were fragments of previous Devonian to Pennsylvanian island-arc terranes, including the Beryozovka turbidite-basin (BE) and the Oloy (OL) and Yarakvaam (YA) island-arc terranes.

4. The Angayucham Ocean (Kobuck Sea of Plafker and Berg, 1994), along with the South Anyui Ocean, continued to receive sparse continent-derived detritus. Previously rifted terranes, including the Kilbuck-Idono cratonal terrane (KI) and the combined Nixon ForkDillinger-Mystic passive-continental-margin terrane (NX, DL, MY), continued to migrate toward the North American cratonal margin.

5. Dextral-slip imbrication of the Stikinia-Quesnellia arc and associated subduction-zone terranes continued along the Tally Ho shear zone (inset, fig. 11A; Hansen, 1990; Hart, 1995). Part of this shear zone may be defined by a string of fault-bounded(?) ultramafic rocks that occur within the Yukon-Tanana terrane in the northern part of southeastern Alaska (Himmelberg and others, 1985). Alternatively, the present-day configuration of the Stikinia-Quesnellia island-arc and associated subduction-zone terranes may have formed by oroclinal warping in response to a combination of oblique convergence and arc migration toward the companion subduction zone of the Cache Creek terrane (fig. 11B; Mihalynuk and others, 1994). Oroclinal warping is interpreted as having formed in response to (1) oblique-sinistral convergence between the ancestral Pacific oceanic plate and the Stikinia-Quesnellia arc; and (2) arc migration toward the companion subduction zone (trench rollback), similar to the tectonics of the presentday Banda arc in Southeast Asia (McCaffrey and Abers, 1991; Mihalynuk and others, 1994). Migration of the

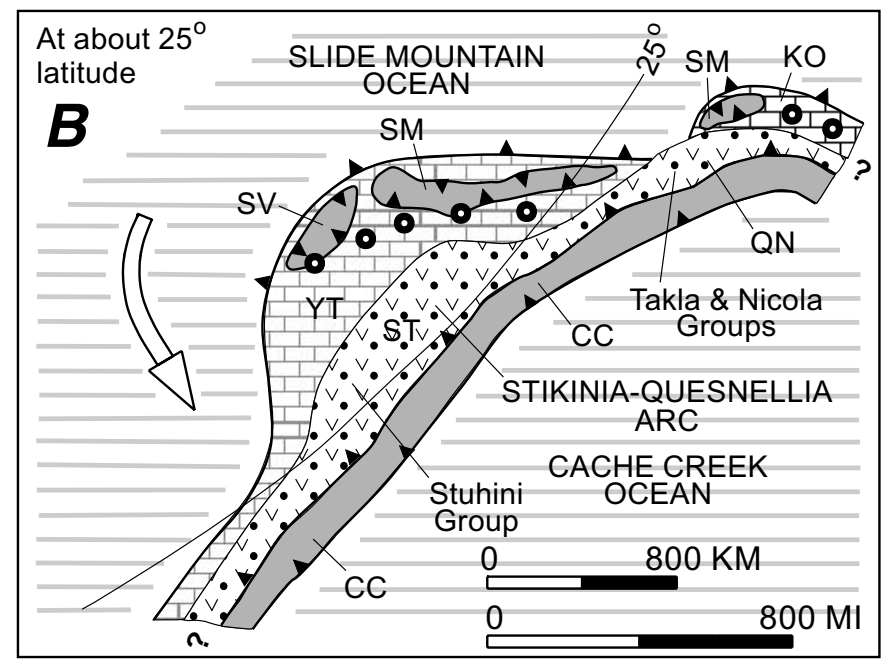

Figure 10.-Continued.
Stikinia-Quesnellia arc and associated terranes toward North America was accomplished by subduction and (or) obduction of the Seventymile oceanic plate along the continental margin.

6. The subduction-related volcanic and plutonic arc rocks of the Quesnellia part of the arc, consisting of the Takla and Rossland Groups, and coeval igneous belts formed in response to continued subduction of part of the Cache Creek oceanic plate (CC) (Mihalynuk and others, 1994). The Stikinia part of the arc consisted of the extensive suite of subduction-related volcanic and plutonic arc rocks of the Hazelton Group that also formed in response to subduction of the Cache Creek oceanic plate.

7. In the central part of the Stikinia-Quesnellia island arc, coeval subduction-related granitic plutonic rocks also intruded the previously accreted Yukon-Tanana passivecontinental-margin terrane (YT), which may have been the stratigraphic basement for part of the Stikinia island arc (Mihalynuk and others, 1994). These plutonic rocks also intruded the structurally overlying Slide Mountain (SM) and Seventymile (SV) terranes.

8. Also occurring was obduction of parts of the Seventymile and Slide Mountain oceanic plates onto the North American cratonal margin (NAM) (Mihalynuk and others, 1994). Part of the obduction occurred by the Late Triassic and (or) Early Jurassic, when granitic plutons of the Stikinia-Quesnellia island arc intruded across an intervening fault. During the final stage of obduction of the Slide Mountain terrane (SM) over the metamorphosed Kootenay continental-margin terrane (KO), these terranes started to be obducted onto the North American cratonal margin. Migration of the Stikinia-Quesnellia arc and associated terranes toward the North American cratonal margin was accomplished by subduction of the Seventymile oceanic plate along the continental margin and by obduction.

9. Outboard and, possibly, at a lower paleolatitude (either $25^{\circ}$ or $45^{\circ}$ ), the Talkeetna and Bonanza arcs continued activity in the Wrangellia superterrane (WRA). This extensive arc formed along most of the length of the Wrangellia superterrane, with coeval equivalents in the Cadwallader islandarc terrane (CD) and the Methow turbidite-basin terrane (MT). Associated with the Talkeetna and Bonanza arcs was subduction of part of the Cache Creek oceanic plate to form the Chugach (CG), Bridge River (BR), and, possibly, Baker (BA) terranes (table 2).

\section{Summary of Paleolatitude Data for the Hettangian Through Pleinsbachian}

For the Russian Far East, supporting paleolatitude data (table 3) are $72^{\circ}$ (grade C) for the Omolon terrane. For the Canadian Cordillera, paleolatitude data (table 3) supporting the southern-accretion interpretation for the Wrangellia superterrane are (1) $24^{\circ}$ (grade A) for the Bonanza group overlying the Wrangellia sequence of the Wrangellia superterrane in the central part of the Canadian Cordillera; (2) $19^{\circ}$ and $24^{\circ}$ 
(grade C) for the Copper Mountain and Tulameen units, respectively, in the Quesnellia terrane in the southern part of the Canadian Cordillera; and (3) nine values ranging from $28^{\circ}$ to $37^{\circ}$ (grades A, B, C) for the Topley intrusive rocks and the Telkwa Formation (eight localities) in the Stikinia terrane in the southern part of the Canadian Cordillera.
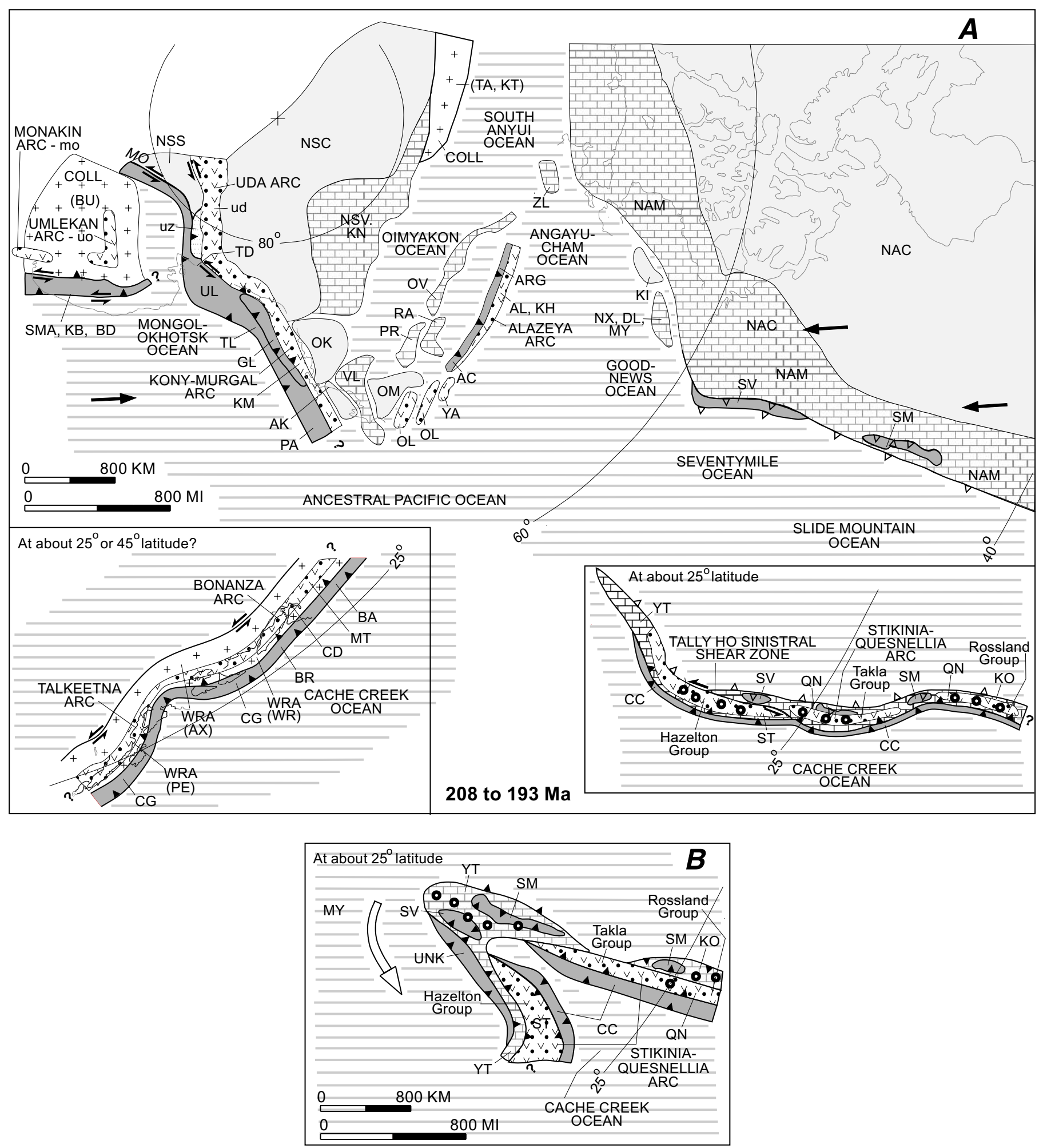

Figure 11.- Hettangian through Pliensbachian (208-193 Ma) stage of tectonic model. A, Tectonic model for the Circum-North Pacific. Insets show model for the Wrangellia supeterrane and model with continuing of strike-slip imbrication of the Stikinia-Quesnellia island-arc and related terranes. $B$, Alternative interpretation for tectonic evolution of the Stikinia-Quesnellia island-arc and related terranes, showing continuation of oroclinal warping. See text for explanation of tectonic events and figure 7 for explanation of abbreviations, symbols, and patterns. 


\section{Toarcian Through Callovian (193-163 Ma)}

During the Toarcian through Callovian (193-163 Ma), the major tectonic events were (1) continuation of continental-margin arcs and associated subduction near the North Asian Craton in the Russian Far East; (2) beginning of assembly of previously rifted cratonal, passive-continental-margin, and island-arc terranes between that craton and the ancestral Pacific Ocean to form the Kolyma-Omolon superterrane; (3) continuation of the Talkeetna, Bonanza, and Stikinia-Quesnellia arcs and formation of companion subduction zones (table 2); (4) continued sinistral-slip imbrication of the StikiniaQuesnellia island arc and associated subduction zones during oblique-sinistral convergence between the ancestral Pacific oceanic plate and the North American cratonal margin; and (5) with the beginning of accretion of the Stikinia-Quesnellia arc at about $185 \mathrm{Ma}$, the start of mountain building in the North American Cordillera. Sedimentation continued along the passive continental margins of the North Asian and North American Cratons.

\section{Specific Tectonic Events for the Toarcian Through Callovian}

1. The Monakin continental-margin arc, consisting of the Monakin volcanic-plutonic belt (mo), and the Umlekan continental-margin arc, consisting of the Umlekan-Ogodzhin volcanic-plutonic belt (uo) and associated units, commenced activity. Associated with this arc was oblique (sinistral) subduction of part of the ancestral Pacific oceanic plate to form the Samarka (SMA), Khabarovsk (KB), and Badzhal (BD) terranes (table 2).

2. The Uda continental-margin arc, consisting of the Uda volcanic-plutonic belt (ud) and the Uda-Zeya sedimentary basin (uz), continued to form. Associated with this arc was subduction and sinistral transpression of part of the Mongol-Okhotsk oceanic plate to form the TurkuringraDzhagdinski (TD), Ulban (UL), and Galam (GL) terranes (table 2). Subduction and sinistral transpression occurred along the Mongol-Okhotsk suture (MO).

3. The extensive Kony-Murgal island arc (Kony-Murgal terrane, $\mathrm{KM}$ ) continued to form as an offshore extension of the Uda arc. Associated with the arc was subduction of part of the ancestral Pacific oceanic plate to form the Talovskiy (TL) and Penzhina-Anadyr (PA) terranes (table 2). Inboard of the Kony-Murgal island arc were the Okhotsk (OK), Avekova (AK), and Omolon (OM) cratonal terranes, which were previously rifted from the North Asian Craton (NSC), and the Viliga (VL) passive-continental-margin terranes, which was previously rifted from the North Asian cratonal margin (NSV). Behind the arc were fragments of previous Devonian to Pennsylvanian island-arc terranes, including the Beryozovka turbidite-basin terrane (BE) and the Oloy (OL) and Yarakvaam (YA) island-arc terranes.

4. During the Bathonian, the Alazeya island arc, consisting of the Alazeya (AL) and Khetachan $(\mathrm{KH})$ island-arc terranes, as a result of flip of the associated subduction zone, migrated toward the terranes forming the Kolyma-Omolon superterrane. The southern part of the Kolyma structural loop was formed during the convergence of the Alazeya arc toward the terranes forming the Kolyma-Omolon superterrane. The major terranes in this superterrane are the Alazeya (AL), Aluchin (AC), Argatas (ARG), Beryozovka (BE), Khetachan (KH), Munilkan (MU), Oloy (OL), Omolon (OM), Omulevka (OV), Prikolyma (PL), Rassokha (RA), Uyandina (UY), and Yarakvaam (YM) terranes. During this collision, fragments of the older part of the Angayucham oceanic plate were obducted onto the Omulevka terrane to form the Munilkan (MU) ophiolite terrane and the Uyandina, Kybytygas, and Indigirka ophiolite terranes of Oxman and others (1995).

5. The Angayucham Ocean (Kobuck Sea of Plafker and Berg, 1994), along with the South Anyui Ocean, continued to receive sparse continental-derived detritus. Previously rifted terranes, including the Kilbuck-Idono cratonal terrane (KI) and the combined Nixon Fork-Dillinger-Mystic passive-continental-margin terrane (NX, DL, MY), continued to migrate toward the North American cratonal margin.

6. Dextral-slip imbrication of the Stikinia-Quesnellia arc and associated subduction-zone terranes was completed along the Tally Ho shear zone (Hansen and others, 1990; Hart, 1995). Alternatively, oroclinal warping of the StikiniaQuesnellia island-arc and associated subduction-zone terranes was completed (not shown in fig. 12; Mihalynuk and others, 1994). For either interpretation, migration of the Stikinia-Quesnellia arc and associated terranes toward North America was accomplished by subduction and (or) obduction of the Seventymile oceanic plate along the continental margin.

7. Also completed was obduction of parts of the Seventymile and Slide Mountain oceanic plates onto the North American cratonal margin (NAM) (Mihalynuk and others, 1994). Migration of the Stikinia-Quesnellia arc and associated terranes toward the North American cratonal margin was accomplished by subduction of the Seventymile oceanic plate along the continental margin and by obduction.

8. The subduction-related volcanic and plutonic arc rocks of the Quesnellia part of the arc, consisting of the Takla Group, and coeval igneous belts formed in response to continued subduction of part of the Cache Creek oceanic plate (CC) (Mihalynuk and others, 1994). The Stikinia part of the arc consisted of the extensive suite of subductionrelated volcanic and plutonic arc rocks of the Hazelton Group that also formed in response to subduction of part of the Cache Creek oceanic plate. Remnants of this oceanic plate may be preserved in the terrane of ultramafic and related rocks that occurs discontinuously along the Denali strike-slip fault (DE, fig. 20) for several hundred kilometers (Nokleberg and others, 1994b).

9. Outboard and, possibly, at a lower paleolatitude (either $25^{\circ}$ or $45^{\circ}$ ), the Talkeetna and Bonanza arcs continued activity in the Wrangellia superterrane (WRA). This extensive arc formed along most of the length of the Wrangellia superterrane, with coeval equivalents in the Cadwallader island-arc terrane (CD) and the Methow tur- 
bidite-basin terrane (MT). Associated with the Talkeetna and Bonanza arcs was subduction of part of the Cache Creek oceanic plate to form the Chugach (CG), Bridge River (BR), and, possibly, Baker (BA) terranes (table 2).

\section{Summary of Paleolatitude Data for the Toarcian Through Callovian}

For the Russian Far East, supporting paleolatitude data (table 3) are $72^{\circ}$ (grade C) for the Omolon terrane. For the Canadian Cordillera, paleolatitude data (table 3 ) supporting the southern-accretion interpretation for the Wrangellia superterrane are (1) $24^{\circ}$ (grade A) for the Bonanza group overlying the Wrangellia sequence of the Wrangellia superterrane in the central Canadian Cordillera; (2) $19^{\circ}$ and $24^{\circ}$ (grade C) for the Copper Mountain and Tulameen units, respectively, in the Quesnellia terrane in the southern part of the Canadian Cor- dillera; and (3) nine values ranging from $28^{\circ}$ to $37^{\circ}$ (grades A, B, C) for the Topley intrusive rocks and the Telkwa Formation (eight localities) in the Stikinia terrane in the southern part of the Canadian Cordillera.

\section{Oxfordian Through Kimmeridgian (163-144 Ma)}

During the Oxfordian through Kimmeridgian (163-144 $\mathrm{Ma}$ ), the major tectonic events were (1) beginning of accretion of the Bureya superterrane (BU) against the North Asian Craton along the Mongol-Okhotsk suture, thereby closing the Mongol-Okhotsk Ocean; (2) establishment of a series of continental-margin arcs and companion subduction-zone assemblages around the Circum-North Pacific (table 2); (3) initiation of rift grabens that subsequently formed the presentday Amerasia and Canada Basins; and (4) ending of the previous long-lived period (Late Proterozoic through Early

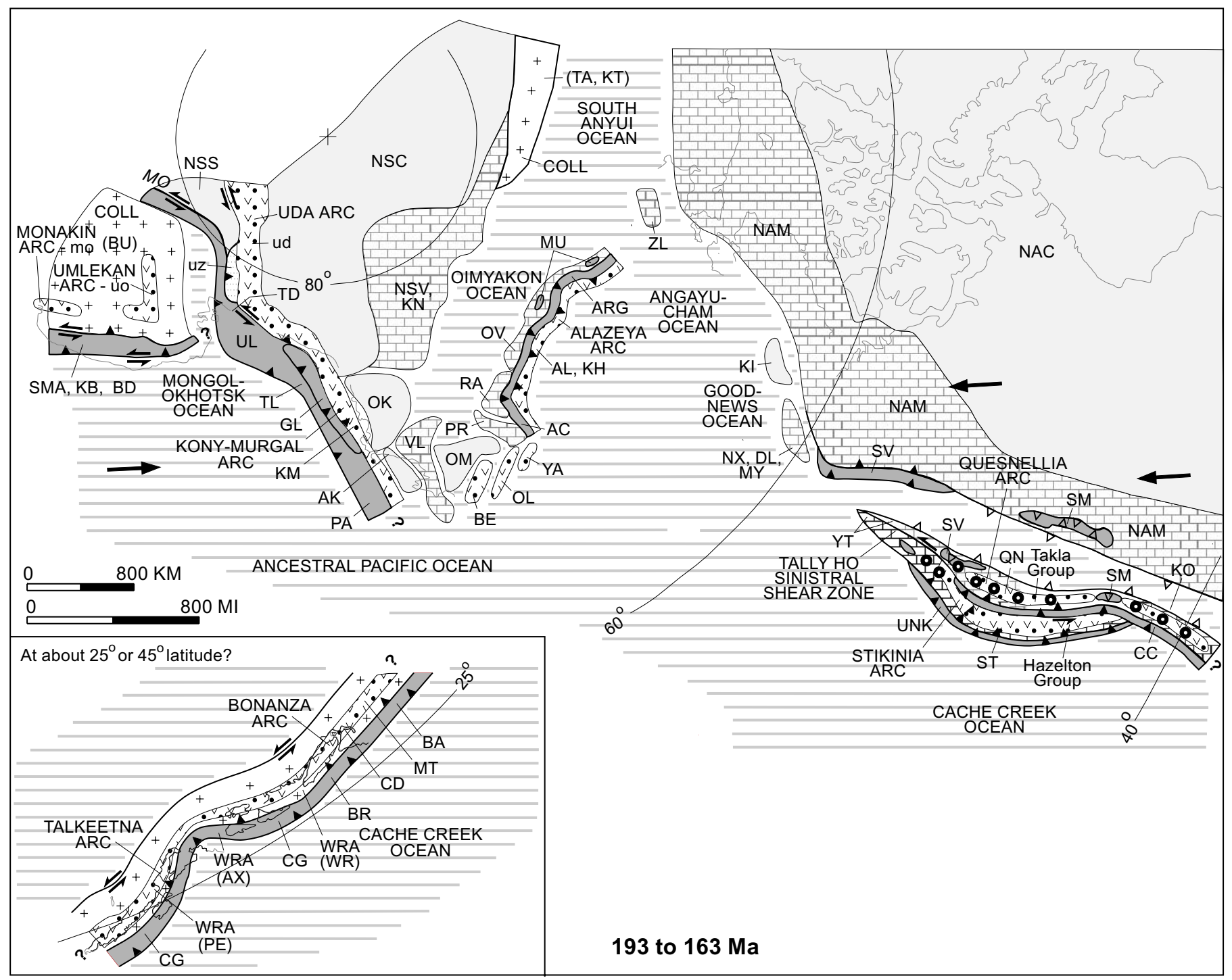

Figure 12.-Toarcian through Callovian (193-163 Ma) stage of tectonic model. See text for explanation of tectonic events and figure 7 for explanation of abbreviations, symbols, and patterns. 
Jurassic) of passive sedimentation along the North Asian and North American cratonal margins.

\section{Specific Tectonic Events for the Oxfordian Through Kimmeridgian}

1. Far to the south at about $60^{\circ}$ paleolatitude, the Mainitskiy island arc (Mainitskiy terrane, MAI) commenced activity. Tectonically linked to this arc was the Alkatvaam accretionary-wedge terrane (AV), which formed from subduction of part of the adjacent oceanic plate. The arc and companion subduction zone migrated northward toward the Kony-Murgal island arc (KM).

2. The Monakin arc (Monakin volcanic-plutonic belt, mo) and the Umlekan arc (Umlekan-Ogodzhin volcanic-plutonic belt, uo and associated units) continued activity. Associated with these arcs was oblique (sinistral) subduction of part of the ancestral Pacific oceanic plate to continue forming the Samarka (SMA), Khabarovsk $(\mathrm{KB})$, and Badzhal (BD) terranes (table 2). In the same region, the Bureya superterrane (BU) accreted against the Ulban accretionary-wedge terrane (UL) along the Mongol-Okhotsk suture (MO), thereby closing the MongolOkhotsk Ocean.

3. The Uda continental-margin arc (Uda volcanic-plutonic belt [ud] and Uda-Zeya sedimentary basin [uz]) continued to form. Associated with this arc was subduction and sinistral transpression of part of the Mongol-Okhotsk oceanic plate to form the Turkuringra-Dzhagdinsk (TD) and Ulban (UL) terranes (table 2). Subduction was associated with sinistral transpression along the Mongol-Okhotsk suture (MO).

4. The extensive Kony-Murgal continental-margin and island-arc terrane (KM) continued to form as an extension of the Uda continental-margin arc (ud). Associated with this arc was continued subduction of part of the ancestral Pacific oceanic plate to form the Talovskiy (TL) and Penzhina-Anadyr (PA) terranes (table 2). The Kony-Murgal island arc overlapped the Okhotsk (OK) and Avekova (AK) cratonal terranes, which was previously rifted from the North Asian Craton (NSC), and the Viliga (VL) passive-continental-margin terrane, which was previously rifted from the North Asian cratonal margin (NSV). As a transform extension of the Kony-Murgal terrane, the West Pekul'ney island-arc terrane (WP) was initiated. Associated with this arc was subduction of part of the ancestral Pacific plate to form the Pekul'ney terrane (PK).

5. The Kolyma-Omolon superterrane (KLO) continued to migrate toward the North Asian cratonal margin (NSV). During migration, the Uyandina arc (consisting of the Uyandina-Yasachnaya volcanic belt in the western part of the long Indigirka-Oloy sedimentary-volcanic-plutonic assemblage, io) started to form along the leading edge of this superterrane. Associated with the Uyandina arc was subduction of the oceanic-crustal rocks preserved in the Garbyn'ya (GA) and Debin (DB) ophiolite belt (and corresponding terranes, fig. 1) of Oxman and others (1995) that are herein interpreted as remnants of the Oimyakon oceanic plate (table 2 ).

6. On the opposite side of the Kolyma-Omolon superterrane (KLO), the Oloy island arc (ol) formed in response to subduction of part the South Anyui oceanic plate. Along one part of the North Asian cratonal margin (NSV), the Svyotov Nos continental-margin arc formed along the margin of the Taymyr Peninsula collage (TA) in response to subduction of another part of the South Anyui oceanic plate to form the South Anyui subduction-zone terrane (SA). The Angayucham Ocean continued to exist along with the South Anyui Ocean.

7. Adjacent to the North American cratonal margin (NAM), two extensive arcs formed. The Nutesyn continental-margin arc formed in response to subduction of part of the South Anyui oceanic plate to form the Velmay subductionzone terrane (VE). The Koyukuk (KY), Togiak (TG), and Nyac (NY) island-arc terranes formed in response to subduction of an (inner) Angayucham oceanic plate to extend the Angayucham subduction-zone terrane (AG) (table 2). Locally substantial terrigenous detritus in Jurassic turbidite deposits in the lower structural part of the Angayucham terrane (Slate Creek subterrane of Moore and others, 1994b) may have been derived from erosion of the North American cratonal margin (Moore and others, 1994b). The polarity of the island arc was continentward, toward the North American cratonal margin. Outboard of the island arc were the (outer) Angayucham and Goodnews Oceans. The Kilbuck-Idono cratonal terrane (KI) and the combined Nixon Fork-Dillinger-Mystic passive-continental-margin terrane (NX, DL, MY) were accreted onto the North American cratonal margin at about the same time as obduction of the Stikinia-Quesnellia island arc, as described below.

8. Rift grabens, depicted as rifting associated with sea-floor spreading, began to open the present-day Amerasia and Canada Basins (Grantz and others, 1998). These grabens were an early stage of creation of new oceanic crust during the Early Cretaceous, as described below.

9. A subduction zone (UNK) with a component of sinistral slip is inferred to have formed along and parallel to the continental margin in order to accomplish migration of the Wrangellia superterrane toward the North American cratonal margin. Remnants of this subduction zone may be preserved in the terrane of ultramafic and related rocks that occurs discontinuously along the Denali strike-slip fault (DE, fig. 20) for several hundred kilometers (Nokleberg and others, 1994b). The mafic and ultramafic rocks may in part be derived from the Farallon oceanic plate (FAR) that separated the Wrangellia superterrane from the North American cratonal margin.

10. Regional thrust faulting occurred, with obduction of the Stikinia (ST), Quesnellia (QN), Cache Creek (CC), Slide Mountain (SM), Yukon-Tanana (YT), and Kootenay (KO) terranes over the Cassiar (CA) terrane and the North American cratonal margin (NAM). This compressional event marked the beginning of a major orogenic event, including regional metamorphism, deformation, crustal 
thickening, anatectic magmatism, and uplift in the core of the present-day Canadian Cordillera (Monger and Nokleberg, 1996). The Nelson plutonic suite (ns), which intrudes the Stikinia, Quesnellia, Kootenay, Cache Creek, and Slide Mountain terranes, formed during this compressional event. The Nelson plutonic suite consists chiefly of granodiorite, quartz monzonite, and local monzonite plutons that yield isotopic ages mainly of 155 to 185 Ma, with local crustal inheritance (Parrish and others, 1988; Woodsworth and others, 1992). By the Late Jurassic (approx $155 \mathrm{Ma}$ ), detritus from this emergent orogenic welt in the eastern part of the Canadian Cordillera was shed eastward onto the North American cratonal margin (Cant, 1989).

11. The extensive Gravina island arc was initiated along the length of the Wrangellia superterrane. Remnants of this arc are preserved in the Kahiltna (kh) and Gravina-Nutzo-
tin-Gambier (gg) assemblages, which occur only in the Wrangellia superterrane. Associated with the arc was subduction of part of the Farallon oceanic plate (FAR) to form the Chugach (CG), Bridge River (BR), Easton (EA), and Baker (BA) terranes (table 2).

\section{Summary of Paleolatitude Data for the Oxfordian Through Kimmeridgian}

For the Russian Far East, conflicting paleolatitude data (table 3 ) are (1) $39^{\circ}$ (grade A) for the Indigirka-Oloy assemblage overlying the Omolon terrane, (2) $62^{\circ}$ and $69^{\circ}$ (grade A) for the Omulevka terrane, and (3) $65^{\circ}$ (grade B) for the Viliga terrane. The values for the Omulevka and Viliga terranes, however, have 95-percent-confidence limits that include $90^{\circ}$. For Alaska, paleolatitude data (table 3 ) supporting the

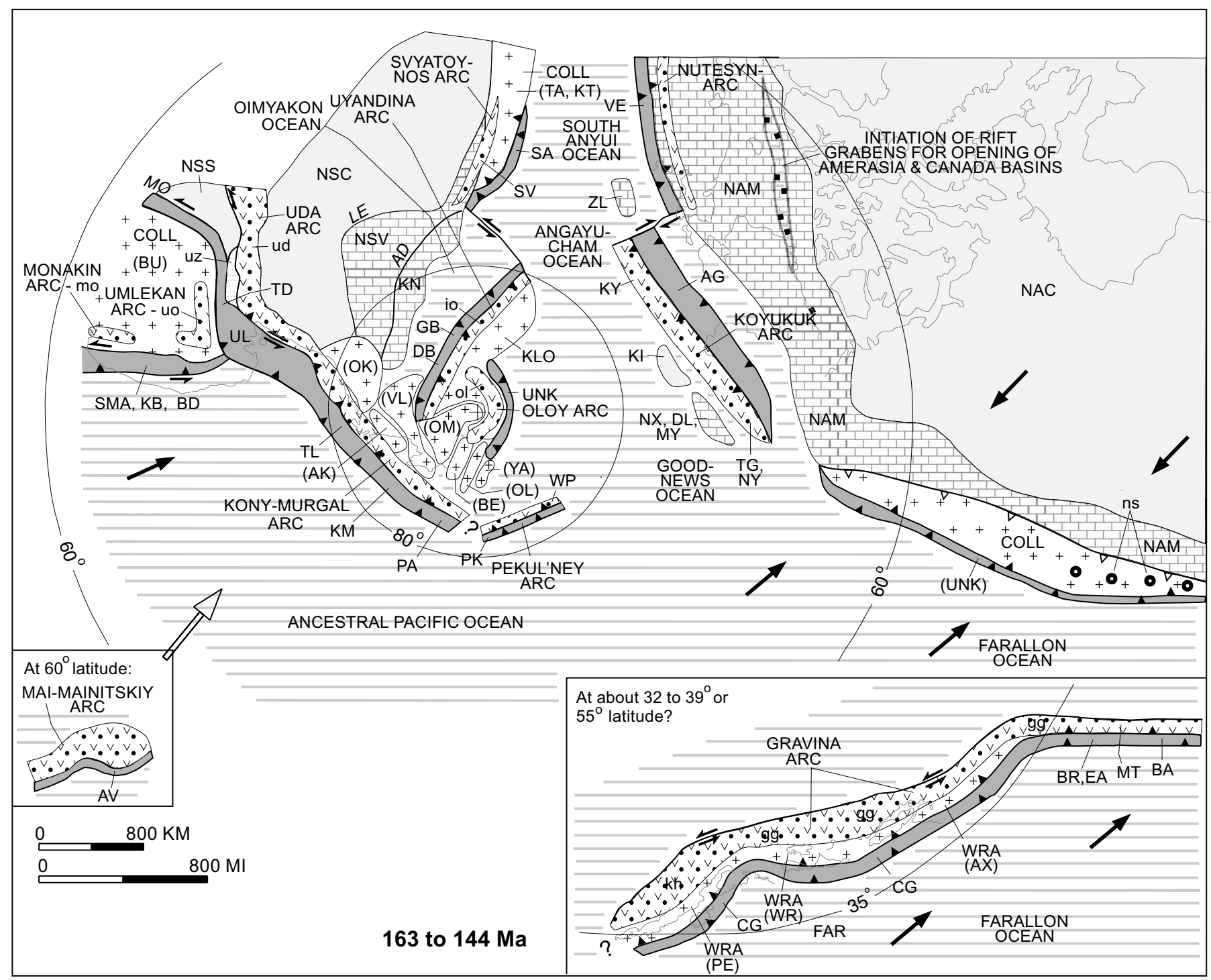

Figure 13.- Oxfordian through Kimmeridigian (163-144 Ma) stage of tectonic model. See text for explanation of tectonic events and figure 7 for explanation of abbreviations, symbols, and patterns. 
southern-accretion interpretation for the Wrangellia superterrane are (1) $32^{\circ}$ (grade B) for the Naknek/Chitina units in the Peninsular sequence of the Wrangellia superterrane and (2) $39^{\circ}$ (grade C) for the Westcoast Complex in the Wrangellia sequence of the Wrangellia superterrane.

\section{Neocomian (144-120 Ma)}

During the Neocomian (144-120 Ma), the major tectonic events were (1) completion of accretion of the Bureya superterrane against the North Asian Craton along the MongolOkhotsk suture and formation of associated metallogenic belts; (2) continuation of the continental-margin and island arcs and companion subduction-zone assemblages around the Circum-North Pacific (table 2); (3) accretion of the major Kolyma-Omolon superterrane in the Russian Northeast; (4) initiation of obduction of the Angayucham subduction-zone terrane onto the North American continental margin; (5) continuation of opening of the Amerasia, Canada, and Eurasia Basins in response to sea-floor spreading in the Arctic Ocean; (6) beginning of accretion of the Wrangellia superterrane in the southern part of the Canadian Cordillera (northern-accretion interpretation); and (7) around the Circum-North Pacific, continued sinistral transpression between oceanic plates and continents.

\section{Specific Tectonic Events for the Neocomian}

1. Far to the south at about $32^{\circ}$ paleolatitude (table 3 ), the Mainitskiy island arc (Mainitskiy terrane, MAI) commenced activity. Associated with this arc was subduction of part of the adjacent oceanic plate to form the Alkatvaam accretionary-wedge terrane (AV) (table 2). This arc and companion subduction zone migrated northward toward the Kony-Murgal island arc.

2. The Umlekan arc (Umlekan-Ogodzhin volcanic-plutonic belt [uo] and associated units) continued activity. Associated with this belt was subduction of part of the ancestral Pacific oceanic plate to form the Amur (AM) and Badzhal (BD) terranes (table 2).

3. The Uda continental-margin arc (Uda volcanic-plutonic belt, ud, and Uda-Zeya sedimentary basin, uz) continued to form. Associated with the arc was subduction and sinistral transpression of the final remnant of the Mongol-

Okhotsk oceanic plate, thereby forming the Ulban terrane (UL). Sinistral transpression continued along the MongolOkhotsk suture (MO).

4. The extensive Kony-Murgal continental-margin and island arc and the Pekulney island arc continued to form. Associated with these arcs was subduction of part of the ancestral Pacific oceanic plate to form the Talovskiy (TL), Penzhina-Anadyr (PA), and Pekulney (PK) terranes (table 2).

5. Behind the Kony-Murgal arc, the Kolyma-Omolon superterrane (KLO) was accreted between at about 140 to 100 Ma. During the early stage of accretion, the Main col- lisional granite belt (ma) (144-134 Ma) formed (Layer and others, 1995; Fujita and others, 1997). At about the final stage of accretion, the subduction-related Northern collisional granite belt (no) formed at about 127 to 120 Ma (Fujita and others, 1997). In contrast to the Main granite belt, the coeval Northern collisional granite belt is interpreted as having formed in response to subduction related to closure of an inlet of the South Anyui Ocean. As a result, the northern bend of the Kolyma-Omolon structural loop formed (Sengör and Natal'in, 1996a). As a continuation of this structural loop, the extensionrelated Transverse granite belt (tr) formed (Parfenov, 1991, 1995c).

6. The Oloy island arc and opposing Nutesyn and Koyukuk island arcs continued to be active on opposite sides of the South Anyui and Angayucham Oceans. Parts of these arcs are preserved in the Nutesyn (NU), Koyukuk (KY), Togiak (TG), and Nyac (NY) terranes. Associated with these arcs was subduction of parts of the South Anyui and Angayucham oceanic plate, thereby forming the South Anyui (SA), Velmay (VE), and (inner) Angayucham (AG) terranes, and subduction of the outboard margin of the Arctic Alaska terrane. An extensive zone of blueschistfacies metamorphism occurs in this region in both the Angayucham and Arctic Alaska terranes. The polarity of the Koyukuk, Togiak, and Nyac island arcs was oceanward, away from the North American passive continental margin (Arctic Alaska superterrane, AA). After initial accretion of the Koyukuk arc to the Arctic Alaska superterrane, beginning in the Late Jurassic at about 160 to $145 \mathrm{Ma}$ (Moore and others, 1994a, b), subduction flipped to outboard of the new continental margin in this part of present-day Alaska.

7. At about 140 to $135 \mathrm{Ma}$, sea-floor spreading and associated rifting, which started with the formation of grabens in the Late Jurassic or earlier (Grantz and others, 1990, 1991, 1998; Lawver and Scotese, 1990), formed (1) new oceanic crust and the large proto-Amerasia (ab) and proto-Canada (cb) basins, and (2) a collage of passive-continental-margin terranes derived from the North American cratonal margin (Artis Plateau [AP], Chukchi Cap [CK], Chukchi Spur [CS], and Northwind Ridge [NR] terranes). Sea-floor spreading and opening of the Amerasia and Canada Basins is herein interpreted as causing (1) closure of the inner Angayucham Ocean; (2) subduction of the North American continental margin (Chukotka terrane $[\mathrm{CH}]$ and Arctic Alaska superterrane [AA]); (3) beginning of closure of the South Anyui Ocean; (4) intense deformation and metamorphism of the southern margin of the eastern Chukotka terrane $(\mathrm{CH})$ and southern Arctic Alaska superterrane (AA) to form the Seward (SD), Coldfoot (CO), and Ruby (RB) terranes; (5) formation of an extensive blueschist-facies belt in both the subducted continental margin (Arctic Alaska superterrane [AA] and Seward [SD], Coldfoot [CO], and Ruby [RB] terranes) and the overthrust Angayucham terrane (AG); and (6) deposition of synorogenic Early Cretaceous to mid-Cretaceous flysch in the Koyukuk Basin in what became present-day western 
Alaska. For additional information on the details of opening of the Canada Basin, whether by rifting and rotation or by strike-slip translation, or by a combination of these two processes, see the analyses by Grantz and others (1990, 1998) and Lane (1994, 1997).

8. Underthrusting in a subduction zone along the North American cratonal margin (NAM) resulted in consumption of the Farallon oceanic plate (FAR). Small tectonic lenses of terranes of alpine ultramafic and related rocks along the ancestral Denali Fault (see fig. 17; Nokleberg and others, 1985, 1994a) may be remnants of the subduction-zone assemblages that may have been mostly thrust under the margin of present-day North America.

9. The Gravina arc continued to form. Associated with the Gravina arc was subduction of part of the Farallon oceanic plate to form the Chugach (CG), Bridge River (BR),
Easton (EA), and Baker (BA) terranes. Part of this arc was preserved in the Kahiltna (kh) and Gravina-NutzotinGambier (gg) assemblages, which occur only in the Wrangellia superterrane.

10. The Wrangellia superterrane (WRA) started to accrete at about $60^{\circ}$ paleolatitude (northern-accretion interpretation), with the continentward part of the Wrangellia superterrane impinging onto a collage of terranes previously accreted to the North American cratonal margin (NAM). With accretion, the arc extended southward with the formation of two major overlap assemblages: the coeval Tahtsa-Three Sisters magmatic assemblage (tt) and the Spences Bridge volcanic-plutonic belt (sb). Alternatively, the Wrangellia superterrane was far to the south at about $35^{\circ}$ paleolatitude (southern-accretion interpretation; see inset, fig. 14).

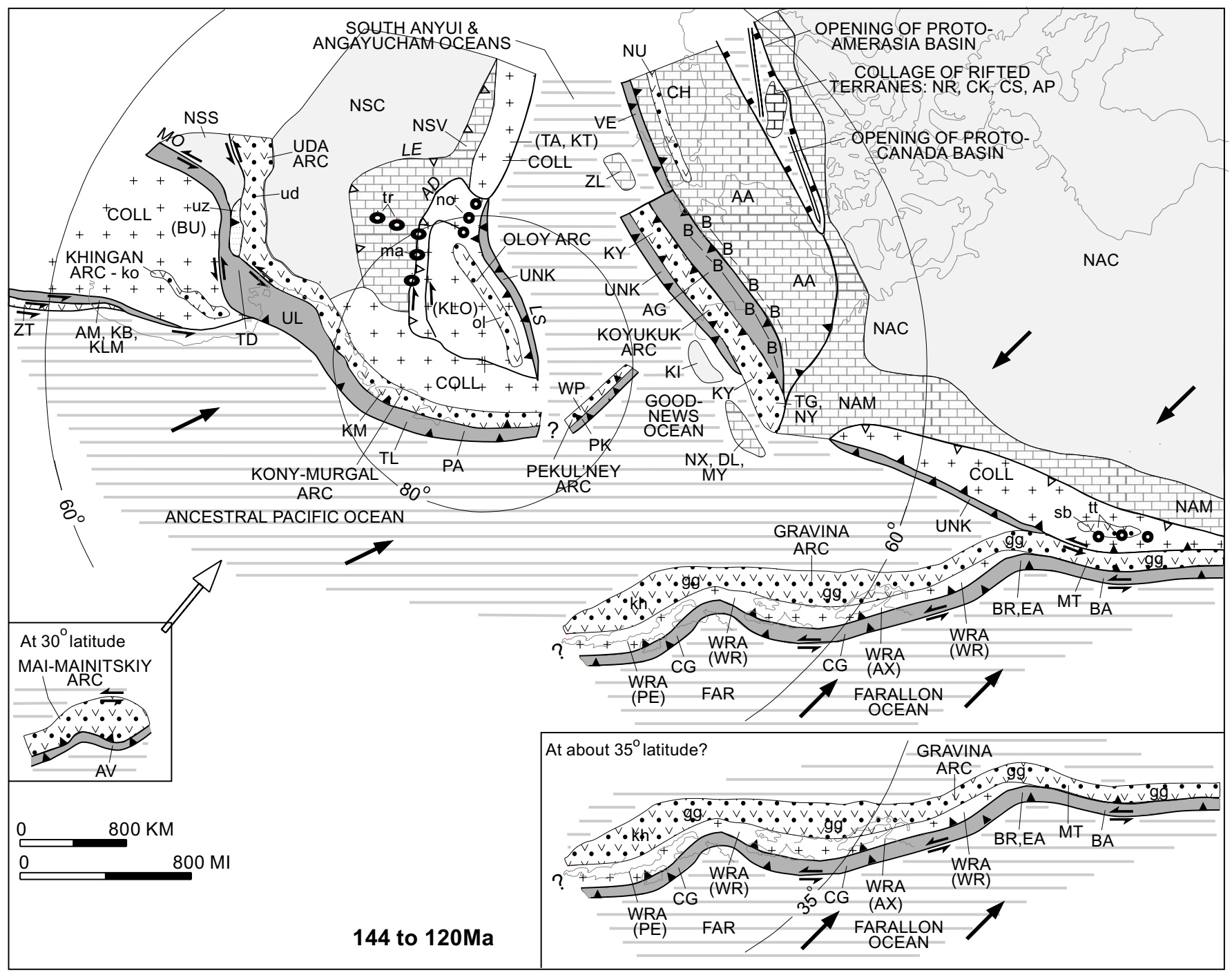

Figure 14.-Neocomian (140-120 Ma) stage of tectonic model. See text for explanation of tectonic events and figure 7 for explanation of abbreviations, symbols, and patterns. 


\section{Summary of Paleolatitude Data for the Neocomian}

For the Russian Far East, supporting paleolatitude data (table 3) are (1) $32^{\circ}$ (grade A) for the Mainitskiy terrane, (2) $76^{\circ}$ (grade C) for the Khetachan terrane, and (3) $88^{\circ}$ (grade C) for the Eropol subterrane of the Oloy terrane. Conflicting paleolatitudes for the Russian Far East (table 3) are (1) $62^{\circ}$ (grade C) for a locality at Penzhino Gulf in the Talovskiy terrane and (2) $74^{\circ}$ (grade C) for the Alkatvaam terrane.

For Alaska and the Canadian Cordillera, supporting paleolatitude data (table 3) are (1) $69^{\circ}$ and $74^{\circ}$ (grade B) for the Nanushuk Group and Kaparuk River Formation overlying the North Slope subterrane of the Arctic Alaska terrane, (2) $69^{\circ}$ (grade A) for another locality (Melozitna quadrangle) in the Koyukuk terrane, (3) $62^{\circ}$ and $67^{\circ}$ (grade A) for two more localities (Melozitna and Nulato quadrangles, respectively) in the Koyukuk terrane, and (4) $53^{\circ}$ (grade B) for the Axelgold pluton intruding the northern part of the Cache Creek terrane. The paleolatitude for the Axelgold pluton supports the northern-accretion interpretation for the Wrangellia superterrane. Paleolatitude data (table 3) supporting the southernaccretion interpretation for the Wrangellia superterrane are $36^{\circ}$ (grade B) for the Duke Island ultramafic complex that is part of the Gravina-Nutzotin-Gambier overlap assemblage in southeastern Alaska.

\section{Aptian Through Albian (120-100 Ma)}

During the Aptian through Albian (120-100 Ma), the major tectonic events were: (1) inception of the short-lived Khinghan continental-margin arc and companion subduction zone in the Russian Southeast (table 2); (2) accretion of the Mainitskiy island arc and associated Alkatvaam (AV) accretionary-wedge terranes to the active continental margin by the beginning of the Albian; (3) completion of accretion of the major Kolyma-Omolon superterrane in the Russian Northeast; (4) obduction of Angayucham subduction-zone terrane onto

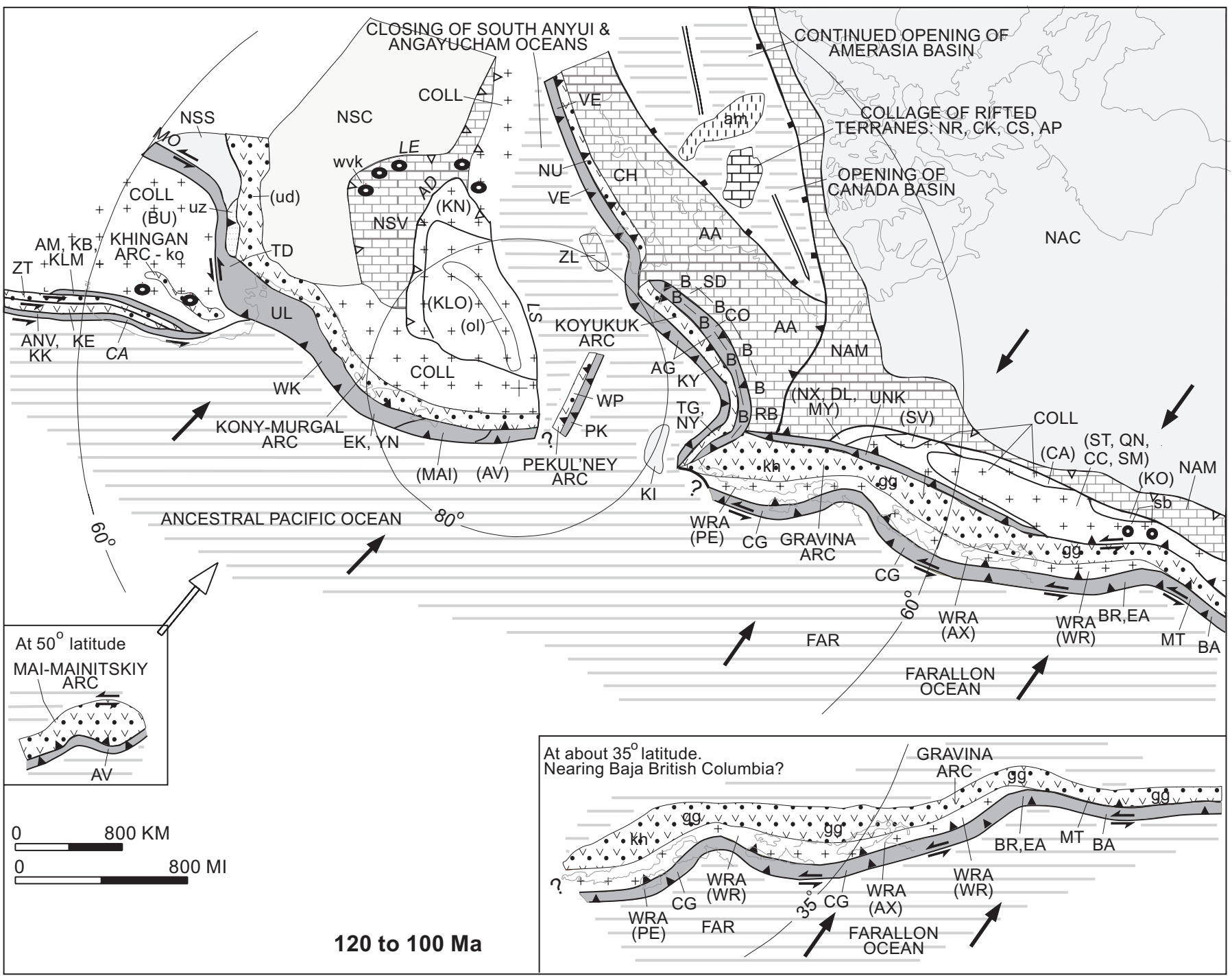

Figure 15.-Aptian through Albian (120 to $100 \mathrm{Ma}$ ) stage of tectonic model. Refer to text for explanation of tectonic events and to figure 7 for explanation of abbreviations, symbols, and patterns. 
the Arctic Alaska terrane (rifted fragment of North American Continental Margin); (5) continued opening of the Amerasia, Canada, and Eurasia Basins; and (6) continuing accretion of the Wrangellia superterrane.

\section{Specific Tectonic Events for the Aptian Through Albian}

1. At about $50^{\circ}$ paleolatitude, the Mainitskiy island arc (Mainitskiy terrane, MAI) continued activity. Associated with this arc was subduction of part of the adjacent oceanic plate to form the Alkatvaam accretionary-wedge terrane (AV) (table 2). This arc and companion subduction zone continued to migrate northward toward the North Asian cratonal margin and outboard terranes, and was accreted to the active continental margin by the beginning of the Albian, when deposition of the overlying Kuibiveem sedimentary assemblage $(\mathrm{kb})$ commenced. The Kuibiveem assemblage (included in unit oc, fig. 3) is interpreted as a forearc unit to the Okhotsk-Chukotka continental-margin arc (oc). Subduction stepped outboard during this accretion.

2. At the end of the Neocomian, oblique subduction was replaced by sinistral-slip faulting parallel to the continental margin. This faulting resulted in structural interleaving of the previously active subduction-zone terranes. This structural interleaving is interpreted as similar to the present-day region of southern California and resulted in formation of the fault-bounded basin of marine turbidites now preserved in the Zhuravlesk-Tumnin turbidite-basin terrane (ZT) (Golozubov and Khanchuk, 1996).

3. The Khingan continental-margin arc (ko) started to form. Associated with this arc was oblique subduction of part of the ancestral Pacific oceanic plate to form the Amur River (AM), Khabarovsk (KB), and Kiselevka-Manoma (KLM) terranes (table 2).

4. The Uda continental-margin arc and associated subduction zones ceased activity with accretion of the Bureya superterrane and closure of the Mongol-Okhotsk Ocean along the Mongol-Okhotsk suture (MO).

5. The extensive Kony-Murgal continental-margin and island arc and the Pekulney island arc continued to form. Associated with these arcs was subduction of part of the ancestral Pacific oceanic plate to form the Talovskiy (TL), Penzhina-Anadyr (PA), and Pekulney (PK) terranes (table 2).

6. The final stages of accretion of the Kolyma-Omolon superterrane is interpreted as causing a second phase of deformation in the Verkhoyansk fold-and-thrust belt and formation of the West Verkhoyansk collisional granite belt (wk) (120-90 Ma) along the Lena Fault (LE).

7. The Nutesyn and Koyukuk island arcs continued activity on opposite sides of the South Anyui and Angayucham Oceans. Parts of these arcs are preserved in the Nutesyn (NU), Koyukuk (KY), Togiak (TG), and Nyac (NY) terranes. Associated with the arcs were subduction of parts of the South Anyui and Angayucham oceanic plates to form the Velmay (VE) and (outer) Angayucham (AG) terranes, and subduction of the outboard margin of the Arctic Alaska terrane. An extensive zone of blueschistfacies metamorphism occurs in this region in both the Angayucham and Arctic Alaska terranes.

8. In the Arctic, sea-floor spreading and associated rifting continued with the formation of large sedimentary basins and the creation of a collage of passive-continental-margin terranes derived from the North American cratonal margin (NAM) (Grantz and others, 1990, 1991, 1998; Lawver and Scotese, 1990). Continuing was closure of the Angayucham Ocean, subduction along the North American continental margin, intense thrusting in the passive-continental-margin terranes, and deposition of Early Cretaceous to mid-Cretaceous flysch.

9. On the edge of the Wrangellia superterrane (WRA), the Gravina arc continued to form. Associated with this arc was subduction of part of the Farallon oceanic plate to form the Chugach (CG), Bridge River (BR), Easton (EA), and Baker (BA) terranes. Part of the arc was preserved in the Kahiltna (kh) and Gravina-Nutzotin-Gambier (gg) assemblages, which occur only in the Wrangellia superterrane. The Gravina arc extended into the southern part of the Canadian Cordillera with the formation of the Spences Bridge volcanic-plutonic belt (sb).

10. The central and northern parts of the Wrangellia superterrane (WRA) accreted to the northern part of the Canadian Cordillera and southern Alaska (northern-accretion interpretation). Along the accreting edge of the superterrane, the intervening oceanic plate and the Kahiltna overlap assemblage were thrust during the active continental margin of southern Alaska and the northern part of the Canadian Cordillera (Stanley and others, 1990). The small tectonic lenses of terranes of alpine ultramafic and related rocks along the ancestral Denali Fault (UM) (Nokleberg and others, 1985, 1994a) may be remnants of this oceanic lithosphere. Coeval with accretion of the Wrangellia superterrane was intrusion of the Omineca-Selwyn anatectic granite belt (om) that occurs along the length of the Canadian Cordillera and Alaska. Alternatively, the Wrangellia superterrane was far to the south at about $35^{\circ}$ paleolatitude (southern-accretion interpretation; see inset, fig. 15).

Summary of Paleolatitude Data for the Aptian Through Albian

Paleolatitude data for the Aptian through Albian (late Early Cretaceous) are summarized with other paleolatitude data in the preceding subsection for the Neocomian.

\section{Cenomanian Through Santonian (100-84 Ma)}

During the Albian though Santonian (100-84 Ma), the major tectonic events were (1) establishment of a series of continental-margin arcs and companion subduction-zone 
assemblages almost continuously around the Circum-North Pacific (table 2); (2) continued opening of an ocean that would become the Amerasia, Canada, and Eurasia Basins; (3) completion of accretion of the Wrangellia superterrane (northern-accretion interpretation); and (4) in the eastern part of the Circum-North Pacific, a change to orthogonal compression between the Farallon oceanic plate and North America.

\section{Specific Tectonic Events for the Cenomanian Through Santonian}

1. At about $32^{\circ}-60^{\circ}$ paleolatitude, the Olyutorka island arc commenced activity (table 3 ). Parts of this arc are preserved in the Nemuro (NE), Kronotskiy (KRO), Olyutorka-Kamchatka (OKA), Iruneisky (IR), Shmidt (SHT), and Terpeniya (TR) terranes. Associated with the arc was subduction of part of adjacent oceanic plate to form the Vetlovskiy (VT) terrane (table 2). This arc and com- panion subduction zone migrated northward toward the Okhotsk-Chukotka continental-margin arc.

2. The East Sikhote-Alin continental-margin arc (es) was initiated. This major Andean-type arc overlapped previously accreted adjacent terranes in both the Russian Southeast and to the south. The arc extended for more than $1,600 \mathrm{~km}$ along the active Russian Southeast continental margin. Forming as part of the arc was the West Sakhalin (WSA) turbidite-basin terrane. Associated with the arc was oblique subduction of part of the ancestral Pacific oceanic plate (PAC) to form the Hidaka (HI), Aniva (ANV), and Nabilsky (NAB) terranes (table 2).

3. The Khingan continental-margin terrane (ko) continued activity.

4. Subduction stepped seaward, after the accretion of the Mainitskiy arc, with the consequent inception of the Okhotsk-Chukotka continental-margin arc (oc) and related Penzhina (forearc) sedimentary basin (pn) along the new continental margin. This major Andean-type

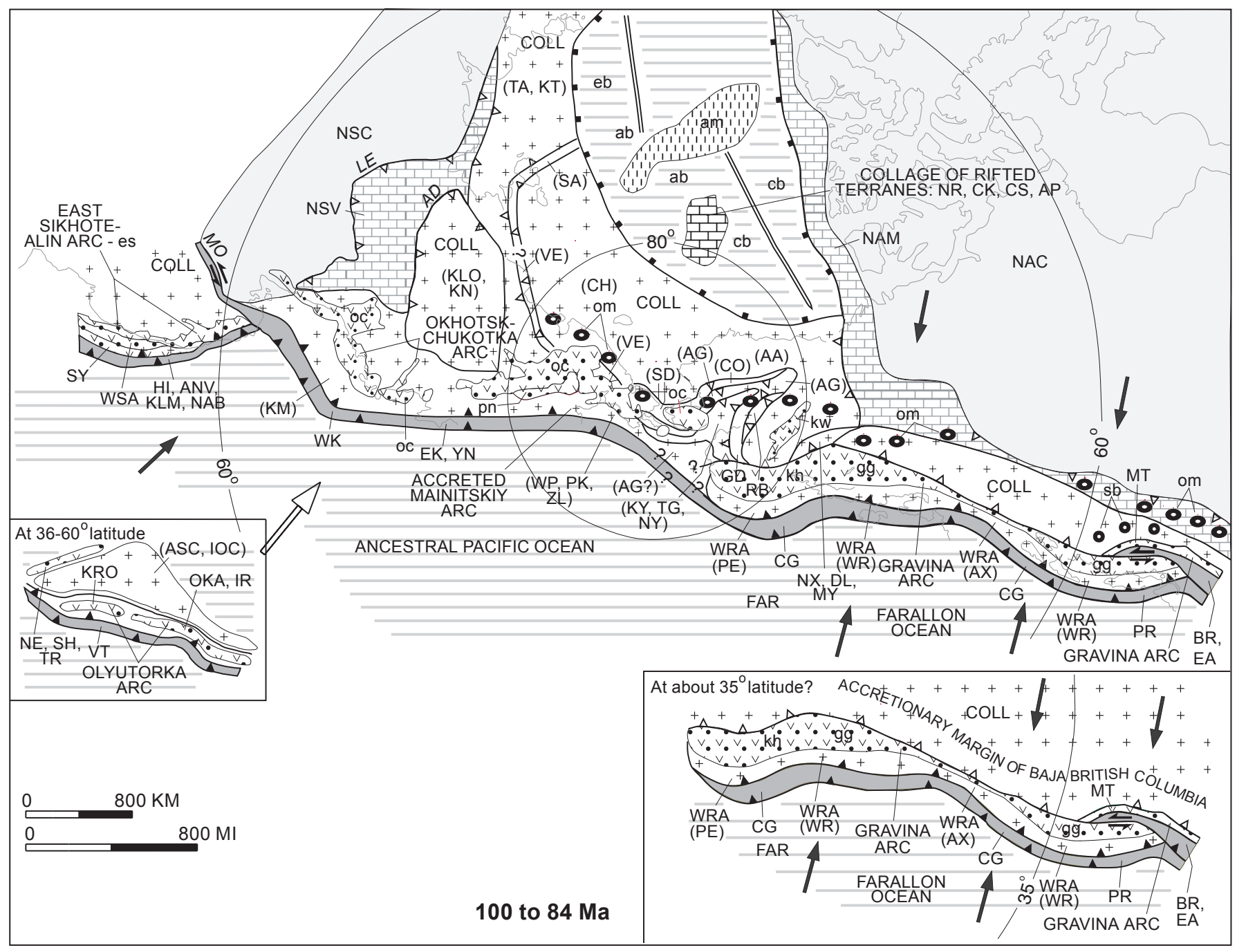

Figure 16.-Cenomanian through Santonian (100-84 Ma) stage of tectonic model. See text for explanation of tectonic events and figure 7 for explanation of abbreviations, symbols, and patterns. 
arc overlapped the previously accreted Kolyma-Omolon superterrane, part of the North Asian cratonal margin (NSV), and adjacent terranes in the present-day Russian Northeast and western Alaska and extended for about $3,500 \mathrm{~km}$ along an active continental margin. Associated with the arc was oblique subduction of part of the ancestral Pacific oceanic plate to form the West Kamchatka (WK), Ekonay (EK), and Yanranay (YN) terranes.

5. In the Arctic Ocean, sea-floor spreading and associated rifting continued (Grantz and others, 1990, 1991, 1998; Lawver and Scotese, 1990) with the formation of new oceanic crust and the combined Alpha and Mendeleev Ridges (am) that are interpreted as large piles of hotspot basalt and associated deposits (Grantz and others, 1990, 1991, 1998). The large Amerasia (ab), Canada (cb) and Eurasia (eb) Basins continued to form. During the opening of these basins, North American continental-margin terranes, including the Arctic Alaska superterrane (AA) and the Chukotka terrane $(\mathrm{CH})$, and outboard oceanic and island terranes migrated toward the North Asian Craton and the previously accreted Kolyma-Omolon superterrane (KLO). The opening of the basins is interpreted as causing oroclinal warping of northern Alaska and the northern part of the Russian Far East.

6. Also during the opening of the Amerasia (ab), Canada (cb), and Eurasia (eb) Basins, the South Anyui and Angayucham Oceans were closed, and the Chukotka $(\mathrm{CH})$ and Arctic Alaska terranes (AA) accreted to Northeast Asia. During closure, the major Nutesyn and Koyukuk island arcs and companion subduction zones were thrust onto the Chukotka continental-margin terrane $(\mathrm{CH})$ and the Arctic Alaska superterrane (AA) in thrust sheets that are as much as $150 \mathrm{~km}$ wide in northern Alaska. The overthrust subduction-zone terranes include the South Anyui (SA), Velmay (VE), Angayucham (AG), and Goodnews (GD) terranes; the overthrust island-arc terranes include the Nutesyn (NU), Koyukuk (KY), and Togiak (TG) terranes. A final stage of blueschist-facies metamorphism of oceanic and continental-margin terranes occurred during thrusting. The absence of evidence of a huge Himalayan-type mountain range in the Russian Northeast suggests either that (1) strike-slip translation was more dominant than rifting in formation of the Canada Basin (Lane, 1994, 1997) or that (2) a major part of the rift migration of the Russian Northeast away from the Canada Basin was absorbed in the subduction zone associated with formation of the Okhotsk-Chukotka arc.

7. During accretion, the southern margin of the eastern Chukotka terrane $(\mathrm{CH})$, the southern part of the Arctic Alaska superterrane (AA), and the outboard Seward (SD), Coldfoot (CO), Goodnews (GD), and Ruby (RB) terranes continued to be intensely deformed and metamorphosed. At the end of accretion, a period of extensional deformation occurred along the southern margin of the Arctic Alaska superterrane (AA) (Miller and Hudson, 1991).

8. Backarc continental-margin sedimentation in the Kus- kokwim Basin (kw) occurred in a dextral wrench-fault setting (Bundtzen and Miller, 1997).

9. The final stage of accretion of the Wrangellia superterrane (WRA) was completed at about $95 \mathrm{Ma}$ (northern-accretionary interpretation). Several major geologic events are interpreted as having been caused by accretion of the Wrangellia superterrane. (1) The extensive Gravina island arc, which formed along the leading edge of the superterrane, and the Spences Bridge volcanicplutonic belt ( $\mathrm{sb}$ ) ceased activity after accretion. (2) The Kahiltna (kh) and Gravina-Nutzotin-Gambier (gg) assemblages were thrust under the North American continental margin (Stanley and others, 1990; McClelland and others, 1991, 1992a, b; Nokleberg and others, 1994a) and were intensely deformed during a major period of orthogonal convergence that replaced the previous sinistral convergence. (3) The northeasternmost boundary of the accreted Wrangellia superterrane became the locus of Late Cretaceous high-grade metamorphism, plutonism, contractional deformation, crustal thickening, uplift, and erosion that characterize the present-day Coast Mountains of the Canadian Cordillera and southeastern and south-central Alaska (McClelland and others, 1991, 1992a, b; Pavlis and others, 1993; Plafker and Berg, 1994; Monger and Nokleberg, 1996). (4) A regional core complex formed in the previously accreted Yukon-Tanana terrane (part of the collage in present-day Alaska) and developed a subhorizontal fabric, imbricate thrusting of large subhorizontal nappes, and subsequent extension and removal of as much as $10 \mathrm{~km}$ of crust (Pavlis and others, 1993). (5) The southern part of the Gravina arc and companion subduction zone was doubled during the latest stage of sinistral-slip faulting during accretion of the Wrangellia superterrane (McClelland and others, 1991, 1992a, b; Monger and others, 1994; Monger and Nokleberg, 1996). The Methow turbidite-basin terrane (MT), an Early Cretaceous and mid-Cretaceous forearc part of the Gravina arc, and the companion Bridge River (BR) and Easton (EA) subduction-zone terranes were structurally imbricated behind the southern part of the Gravina-Nutzotin-Gambier assemblage (gg) (Monger and others, 1994). (6) The mainly orthogonal convergence and accretion of the Wrangellia superterrane initiated eastward thrusting of the North American cratonal margin (NAM) over the North American Craton (NAC). (7) Coeval with thrusting and occurring along the axis of thrusting was intrusion of the Omineca-Selwyn granitic belt (om) that occurs along the length of present-day Canadian Cordillera, Alaska, and the northern part of the Russian Northeast. This belt was generated during an intense period of anatectic melting, major regional thrusting, and crustal shortening and thickening, all related to orthogonal convergence. Alternatively, the Wrangellia superterrane accreted far to the south at about $35^{\circ}$ paleolatitude along the margin of Baja British Columbia (latitude of present-day Baja California) (southern-accretion interpretation; see inset, fig. 16). 


\section{Summary of Paleolatitude Data for the Cenomanian Through Santonian}

For the Russian Far East, supporting paleolatitude data (table 3 ) are (1) three values ranging from about $28^{\circ}$ to $37^{\circ}$ (grades A, B) for the Nemuro terrane, (2) $42^{\circ}$ (grade A) for the Vetlovskiy terrane, (3) $76^{\circ}$ (grade C) for the Omolon terrane, (4) $76^{\circ}$ (grade A) for Cretaceous rocks overlapping the Ekonay terrane, and (5) $88^{\circ}$ (grade C) for a locality in the Okhotsk-Chukotka volcanic-plutonic belt overlying the Viliga terrane. Other paleolatitudes of $22^{\circ}$ and $24^{\circ}$ (grade A) for Late Triassic through Early Cretaceous rocks of the Ekonay terrane probably represent ages of the oceanic lithosphere that constitutes this accretionary-wedge complex.

For Alaska and the Canadian Cordillera, paleolatitude data (table 3) supporting the northern-accretion interpretation for the Wrangellia superterrane are $60^{\circ}$ (grade C) for the Skelly Creek batholith and Summit stock in the Coast-North Cascade plutonic belt. Paleolatitude data supporting the southern-accretion interpretation for the Wrangellia superterrane (table 3) are (1) $25^{\circ}$ (grade B) for the Chignik/Hoodoo units in the Peninsular sequence of the Wrangellia superterrane, (2) $32^{\circ}$ (grade B) for the MacColl Ridge Formation in the Wrangellia sequence of the Wrangellia superterrane in southern Alaska, (3) $37^{\circ}$ (grade A) for the Methow terrane in the southern part of the Canadian Cordillera, and (4) $38^{\circ}$ (grade B) for the Silverquick and Powell Creek units in the Tyaughton Basin in the Stikinia terrane of the central part of the Canadian Cordillera. Paleolatitude data supporting an intermediate locus for accretion of the Wrangellia superterrane are $46^{\circ}$ and $53^{\circ}$ (grade A) for localities in the Spences Bridge volcanic-plutonic belt in the southern part of the Canadian Cordillera.

\section{Campanian Through Early Eocene (84-52 Ma)}

During the Campanian though Early Eocene (84-52 Ma), the major tectonic events were (1) continuation of a series of continental-margin arcs and companion subduction-zone assemblages around the Circum-North Pacific (table 2); (2) completion of opening of the Amerasia, Canada, and Eurasia Basins; (3) completion of accretion of the Wrangellia superterrane; (4) a change to dextral transpression in the eastern part of the Circum-North Pacific between the Kula oceanic plate and the North American continental margin; (5) oblique subduction of the Kula-Farallon oceanic ridge under the margins of southern and southeastern Alaska; and (6) northward migration of previously accreted terranes along the margin of the North American Cordillera.

\section{Specific Tectonic Events for the Campanian Through Early Eocene}

1. Far to the south, at about $50^{\circ}-60^{\circ}$ paleolatitude (table 3 ), the extensive Olyutorka island arc continued to form. Parts of this arc are preserved in the Nemuro (NE), Kronotskiy (KRO), Olyutorka-Kamchatka (OKA), and Iruneisky (IR) island-arc terranes. Associated with the arc was subduction of part of the adjacent oceanic plate to form the Vetlovskiy terrane (VT). This arc and companion subduction zone migrated northward toward the OkhotskChukotka continental-margin arc. In the early Eocene, at about $50 \mathrm{Ma}$ (Heiphitz and others, 1994a; Brandon and others, 1997), the Olyutorka island arc accreted against the West Kamchatka accretionary-wedge terrane (WK) along the Vatyn thrust of Brandon and others (1997, 1998), which is interpreted as a low-angle, seawarddipping zone of obduction (Brandon and others, 1997; Ramthun and others, 1997). Accretion is interpreted as occurring during the Eocene (Brandon and others, 1998; Garver and others, 1998; Solo'ev and others, 1998; Konstantinovskaya, 1999). Alternatively, Geist and others (1994) inferred that the Olyutorka arc and its companion subduction zone formed near the margin of present-day Northeast Asia.

2. Farther west, the East Sikhote-Alin continental-margin arc (es) and related deposits continued activity. Forming as part of this arc was the West Sakhalin (WSA) turbiditebasin terrane. Associated with the arc was oblique subduction of part of the Pacific oceanic plate (PAC) to form the Hikada (HI), Aniva (ANV), and Nabilsky (NAB) terranes (table 2).

3. The Okhotsk-Chukotka continental-margin arc continued activity. Parts of this arc are preserved in the OkhotskChukotka volcanic-plutonic belt (oc) and related Penzhina (forearc) sedimentary basin (pn). Associated with the arc was subduction of part of the Pacific oceanic plate (PAC) to form the West Kamchatka (WK) and Ekonay (EK) terranes (table 2). Local plutons in the Okhotsk-Chukotka volcanic-plutonic belt intruded under extension, probably as the result of rollback of the subduction slab during the Late Cretaceous (Amato and Wright, 1997). Also in the same region, the Okhotsk-Chukotka and East SikhoteAlin continental-margin arcs were offset in a sinistral sense along the Mongol-Okhotsk Fault System (MO).

4. Between the areas of the present-day Russian Far East and Alaska, continental-margin arcs and companion subduction zones in each region were connected by a major transform fault. In the area of present-day western Alaska, tectonic escape (crustal extrusion) of terranes occurred along major dextral-slip faults, including the Denali (DE), Nixon Fork (NF), Kaltag (KA), and companion faults (Scholl and others, 1992, 1994). In association with movement on these major dextral-slip faults, dextral-wrench sedimentary basins formed, including the Kuskokwim Basin (kw) (Plafker and Berg, 1994; Bundtzen and Miller, 1997). The crustal extension and wrench faulting were associated with a major period of extension in interior Alaska, according to the interpretation of Miller and Hudson (1991). The mid-Cretaceous and Late Cretaceous extension is interpreted as having formed warm, thin continental crust that was favorable for crustal extrusion and dextral-wrench faulting (Scholl and others, 1992, 1994).

5. By the early Tertiary, in the region of the Amerasia (ab), Canada (cb), and Eurasia (eb) Basins, sea-floor spreading and associated rifting was completed (Grantz and others, 
1990, 1991, 1998), and sedimentation continued in these large basins. The formation of the Alpha and Mendeleev Ridges (am), which are interpreted as large piles of hotspot basalt and associated deposits, was completed (Grantz and others, 1990, 1991, 1998).

6. During the Paleocene (approx 60-56 Ma), in the area of the present-day Bering Sea, major counterclockwise rotation (oroclinal bending) of the Pacific oceanic plate (PAC) occurred (at about $30^{\circ}-50^{\circ}$ paleolatitude) (Lonsdale, 1988). This rotation resulted from compression between Eurasia and North America (Plafker and Berg, 1994). At the same time, the extension of dextral-slip faults from the area of present-day western Alaska into the Bering Sea resulted in capture and accretion of a fragment of the Kula oceanic plate (KULA) (Scholl and others, 1992, 1994).

7. In response to oblique subduction of the Kula oceanic plate (KULA), the major Kluane continental-margin arc formed (Bradley and others, 1993). Parts of this arc are preserved as the Kuskokwim Mountains volcanic-plutonic belt (km) and the Alaska Range-Talkeetna Mountains igneous belt (at). The coeval Coast arc formed along the margin of the North American Cordillera. Parts of this arc are preserved in the Coast-North Cascade plutonic belt ( $\mathrm{cn}$ ) and the Kamloops magmatic belt (kl). These continental-margin arcs overlapped the previously accreted
Wrangellia superterrane and adjacent inboard terranes and extended for a distance of more than $3,200 \mathrm{~km}$ along the active continental margin of the North American Cordillera. Associated with these continental-margin arcs was subduction of the laterally extensive Chugach terrane (CG) and the Pacific Rim terrane (PAR) (table 2).

8. Along the active margin of the North American Cordillera, rapid northward migration of the Kula oceanic plate (KULA), which started to form at about $85 \mathrm{Ma}$ (Englebretson and others, 1985), resulted in the formation of major dextral-slip faults, including the Denali (DE), Tintina (TI), Ross Lake (RL), and companion faults (Plafker and Berg, 1994). Oblique subduction of the KulaFarallon oceanic ridge occurred at about 60 to $50 \mathrm{Ma}$ along the margin of southern Alaska (Bradley and others, 1993). Subduction of the oceanic ridge, locally partly preserved in ophiolites in the Prince William terrane (Lytwyn and others, 1997; Kusky and Young, in press), during the early Tertiary is interpreted as causing (1) a regional metamorphic welt and the formation of anatectic granites (Plafker and others, 1989b, 1994), (2) rapid changes in the components of strike-slip movement along the subduction zone bordering the early Tertiary continental margin (Bradley and others, 1993), and (3) formation of belts of early Tertiary granitic and mafic-ultramafic plutonic rocks of the Sanak-Baranof plutonic belt (sab) (Hudson,

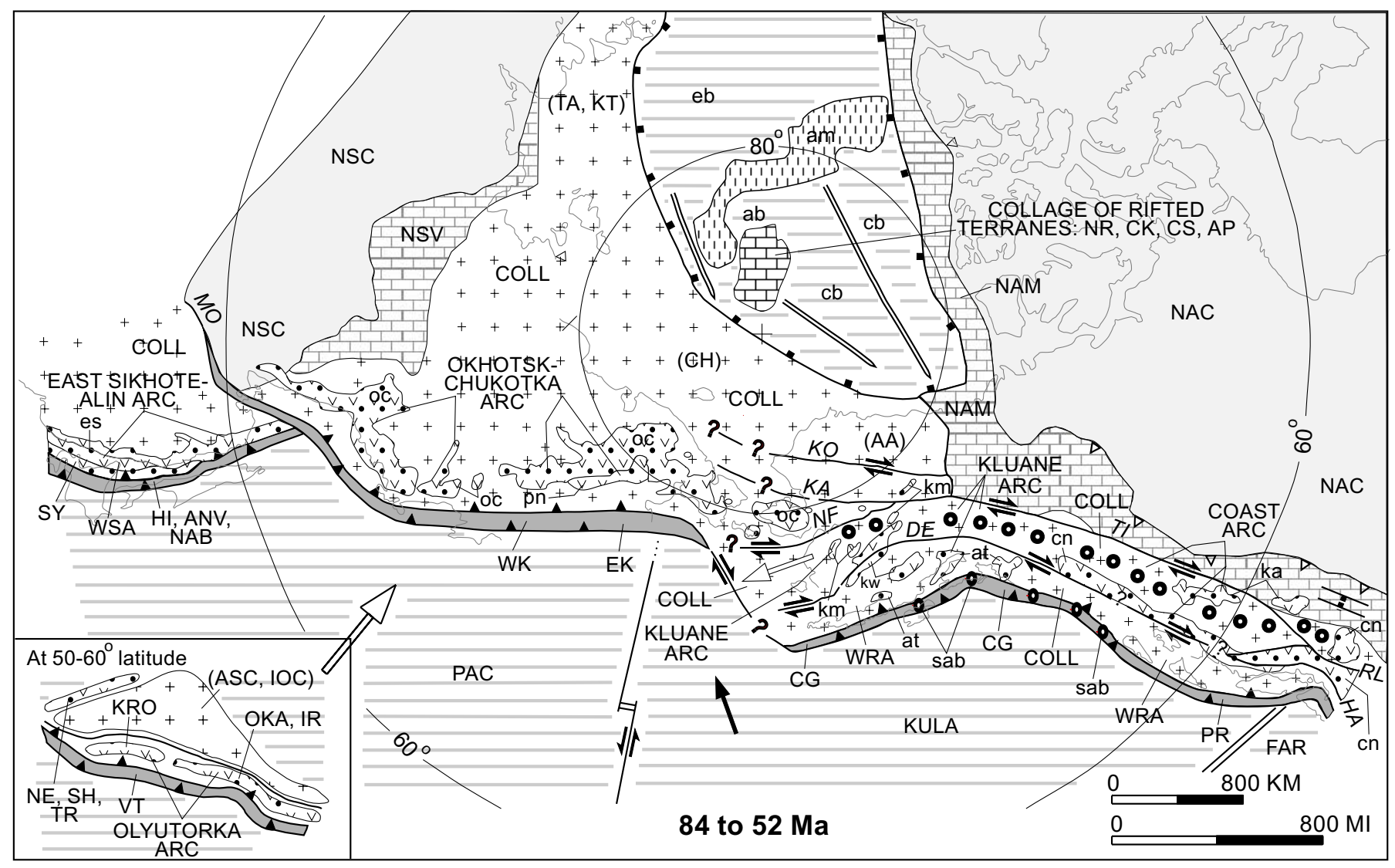

Figure 17.-Campanian through early Eocene (84-52 ma) stage of tectonic model. See text for explanation of tectonic events and figure 7 for explanation of abbreviations, symbols, and patterns. 
1979; Moll-Stalcup and others, 1994) in southern and southeastern Alaska that are interpreted as having formed in a near-trench environment during subduction of the Kula-Farallon oceanic ridge (Bradley and others, 1993; Kusky and others, 1997).

9. Regional extension occurred in the present-day southern part of the Canadian Cordillera and northeastern Washington. This extension is interpreted either as (1) the result of a change from transpression to transtension at about 55 Ma (Parrish and others, 1988); (2) caused by a change in the obliquity of convergence of the oceanic plate; or (3) alternatively, but likely, collapse of overthickened thrust units.

10. The eastward thrusting of the North American cratonal margin (NAM) over the North American Craton (NAC) ended at about $60 \mathrm{Ma}$ in the present-day Canadian Cordillera.

11. For the southern-accretion interpretation for the Wrangellia superterrane, rapid northward transport of the superterrane commenced (not shown in fig. 17; Irving and others, 1996; Cowan and others, 1997) along unknown dextralslip faults (Monger and others, 1996). The total amount of Late Cretaceous and early Tertiary northward translation is under debate (Monger, 1993; Cowan, 1994). Some paleomagnetic studies suggest that, for this interval, the inner parts of the present-day Canadian Cordillera, west of the Tintina (TI) and Northern Rocky Mountain Trench (NR) Faults (fig. 4), were displaced northward about 1,200 to $1,400 \mathrm{~km}$, whereas early Late Cretaceous plutons and stratified rocks in the present-day Coast Mountains of Canada were displaced about 3,500 km (Irving and others, 1996). However, displacements based on offsets of geologic units across faults are much smaller (see discussion in Monger and Nokleberg, 1996). Resolution of this problem is clearly of major importance.

\section{Summary of Paleolatitude Data for the Campanian Through Early Eocene}

For the Russian Far East, supporting paleolatitudes (table 3 ) include $49^{\circ}-60^{\circ}$ (grades A-C) for four localities in the Olyutorka-Kamchatka terrane (Koryakia sedimentary rocks, Machevna Bay, Apuka River, Olytorskii Ridge, and Koryak Highlands). Conflicting paleolatitudes (table 3) are (1) $37^{\circ}-43^{\circ}$ (grade C) for three localities in the West Sakhalin terrane, (2) $32^{\circ}$ and $81^{\circ}$ (grades B, C) for two localities in the Olyutorka-Kamchatka terrane (Javevyn Bay and Tavlovka River, respectively), (3) $25^{\circ}$ (grade A) for the Kronotskiy terrane, (4) about $39^{\circ}$ (grade A) for the Kamchatskiy Mys terrane that occurs at the west edge of the incipient Aleutian-Wrangell arc (fig. 18), and (5) about $43^{\circ}$ (grade A) for unnamed sedimentary rocks in the Aleutian volcanic belt in the Komandorski Islands (Medny Island).

For Alaska and the Canadian Cordillera, supporting paleolatitude data (table 3) are (1) $57^{\circ}-78^{\circ}$ (grades A, C) for various volcanic-rock units in the Interior Alaska volcanic belt (Unalakleet quadrangle, Yukon-Koyukuk Basin, Yukon-
Tanana Upland); (2) about $70^{\circ}-80^{\circ}$ (grade A) for overlap volcanic rocks in southern Alaska, including two localities in the Talkeetna Volcanics, two localities in the Alaskan RangeTalkeetna Mountains volcanic-plutonic belt, and two localities in the Cantwell Formation; and (3) $67^{\circ}$ (grade A) for the Masset Formation overlying the southern part of the Wrangellia superterrane. The values for the overlap volcanic rocks and the Masset Formation support the northern-accretion interpretation for the Wrangellia superterrane.

For Alaska and the Canadian Cordillera, paleolatitude data (table 3) supporting the southern-accretion interpretation for the Wrangellia superterrane are (1) $54^{\circ}$ (grade A) for the Chickaloon Formation overlying the Peninsular sequence of the northern part of the Wrangellia superterrane on the Alaska Peninsula; (2) 55 (grade A) for the Arkose Ridge Formation overlying the Peninsular sequence of the northern part of the Wrangellia superterrane in southern Alaska; (3) $43^{\circ}$ (grade C) for the Butedale pluton in the Coast-North Cascade plutonic belt; (4) about $53^{\circ}-57^{\circ}$ (grades A, C) for igneous and sedimentary rocks intruding or overlying various parts of the central and southern parts of the Wrangellia terrane (AX and WR sequences) (Point Camden gabbro, Flores Volcanics in the Cascade volcanic-plutonic belt, Carmacks volcanic field, and Coast-North Cascade plutonic belt [Kelowna Volcanics]); (5) $46^{\circ}$ (grade C) for the East Sooke gabbro, part of the Cascade volcanic-plutonic belt overlying the southern part of the Wrangellia superterrane; and (6) $59^{\circ}$ (grade A) for the Kamloops volcanic belt in the southern part of the Canadian Cordillera.

For Alaska, conflicting paleolatitudes (table 3) are (1) $62^{\circ}$ (grade A) for unnamed flows overlying the Kahiltna sedimentary and volcanic assemblage in the Lake Clarke quadrangle, southern Alaska; (2) $0^{\circ}$ (grade A) for a locality in the Interior Alaska volcanic belt in the Yukon-Koyukuk Basin; (3) $64^{\circ}$ and $67^{\circ}$ (grades A, B) for the Kuskokwim Mountains belt in the Bering Sea region; and (4) $8^{\circ}$ (Grade B) for the Brothers Volcanics overlying the Gravina-Nutzotin-Gambier overlap assemblage in southern Alaska.

\section{Middle Eocene Through Early Miocene (42-23 Ma)}

During the middle Eocene to early Miocene (42-23 Ma), the major tectonic events were (1) continuation of a series of continental-margin arcs and companion subduction-zone assemblages around the Circum-North Pacific (table 2), (2) continuation of sea-floor spreading in the present-day Arctic and eastern Pacific Oceans, (3) establishment of a new continental margin in the northern and eastern parts of the Circum-North Pacific as the result of disappearance of the Kula oceanic plate and inception of subduction of the leading edge of the Pacific oceanic plate, (4) continuation of dextral transpression between the Pacific oceanic plate (PAC) and the North American continental margin in the eastern part of the Circum-North Pacific, and (5) a change to orthogonal transpression between the Pacific oceanic plate and the southern Alaska continental margin because of counterclockwise rotation of western Alaska. 
At about $50 \mathrm{Ma}$ (Vogt and others, 1979), the Gakkel Ridge (GK) (northward extension of the Mid-Atlantic Ridge) was initiated, and sea-floor spreading extended into the Eurasia Basin (eb) in the Arctic Ocean, thereby resulting in the North American-Eurasia plate boundary in the Russian Northeast. The exact position of the Euler pole changed throughout the Cenozoic, thereby resulting in regional changes in the stress regime (Savostin and others, 1984; Harbert and others, 1990). Analysis of marine magnetic anomalies in the Eurasia Basin suggests that the region underwent extension from about 56 to $36 \mathrm{Ma}$ (Savostin and Drachev, 1988a, b; Harbert and others, 1990; Fujita and others, 1997).

\section{Specific Tectonic Events for the Middle Eocene Through Early Miocene}

1. The younger, bimodal volcanic and plutonic rocks of the youngest part of the East Sikhote-Alin volcanic-plutonic belt (es), mainly basalt, rhyolite, and associated granitic plutonic rocks, are herein interpreted as having formed in a dextral-transpression tectonic regime.

2. In the present-day central and southern parts of the Russian Far East, tectonic wedging occurred because of accretion of the India plate against the Eurasia plate (Worall and others, 1996). This tectonic wedging resulted in sinistral displacement along the reactivated Mongol-Okhotsk Fault (MO) and dextral displacement along the SakhalinHokkaido Fault ( $\mathrm{SH}$ ) parallel to the margin of the presentday Russian Far East. A complex array of normal faults, echelon folds, and thrusts is interpreted as having formed within and adjacent to the tectonic wedge (Worall and others, 1996). The relation between sinistral movement along the reactivated Mongol-Okhotsk Fault and dextral movement along the Denali (DE), Tintina (TI), and related faults to the east in present-day mainland Alaska is unclear.

3. The bimodal volcanic and plutonic rocks of the Kamchatka-Koryak volcanic-plutonic belt (kk) are herein interpreted as having formed in a sinistral tectonic regime.

4. Rifting commenced at about $50 \mathrm{Ma}$ along the Gakkel Ridge (GK) (northward extension of the Mid-Atlantic Ridge) and extended into the present-day Russian Northeast (Fujita and others, 1997). This rifting is interpreted as causing eruption of basalts in the present-day Chersky Range at about $37 \mathrm{Ma}$ (Fujita and others, 1997). The Lomonosov Ridge terrane (LO) is interpreted as having formed during the rifting of passive-continental-margin units now preserved in the Barents Sea region (outside area of fig. 18; Zonenshain and others, 1990). Sedimenta-

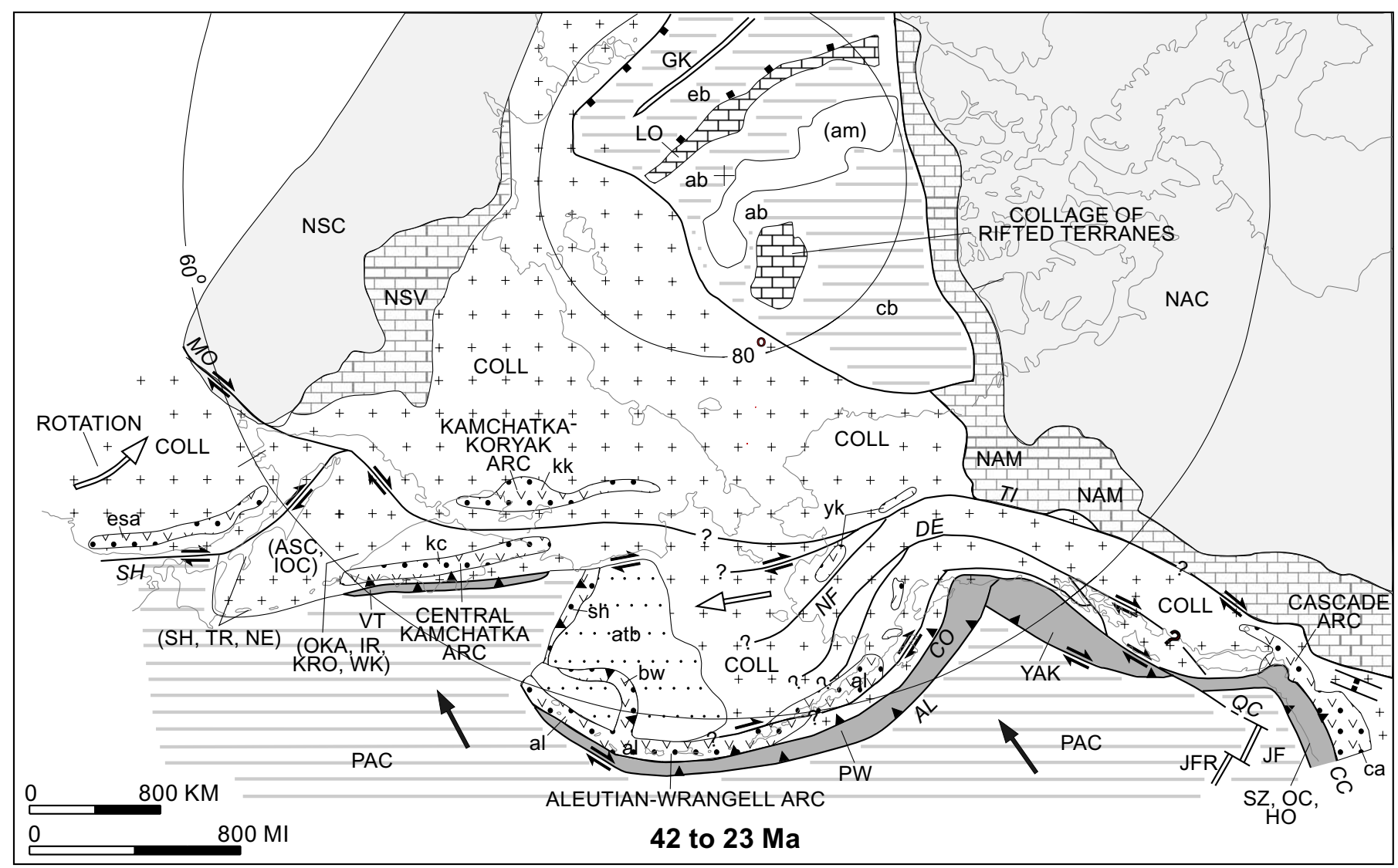

Figure 18.-Middle Eocene through early Miocene (42-23 Ma) stage of tectonic model. See text for explanation of tectonic events and figure 7 for explanation of abbreviations, symbols, and patterns. 
tion continued in the large Amerasia (ab), Canada (cb), and Eurasia (eb) Basins.

5. A short-lived period of marine arc volcanism formed the Bowers (bw) and Shirshov (sh) Ridges in the Bering Sea. The arc formed on the rear edge of the previously accreted Aleutia terrane (al), a fragment of the Kula oceanic plate (Scholl and others, 1992, 1994) The Bowers Ridge volcanic belt consists chiefly of intermediate-composition volcanic rocks, mainly altered andesite, breccia, volcaniclastic sedimentary rocks, and lesser diatomaceous siltstone (Cooper and others, 1992; Scholl and others, 1992). Analysis of sparse dredge samples and Deep Sea Drilling Project drill cores suggests a Miocene age for the volcanic rocks. The presence of a trench filled with as much as 12 $\mathrm{km}$ of sedimentary rocks at the base of the north and east slopes of the Bowers Ridge suggests that the unit formed in an early Tertiary arc-trench system that faced northeast. The Shirshov Ridge volcanic belt consists chiefly of two assemblages; (1) a relatively older oceanic assemblage composed of amphibolite, gabbro, diabase, basalt, and chert, in which the chert contains Late Cretaceous (Campanian to Maastrichtian) to early Paleogene microfauna; and (2) a relatively younger volcanic-arc assemblage composed of altered andesite, volcaniclastic sedimentary rocks, and shale of Miocene and younger age (Baranov and others, 1991; Scholl and others, 1992). Alternatively, the Bowers and Shirshov Ridges may be the northward extension of the Olyutorka-Kamchatka island arc (OKA) (Brandon and others, 1997). Also in the Bering Sea, a thick sedimentary prism started to form in the AleutianBowers sedimentary basin (atb) that overlies the Aleutia terrane (Scholl and others, 1992, 1994; Plafker and Berg, 1994).

6. Tectonic escape (crustal extrusion) of terranes continued to occur along major dextral-slip faults, including the Denali (DE), Nixon Fork (NF), Kaltag (KA), and companion faults in the area of present-day western Alaska and the Bering Sea (Scholl and others, 1992, 1994). Dextral-wrench basins continued to form in association with these major dextral-slip faults and were rapidly filled with continental sedimentary materials. Coincident with crustal extrusion was counterclockwise oroclinal bending of present-day Alaska that may have resulted from compression between Eurasia and North America (Scholl and others, 1992, 1994; Plafker and Berg, 1994). To the east, in the area of present-day southern Alaska, displacement continued along major dextral-slip faults, including the Denali, Nixon Fork, and Kaltag Faults. These and similar dextral-slip faults probably extended into the area of the present-day Bering Sea.

7. The Pacific oceanic plate (PAC) moved toward North America as a result of sea-floor spreading along the Juan de Fuca oceanic ridge. Along the Aleutian megathrust (AL), plate convergence continued to range from oblique-orthogonal in the east to oblique in the west. Oblique-transpressive displacement occurred between the Pacific oceanic plate and the southern part of the Canadian Cordillera.
8. As a result of accretion of part of the Kula oceanic plate (underlying the Aleutian-Bowers sedimentary basin), and stepout of subduction, the western part of Aleutian-Wrangell arc (al) was initiated at about $40 \mathrm{Ma}$. This major Andean-type arc overlapped the previously accreted Kula oceanic plate and initially extended for a distance of about $3,000 \mathrm{~km}$ along the Bering Strait and southern Alaska. Associated with the arc was subduction of part of the Pacific oceanic plate (PAC) to form the Prince William (PW) and Yakutat (YA) terranes along the Aleutian megathrust (AL).

9. At about 30 to $25 \mathrm{Ma}$, a major tectonic change occurred in the southern part of the Canadian Cordillera with tectonic overriding of the northern segment of the Juan de Fuca oceanic ridge (JFR) and resulting establishment of dextral slip along the Queen Charlotte Fault (QC). This tectonic change ended subduction of the Farallon oceanic plate (FAR) and started northward migration and subduction of the Yakutat terrane (YAK), resulting in the beginning of volcanism in the Wrangellia volcanic field (wr) in the eastern part of the Aleutian-Wrangell arc. Total movement of the Yakutat terrane is estimated at about $600 \mathrm{~km}$ (Plafker and Berg, 1994; Plafker and others, 1994). Movement ceased along major dextral-slip faults in the interior part of the Canadian Cordillera, including the Tintina (TI) and Fraser Creek-Straight Creek (FS) Faults. Between lat $51^{\circ}$ and $60^{\circ} \mathrm{N}$., the Queen Charlotte transform fault separated the Cascade arc and the Aleutian-Wrangell arc. This fault forms the present-day North American plate margin between Vancouver Island, Canada, and the northern part of southeastern Alaska.

10. Offshore of the southern part of the Canadian Cordillera, sea-floor spreading occurred along the Juan de Fuca oceanic ridge (JFR). To the east, subduction of the Juan de Fuca plate (JF) resulted in initiation of the Cascade continental-margin arc (ca). Part of the subducting plate is preserved in the Siletzia (SZ), Olympic Core (OC), and Hoh $(\mathrm{HO})$ terranes along branches of the Cascadia megathrust (CC).

11. For the southern-accretion interpretation for the Wrangellia superterrane, rapid northward transport of the superterrane (not shown in fig. 18) was completed (Irving and others, 1996; Cowan and others, 1997) along unknown dextral-slip faults (Monger and others, 1996).

\section{Summary of Paleolatitude Data for the Middle Eocene Through Early Miocene}

For the Russian Far East, supporting paleolatitude data (table 3) include $65^{\circ}$ (grade A) for the Central Kamchatka volcanic belt. Conflicting paleolatitudes (table 3) are (1) $40^{\circ}-47^{\circ}$ (grades A, D) for the East Kamchatka volcanic belt; and (2) $51^{\circ}-54^{\circ}$ (grade A) for the Central Kamchatka volcanic belt, Karaginskii Island, and the Ilpinskii Peninsula.

For Alaska and the Canadian Cordillera, supporting paleolatitude data (table 3 ) are (1) $57^{\circ}$ (grade A) for sedimentary rocks on Umnak Island, near the Aleutian Islands, (2) $74^{\circ}$ 
(grade D) for a locality in the Interior Alaska volcanic belt in the Yukon-Koyukuk Basin, (3) about $51^{\circ}$ (grade C) for the Hope pluton in the Cascade volcanic-plutonic belt, and (4) $59^{\circ}$ (grade A) for the Resurrection Peninsula ophiolite at the base of the Prince William terrane in southern Alaska. For Alaska and the Canadian Cordillera, paleolatitude data (table 3) supporting a southerly origin for the Prince William terrane (not shown in fig. 18) are $34^{\circ}-47^{\circ}$ (grades A, B) for four localities in the Prince William terrane in south-central Alaska (Kiluda Bay, Alitak Bay, Knight Island, Glacier Island). For Alaska and the Canadian Cordillera, conflicting paleolatitudes (table 3) are (1) 69 (grade A) for unnamed sedimentary rocks on Amlia Island, part of the Aleutian-Bowers sedimentary basin; and (2) $65^{\circ}$ (grade C) for the Quotton pluton in the Coast-North Cascade plutonic belt.

\section{Miocene (20-10 Ma)}

During the Miocene (20-10 Ma), the major tectonic events were (1) continuation of a series of continental-margin arcs and companion subduction-zone assemblages around the CircumNorth Pacific (table 2); (2) backarc spreading behind the major arcs; (3) opening of major sedimentary basins behind major arcs; (4) in the eastern part of the Circum-North Pacific, a continuation of dextral transpression between the Pacific oceanic plate and the Canadian Cordillera margin and a continuation of orthogonal transpression between the Pacific plate and the southern Alaska continental margin; and (5) continued seafloor spreading in the Arctic and eastern Pacific Oceans.

\section{Specific Tectonic Events for the Miocene}

1. After the accretion of various terranes during the early Eocene, the Northeast Asia arc commenced activity. Parts of this arc are preserved in the East Japan volcanic-plutonic belt (ej), the Kuril volcanic arc (ku), and the various parts of the Kamchatka arc consisting of the Central Kamchatka volcanic belt (kc), the Central Kamchatka volcanic and sedimentary basin (ck), and the West Kamchatka sedimentary basin (wk). To the northeast, the Okhotsk-Chukotka arc completed activity. These two major Andean-type arcs overlapped previously accreted adjacent terranes in both the Russian Southeast and to the south and extended for a distance of about 3,000 $\mathrm{km}$. Associated with these arcs was subduction of part of the Pacific oceanic plate (PAC) along the Kuril-Kamchatka megathrust (KK) to form the Kuril-Kamchatka subduction-zone terrane (KUK) (table 2). Intra-arc faulting resulted in tectonic doubling of the KamchatkaKoryak (kk) arc, which started to become extinct as the Central Kamchatka arc (kc) enlarged.

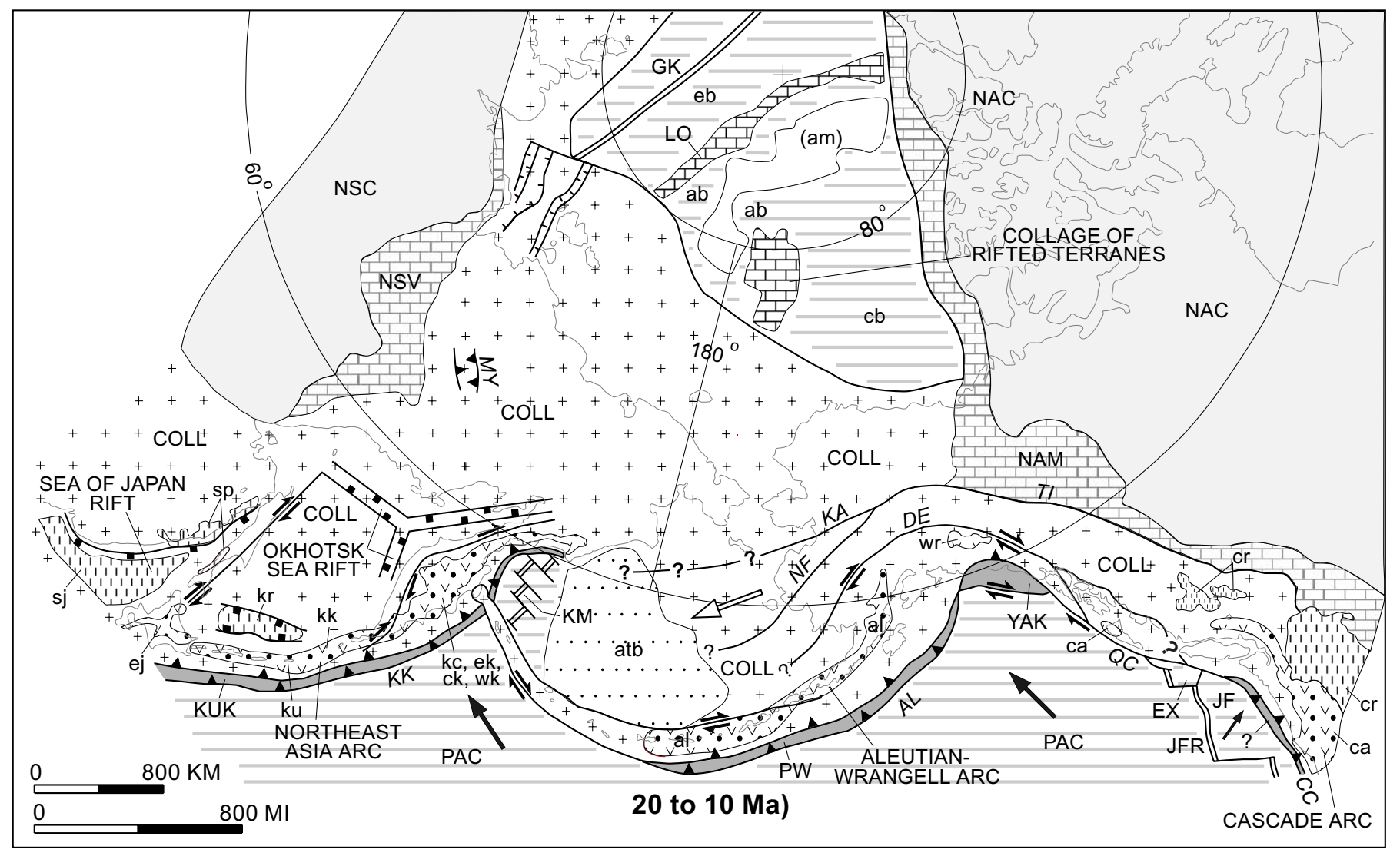

Figure 19.-Miocene (20-10 Ma) stage of tectonic model. See text for explanation of tectonic events and figure 7 for explanation of abbreviations, symbols, and patterns. 
2. Regional extension associated with backarc spreading behind the northern Japan part of the Northeast Asia arc (East Japan volcanic-plutonic belt, ej) resulted in marine eruption of the Sea of Japan backarc unit (sj), which consists of mainly tholeiitic basalt and associated rocks.

3. In the Sea of Okhotsk, backarc spreading occurred behind the Kuril Island and Kamchatka Peninsular part of the Northeast Asia arc (B.A. Natal'in, in Nokleberg and others, 1994a), resulting in marine and continental eruption of tholeiitic to alkalic basalt and associated rocks forming the Sakhalin-Primorye volcanic belt (sp). This regional extension is also interpreted as the result of seaward rotation of the Kamchatka Peninsula, and as resulting in the formation of major units within the Sea of Okhotsk (B.A. Natal'in, in Nokleberg and others, 1994a). Backarc spreading may have occurred simultaneously with trench rollback and migration of the Northeast Asia arc into the Pacific oceanic plate.

4. In the Arctic Ocean, rifting continued along the Gakkel Ridge (GK) along with continued sedimentation in the Amerasia Basin (as). Analysis of marine magnetic anomalies in the Eurasia Basin suggests that this region underwent compression from about 36 to $5 \mathrm{Ma}$ (Savostin and Drachev, 1988a, b; Harbert and others, 1990; Fujita and others, 1997). Geologic mapping reveals that late Miocene thrust faults and companion folds, which were associated with regional compression, occurred along the Myatisk and companion faults in the present-day Mona and Chersky Ranges, as described by Gaiduk and others (1989, 1993). Fault displacements are about 15 to $20 \mathrm{~km}$.

5. A major orthogonal junction formed between the west end of the Aleutian-Wrangell arc (al) and the Central Kamchatka arc (kc). The west terminus of the AleutianWrangell arc is interpreted as having been obducted onto the present-day Kamchatka Peninsula, thereby forming the Kamchatskiy Mys oceanic terrane (too small to show in fig. 19), which is interpreted as the oceanic base of the ancestral Aleutian-Wrangell arc, and the Stolbovskoy island-arc terrane (also too small to show in fig. 19), which is interpreted as the older, western part of the arc (Geist and others, 1988, 1994).

6. During the early to middle Miocene, a short episode (approx 22-10 Ma) of sea-floor spreading along the Komandorsky Ridge (KOM) formed a small pair of oceanic plates that exhibit magnetic anomalies 5 and 6 . This spreading occurred after the marine-arc volcanism in this area that formed the Bowers (bw) and Shirshov (sh) Ridges during the middle Eocene and early Miocene.

7. Intense tectonic disruption occurred in the western part of the Aleutian-Wrangell arc, along the western Aleutian megathrust (AL), as a result of transform coupling between the Pacific and North American plates (Geist and others, 1988). A complex array of strike-slip, extensional, and rotational structures formed in this area (Scholl and others, 1992, 1994; Vallier and others, 1994). In the area of the present-day Bering Sea, a thick sedimentary prism continued to form in the Aleutian-Bowers Basin (atb) that overlies a fragment of accreted Kula oceanic plate (Scholl and others, 1992, 1994; Plafker and Berg, 1994).

8. Tectonic escape (crustal extrusion) of terranes continued to occur along major dextral-slip faults, including the Denali (DE), Nixon Fork (NF), Kaltag (KA), and companion faults (Scholl and others, 1992, 1994). Dextralwrench basins continued to form in association with the dextral-slip faults and were rapidly filled with continental sedimentary materials.

9. The Pacific oceanic plate (PAC) continued to move northwestward. Along the Aleutian megathrust (AL), plate convergence continued to range from oblique-orthogonal in the east to oblique to transform in the west.

10. Dextral displacement continued farther east along major dextral-slip faults, such as the Denali (DF), Nixon Fork (NF), and Kaltag (KA) Faults. Estimates of total Cenozoic displacements along the Denali and Tintina Faults range from 400 to $500 \mathrm{~km}$ each (Nokleberg and others, 1985; Plafker and Berg, 1994; Monger and Nokleberg, 1996). These and companion dextral-slip faults probably extended into the area of the present-day Bering Sea.

11. The Aleutian-Wrangell continental-margin arc was associated with mainly oblique subduction of the north edge of the Pacific oceanic plate (PAC) along the Aleutian megathrust (AL) to form the Prince William terrane (PW) (table 2). During northward migration, the Yakutat terrane (YA) started to underthrust the Prince William terrane along the eastern part of the Aleutian megathrust.

12. Offshore of the southern part of the Canadian Cordillera, sea-floor spreading continued along the Juan de Fuca Oceanic ridge (JFF). Northward movement of the Pacific oceanic plate (PAC) and associated transform displacement on the Queen Charlotte transform fault (QC) resulted in continued northward migration and subduction of the Yakutat terrane (YA) beneath the continental margin of present-day southern Alaska.

13. To the south, the Cascade continental-margin arc continued activity. Associated with this arc was continued subduction of part of the Juan de Fuca plate (JF) along the ancestral Cascadia megathrust (CC). Regional extension, associated with backarc spreading behind the Cascade arc (ca), resulted in continental eruption of the Columbia River Basalt (cr) (Wells and Heller, 1988; England and Wells, 1991).

\section{Summary of Paleolatitude Data for the Miocene}

Supporting paleolatitude data (table 3) are (1) $71^{\circ}$ (grade D) for unnamed volcanic rocks overlying the Porcupine terrane in northeastern Alaska, and (2) $55^{\circ}-65^{\circ}$ (grades A, C) for three igneous-rock localities in the Cascade volcanic-plutonic belt (Mount Barr pluton, Caribou Plug, Caribou Lavas).

\section{Pliocene Through the Present (4-0 Ma)}

During the Pliocene through the present (4-0 Ma), the major tectonic events have been (1) continuation of a series of continental-margin arcs and companion subduction-zone 
assemblages around the Circum-North Pacific (table 2); (2) continuation of the opening of major sedimentary basins behind major arcs; (3) in the eastern part of the Circum-North Pacific, continuation of dextral transpression between the Pacific oceanic plate and the present-day Canadian Cordillera margin; (4) continuation of oblique-orthogonal transpression between the Pacific plate and present-day southern Alaska; and (5) continuation of sea-floor spreading in the Arctic and eastern Pacific Oceans. The modern geodynamic pattern is defined by interaction of the Eurasian, North American, and Pacific oceanic plates (Cook and others, 1987; Parfenov and others, 1989; Fujita and others, 1997). The pole of rotation between the Eurasian and North American plates is on or near the south coast of the Laptev Sea in the Russian Northeast (Cook and others, 1987; Larson and others, 1997).

\section{Specific Tectonic Events for the Pliocene Through the Present}

1. Tectonic activity of the Northeast Asia continental-margin arc is continuing. Parts of this arc are being preserved in the East Japan volcanic-plutonic belt (ej), the Kuril arc $(\mathrm{ku})$, the Central Kamchatka volcanic and sedimentary basin (kc), and the East Kamchatka volcanic belt (ek). Associated with the arc is subduction of the west edge of the Pacific oceanic plate (PAC) along the Kuril-Kam- chatka megathrust (KK) to form the Kuril-Kamchatka (KUK) terrane (table 2). A major orthogonal junction occurs between the west end of the Aleutian-Wrangell arc (al) and the Kamchatka arc (kc).

2. Rifting continues along the Gakkel Ridge (GK) (northward extension of the Mid-Atlantic Ridge) and the extension of this ridge toward the Eurasian plate. The Gakkel Ridge and its extension define the modern boundary between the North American and Eurasian plates. Analysis of sea-floor-spreading anomalies in the Eurasia Basin (eb) suggest that the Russian Northeast underwent extension from about 5 to $0.5 \mathrm{Ma}$ (Moma rift episode, as discussed by Fujita and others, 1990a, b, 1997; see Savostin and Drachev, 1988a, b; Harbert and others, 1990; Fujita and others, 1997). The youngest change, a northward pole shift, occurred at about $0.5 \mathrm{Ma}$, as indicated by resurgent or continued thrusting (Imaev, 1991). Focalmechanism studies indicate that parts of this region are undergoing compression (Cook and others, 1986; Parfenov and others, 1989; Fujita and others, 1990a, b; Riegel and others, 1993). This compression is relieved by extrusion of the Okhotsk block to the southeast (Riegel and others, 1993) and by uplift and thrusting in the CSB area (Koz'min, 1984; Imaev and others, 1990; Koz'min and others, 1996). Sedimentation continues in the Amerasia Basin (ab).

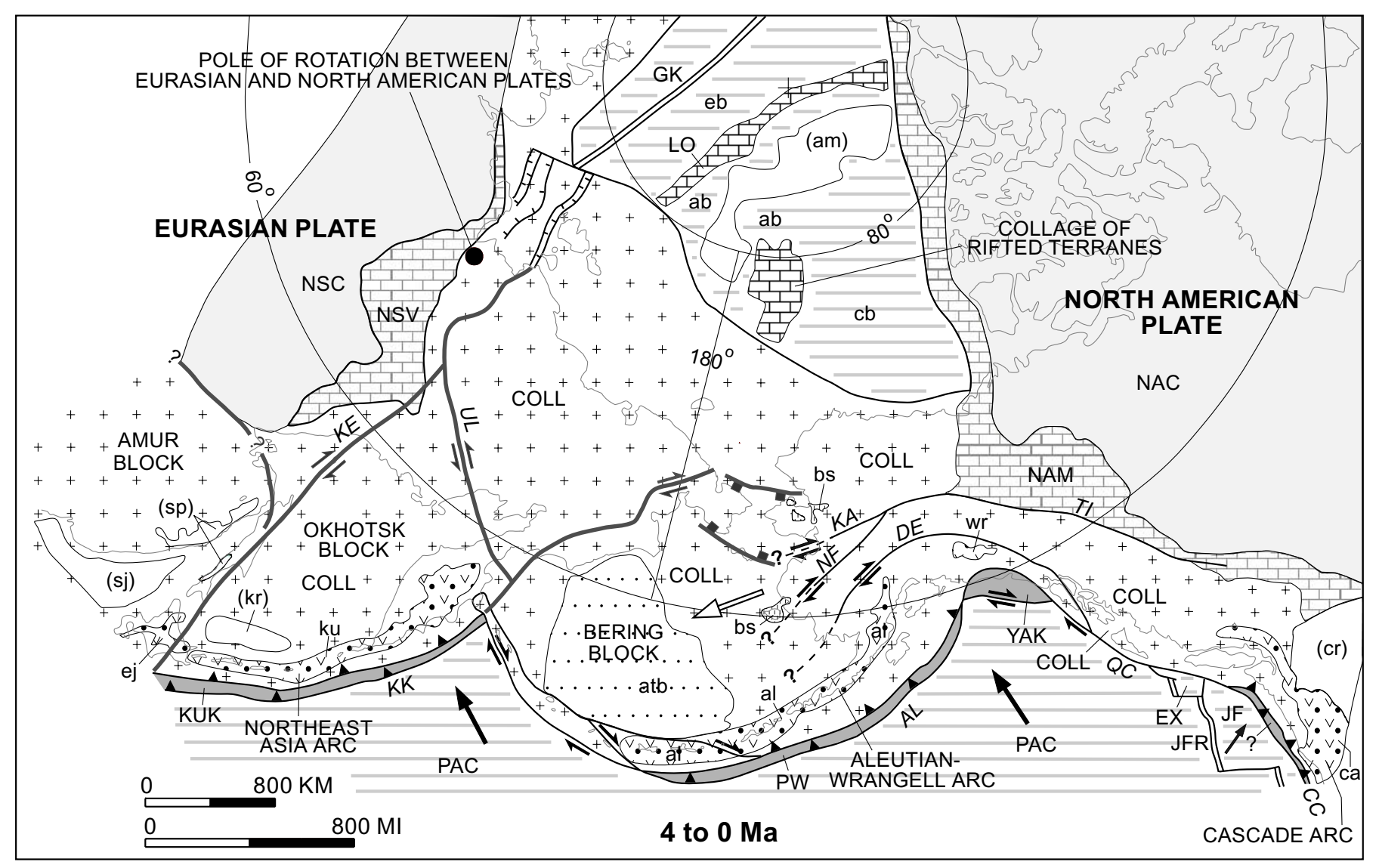

Figure 20.-Pliocene through present (4-0 Ma) stage of tectonic model. See text for explanation of tectonic events and figure 7 for explanation of abbreviations, symbols, and patterns. 
3. Present-day seismicity defines several new tectonic blocks, including the Amur, Okhotsk, and Bering blocks (Riegel and others, 1993; Fujita and others, 1997; Mackey and others, 1997). Boundaries between blocks are defined by epicenters located by teleseismic and regional networks (Fujita and others, 1997).

4. Marine and continental eruption of sparse, generally small, highly dispersed flows of Bering Strait alkaline basalt (bs) has occurred during the Quaternary. This volcanism may be related to dextral wrench faulting and tectonic escape in the region. Rotation of the Bering block caused extension on the present-day Seward Peninsula and on Chukotka (Mackey and others, 1997), or the Bering block may have formed as the backarc with respect to the Aleutian-Wrangell arc.

5. Tectonic escape (crustal extrusion) of terranes continues along major dextral-slip faults, including the Denali (DE), Nixon Fork (NF), Kaltag (KA), and companion faults (Scholl and others, 1992, 1994), which may extend into the Bering Sea. Dextral-wrench basins continue to form in association with the dextral-slip faults and are still filling with continental sedimentary materials. A thick sedimentary prism continues to form in the Aleutian-Bowers Basin (atb) (Plafker and Berg, 1994). In interior and southern Alaska, displacement continues along major dextral-slip faults, such as the Denali Fault (DE).

6. The Pacific oceanic plate (PAC) continues to migrate northwestward relative to the North American plate. Along the Aleutian megathrust (AL), plate convergence continues to range from orthogonal in the east to oblique to transform in the west.

7. Intense tectonic disruption continues in the western part of Aleutian-Wrangell arc along the western Aleutian megathrust $(\mathrm{AL})$, as a result of transform coupling between the Pacific oceanic plate (PAC) and the North American plate (Geist and others, 1988; Scholl and others, 1992, 1994). A thick sedimentary prism continues to form in the Aleutian-Bowers Basin (atb) that overlies a fragment of accreted Kula oceanic plate (Plafker and Berg, 1994).

8. Along the margin of southern Alaska, the eastern part of the Aleutian-Wrangell arc continues activity. Associated with this arc is mainly oblique subduction of the north edge of the Pacific oceanic plate (PAC) along the Aleutian megathrust (AL), and continuing formation of the younger part of the Prince William terrane (PW). The Yakutat terrane (YA) continues to migrate northwestward and to underthrust the Prince William terrane (PW) along the eastern part of the Aleutian megathrust (AL).

9. Sea-floor spreading continues along the Juan de Fuca oceanic ridge (JFR). Northward movement of the Pacific oceanic plate (PAC) continues with transform displacement on the Queen Charlotte transform fault (QC).

10. The Cascade continental-margin arc continues to form. Associated with this arc is subduction of part of the Juan de Fuca oceanic plate (JF) and formation of a subductionzone complex along the Cascadia megathrust (CC) (table 2) (Goldfinger and others, 1996, 1997; Flueh and others, 1997).

\section{Conclusions}

The Cenozoic and Mesozoic, and some of the Paleozoic, evolution of the Circum-North Pacific can be explained as a succession of arcs and tectonically paired subduction zones that formed along the margins of the Northeast Asian and North American plates above the subducting oceanic lithosphere of mainly the Mongol-Okhotsk, Cache Creek, ancestral Pacific, and Pacific Oceans. In both Northeast Asia and the North American Cordillera, most of the arcs formed near continental margins as island arcs or along the continental margins. With respect to Northeast Asia and North America, the paleopositions of those arcs, which occur oceanward of coeval accretionary complexes, are highly suspect in the Paleozoic but successively less so in the Mesozoic. No compelling evidence exists to suppose that most of these arcs migrated across ocean basins. Geologic and faunal data and interpretations suggest formation mostly along the active margin of the Northeast Asian and North American plates. Some arcs may have formed at sites far removed from continents and have been subsequently emplaced by Mesozoic lateral displacements and rotations. The only truly exotic rocks in the North American Cordillera tectonic collage may be (1) parts of accretionary complexes that are composed mainly of oceanic-crustal material containing a Tethyan fauna that is exotic with respect to North America, (2) those terranes in western Alaska (Nixon Fork-Dillinger-Mystic) that are interpreted as fragments of the North Asian Craton and cratonal margin, and (3) the Late Proterozoic and early Paleozoic part of the Alexander sequence of the Wrangellia superterrane.

The Phanerozoic tectonic evolution is most simply explained by a model that consists of six main themes: (1) rifting of the northeastern margin of the North Asian Craton and the northwestern margin of the North American Craton;

(2) formation of successions of single island arcs and tectonically paired subduction-zone complexes along or near the North Asian and North American cratonal margins, above subducting oceanic plates of the ancestral Pacific and modern Pacific Oceans; (3) formation of a succession of continentalmargin arcs and tectonically paired subduction zones; (4) oblique accretion of arcs and companion subduction-zone complexes onto the northeastern margin of the North Asian Craton and the northwestern margin of the North American Craton, resulting in substantial growth of both continents; (5) deposition of overlap assemblages, mainly derived from continental-margin igneous arcs, onto previously accreted terranes; and (6) strike-slip translation of previously accreted arc/ subduction-zone complexes, overlap assemblages, and fragments of continental margins along the margins of the cratons.

\section{References Cited}

Afitsky, A.I., 1970, Biostratigraphy of Triassic and Jurassic deposits in the vicinity of the Bolshoy Anyui River: Moscow, Nauka, 150 p. [in Russian].

Afitsky, A.I., and Lychagin, P.P., 1987, Norian andesitic volcanism of Oloy zone: Tikhookeanskaya Geologiya, no. 3, p. 77-82 [in Russian]. 
Aleksyutin, M.V., and Shipunov, S.V., 1997, Synfolding magnetization of rocks of the Kuyul' Nappe System, Penzinha district, northeastern Russia: Physics of the Earth Izvestiya, v. 33, p. 279-284.

Amato, J.M., and Wright, J.E., 1997, Potassic mafic magmatism in the Kigluaik gneiss dome, northern Alaska; a geochemical study of arc magmatism in an extensional tectonic setting: Journal of Geophysical Research, v. 102, no. 4, p. 8065-8084.

Anderson, R.G., 1989, A stratigraphic, plutonic, and structural framework for the Iskut River map area, northwestern British Columbia, in Current research, part E: Geological Survey of Canada Paper 89-1E, p. 145-154.

-1993, A Mesozoic stratigraphic and plutonic framework for northwestern Stikinia (Iskut river area), northwestern British Columbia, Canada, in Dunne, G., and McDougall, K.A., eds., Mesozoic paleogeography of the western United States-II: Los Angeles, Society of Economic Paleontologists and Mineralogists, Pacific Section, v. 71, p. 447-494.

Andrew, K.P.E., Hoy, T., and Drobe, J., 1990, Stratigraphy and tectonic setting of the Archibald and Elise Formations, Rossland Group, Beaver Creek area, southeastern British Columbia, in Geological fieldwork: 1989, British Columbia Ministry of Energy, Mines, and Petroleum Resources, Paper 1990-1, p. 19-27.

Archegov, V.B., Golovin, S.V., Zinchenko, V.N., Kirillov, V.O., and Chochia, N.G., 1987, Basins of the Priverkhoyansk marginal system; sedimentary basins of the U.S.S.R. Far East and prospects of their oil- and gas-bearing capacity: Leningrad, Nedra, p. 60-91 [in Russian].

Archibald, D.A., Glover, J.K., Price, R.A., Farrar, E., and Carmichael, D.M., 1983, Geochronology and tectonic implications of magmatism and metamorphism, southern Kootenay arc and neighbouring regions; part 1, Jurassic to mid-Cretaceous: Canadian Journal of Earth Sciences, v. 20, p. 1891-1913.

Argand, E., 1924, La tectonique de l'Asie: Congrès Géologique International 13er Comptes Rendus, Belgique, 1922, p. 171-372 [in French].

Armstrong, R.L., 1988, Mesozoic and early Cenozoic magmatic evolution of the Canadian Cordillera, in Clark, S.P., Burchfiel, B.C., and Suppe, J., eds., Processes in continental lithospheric deformation: Geological Society of America Special Paper 218, p. 55-91.

Armstrong, R.L., and Ward, P.L., 1993, Late Triassic to earliest Eocene magmatism in the North American Cordillera: implications for the Western Interior Basin, in Caldwell, W.G.E., and Kauffman, E.G., eds., Evolution of the western interior basin: Geological Association of Canada Special Paper 39, p. 49-72.

Atwater, Tanya, 1989, Plate tectonic history of the northeast Pacific and western North America, in Winterer, E.L., Jussong, D.M., and Decker, R.W., eds., The eastern Pacific Ocean and Hawaii (The Geology of North America, v. N): Boulder, Colo., Geological Society of America, p. 21-72.

Atwater, Tanya, and Severinghaus, Jeff, 1989, Tectonic map of the north-central Pacific Ocean, pls. 3A-3C of Winterer, E.L., Hussong, D.M., and Decker, R.W., eds., The eastern Pacific Ocean and Hawaii (The geology of North America, v. N): Boulder, Colo., Geological Society of America, scale 1:6,442,194.

Avchenko, 0.V., 1977, Petrology of Okhotsk metamorphic complex: Moscow, Nauka, 95 p. [in Russian].

Babcock, L.E., and Blodgett, R.B., 1992, Biogeographic and paleogeographic significance of Middle Cambrian trilobites of Siberian aspect from southwestern Alaska [abs.]: Geological Society of America Abstracts with Programs, v. 24, no. 5, p. 4.

Babcock, L.E., Blodgett, R.B., and St. John, James, 1993, Proterozoic and Cambrian stratigraphy and paleontology of the Nixon Fork terrane: Circum-Pacific and Circum-Atlantic Terrane Conference, Guanajuato, Mexico, 1993, Proceedings, p. 5-7.

Babcock, R.S., Burmester, R.F., Engebretson, D.C., Warnock, D., 1992, A rifted-margin origin for the Crescent Basalts and related rocks from the northern Coast Range volcanic province of Washington and British Columbia: Journal of Geophysical Research, v. 97, no. B, p. 6799-6821.

Babcock, R.S., Suczek, C.A., and Engebretson, D.C., 1994, The Crescent terrane, Olympic Peninsula and southern Vancouver Island: Washington Division of Geology and Earth Sciences Bulletin, v. 80, p. 141-157.

Baboshina, V.A., Tereshchenkov, A.A., and Kharakhinov, V.V., 1984, Deep structure of the Sea of Okhotsk region from geophysical data. Review of information: Moscow, VNII Gasprom, v. 3, 41 p. [in Russian]. 1985, Gravitational field of the Sea of Okhotsk region and its interpretation in concert with bathymetry and seismic data: Tikhookeanskaya Geologiya, no. 6, p. 49-59 [in Russian].

Bakharev, A.G., 1976, Stratigraphy and composition of the Ul'ya basin, in Volcanic and intrusive formations in Priokhot'e: Novosibirsk, Nauka, p. 53-75 [in Russian].

Bakharev, A.G., Gamyanin, G.N., Goryachev, N.A., and Polovinkin, V.L., 1988, Magmatism and ore formations of the Ulakhan-Tas Range: Yakutsk, Soviet Union Academy of Sciences, 200 p. [in Russian].

Baranov, B.V., Seliverstov, N.I., Muravov, A.V., and Muzuzov, E.L., 1991, The Komandorsky Basin as a product of spreading behind a transform plate boundary: Tectonophysics, v. 199, p. 237-269.

Bardous, M., and Irving, E., 1989, Paleomagnetism of Eocene rocks of the Kelowna and Castlegar areas, British Columbia: studies in determining paleohorizontal: Canadian Journal of Earth Sciences, v. 26, p. 829-844.

Barker, Fred, Sutherland-Brown, A., Budahn, J.R., and Plafker, George, 1989, Back-arc with frontal-arc component origin of Triassic Karmutsen basalt, British Columbia, Canada: Chemical Geology, v. 75, p. 81-102.

Barker, Fred, Miller, T.P., and Gehrels, G.E., 1994, Map showing occurrences of accreted volcanic rocks and the pre-Cenozoic and some early Tertiary plutonic rocks of Alaska, pl. 13 of Plafker, George, and Berg, H.C., eds., The geology of Alaska (The Geology of North America, v. G-1): Boulder, Colo., Geological Society of America, scale 1:2,500,000.

Barton, P., and Wood, R.,. 1984, Tectonic evolution of the North Sea Basin; crustal stretching and subsidence: Geophysical Journal of Royal Astronomical Society, v. 79, p. 987-1922.

Bazard, D.R., Butler, R.F., Gehrels, G.E., 1993, Paleomagnetic and detrital zircon analysis of the Lower Devonian Karheen Formation, Alexander Terrane, southeastern Alaska [abs.]: Eos (American Geophysical Union Transactions), v. 74, p. 213.

Bazard, D.R., Butler, R.F., Gehrels, G.E., and Soja, C.M., 1994, New constraints for Late Silurian-Devonian paleogeography of the Alexander terrane, southeastern Alaska [abs.]: Geological Society of America Abstracts with Programs, v. 26, p. 384.

Bazhenov, M.L., and Burtman, V.S., 1992, Paleomagnetism of Paleogene rocks of the Central-East Kamchatka and Komandordky Islands; tectonic implications: Tectonophysics, v. 201, p. 157-173.

1996, Upper Cretaceous paleomagnetism of the Shikotan Island; implications for plate kinematics: Earth and Planetary Science Letters, v. 122, p. 19-28.

Bazhenov, M.L., Burtman, V.S., Krezhovskikh, O.A., Shapiro, M.N., 1992, Paleomagnetism of Paleogene rocks of the central-east 
Kamchatka and Komanorsky Islands; tectonic implications: Tectonophysics, v. 201, p. 157-173.

Bekhtold, A.F., and Semenov, D.F., 1990, Metabasites and ultramafic rocks of the Susunai Ridge (Sakhalin Island): Tikhookeanskaya Geologiya, no. 1, p. 121-125 [in Russian].

Belasky, P., and Runnegar, B., 1994, Permian longitudes of Wrangellia, Stikinia, and eastern Klamath terranes based on coral biogeography: Geology, v. 22, p. 1095-1098.

Belyaeva, G.V., 1988, The Cambrian of the U.S.S.R. East; stratigraphy: Moscow, Nauka, 136 p. [in Russian].

Belyi, V.F., 1977, Stratigraphy and structures of the Okhotsk-Chukotka volcanic belt: Moscow, Nauka, 171 p. [in Russian].

1978, Formations and tectonics of the Okhotsk-Chukotka volcanic belt: Moscow, Nauka, 213 p. [in Russian].

Berg, H.C., Jones, D.L., and Richter, D.H., 1972, Gravina-Nutzotin Belt: tectonic significance of an upper Mesozoic sedimentary and volcanic sequence in southern and southeastern Alaska, in Geological Survey research, 1972: U.S. Geological Survey Professional Paper 800-D, p. D1-D4.

Bersenev, I.I., Lelikov, E.P., Bezverkhny, V.L., Vashchenkova, N.G., S'edin, V.G., Terekhov, E.P., and Tsoi, I.B., 1987, Geology of the Philippine Sea Floor: Vladivostok, U.S.S.R. Academy of Sciences, Far East Branch, 138 p. [in Russian].

Besse, J., and Courtillot, V., 1991, Revised and synthetic apparent polar wander paths of African, Eurasian, North American and Indian plates, and true polar wander since $200 \mathrm{Ma}$ : Journal of Geophysical Research, v. 96, no. B, p. 4029-4050.

Beus, V.A., and Miledin, A.K., 1990, New data on the age of the metamorphic complex of the Prikolyma uplift: Akademii Nauk SSSR Doklady, v. 311, p. 925-928 [in Russian].

Bevier, M.L., 1988, Regional stratigraphy and age of Chilcotin Group basalts, south-central British Columbia: Canadian Journal of Earth Sciences, v. 20, p. 515-524.

Bibikova, E.V., Makrov, V.A., Gracheva, T.V., and Kalinkina, O.M., 1981, Ancient rocks of the Omolon massif, in Ancient granitoids of the U.S.S.R.: Leningrad, Nauka, p. 137-146 [in Russian].

Blodgett, R.B., 1998, Emsian (late Early Devonian) fossils indicate a Siberian origin for the Farewell terrane, in Clough, J.G., and Larson, F., eds., Short notes on Alaska geology 1997: Alaska Division of Geological and Geophysical Surveys Professional Report 118, p. 53-61.

Blodgett, R.B., and Boucot, A.J., 1999, Late Early Devonian (Late Emsian) eospiriferoid brachiopods from Shallabarger Pass, south-central Alaska, and their biogeographic importance: Senckenbergiana Lethaea, v. 79, p. 209-221.

Blodgett, R.B., and Brease, P.F., 1997, Emsian (Early Devonian) brachiopods from Shellabarger Pass, Talkeetna C-6 quadrangle, Denali National Park, Alaska, indicate Siberian origin for Farewell terrane [abs.]: Geological Society of America Abstracts with Programs, v. 29, p. 5.

Blodgett, R.B., and Clough, J.G., 1985, The Nixon Fork terrane-part of an in-situ peninsular extension of the Paleozoic North American continent [abs.]: Geological Society of America Abstracts with Programs, v. 17, p. 342.

Blodgett, R.B., and Gilbert, W.G., 1992, Upper Devonian shallowmarine siliciclastic strata and associated fauna and flora, Lime Hills D-4 quadrangle, southwest Alaska, in Bradley, D.C., and Dusel-Bacon, Cynthia, eds., Geological studies in Alaska by the U.S. Geological Survey, 1991: U.S. Geological Survey Bulletin 2041, p. 106-113.

Blois, C., and ECORS Scientific Parties, 1991, Post-orogenic evolution of the European crust studied from ECORS deep seismic profiles, in Meissner, R., Brown, L, Durbaum, H.J., Franke, W.,
Fuchs, K., and Seifert, F., eds., Continental lithosphere; deep seismic reflections: American Geophysical Union Geodynamics Series, v. 22, p. 59-68.

Boak, J.M., Turner, D.L., Henry, D.J., Moore, T.E., and Wallace, W.K., 1987, Petrology and K-Ar ages of the Misheguk igneous sequence, an allochthonous mafic and ultramafic complex, and its metamorphic aureole, western Brooks Range, Alaska, in Tailleur, I.L., and Weimer, Paul, eds., Alaskan North Slope geology: Los Angeles, Society of Economic Paleontologists and Mineralogists, Pacific Section, and Alaska Geological Society, v. 50, p. 737-745.

Bogdanov, N.A., and Til'man, S.M., 1992, Tectonic map of Northeastern Asia: Moscow, Russian Academy of Sciences, Institute of Lithosphere, and Circum-Pacific Council for Energy and Mineral Resources, scale 1:5,000,000.

Bogue, S.W., Grommé, S., and Hillhouse, J.W., 1995, Paleomagnetism, magnetic anisotropy, and mid-Cretaceous paleolatitude of Duke Island (Alaska) ultramafic complex: Tectonics, v. 14, p. 1133-1152.

Bol, A.J., 1993, Overprint magnetization in support of northward displacement of the Chugach-Prince William Terrane, Alaska: Journal of Geophysical Research, v. 98, no. B, p. 22389-22400.

Bol, A.J., Coe, R.S., Grommé, C.S., Hillhouse, J.W., 1992, Paleomagnetism of the Resurrection Peninsula, Alaska; implications for the tectonics of southern Alaska and the Kula-Farallon Ridge: Journal of Geophysical Research, v. 97, no. B, p. 17213-17232.

Box, S.E., 1985a, Early Cretaceous orogenic belt in northwestern Alaska; internal organization, lateral extent, and tectonic interpretation, in Howell, D.G., ed., Tectonostratigraphic terranes of the Circum-Pacific region (Earth Science Series, v. 1): Houston, Tex., Circum-Pacific Council for Energy and Mineral Resources, p. 137-145.

-1985b, Geologic setting of high-pressure metamorphic rocks, Cape Newenham area, southwestern Alaska, in Bartsch-Winkler, Susan, ed., The United States Geological Survey in Alaska; accomplishments during 1984: U.S. Geological Survey Circular 967, p. 37-42.

1985c, Terrane analysis, northern Bristol Bay region, southwestern Alaska, in Bartsch-Winkler, Susan, ed., The United States Geological Survey in Alaska; accomplishments during 1984: U.S. Geological Survey Circular 967, p. 32-36.

Box, S.E., Moll-Stalcup, E.J., Frost, T.P., and Murphy, J.M., 1993, Preliminary geologic map of the Bethel and southern Russian Mission quadrangles, southwestern Alaska: U.S. Geological Survey Miscellaneous Field Studies Map MF-2226-A, 20 p., scale 1:250,000.

Box, S.E., Moll-Stalcup, E.J., and Wooden, J.L., 1990, Kilbuck terrane; oldest-known rocks in Alaska: Geology, v. 18, p. 1219-1222.

Box, S.E., and Patton, W.W., Jr., 1989, Igneous history of the Koyukuk terrane, western Alaska; constraints on the origin, evolution, and ultimate collision of an accreted island arc terrane: Journal of Geophysical Research, v. 94, no. B, p. 15843-15867.

Bradley, D.C., Haeussler, P., and Kusky, T.M., 1993, Timing of early Tertiary ridge subduction in southern Alaska, in Dusel-Bacon, Cynthia, and Till, A.B., eds., Geologic studies in Alaska by the U.S. Geological Survey, 1992: U.S. Geological Survey Bulletin 2068, p. 163-177.

Brandon, M.T., 1989, Geology of the San Juan-Cascade Nappes, Northwestern Cascade Range and San Juan Islands, in Joseph, N.L., and others, eds., Geologic guidebook for Washington and adjacent areas: Washington Division of Geology and Earth Resources Information Circular 86, p. 137-162.

Brandon, M.T., Garver, J.I., Bullen, M.E., Sokovév, A.V., Ledneva, G.V., 
and Bogdanov, N.A., 1997, Eocene collision and obduction of the Olutorskiy island arc, Koryak Highlands of northern Kamchatka, Russian Far East [abs.]: Geological Society of America Abstracts with Programs, v. 29, p. 6.

1998, Eocene collision and obduction of the Olutorskiy island arc, Koryak Highlands of northern Kamchatka, Russian Far East [abs.]: Russian Academy of Sciences' L.P. Zonenshain Conference on Plate Tectonics, 6th, Moscow, 1998, Abstracts, v. 29, p. 172.

Brooks, H.C., and Vallier, T.L., 1978, Mesozoic rocks and tectonic evolution of eastern Oregon and western Idaho, in Howell, D.G., and McDougall, K.A., eds., Mesozoic paleogeography of the western United States: Los Angeles, Society of Economic Paleontologists and Mineralogists, Pacific Section, Pacific Coast Paleogeography Symposium 2, p. 133-145.

Brown, D.A., Logan, J.M., Gunning, M.H., Orchard, M.J., and Bamber, W.E., 1991, Stratigraphic evolution of the Paleozoic Stikine assemblage in the Stikine and Iskut Rivers area, northwestern British Columbia: Canadian Journal of Earth Sciences, v. 28, no. 6, p. 958-972.

Bulgakova, M.D., 1986, Lithology of Ordovician deposits in northeastern U.S.S.R.: Moscow, Nauka, 177 p. [in Russian].

Bundtzen, T.K., and Gilbert, W.G., 1983, Outline of the geology and mineral resources of the upper Kuskokwim region, southwest Alaska, in Sisson, Alex, ed., Symposium on Energy and Mineral Resources of western Alaska: Journal of Alaska Geological Society, v. 3, p. 98-119.

Bundtzen, T.K., Kline, J.R., Smith, T.E., and Albanese, M.A., 1988, Geology of the McGrath A-2 quadrangle, western Alaska: Alaska Division of Geological and Geophysical Surveys Professional Report 91, 10 p., scale 1:63,360.

Bundtzen, T.K., and Miller, M.L., 1997, Precious metals associated with Late Cretaceous-early Tertiary igneous rocks of southwestern Alaska, in Goldfarb, R.J., and Miller, L.D., eds., Mineral deposits of Alaska: Economic Geology Monograph 9, p. 242-286.

Burchfiel, B.C., 1992, Tectonostratigraphic map, Cordilleran orogen, conterminous United States, pl. 1A of Burchfiel, B.C., Lipman, P.W., and Zoback, M.L., eds., The Cordilleran Orogen; conterminous United States (The Geology of North America, v. G-3): Boulder, Colo., Geological Society of America, 2 sheets, scale $1: 2,500,000$.

Burchfiel, B.C., and Davis, G.A., 1972, Structural framework and evolution of the southern part of the Cordilleran orogen, western United States: American Journal of Science, v. 272, p. 97-118.

Butler, R.F., Gehrels, G.E., and Bazard, D.R., 1997, Paleomagnetism of Paleozoic strata of the Alexander terrane, southeastern Alaska: Geological Society of America Bulletin, v. 109, p. 1372-1388.

Butler, R.F., Gehrels, G.E., McClelland, W.C., May, S.R., Klepacki, D., 1989, Discordant paleomagnetic poles from the Canadian Coast plutonic complex; regional tilt rather than large-scale displacement?: Geology, v. 17, p. 691-1989.

Butler, R.F., Harms, T.A., and Gabrielse, H., 1988, Cretaceous remagnetization in the Sylvester Allochthon; limits to post-105 Ma northward displacement of north-central British Columbia: Canadian Journal of Earth Sciences, v. 25, p. 1316-1322.

Burns, L.E., 1985, The Border Ranges ultramafic and mafic complex, south-central Alaska; cumulate fractionates of island-arc volcanics: Canadian Journal of Earth Sciences, v. 22, p. 1020-1038.

Byalobzhesky, S.G., Kolyasnikov, Y.A., and Schmakin, V.B., 1986, Tectonics of the active continental margin (Koyrak Upland):
Magadan, U.S.S.R. Academy of Sciences, Northeast Scientific Research Institute, 246 p. [in Russian].

Byalobzhesky, S.G., Korago, E.A., Lychagin, P.P., Kolyasnikov, Yu.A., and Likman, V.B., 1990, South Anyui zone; long-lived development of folded structure, in Tectonics and metallogeny of U.S.S.R. Northeast: Magadan, U.S.S.R. Academy of Sciences, p. 29-31 [in Russian].

Bychkov, Yu.M., and Kiseleva, L.S., 1990, Local subdivisions of the Triassic in the upper Kolyma, Yana, and Tauy Rivers: Magadan, U.S.S.R. Academy of Sciences, 55 p. [in Russian].

Bychkov, Yu.M., Byalobzhesky, S.G., and Petrov, A.N., 1990, First findings of Early and Middle Jurassic fauna in the eastern Koryak Highland: Akademii Nauk SSSR Doklady, v. 312, p. 1181-1189 [in Russian].

Cant, D.J., 1989, Zuni sequence; the Foreland Basin, Lower Zuni sequence; Middle Jurassic to Middle Cretaceous, in Ricketts, B.D., ed., Western Canada sedimentary basin; a case history: Calgary, Canadian Society of Petroleum Geologists, p. 251-267.

Chikov, B.M., 1978, Median massifs and problems of tectonic zoning of orogenic belts: Novosibirsk, Nauka, 249 p. [in Russian].

Churkin, M., Jr., and Carter, Claire, 1996, Stratigraphy, structure, and graptolites of an Ordovician and Silurian sequence in the Terra Cotta Mountains, Alaska Range, Alaska: U.S. Geological Survey Professional Paper 1555, 84 p.

Clowes, R.M., Brandon, M.T., Green, A.G., Yorath, C.J., Sutherland Brown, A., Kanasewich, E.R., and Spencer, C., 1987, LITHOPROBE-southern Vancouver Island; Cenozoic subduction complex imaged by deep seismic reflections: Canadian Journal of Earth Sciences, v. 24, p. 31-51.

Cluzel, D., 1990, Geodynamics of the Ogcheon Belt, South Korea: Tectonophysics, v, 183, p. 41-56.

1991, Late Paleozoic to early Mesozoic geodynamic evolution of the Circum-Pacific orogenic belt in Korea and southwest Japan: Earth and Planetary Science Letters, v. 108, p. 289-305.

Cluzel, D., Lee, B.-J., and Cadet, J.-P., 1991, Indonesian dextral-ductile fault system and synkinematic plutonism in the southwestern Ogcheon belt, South Korea: Tectonophysics, v. 194, p. 131-151.

Coe, R.S., Globerman, B.R., Plumley, P.W., and Thrupp, G.A., 1985, Paleomagnetic results from Alaska and their tectonic implications, in Howell, D.G., ed., Tectonostratigraphic terranes of the Circum Pacific Region (Earth Science Series, v. 1): Houston, Tex., Circum-Pacific Council for Energy and Mineral Resources, p. 85-108.

Coe, R.S., Globerman, B.R., and Thrupp, G.A., 1988, Rotation of central and southern Alaska in the early Tertiary; oroclinal bending by megakink?, in Kissel, C., and Laj, C., eds., Paleomagnetic rotations and continental deformation (NATO ser. C): Dordrecht, Holland, Kluwer Academic Publications, p. 327-342.

Cohen, H.A., and Lundberg, N., 1993, Detrital record of the Gravina arc, southeastern Alaska; petrology and provenance of Seymour Canal Formation sandstones: Geological Society of America Bulletin, v. 105, p. 1400-1414.

Coney, P.J., Jones, D.L., and Monger, J.W.H., 1980, Cordilleran suspect terranes: Nature, v. 288, p. 29-33.

Cook, D.B., Fujita, Kazuya, and McMullen, C.A., 1986, Present-day plate interactions in northeast Asia; North American, Russian, and Okhotsk plates: Journal of Geodynamics, v. 6, p. 33-51.

Cook, F.A., 1995, Lithospheric processes and products in the southern Canadian Cordillera; a lithoprobe perspective: Canadian Journal of Earth Sciences, v. 32, p. 1803-1824.

Cooper, A.K., Scholl, D.W., and Marlow, M.S., 1987, Structural framework, sedimentary sequences, and hydrocarbon potential of the Aleutian and Bowers Basins, Bering Sea, in Scholl, D.W., 
Grantz, Art, and Vedder, J.G., eds., Geology and resource potential of the continental margin of western North America and adjacent ocean basins-Beaufort Sea to Baja California (Earth Science Series, v. 6): Houston, Tex., Circum-Pacific Council for Energy and Mineral Resources, p. 473-502. 1992, Evidence for Cenozoic crustal extension in the Bering Sea region: Tectonics, v. 11, p. 719-731.

Cordey, F., Gordy, S., and Orchard, M.H., 1991, New biostratigraphic data for the northern Cache Creek terrane, Teslin map area, in Current research, part E: Geological Survey of Canada Paper 91-1E, p. 67-76.

Cordey, F., Mortimer, N., De Wever, P., and Monger, J.W.H., 1987, Significance of Jurassic radiolarians from the Cache Creek terrane, British Columbia: Geology, v. 15, p. 1151-1154

Cordey, F., and Schiarizza, P.F., 1993, Long-lived Panthalassic remnant; the Bridge River accretionary complex, Canadian Cordillera: Geology, v. 21, p. 263-266.

Cowan, D.S., 1982, Geological evidence for post-40 m.y. B.P. largescale northwestward displacement of part of southeastern Alaska: Geology, v. 10, p. 309-313.

1994, Alternative hypotheses for the mid-Cretaceous paleogeography of the western Cordillera: GSA Today, v. 4, no. 7, p. 181-186.

Cowan, D.S., Brandon, M.T., and Garver, J.I., 1997, Geologic tests for large coastwise displacements - a critique illustrated by the Baja British Columbia controversy: American Journal of Science, v. 297, p. 117-173.

Dagis, A.C., and Dagis, A.A., 1984, The Triassic system, in The Phanerozoic of Siberia, the Mesozoic and Cenozoic: Novosibirsk, Nauka, v. 2, p. 4-15 [in Russian].

Dagis, A.S., Arkhipov, Yu.U., and Bychkov, Yu.M., 1979, Stratigraphy of the Triassic system in northeastern Asia: Moscow, Nauka, 243 p. [in Russian].

Dalziel, I.W.D., 1991, Pacific margins of Laurentia and East-Antarctica-Australia as a conjugate rift pair; evidence and implications for an Eocambrian supercontinent: Geology, v. 19, p. 598-601.

Davis, G.A., Monger, J.W.H., and Burchfiel, B.D., 1978, Mesozoic construction of the Cordilleran "collage," central British Columbia to central California, in Howell, D.G., and McDougall, K.A., eds., Mesozoic paleogeography of the western United States: Los Angeles, Society of Economic Paleontologists and Mineralogists, Pacific Section, Pacific Coast Paleogeography Symposium 2, p. 1-32.

Debari, S.M., and Coleman, R.G., 1989, Examination of the deep levels of an island arc; evidence from the Tonsina ultramaficmafic assemblage, Tonsina, Alaska: Journal of Geophysical Research, v. 94, no. B, p. 4373-4391.

Decisions of the Fourth Interdepartmental Regional Meeting on Precambrian and Phanerozoic of the Far East and Eastern Baikal Regions, 1994, Stratigraphic scheme of Jurassic deposits of southwestern Primorye: Khabarovsk, Khabarovskoye Gosudarstvennoye Gorno-Geologicheskoye Predpriyatiye, 31 tables [in Russian].

Decker, J., Bergman, S.C., Blodgett, R.B., Box, S.E., Bundtzen, T.K., Clough, J.G., Coonrad, W.L., Gilbert, W.G., Miller, M.L., Murphy, J.M., Robinson, M.S., and Wallace, W.K., 1994, Geology of southwestern Alaska, in Plafker, George, and Berg, H.C., eds., The geology of Alaska (The Geology of North America, v. G-1): Boulder, Colo., Geological Society of America, p. 285-310.

Detterman, R.L., Miller, J.W., Case, J.E., Wilson, F.H., and Yount, M.E., 1996, Stratigraphic framework of the Alaska Peninsula: U.S. Geological Survey Bulletin 1969-A, 74 p.
Dickinson, W.R., 1979, Mesozoic fore-arc basin in central Oregon: Geology, v. 7, p. 166-170.

Dickinson, W.R., and Butler, R.F., 1998, Coastal and Baja California paleomagnetism reconsidered: Geological Society of America Bulletin, v. 110, p. 1268-1280.

Dickinson, W.R., and Thayer, T.P, 1978, Paleogeographic and paleotectonic implications of Mesozoic stratigraphy and structure in the John Day inlier of central Oregon, in Howell, D.G., and McDougall, K.A., eds., Mesozoic paleogeography of the western United States: Los Angeles, Society of Economic Paleontologists and Mineralogists, Pacific Section, Pacific Coast Paleogeography Symposium 2, p. 147-161.

Didenko, A., Harbert, W., and Stavsky, A., 1993, Paleomagnetism of Khatyrian and Mayinsky terranes, Koryakian Highlands, northeast CIS: Tectonophysics, v. 220, p. 141-156.

Didenko, A., and Pechersky, D., 1993, Revised Paleozoic apparent polar wander paths for Eastern Europe, Siberia, Northern China, and Tarim plates [abs.]: Russian Academy of Sciences L.P. Zonenshain Memorial Conference on Plate Tectonics, Moscow, 1993, Abstracts with Program, p. 47.

Dobretsov, N.L., 1978, Glaucophane schist and eclogite-glaucophane schist units of the U.S.S.R.: Novosibirsk, Nauka, 430 p. [in Russian].

Drachev, S.S., and Savostin, L.A., 1992, Dismembered ophiolitic association of the New Siberian Islands; structural setting, composition, and interpretation [abs.]: International Conference on Arctic Margins, Anchorage, 1992, Program with Abstracts, p. 14.

Dudko, E.A., and Spektor, V.B., 1989, Northwestern continuation of the South Anyui fold zone in the lower reaches of the Kolyma (according to gravimetric and magnetometric data): Geologiya i Geofizika, no. 2, p. 21-31 [in Russian].

Dumoulin, J.A., 1988, Sandstone petrographic evidence and the Chugach-Prince William terrane boundary in southern Alaska: Geology, v. 16, p. 456-460.

Dumoulin, J.A., Bradley, D.C., Harris, A.G., and Repetski, J.E., 1999, Lower Paleozoic deep-water facies of the Medfra area, central Alaska, in Kelley, K.D., ed., Geologic studies in Alaska by the U.S. Geological Survey: U.S. Geological Survey Professional Paper 1614, p. 75-103.

1988, Sedimentology, conodont biogeography, and subsidence history of the Nixon Fork terrane, Medfra quadrangle, Alaska [abs.]: International Conference on Arctic Margins, 3d, Abstracts, p. 49.

Dumoulin, J.A., and Harris, A.G., 1987, Lower Paleozoic carbonate rocks of the Baird Mountains quadrangle, western Brooks Range, Alaska, in Tailleur, I.L., and Weimer, Paul, eds., Alaskan North Slope geology: Los Angeles, Society of Economic Paleontologists and Mineralogists, Pacific Section, and Alaska Geological Society, v. 50, p. 311-336.

Dusel-Bacon, Cynthia, Doyle, E.0., and Box, S.E., 1996, Distribution, facies, ages, and proposed tectonic associations of regionally metamorphosed rocks in southwestern Alaska and the Alaska Peninsula: U.S. Geological Survey Professional Paper 1497-B, p. B1-B30.

Dusel-Bacon, Cynthia, and Hansen, V.L., 1992, High-pressure, amphibolite-facies metamorphism and deformation within the Yukon-Tanana and Taylor Mountain terranes, eastern Alaska, in Bradley, D.C., and Dusel-Bacon, Cynthia, eds., Geological studies in Alaska by the U.S. Geological Survey, 1991: U.S. Geological Survey Bulletin 2041, p. 140-159.

Engebretson, D.C., Cox, A., and Gordon, R.C., 1985, Relative motions between oceanic and continental plates in the Pacific Basin: 
Geological Society of America Special Paper 106, $59 \mathrm{p}$.

Engebretson, D.C., Kelley, K.P., Cashman, H.P., and Richards, M.A., 1992, 180 million years of subduction: GSA Today, v. 2, p. 93-100.

England, P.C., and Wells, R.E., 1991, Neogene rotations and quasicontinuous deformation of the Pacific Northwest continental margin: Geology, v. 19, p. 978-981.

Erlikh, E.N., 1973, Modern structure and Quaternary volcanism of the western Pacific realm: Novosibirsk, Nauka, 242 p. [in Russian]

Evenchick, C.A., 1991, Geometry, evolution, and tectonic framework of the Skeena Fold Belt, north-central British Columbia: Tectonics, v. 10, p. 527-546.

Ewing, T.E., 1980, Paleogene tectonic evolution of the Pacific Northwest: Journal of Geology, v. 88, p. 619-638.

Faure, M., 1986, The Late Jurassic oblique collisional orogen of southwestern Japan; new structural data and synthesis: Tectonics, v. 5, p. 1089-1114.

Faure, M., and Natal'in, B.A., 1992, The geodynamic evolution of eastern Eurasian margin in Mesozoic times: Tectonophysics, v. 208, p. 397-411.

Fedorchuk, A.V., Tsukanov, N.V., Efremova, L.B., and Savichev, A.T., 1990, Oceanic magmatism of the Kumroch Range (eastern Kamchatka): Geokhimiya, no. 12, p. 1721-1729 [in Russian].

Fernette, Gregory, and Cleveland, Gregory, 1984, Geology of the Miss Molly molybdenum prospect, Toyonek $\mathrm{C}-6$ quadrangle, Alaska: Alaska Division of Geological and Geophysical Surveys Professional Report 86, p. 35-41.

Filatova, N.I., 1979, Cretaceous-Paleogene volcanism of the transition zone between the Verkhoyansk-Chukotka and Koryak-Kamchatka regions: Geotektonika, no. 5, p. 67-82 [in Russian]. 1988, Circum-oceanic volcanic belts: Moscow, Nedra, 264 p. [in Russian].

Fisher, R.A., 1953, Dispersion on a sphere: Royal Society of London Proceedings, ser. A, v. 217, p. 295-305.

Fitch, T.J., 1972, Plate convergence, transcurrent faults, and internal deformation adjacent to southeast Asia and western Pacific: Journal of Geophysical Research, v. 77, no. B, p. 4432-4460.

Flueh, E., Fisher, M., Scholl, D., Parsons, T., ten Brink, Uri, Klaeschen, D., Kukowski, N., Trehu, A., Childs, J., Bialas, J., and Vidal, N., 1997, Scientific teams analyze earthquake hazards of the Cascadia subduction zone: Eos (American Geophysical Union Transactions), v. 78, p. 153, 157.

Foster, H.L., Keith, T.E.C., and Menzie, W.D., 1994, Geology of the Yukon-Tanana area of east-central Alaska, in Plafker, George, and Berg, H.C., eds., The geology of Alaska (The Geology of North America, v. G-1): Boulder, Colo., Geological Society of America, p. 205-240.

Fryda, Jiri, and Blodgett, R.B., 1998, Two new Cirroidean genera (Vetigastropoda, Archaeogastropoda) from the Emsian (late Early Devonian) of Alaska with notes on the early phylogeny of Cirroidea: Journal of Paleontology, v. 72, p. 265-273.

Fujita, Kazuya, Cambray, F.W., and Velbel, M.A., 1990a, Tectonics of the Laptev Sea and Moma rift systems, northeastern U.S.S.R.: Marine Geology, v. 93, p. 95-118.

Fujita, Kazuya, and Cook, D.B., 1990, The Arctic continental margin of eastern Siberia, in Grantz, Art, Johnson, L., and Sweeney, J.F., eds., The Arctic Ocean region (The Geology of North America, v. L): Boulder, Colo., Geological Society of America, p. 289-304.

Fujita, Kazuya, Cook, D.B., Hasegawa, H., Forsyth, D., and Wetmiller, R., 1990b, Seismicity and focal mechanisms of the Arctic region and the North American plate boundary in Asia, in Grantz, Art, Johnson, L., and Sweeney, J.F., eds., The Arctic Ocean region (The Geology of North America, v. L): Boulder,
Colo., Geological Society of America, p. 79-100.

Fujita, Kazuya, Stone, D.B., Layer, P.W., Parfenov, L.M., and Koz'min, B.M., 1997, Cooperative program helps decipher tectonics of northeastern Russia: Eos (American Geophysical Union Transactions), v. 78, p. 245, 252-253.

Fujiwara, Y., and Ohtake, T., 1975, Paleomagnetism of Late Cretaceous alkaline rocks in the Nemuro Peninsula: Journal of Geomagnetism and Electricity, v. 26, p. 549-558.

Gabrielse, H., 1985, Major dextral transcurrent displacements along the Northern Rocky Mountain Trench and related lineaments in north-central British Columbia: Geological Society of America Bulletin, v. 96, p. 1-14.

1991, Late Paleozoic and Mesozoic terrane interactions in north-central British Columbia: Canadian Journal of Earth Sciences, v. 28, p. 947-957.

Gabrielse, H., and Yorath, C.J., eds., 1991, Geology of the Cordilleran Orogen, Canada (Geology of Canada, no. 4): Geological Survey of Canada, 844 p. [also Boulder, Colo., Geological Society of America, The geology of North America, v. G-2, 844 p.].

Gaiduk, V.V., 1988, The middle Paleozoic Vilyui rift system: U.S.S.R. Academy of Sciences, Yakutian Scientific Center, 127 p. [in Russian].

Gaiduk, V.V., Grinenko, O.V., and Syundyukov, I.Sh., 1993, Age of folding in the Moma Zyryanka basin: Tikhookeanskaya Geologiya, no. 3, p. 99-108 [in Russian].

Gaiduk, V.V., Syundyukov, I.Sh., Grinenko, O.V., and Imaev, V.S., 1989, Structure and oil and gas potential of the Cenozoic IndigirkaZyryanka Basin; tectonics and oil and gas prospecting in Yakutia: U.S.S.R. Academy of Sciences, Yakutian Scientific Center, p. 75-87 [in Russian].

Gardner, M.C., Bergman, S.C., Cushing, G.W., Mackevett, E.M., Jr., Plafker, George, Campbell, R.B., Dodds, C.J., McClelland, W.C., and Mueller, P.A., 1988, Pennsylvanian pluton stitching of Wrangellia and the Alexander Terrane, Wrangell Mountains, Alaska: Geology, v. 16, p. 967-971.

Garver, J.I., 1992, Provenance of Albian-Cenomanian rocks of the Methow and Tyaughton Basins, southern British Columbia; a mid-Cretaceous link between North America and Insular terranes: Canadian Journal of Earth Sciences, v. 96, p. 1-14.

Garver, J.I., Brandon, M.T., and Soloviev, A.V., 1998, Source of Ukelayat flysch and collision of the Olutorsky arc, northern Kamchatka, Russian Far East [abs.]: Geological Society of America Abstracts with Programs, v. 30, p. A269.

Gehrels, G.E., and Berg, H.C., 1992, Geologic map of southeastern Alaska: U.S. Geological Survey Miscellaneous Investigations Series Map I-1867, 24 p., scale 1:600,000.

1994, Geology of southeastern Alaska, in Plafker, George, and Berg, H.C., eds., The geology of Alaska (The Geology of North America, v. G-1): Boulder, Colo., Geological Society of America, p. 451-468.

Gehrels, G.E., McClelland, W.C., Samson, S.D., and Patchett, P.J., 1991, U-Pb geochronology of detrital zircons from a continental margin assemblage in the northern Coast Mountains, southeastern Alaska: Canadian Journal of Earth Sciences, v. 28, p. 1285-1300.

Gehrels, G.E., McClelland, W.C., Samson, S.D., Patchett, P.J., and Jackson, J.L., 1990, Ancient continental margin assemblage in the northern Coast Mountains, southeast Alaska and northwest Canada: Geology, v. 18, p. 208-211.

Gehrels, G.E., and Saleeby, J.B., 1987, Geologic framework, tectonic evolution, and displacement history of the Alexander terrane: Tectonics, v. 6, p. 151-173.

Geist, E.L., Childs, J.R., and Scholl, D.W., 1988, The origin of the 
summit basins of the Aleutian Ridge; implications for block rotation of an arc massif: Tectonics, v. 7, p. 327-341.

Geist, E.L., Vallier, T.L., and Scholl, D.W., 1994, Origin, transport, and emplacement of an exotic island-arc terrane exposed in eastern Kamchatka, Russia: Geological Society of America Bulletin, v. 106, p. 1182-1194.

Geology of the U.S.S.R., 1970, Sakhalin Island: Moscow, Nedra, v. 33, 430 p. [in Russian].

Gilbert, W.G., and Bundtzen, T.K., 1984, Stratigraphic relationships between Dillinger and Mystic terranes, western Alaska Range, Alaska [abs.]: Geological Society of America Abstracts with Programs, v. 16, p. 286.

Ghosh, D.K., 1995, Nd-Sr isotopic constraints on the interactions of the Intermontane superterrane with the western edge of North America in the southern Canadian Cordillera: Canadian Journal of Earth Sciences, v. 32, p. 1740-1758.

Globerman, B.R., and Coe, R.S., 1983, Paleomagnetic results from Upper Cretaceous volcanic rocks in northern Bristol Bay, southwest Alaska, and tectonic implications, in Howell, D.G., Jones, D.L., Cox, A., and Nur, A., eds., Proceedings of the Circum-Pacific Terrane Conference: Stanford, Calif., Stanford University Publications in Geological Sciences, p. 98-102.

Gnibidenko, G.S., Bykova, T.G., Veselov, O.V., Vorob'ev, V.M., Kim, Chun Un, and Tarakanov, R.Z., 1980, Tectonics of the KurilKamchatka trench: Moscow, Nauka, 179 p. [in Russian].

Gnibidenko, G.S., and Khnedchuki, I.I., 1982, The tectonics of the Okhotsk Sea: Marine Geology, v. 50, p. 155-198.

Gnibidenko, G.S., and Svarichevsky, A.S., 1984, Tectonics of the South Okhotsk deep-sea basin: Tectonophysics, v. 102, p. 225-244.

Goldfinger, C., Kulm, L.D., Yeats, R.S., McNeill, L.C., and Hummon, C., 1997, Oblique strike-slip faulting of the central Cascadia submarine forearc: Journal of Geophysical Research, v.102, no. B, p. 8217-8243.

Goldfinger, C., McNeil, L.C., Kulm, L.D., and Yeats, R.S., 1996, Width of the seismogenic plate boundary in Cascadia; structural indicators of strong and weak coupling [abs.]: Geological Society of America Abstracts with Programs, v. 28, p. 69.

Golionoko, B.G., 1992, Structural and geological development of the southern Kuril Island arc from the Late Cretaceous to Miocene in connection with the subduction of the Pacific plate: Moscow, Russian Academy of Sciences, Geological Institute, summary of Candidate of Science thesis, $23 \mathrm{p}$. [in Russian].

Golozubov, V.V., and Khanchuk, A.I., 1996, Taukha and Zhuravlevka terranes of the South Sikhote Alin-fragments of the Early Cretaceous margin of Asia: Geology of Pacific Ocean, v. 12, p. 203-220.

Golozubov, V.V., Khanchuk, A.I., Kemkin, I.V., Panchenko, I.V., and Simanenko, V.P., 1992, Taukha and Zuravlevka terranes of South Sikhote-Alin: Vladivostok, U.S.S.R. Academy of Sciences, 83 p. [in Russian].

Golozubov, V.V., and Melnikov, N.G., 1986, Tectonics of geosynclinal complexes of the South Sikhote-Alin: Vladivostok, U.S.S.R. Academy of Sciences, Far East Branch, $128 \mathrm{p}$.

Govorov, I.N., Golubeva, E.D., and Pushchin, I.K., 1996, Pacific petrological provinces: Moscow, Nauka, $444 \mathrm{p}$.

Grantz, Art, Clark, D.L., Phillips, R.L., and Srivastava, S.P., 1998, Phanerozoic stratigraphy of Northwind Ridge, magnetic anomalies in the Canada Basin, and the geometry and timing of rifting in the Amerasia basin, Arctic Ocean: Geological Society of America Bulletin, v. 110, p. 801-820.

Grantz, Art, Mayh, S.D., and Hart, P.E., 1990, Geology of the Arctic continental margin of Alaska, in Grantz, Art, Johnson, L., and Sweeney, J.F., eds., The Arctic Ocean region (The Geology of North America, v. L): Boulder, Colo., Geological Society of America, p. 257-288.

Grantz, Art, Moore, T.E., and Roeske, S.M., 1991, Transect A-3; Gulf of Alaska to Arctic Ocean: Geological Society of America, Centennial Continent/0cean Transect, no. 15, 3 sheets, scale $1: 500,000$.

Grapes, R., 1986, Mesozoic arc-trench development and Cenozoic orogeny of the North-West Pacific rim with special reference to Hokkaido: Osaka, Association for Geological Collaboration in Japan Monograph 31, p. 419-439.

Greninger, M.L., Klemperer, S.L., and Nokleberg, W.J., 1999, Geographic information systems (GIS) compilation of geophysical, geologic, and tectonic data for the Circum-North Pacific: U.S. Geological Survey Open-File Report 99-422, CD-ROM.

Grigor'yev, V.N., Krylov, K.A., and Sokolov, S.D., 1987, Jurassic-Cretaceous deposits of the Yanranaysk accretionary complex, in Essays on geology of northwestern sector of the Pacific tectonic belt: Moscow, Nauka, p. 110-140 [in Russian].

Grinberg, G.A., Gusev, G.S., Bakharev, A.G., 1981, Tectonics, magmatic, and metamorphic complexes of the Kolyma-Omolon Massif: Moscow, Nauka, 400 p. [in Russian].

Grommé, S., and Hillhouse, J.W., 1997, Paleomagnetic results from Devonian and Permian rocks at Saginaw Bay, Kuiu Island, southeastern Alaska: U.S. Geological Survey Professional Paper 1574, p. 295-306.

Hackett, D.J., Layer, P.W., Fujita, Kazuya, and Parfenov, L.M., 1992, Geochronology of granites in the Cherski Range, Yakutia, and implications for accretion of terranes to the Siberian craton [abs.]: Eos (American Geophysical Union Transactions), v. 73, p. 652.

Haeussler, P.J., 1992, Structural evolution of an arc-basin; the Gravina belt in central southeastern Alaska: Tectonics, v. 11, p. $1245-1265$.

Haeussler, P.J., Coe, R.S., and Onstott, T.C., 1992a, Paleomagnetism of the Late Triassic Hound Island volcanics revisited: Journal of Geophysical Research, v. 97, no. B, p. 19617-19640.

Haeussler, P.J., Coe, R.S., and Renne, P., 1992b, Paleomagnetism and geochronology of 23-Ma gabbroic intrusions in the Keku Strait, Alaska, and implications for the Alexander terrane: Journal of Geophysical Research, v. 97, no. B, p. 19641-19651.

Halgedahl, S.L., and Jarrard, R.D., 1987, Paleomagnetism of the Kuparuk River Formation from oriented drill core; evidence for rotation of the Arctic Alaska Plate, in Tailleur, I.L., and Weimer, Paul, eds., Alaskan North Slope geology: Los Angeles, Society of Economic Paleontologists and Mineralogists, Pacific Section, and Alaska Geological Society, v. 2, p. 581-620.

Hamilton, William, 1969, Mesozoic California and the underflow of Pacific mantle: Geological Society of America Bulletin, v. 80, p. 2409-2430.

Hansen, V.L., Goodge, J.W., Keep, M., and Oliver, D.H., 1993, Asymmetric rift interpretation of the western North American margin; Geology, v. 21, p. 1067-1070.

Hansen, V.L., Radloff, J.K., and Hart, C.J.R., 1990, Tally Ho shear zone, southern Yukon; kinematic evolution and tectonic implications [abs.]: Geological Association of Canada Annual Meeting Program with Abstracts, v. 15, p. 53-54.

Harbert, W., 1987, New paleomagnetic data from the Aleutian Islands; implication for terrane migration and deposition of the Zodiac Fan: Tectonics, v. 6, p. 585-602.

Harbert, W.P., Cox, A., and McLean, H., 1984, Paleomagnetism of Starr Point and Driftwood Bay, Umnak Island, Alaska [abs.]: Eos (American Geophysical Union Transactions), v. 65, p. 869.

Harbert, W., Frei, L., Jarrad, R., Halgedahl, S., and Engebretson, 
D.C., 1990, Paleomagnetic and plate-tectonic constraints on the evolution of the Alaska-eastern Siberian Arctic, in Grantz, Art, Johnson, L., and Sweeney, J.F., eds., The Arctic Ocean region (The Geology of North America, v. L): Boulder, Colo., Geological Society of America, p. 567-592.

Harms, T.A., 1986; Structural and tectonic analysis of the Sylvester Allochthon, southwest McDame map-area, northern British Columbia: implications for paleogeography and accretion: Tucson, University of Arizona, Ph.D. thesis, $114 \mathrm{p}$.

Harms, T.A., Nelson, J., and Bradford, J., 1988, Geological transect across the Sylvester allochthon, north of the Blue River, northern British Columbia, in Geological fieldwork, 1987: British Columbia Ministry of Energy, Mines, and Petroleum Resources Paper 1988-1, p. 245-248.

Harris, N.R., Sisson, V.B., Wright, J.E., and Pavlis, T.L., 1996, Evidence for Eocene mafic underplating during fore-arc intrusive activity, eastern Chugach Mountains, Alaska: Geology, v. 24, p. 263-266.

Harris, R.A., 1985, Paleomagnetism, geochronology and paleotemperature of the Yukon-Koyukuk province, Alaska: Fairbanks, University of Alaska, M.S. thesis, $145 \mathrm{p}$

Harris, R.A., Stone, D.B. and Turner, D.L., 1986, Tectonic implications of paleomagnetic and geochronologic data from the YukonKoyukuk province, Alaska: Geological Society of America Bulletin, v. 99, p. 362-375.

Hart, C.J.R., 1995, Sinistral translation of accreted terranes; yo-yo tectonics in the Canadian Cordillera [abs.]: Geological Association of Canada Annual Meeting Program with Abstracts, v. 20, p. 43.

Heiphitz, A., Harbert, W., and Layer, P., 1994b, Preliminary reconnaissance paleomagnetism of some late Mesozoic ophiolites, Kuyul region, Koryak superterrane, Russia, in Thurston, D., and Fujita, Kazuya, eds., Proceedings of 1994 International Conference on Arctic Margins: Anchorage, U.S. Minerals Management Service, p. 229-234.

Heiphitz, A., Harbert, W., and Savostin, L.A., 1994a, Reconnaissance paleomagnetism of the Olyutorsky superterrane, northeast Russia, in Thurston, D., and Fujita, Kazuya, eds., Proceedings of 1994 International Conference on Arctic Margins: Anchorage, U.S. Minerals Management Service, p. 223-228.

Heller, P.L., Tabor, R.W., O’Neil, J.R., Pevear, D.R., Shafiqullah, M., and Winslow, N., 1992, Isotopic provenance of Paleogene sandstones from the accretionary core of the Olympic Mountains, Washington: Geological Society of America Bulletin, v. 104, p. 140-153.

Hicken, A., and Irving, E., 1977, Tectonic rotation in western Canada: Nature, v. 268, p. 219-220.

Hillhouse, J.W., 1977, Paleomagnetism of the Triassic Nikolai Greenstone, McCarthy quadrangle, Alaska: Canadian Journal of Earth Science, v. 14, p. 2578-2592.

Hillhouse, J.W., and Grommé, C.S., 1982, Limits to northward drift of the Paleocene Cantwell formation, central Alaska: Geology, v. 10, p. 552-566.

-1984, Northward displacement and accretions of Wrangellia; new paleomagnetic evidence from Alaska: Journal of Geophysical Research, v. 89, no. B, p. 4461-4477.

1988, Early Cretaceous paleolatitude of the Yukon-Koyukuk province: Journal of Geophysical Research, v. 93, no. D, p. 11735-11752.

Hillhouse, G.W., Grommé, C.S., and Csejtey, Béla, Jr., 1984, Paleomagnetism of early Tertiary volcanic rocks in the northern Talkeetna Mountains, in Howell, D.G., Jones, D.L., Cox, A., and Nur, A., eds., Proceedings of the Circum-Pacific Terrane Confer- ence: Stanford University Publications in Geological Sciences, p. 111-114.

1985, Tectonic implications of paleomagnetic poles from Lower Tertiary volcanic rocks, south-central Alaska: Journal of Geophysical Research, v. 90, no. B, p. 12523-12535.

Himmelberg, G.R., Brew, D.A., and Ford, A.B., 1985, Ultramafic bodies in the Coast plutonic-metamorphic complex near Skagway, southeastern Alaska, in Bartsch-Winkler, Susan, ed., The United States Geological Survey in Alaska; accomplishments during 1984: U.S. Geological Survey Circular 967, p. 92-93.

Hoare, J.M., and Coonrad, W.L., 1978, Geologic map of the Goodnews and Hagemeister Island quadrangles region, southwestern Alaska: U.S. Geological Survey Open-File Report 78-9-B, scale $1: 250,000$.

1979, The Kanektok metamorphic complex, a rootless belt of Precambrian rocks in southwestern Alaska, in Johnson, K.M., and Williams, J.R., eds., The United States Geological Survey in Alaska; accomplishments during 1978: U.S. Geological Survey Circular 804-B, p. B72-B74.

Hoare, J.M., Conden, W.H., Cox, A., and Dalrymple, G.B., 1968, Geology, paleomagnetism and K-Ar ages of basalts from Nunivak Island, Alaska: Geological Society of America Memoir 116, p. 337-413.

Hoffman, P.F., 1989, Precambrian geology and tectonic history of North America, in Bally, A.W., and Palmer, A.R., eds., The geology of North America-an overview: Boulder, Colo., Geological Society of America, v. A, p. 447-512.

1991, Did the breakout of Laurentia turn Gondwanaland inside-out?: Science, v. 252, p. 1409-1412.

Hooper, P.R., 1982, The Columbia River Basalts: Science, v. 215, p. $1463-1468$.

Hooper, P.R., and Conrey, R.M., 1989, A model for the tectonic setting of the Columbia River Basalt eruptions, in Reidel, S.P., and Hooper, P.R., eds., Volcanism and tectonism in the Columbia River flood-basalt province: Geological Society of America Special Paper 239, p. 293-306.

Howell, D.G., Jones, D.L., and Schermer, E.R., 1985, Tectonostratigraphic terranes of the Circum-Pacific region: principles of terrane analysis, in Howell, D.G., ed., Tectonostratigraphic terranes of the Circum-Pacific region (Earth Science Series, v. 1): Houston, Tex., Circum-Pacific Council for Energy and Mineral Resources, p. 3-31.

Hudson, T., 1979, Mesozoic plutonic belts of southern Alaska: Geology, v. 7, p. 230-234.

Ichikawa, K., Mizutani, S., Hara, I., Hada, S., and Yao, A., eds., 1990, Pre-Cretaceous terranes of Japan in Pre-Jurassic Evolution of eastern Asia: Osaka, International Geologic Correlations Project Publication 224, $413 \mathrm{p}$.

Imaev, V.S., 1991, Late Cenozoic overthrusts, reverse faults, and folded dislocations of the Chersky seismic belt (eastern Yakutia): Geotectonics, v. 25, p. 356-361.

Imaev, V.S., Imaeva, L.P., and Koz'min, B.M., 1990, Active faults and seismotectonics of northeast Yakutia: Yakut Science Center, Yakutsk, 138 p. [in Russian].

Ingle, J.C., Karig, D.E., and Bouma, A.N., 1975, Leg 31: Deep Sea Drilling Project Initial Reports, v. 31, p. 351-439.

Iosifidi, A.G., 1989, Paleomagnetic directions and pole positions; data for the USSR-Soviet Geophysical Committee: Moscow, World Data Center-B, Catalog, no. 7, as quoted in Lock and McElhinny (1991).

Irving, E., and Archibald, D.A., 1990, Bathozonal tilt corrections to paleomagnetic data from mid-Cretaceous plutonic rocks; examples from the Omineca Belt, British Columbia: Journal of 
Geophysical Research, v. 95, no. B, p. 4579-4586.

Irving, E., and Brandon, M.T., 1990, Paleomagnetism of the Flores volcanics, Vancouver Island, in place by Eocene time: Canadian Journal of Earth Sciences, v. 27, p. 811-817.

Irving, E., and Irving, G.A., 1982, Apparent polar wander paths, Carboniferous through Cenozoic, and the assembly of Gondwana: Geophysical Surveys, v. 5, p. 141-188.

Irving, E., and Monger, J.W.H., 1987, Preliminary results from the Permian Asitka Group, British Columbia: Canadian Journal of Earth Sciences, v. 24, p. 1490-1497.

Irving, E., and Thorkelson, D.J., 1990, On determining paleohorizontal and latitudinal shifts; paleomagnetism of Spences Bridge Group, British Columbia: Journal of Geophysical Research, v. 95, no. B, p. 19213-19234.

Irving, E., Thorkelson, P.M., Wheadon, P.M., and Enkin, R.J., 1995, Paleomagnetism of the Spences Bridge Group and northward displacement of the Intermontane Belt, British Columbia; a second look: Journal of Geophysical Research, v. 100, no. B, p. 6075-6071.

Irving, E., Woodsworth, G.J., Wynne, P.J., and Morrison, A., 1985, Paleomagnetic evidence for displacement from the south of the Coast Plutonic Complex, British Columbia: Canadian Journal of Earth Sciences, v. 22, p. 584-598.

Irving, E., and Wynne, P.J., 1990, Paleomagnetic evidence bearing on the evolution of the Canadian Cordillera: Royal Philosophical Society of London Transactions, v. A331, p. 487-509. 1991, Paleomagnetism; review and tectonic implications, chap. 3 of Gabrielse, H., and Yorath, C.J., eds., Geology of the Cordilleran orogen, Canada (Geology of Canada, no. 4): Geological Survey of Canada, p. 63-86 [also Boulder, Colo., Geological Society of America, The Geology of North America, v. G-2, p. 63-86].

Irving, E., Wynne, P.J., Thorkelsen, D.J., and Schiarrizza, P., 1996, Large (1000 to $4000 \mathrm{~km}$ ) northward movements of tectonic domains in the Northern Cordillera, 83 to $34 \mathrm{Ma}$ : Journal of Geophysical Research, v. 101, no. B, p. 17901-17916.

Irving, E., and Yole, R.W., 1987, Tectonic rotations and translations in western Canada: new evidence from Jurassic rocks of Vancouver Island: Royal Astronomical Society Geophysical Journal, v. 91, p. 1025-1048.

Isacks, B., 1988, Uplift of the central Andean plateau and bending of the Bolivian orocline: Journal of Geophysical Research, v. 93, no. B, p. 3211-3231.

Ivanov, V.V., Klubev, B.A., Lozhkina, N.V., and Pokhialainen, V.P., 1977, Stratigraphy and paleomagnetic characteristics of the upper Jurassic and lower Cretaceous deposits of Stolbovoi Island (Novosibirskiy Archipelago): Geologiya i Geofizika, v. 18, p. 84-89.

Iwata, K., and Tajika, J., 1986, Late Cretaceous radiolarians of the Yubetsu Group, Tokoro Belt, northeast Hokkaido, Japan: Hokkaido University: Journal of the Faculty of Science: ser. 4, v. 21, p. 619-644.

Jarrad, R.D., 1986, Relations among subduction parameters: Reviews of Geophysics, v. 24, p. 217-284.

Jones, D.L., Coney, P.J., Harms, T.A., and Dillon, J.T., 1988, Interpretive geologic map and supporting radiolarian data from the Angayucham terrane, Coldfoot area, southern Brooks Range, Alaska: U.S. Geological Survey Miscellaneous Field Studies Map MF-1993, scale 1:63,360.

Jones, D.L., Howell, D.G., Coney, P.J., and Monger, J.W.H., 1983, Recognition, character, and analysis of tectonostratigraphic terranes in western North America, in Hashimoto, M., and Uyeda, S., eds., Accretion tectonics in the circum-Pacific region: proceedings of the Oji International Seminar on Accretion Tec- tonics, Japan, 1981: Tokyo, Terra Scientific Publishing Co., Advances in Earth and Planetary Sciences, p. 21-35.

Jones, D.L., Silberling, N.J., Berg, H.C., and Plafker, George, 1981, Map showing tectonostratigraphic terranes of Alaska, columnar sections, and summary description of terranes: U.S. Geological Survey Open-File Report 81-792, 20 p., 2 sheets, scale $1: 2,500,000$.

Jones, D.L., Silberling, N.J., Coney, P.J., and Plafker, George, 1984, Lithotectonic terrane map of Alaska, in Silberling, N.J., and Jones, D.L., eds., Lithotectonic terrane maps of the North American Cordillera: U.S. Geological Survey Open-File Report 84-523, p. A1-A12, scale 1:2,500,000.

Jones, D.L., Silberling, N.J., Coney, P.J., and Plafker, George, 1987, Lithotectonic terrane map of Alaska (west of the 141st Meridian): U.S. Geological Survey Miscellaneous Field Studies Map MF-1874-A, scale 1:2,500,000.

Jones, D.L., Silberling, N.J., and Hillhouse, J.W., 1977, Wrangellia-a displaced terrane in northwestern North America: Canadian Journal of Earth Sciences, v. 14, p. 2565-2577.

Journeay, J.M., and Friedman, R.M., 1993, The Coast Belt thrust system: evidence of Late Cretaceous shortening in southwest British Columbia: Tectonics, v. 12, p. 756-775.

Journeay, J.M., and Northcote, B.R., 1992, Tectonic assemblages of the eastern Coast Belt, southwest British Columbia, in Current research, part A: Geological Survey of Canada Paper 92-1A, p. $215-224$.

Kanygin, A.V., 1967, Ordovician ostracodes from the Chersky Range: Moscow, Nauka, 152 p. [in Russian].

-1977, Ordovician ostracodes of Chukotka Peninsula: Stratigraphy and fauna of the Ordovician and Silurian in Chukotka peninsula: Novosibirsk, Nauka, p. 73-86 [in Russian].

Karl, S., and Hoare, J.M., 1979, Results of a preliminary paleomagnetic study of volcanic rocks from Nuyakuk Lake, southwestern Alaska, in Johnson, K.M., and Williams, J.R., The United States Geological Survey in Alaska; accomplishments in 1978: U.S. Geological Survey Circular 804-B, p. B74-B78.

Karlstrom, K.E., Williams, M.L., McLelland, J., Geissman, J.W., and Ahall, K., 1999, Refining Rodinia; geologic evidence for the Australia-Western U.S. connection in the Proterozoic: GSA Today, v. 9, p. 1-7.

Kashik, D.S., Ganelin, V.G., Karavaeva, N.I., Byakov, A.S., MiclukhhoMaclay, O.A., Stukalina, G.A., Lozhkina, N.V., Dorofeeva, L.A., Burkov, J.K., Guteneva, E.I., and Smirnova, L.N., 1990, A key Permian section of the Omolon massif: Leningrad, Nauka, p. 198.

Kato, T., and Nakagawa, M., 1986, Tectogenesis of ultramafic rocks in the Kamuikotan tectonic belt, Hokkaido, Japan: Osaka, Association for Geological Collaboration in Japan Monograph 31, p. 119-135 [in Japanese with English abstract].

Kazimirov, A.D., 1985, Nappes of the eastern Koryak Highland and their structural and formational homologues: Moscow, Nauka, 112 p. [in Russian].

Keith, T.E., Foster, H.L., Foster, R.L., Post, E.V., and Lehmbeck, W.L., 1981, Geology of an alpine-type peridotite in the Mount Sorenson area, east-central Alaska: U.S. Geological Survey Professional Paper 1170-A, 9 p.

Kepezhinskas, P.K., Reuber, I., Tanaka, H., and Miyashita, S., 1993, Zoned calc-alkaline plutons in northeastern Kamchatka, Russia; implications for the crustal growth in magmatic arcs: Mineralogy and Petrology, v. 49, p. 147-174.

Khanchuk, A.I., 1993, Geologic setting and evolution of the northwest Pacific continental framework: Moscow, Russian Academy of Sciences, Geological Institute, summary of Ph.D. thesis, 31 p. [in Russian]. 
Khanchuk, A.I., Golozubov, V.V., Panchenko, I.V., Ignatiev, A.V., and Chudaev, O.V., 1992, Ganychalan terrane of the Koryak Highland: Pacific Geology, no. 4, p. 84-93.

Khanchuk, A.I., Grigorev, V.I., Golozubov, V.V., Govorov, G.I., Krylov, K.A., Kurnosov, V.I., Panchenko, I.V., Prainikova, I.E., and Chudaev, O.V., 1990, Kuyul Ophiolite terrane: Vladivostok, Russian Academy of Sciences, Far East Branch, 108 p. [in Russian].

Khanchuk, A.I., Ognyanov, A.V., Popova, I.M., and Philippov, A.N., 1994, New data on Early Cretaceous deposits of the Lower Priamurye: Rossiiskoi Academii Nauk Doklady, v. 338, no. 5, p. 667-671 [in Russian].

Khanchuk, A.I., Panchenko, I.V., and Kemkin, I.V., 1988, Paleozoic and Mesozoic geodynamic evolution of the Sikhote Alin area and Sakhalin Island: U.S.S.R. Academy of Sciences, Vladivostok, 56 p. [in Russian].

Khanchuk, A.I., Ratkin, V.V., Ryazantseva, M.D., Golozubov, V.V., and Gonokhova, N.B., 1996, Geology and mineral deposits of Primorsky Krai (territory): Vladivostok, Russian Academy of Sciences, Geological Institute, Far East Branch, Dalnauka, 61 p.

Khramov, A.N., 1971, Paleomagnetic directions and pole positions; data for the USSR: Moscow, Soviet Geophysical Committee, World Data Center-B, no. 1, as quoted in Lock and McElhinny (1991).

1979, Paleomagnetic directions and pole positions; data for the USSR: Moscow, Soviet Geophysical Committee, World Data Center-B, no. 4, as quoted in Lock and McElhinny (1991). 1984, Paleomagnetic directions and pole positions: data for the USSR: Moscow, Soviet Geophysical Committee, World Data Center-B, no. 1, 94 p. [in Russian].

-1986a, Paleomagnetic directions and pole positions: data for the USSR: Soviet Geophysical Committee: Moscow, World Data Center-B, no. 6, as quoted in Lock and McElhinny (1991). ed., 1986b, Paleomagnetic directions and pole positions. data for the USSR: Moscow, Soviet Geophysical Committee World Data Center-B, no. 6, 38 p. [in Russian].

Khramov, A.N., Gurevich, E.L,. Komissarova, R.A., Osipova, E.P., Pisarevsky, S.A., Rodioniv, V.P., and Slautsitais, I.P., 1985, Paleomagnetism, microplates, and Siberian plate consolidation: Journal of Geodynamics, v. 2, p. 127-139.

Khubunaya, S.A., 1981, Nature of basalt of the Kronotskiy Peninsula (eastern Kamchatka): Vulkanologiya i Seismologiya, no. 2, p. 36-48 [in Russian].

Khudoley, A.K., and Sokolov, S.D., 1998, Structural evolution of the northeast Asian continental margin: an example from the western Koryak fold and thrust belt (northeast Russia): Geological Magazine, v. 135, p. 311-330.

Kiminami, K., and Kontani, Y., 1983, Mesozoic arc trench system in Hokkaido, Japan, in Hashimoto, M., and Uyeda, S., eds., Accretion tectonics in Circum-Pacific regions: Tokyo, Terra Educational Publishing Co., p. 107-122.

Kimura, G., and Tamaki, K., 1986, Collision, rotation and back-arc spreading; the case of the Okhotsk and Japan Seas: Tectonics, v. 5, p. 389-401.

Kirillova, G.L., and Makhinin, A.V., 1983, Classification of geologic objects and organization of matter: Tikhookeanskaya Geologiya, no. 3, p. 73-80 [in Russian].

Kirillova, G.L., and Turbin, M.T., 1979, Formations and tectonics of the Dzhagdinsk Zone of the Mongol-Okhotsk foldbelt: Moscow, Nauka, 114 p. [in Russian].

Klepacki, D.W., 1983, Stratigraphic and structural relations of the Milford, Kaslo, and Slocan groups, Roseberry Quadrangle, Lardeau map-area, British Columbia, in Current research, part A: Geological Survey of Canada Paper 83-1-A, p. 229-233.
Kojima, S., 1989, Mesozoic terrane accretion in northeastern China, Sikhote Alin, and Japan regions: Palaeogeography, Palaeoclimatology, and Palaeoecology, v. 69, p. 213-232.

Kojima, S., Wakita, Koji, Okamura, Y., Natal'in, B.A., Zyabrev, S.V., Zhang, Q.L., and Shao, J.A., 1991, Mesozoic radiolarians from the Khabarovsk complex, eastern USSR; their significance in relation to Mino terrane, central Japan: Journal of Geological Society of Japan, v. 97, p. 549-551.

Kolosev, E.V., 1981, Paleomagnetic characteristics of Middle Paleozoic sediments of the Omolon massif: magnetism of rocks and paleomagnetic stratigraphy in Eastern and Northeastern Asia: Soviet Academy of Sciences, Northeast Integrated Scientific Research Institute, Magadan, p. 68-74.

Konstantinovskaya, E.A., Geodynamics of island arc-continent collision in the western Pacific margin: Geotectonics, v. 33, p. 15-34.

Korol'kov, V.G., and Korol'kova, A.M., 1974, Notes on the stratigraphy of Permian deposits of the Okhotsk median massif. [abs.]: Precambrian and Paleozoic of northeast USSR, Abstracts of papers submitted to the Interdepartmental Stratigraphic Meeting, USSR Interdepartmental Committee on Stratigraphy, Magadan, p. 135-134 [in Russian].

Kos'ko, M.K., Sobolevskaya, R.F., Nepomiluev, V.F., and Volnov, D.A., 1974, Lower to Middle Paleozoic of the New Siberian Islands [abs.]: Precambrian and Paleozoic of northeast USSR, Abstracts of Papers submitted to the Interdepartmental Stratigraphic Meeting, USSR Interdepartmental Committee on Stratigraphy, Magadan, p. 163-167 [in Russian].

Kotlyar, I.N., 1997, Petrological modeling at the prognostication and estimation of gold-silver mineralization in poorly-developed mining regions, in Byalobzhesky, S.G., ed., Magmatism and ore mineralization of Northeast Russia: Northeast Integrated Scientific Research Institute (NEISRI), Russian Academy of Sciences, Magadan, p. 34-56.

Kovalenko, D.V., 1992, Geology and paleomagnetism of the northwest framework of the Bering Sea region: Geotectonics, v. 29, p. 78-95 [in Russian].

1996, Paleomagnetism and kinematics of the central Olyutorsky Range, Koryak Highland: Geotectonics, v. 30, p. 243-257 [in Russian].

Kovalenko, D.V., and Remizova, L.L., 1997, Paleomagnetism of the northwestern Olyotorskii Zone, southern Koryak Upland: Physics of the Solid Earth Izvestiya, v. 33, p. 589-598.

Kosygin, Yu.A., ed., 1985, Tectonic map of oil and gas areas of the Far East and adjacent territories: U.S.S.R. Academy of Sciences, Institute of Tectonics and Geophysics, Far Eastern Branch, Khabarovsk, 9 sheets, scale 1:2,500,000 [in Russian].

Kozlovsky, E.A., ed., 1988, Geology of the BAM Zone, geological structure: Nedra, Leningrad, 443 p. [in Russian].

Koz'min, B.M., 1984, Seismic belts of Yakutia and the mechanisms of their earthquakes: Moscow, Nauka, 125 p. [in Russian].

Koz'min, B.M., Imaev, V.S., Imaeva, L.P., Fujita, Kazuya, Chung, W.Y., and Gao, H., 1996, Seismicity and active faults of the eastern Siberian platform [abs.]: Eos (American Geophysical Union Transactions), v. 15, p. F521.

Krasny, L.I., ed., 1966, Geological description of the Khabarovsk Territory and Amur Region (Geology of the U.S.S.R., v. 19): Nedra, Moscow, 736 p. [in Russian].

Kusky, T.M., and Bradley, D.C., 1999, Kinematic analysis of melange fabrics; examples and applications from the McHugh Complex, Kenai Peninsula, Alaska: Journal of Structural Geology, v. 21, p. 1773-1796.

Kusky, T.M., Bradley, D.C., and Haeussler, P., 1997, Progressive defor- 
mation of the Chugach accretionary complex, Alaska, during a Paleogene ridge-trench encounter: Journal of Structural Geology, v. 19, p. 139-157.

Kusky, T.M., Bradley, D.C., Haeussler, P.J., and Karl, S., 1997, Controls on accretion of flysch and melange belts at convergent margins; evidence from the Chugach Bay thrust and Iceworm melange, Chugach accretionary wedge, Alaska: Tectonics, v. 16 , p. 855-878.

Kusky, T.M., and Young, C.P., in press, Emplacement of the Resurrection Peninsula ophiolite in the southern Alaska forearc during a ridge-trench encounter: Journal of Geophysical Research.

Lane, L.S., 1994, A new plate kinematic model of Canada Basin evolution, in Thurston, D., and Fujita, Kazuya, eds., Proceedings of 1994 International Conference on Arctic Margins: Anchorage, U.S. Minerals Management Service, p. 283-288.

1997, Canada Basin, Arctic Ocean; evidence against a rotational origin: Tectonics, v. 16, p. 363-387.

Larson, K.M., Freymueller, J.T., and Philipsen, S., 1997, Global plate velocities from the Global Positioning System: Journal of Geophysical Research, v. 102, no. B, p. 9961-9981.

Lassiter, J.C., DePaolo, D.J., and Mahoney, J.J., 1994, Geochemistry of the Wrangellia flood basalt province: Implications for the role of continental and oceanic lithosphere in flood basalt genesis: Journal of Petrology, v. 36, p. 983-1010.

Latin, D., and White, N., 1990, Generating melt during lithospheric extension; pure shear vs. simple shear: Geology, v. 18, p. 7-31.

Lawver, L.A., and Scotese, C.R., 1990, A review of tectonic models for the evolution of the Canada Basin, chap. 31 of Grantz, Art, Johnson, L., and Sweeny, J.F., eds., The Arctic Ocean region (The Geology of North America, v. L): Boulder, Colo., Geological Society of America, p. 593-618.

Layer, P.W., Parfenov, L.M., Trunilina, V.A., and Bakharev, A.G., 1995, Age and tectonic significance of granitic belts within the Verkhoyansk fold and thrust belt, Yakutia, Russia [abs.]: Geological Society of America Abstracts with Programs, v. 27, p. 60.

Lebedev, E.L., Gur'yanov, V.A., Rasskazov, Yu.P., and Chepygin, V.E., 1989, Geologic development and volcanism of the southern part of the Okhotsk-Chukotka volcanic belt: Tikhookeanskaya Geologiya, no. 8, p. 50-55 [in Russian].

Lee, D.S., 1987, Geology of Korea: Seoul, Geological Society of Korea, Kyohak S.A. Publications, $514 \mathrm{p}$.

Litvinov, V.E., and Umitbaev, R.B., 1974, Stratigraphy of Upper Paleozoic deposits of the Okhotsk massif and southern Yana Kolyma geosyncline system [abs.]: Precambrian and Paleozoic of northeast USSR. Abstracts of papers submitted to the Interdepartmental stratigraphic Meeting, USSR Interdepartmental Committee on Stratigraphy, Magadan, p. 136-138 [in Russian].

Lock, J., and McElhinny, M.W., 1991, The global paleomagnetic data base: Dordrecht, Holland, Kluwer Academic Publishers, $491 \mathrm{p}$.

Lomtev, V.L., and Patrikeev, V.N., 1965, Pressure structures in the Kuril and Japan trenches: Vladivostok, U.S.S.R. Academy of Sciences, Far Eastern Branch, 147 p. [in Russian].

Lonsdale, P., 1988, Paleogene history of the Kula plate; offshore evidence and onshore implications: Geological Society of America Bulletin, v. 100, p. 755-766.

Lund, Karen, and Snee, L.W., 1988, Metamorphism, structural development, and age of the continent-island-arc juncture in westcentral Idaho, in Ernst, W.G., ed., Metamorphism and crustal evolution, western conterminous United States (Rubey volume 7): Boulder, Colo., Geological Society of America, p. 296-337.

Lychagin, P.P., 1978, Middle Paleozoic magmatism of the Omolon massif: Magadan, U.S.S.R. Academy of Sciences, 195 p. [in Russian].
Lychagin, P.P., Byalobzhesky, S.G., Kolyasnikov, Yu.A., Korago, E.A., and Likman, V.B., 1991, Geology and petrography of the Gromandensko-Vuruveemskiy gabbro-norite massif, South Anyui folded zone: Magadan, U.S.S.R. Academy of Sciences, 45 p. [in Russian].

Lychagin, P.P., Dylevsky, E.F., Shpikerman, V.I., and Likman, B.V., 1989, Magmatism of the central region of the northeastern U.S.S.R.: U.S.S.R. Academy of Sciences, Vladivostok, 120 p. [in Russian]

Lytwyn, J., Casey, J., and Gilbert, S., 1997, Arc-like mid-ocean ridge basalt formed seaward of a trench-forearc system just prior to ridge subduction: an example from subaccreted ophiolites in southern Alaska: Journal of Geophysical Research, v. 102, no. B5, p. 10225-10242.

Mackey, K.G., Fujita, Kazuya, Gunbina, L.V., Kovalev, V.N., Imaev, V.S., Koz'min, B.M., and Imaeva, L.P., 1997, Seismicity of the Bering Strait region; evidence for a Bering block: Geology, v. 25, p. 979-982.

Maeda, J., 1990, Opening of the Kuril Basin deduced from the magmatic history of central Hokkaido, north Japan: Tectonophysics, v. 174, p. 235-255 [in Russian].

Mahoney, J.B., and Journeay, J.M., 1993, The Cayoosh assemblage, southwestern British Columbia; last vestige of the Bridge River Ocean, in Current research, part A: Geological Survey of Canada Paper 93-1A, p. 235-244.

Maiboroda, A.A., and Sharueva, L.I., 1979, Composition of Jurassic deposits in the western part of the Ulbansk basin, Primorye, in sedimentary and volcanosedimentary formations of the Far East: Vladivostok, U.S.S.R. Academy of Science, p. 27-36 [in Russian].

Marquis, G., and Globerman, B.R., 1987, Northward motion of the Whitehorse Trough, paleomagnetic evidence from the Upper Cretaceous Carmacks Group: Canadian Journal of Earth Sciences, v. 25, p. 2005-2016.

Martynov, Yu.A., 1994, The importance of $\mathrm{Al}_{2} \mathrm{O}_{3}$ for systematic chemistry of basaltic rocks: Tikhookeanskaya Geologiya, no. 2, p. 94-99 [in Russian].

Martynov, Yu.A., and Okamura, S., 1993, Variation of Sr and $\mathrm{Nd}$ isotopic ratios in Paleocene-Pleistocene basalts of the East Sikhote-Alin: Akademii Nauk SSR Izvestiya, Seriya Geologicheskaya, no. 333, p. 366-369 [in Russian].

Maxson, J.A., Kleinspehn, K.L., Wynne, P.J., and Irving, E., 1993, Paleomagnetic evidence for northward displacement of western British Columbia from the mid-Cretaceous Silverquick fluvial deposits and Powell Creek volcanics, northern Tyaughton Basin [abs.]: Geological Society of America Abstracts with Programs, v. 25, p. 116

McCaffrey, R., and Abers, G.A., 1991, Orogeny in arc-continent collision; the Banda arc and western New Guinea: Geology, v. 19, p. 563-566.

McClelland, W.C., 1992, Permian and older rocks of the southwestern Iskut River map area, northwestern British Columbia, in Current research, part A: Geological Survey of Canada Paper 92-1A, p. 303-307.

_1997, Detrital zircon studies of the Proterozoic Neruokpuk Formation, Sadlerochit and Franklin Mountains, northeastern Alaska [abs.]: Geological Society of America Abstracts with Programs, v. 29, p. 28.

McClelland, W.C., Gehrels, G.E., and Saleeby, J.B., 1992a, Upper Jurassic-Lower Cretaceous basinal strata along the Cordilleran margin; implications for the accretionary history of the Alexander-Wrangellia-Peninsular terrane: Tectonics, v. 11, p. 832-835.

McClelland, W.C., Gehrels, G.E., Samson, S.D., and Patchett, P.J., 
1991, Protolith relations of the Gravina belt and Yukon-Tanana terrane in central southeastern Alaska: Journal of Geology, v. 100, p. 107-123.

-1992b, Structural and geochronologic relations along the western flank of the Coast Mountains batholith; Stikine River to Cape Fanshaw, central southeastern Alaska: Journal of Structural Geology, v. 14, p. 475-489.

May, S.R., Beck, M.E., Jr., and Butler, R.F., 1989, North American apparent polar wander, plate motion, and left-oblique convergence, Late Jurassic-Early Cretaceous orogenic consequences: Tectonics, v. 8, p. 433-541.

Mihalynuk, M.G., Nelson, J., and Diakow, L.J., 1994, Cache Creek terrane entrapment: oroclinal paradox within the Canadian Cordillera: Tectonics, v. 13, p. 575-595.

Mikhailov, V.A., Vrublevsky, A.A., and Yushmanov, Yu.P., 1987, Structure and conditions of nappe structure formation in the Pribrezhnaya zone (Primorie): Tikhookeanskaya Geologiya, no. 1, p. 83-91.

Mikhailov, V.A., Volokhin, Yu.G., Parnyakov, V.P., and Oleinik, L.M., 1989, Age and nature of the Gorbushinsk series, Pribrezhnaya zone in the Sikhote-Alin fold belt: Tikhookeanskaya Geologiya, no. 4, p. 70-77 [in Russian].

Mikhailov, V.A., Volokhin, Yu.G., Parnyakov, V.P., Oleinik, L.M., and Buryi, G.I., 1986, Gorbusha series of Dalnegorsk area, in Zakharov, Y.D., Belyaeva, G.V., and Nikitina, A.P., eds., New data on the Paleozoic and Mesozoic biostratigraphy of the southern Russian Far East: Vladivostok, U.S.S.R. Academy of Sciences, p. 28-36 [in Russian].

Miller, E.L., and Hudson, T.L., 1991, Mid-Cretaceous extensional fragmentation of a Jurassic-Early Cretaceous compressional orogen, Alaska: Tectonics, v. 10, p. 781-796.

Miller, M.L., Bradshaw, J.Y., Kimbrough, D.L., Stern, T.W., and Bundtzen, T.K., 1991, Isotopic evidence for early Proterozoic age of the Idono Complex, west-central Alaska: Journal of Geology, v. 99, p. 209-223.

Miller, M.L., and Bundtzen, T.K., 1993, Geologic map of the Iditarod quadrangle showing K-Ar, major oxide, trace element, fossil, paleocurrent, and archeological sample localities: U.S. Geological Survey Map MF-2219, scale 1:250,000.

Miller, T.P., 1989, Contrasting plutonic rock suites of the Yukon-Koyukuk basin and the Ruby geanticline, Alaska: Journal of Geophysical Research, v. 94, no. B, p. 15969-15989.

1994, Pre-Cenozoic plutonic rocks in mainland Alaska, in Plafker, George, and Berg, H.C., eds., The geology of Alaska (The Geology of North America, v. G-1): Boulder, Colo., Geological Society of America, p. 535-554.

Miller, T.P., and Richter, D.H., 1994, Quaternary volcanism in the Alaska Peninsula and Wrangell Mountains, Alaska, in Plafker, George, and Berg, H.C., eds., The geology of Alaska (The Geology of North America, v. G-1): Boulder, Colo., Geological Society of America, p. 759-780.

Minoura, K., 1990, The pre-Cretaceous geology and tectonics of northern Kitakami region, in Pre-Cretaceous terranes of Japan: Osaka, International Geologic Correlations Project Report 224, p. 267-279.

Mizutani, S., 1987, Mesozoic terranes in the Japanese Islands and neighboring East Asia, in Leitch, E.C., and Scheibner, E., eds., Terrane accretion and orogenic belts (Geodynamic Series, v. 19): Washington, D.C., American Geophysical Union, p. 263-273.

1990, Mino terrane, in Pre-Cretaceous terranes of Japan: Osaka, International Geologic Correlations Project Report 224, p. 121-135.
Mizutani, S., and Kojima, S., 1992, Mesozoic radiolarian biostratigraphy of Japan and collage tectonics along the eastern continental margin of Asia: Palaeogeography, Palaeoclimatology, and Palaeoecology, v. 96, p. 3-32.

Moll-Stalcup, E.J., 1990, Latest Cretaceous and Cenozoic magmatism in mainland Alaska: U.S. Geological Survey Open-File Report 90-84, $80 \mathrm{p}$.

1994, Latest Cretaceous and Cenozoic magmatism in mainland Alaska, in Plafker, George, and Berg, H.C., eds., The geology of Alaska (The Geology of North America, v. G-1): Boulder, Colo., Geological Society of America, p. 589-620.

Moll-Stalcup, E.J., Brew, D.A., and Vallier, T.L., 1994, Map of latest Cretaceous and Cenozoic igneous rocks of Alaska, pl. 5 of Plafker, George, and Berg, H.C., eds., The geology of Alaska (The Geology of North America, v. G-1): Boulder, Colo., Geological Society of America, scale 1:2,500,000.

Monger, J.W.H., 1977, Upper Paleozoic rocks of the western Canadian Cordillera and their bearing on Cordilleran evolution: Canadian Journal of Earth Sciences, v. 14, p. 1832-1859. 1985, Structural evolution of the southwestern Intermontane Belt, Ashcroft and Hope map areas, British Columbia, in Current research, part A: Geological Survey of Canada Paper 85-1A, p. 349-358.

1989, Geology of Hope and Ashcroft map-areas: Geological Survey of Canada Maps 41-1989, 42-1989, scale 1:250,000. 1991, Late Mesozoic to Recent evolution of the Georgia StraitPuget Sound region, British Columbia and Washington: Washington Geology, v. 19, no. 4, p. 3-7.

1993, Cretaceous tectonics of the North American Cordillera, in Caldwell, W.G.E., and Kauffman, E.G., eds., Evolution of the western interior basin: Geological Association of Canada Special Paper 39, p. 31-47.

1997, Plate tectonics and northern Cordilleran geology; an unfinished revolution: Geoscience Canada, v. 24, p. 189-198.

Monger, J.W.H., and Berg, H.C., 1987, Lithotectonic terrane map of western Canada and southeastern Alaska: U.S. Geological Survey Miscellaneous Field Studies Map MF-1874-B, 12 p., scale 1:2,500,000.

Monger, J.W.H., Clowes, R.M., Price, R.A., Simony, P.S., Riddihough, R.P., and Woodsworth, G.J., 1985, Juan de Fuca to Alberta, Canada: Geological Society of America Centennial Continent/ Ocean Transect 7, 2 sheets, scale 1:500,000.

Monger, J.W.H., and Irving, E., 1980, Northward displacement of north-central British Columbia: Nature, v. 285, p. 289-294.

Monger, J.W.H., and Journeay, J.M., 1994, Basement geology and tectonic evolution of the Vancouver region, in Geology and geological hazards of the Vancouver region, southwestern British Columbia: Geological Survey of Canada Bulletin 481, p. 3-25.

Monger, J.W.H., and Nokleberg, W.J., 1996, Evolution of the northern North American Cordillera; generation, fragmentation, displacement, and accretion of successive North American plate margin arcs, in Coyner, A.R., and Fahey, P.L., eds., Geology and ore deposits of the American Cordillera: Geological Society of Nevada Symposium, Reno/Sparks, Nev., 1995, Proceedings, p. 1133-1152.

Monger, J.W.H., Nokleberg, W.J., Dawson, K.M., Parfenov, L.M., Bundtzen, T.M., and Shpikerman, V.I., 1996, Tectonic settings of Paleozoic through Cretaceous mineral deposits of the Canadian Cordillera and Alaska, with extensions into the Russian Northeast [abs.]: 1996 Canadian Cordilleran Roundup Program with Abstracts, p. 27-28.

Monger, J.W.H., Price, R.A., and Tempelman-Kluit, D.J., 1982, Tectonic 
accretion and the origin of the two major metamorphic and plutonic welts in the Canadian Cordillera: Geology, v. 10, p. 70-75.

Monger, J.W.H., Price, R.A., Wynne, P.J., Thorkelson, D.J., Kleinspehn, K.L., Maxson, J.A., and Irving, E., 1996, Paleomagnetism of the Upper Cretaceous strata of Mount Tatlow; evidence for $3000 \mathrm{~km}$ of northward displacement of the eastern Coast Belt, British Columbia, and Paleomagnetism of the Spences Bridge Group and northward displacement of the Intermontane Belt, British Columbia; a second look; discussion and reply: Journal of Geophysical Research, v. 101, no. B, p. 13793-13803.

Monger, J.W.H., and Ross, C.A., 1971, Distribution of fusulinaceans in the Canadian Cordillera: Canadian Journal of Earth Sciences, v. 8, p. 770-791.

Monger, J.W.H., Souther, J.G., and Gabrielse, H., 1972, Evolution of the Canadian Cordillera; a plate tectonic model: American Journal of Science, v. 272, p. 577-602.

Monger, J.W.H., van der Heyden, P., Journeay, J.M., Evenchick, C.A., and Mahoney, J.B., 1994, Jurassic-Cretaceous basins along the Canadian Cordillera; their bearing on pre-mid-Cretaceous sinistral displacements: Geology, v. 22, p. 175-178.

Monger, J.W.H., Wheeler, J.O., Tipper, H.W., Gabrielse, H., Harms, T., Struik, L.C., Campbell, R.B., Dodds, C.J., Gehrels, G.E., and O'Brien, J., 1991, Cordilleran terranes, in Gabrielse, H., and Yorach, C.J., eds., Geology of the Cordilleran orogen, Canada: Geological Survey of Canada, Geology of Canada, no. 4, p. 281-327 [also Boulder, Colo., Geological Society of America, The Geology of North America, v. G-2, p. 281-327].

Moore, J.C., Byrne, T., Plumley, P.W., Reid, M., Gibbons, H., and Coe, R.S., 1983, Paleogene evolution of the Kodiak Islands, Alaska; consequences of ridge-trench interaction in a more southerly latitude: Tectonics, v. 2, p. 265-293.

Moore, T.E., Grantz, Art, and Roeske, S.M., 1994a, Continent-ocean transition in Alaska; the tectonic assembly of eastern Denalia, in Speed, R.C., ed., Phanerozoic evolution of North American continent-ocean transitions (Continent-Ocean Transect Volume): Boulder, Colo., Geological Society of America, p. 399-441.

Moore, T.E., Wallace, W.K., Bird, K.J., Karl, S.M., Mull, C.G., and Dillon, J.T., 1994b, Geology of northern Alaska, in Plafker, George, and Berg, H.C., eds., The geology of Alaska (The Geology of North America, v. G-1): Boulder, Colo., Geological Society of America, p. 49-140.

Moores, E.M., 1991, Southwest U.S.-East Antarctic (SWEAT) connection; a hypothesis: Geology, v. 19, p. 425-428.

Mortensen, J.K., 1992, Pre-mid-Mesozoic tectonic evolution of the Yukon-Tanana terrane, Yukon and Alaska: Tectonics, v. 11, p. 836-853.

Mortimer, N. 1987, The Nicola Group; Late Triassic and Early Jurassic subduction-related volcanism in British Columbia: Canadian Journal of Earth Sciences, v. 24, p. 2521-2536.

Muller, J.E., 1977, Evolution of the Pacific Margin, Vancouver Island and adjacent regions: Canadian Journal of Earth Sciences, v. 14, p. 2062-2085.

1980, The Paleozoic Sicker Group of Vancouver Island, British Columbia: Geological Survey of Canada Paper 79-30, 24 p.

Nakamura, E., McCulloch, M.T., and Campbell, I.H., 1990, Chemical geodynamics in the back-arc region of Japan based on the trace-element and $\mathrm{Sr}-\mathrm{Nb}$ isotopic compositions: Tectonophysics, v. 174, p. 207-283.

Natal'in, B.A., 1984, Early Mesozoic eugeosynclinal systems in the northern part of the Circum-Pacific: Moscow, Nauka, 136 p. [in Russian].
1991, Mesozoic accretionary and collisional tectonics of the southern Far East: Tikhookeanskaya Geologiya, no. 5 [in Russian].

1993, History and mode of Mesozoic accretion in southeastern Russia: Island Arc, v. 2, p. 32-48.

Natal'in, B.A., and Alexeenko, S.N., 1989, Tectonics of the Sredneamursk basin basement: Vladivostok, U.S.S.R. Academy of Sciences, Far East Branch, $57 \mathrm{p}$.

Natal'in, B.A., and Borukayev, Ch.B., 1991, Mesozoic sutures in the Far East South: Geotectonics, v. 1, p. 84-96.

Natal'in, B.A., and Faure, M., 1991, Geodynamics of the Asia eastern margin in the Mesozoic: Tikhookeanskaya Geologiya, v. 6, p. 3-23.

Natal'in, B.A., Parfenov, L.M., Vrublevsky, A.A., Karsakov, L.P., and Yushmanov, V.V., 1986, Main fault systems of the Soviet Far East: Philosophical Transactions of the Royal Society of London, v. 317, p. 267-275.

Natal'in, B.A., and Popeko, L.I., 1991, The Paleozoic of the Galamsk segment of the Mongol-Okhotsk fold belt: Tikhookeanskaya Geologiya, no. 2, p. 81-89 [in Russian].

Natal'in, B.A., Popeko, L.I., and Chobotov, S.A., 1985, Tectonics of the West Dzhagdinsk zone of the Mongol-Okhotsk fold belt: Tikhookeanskaya Geologiya, no. 2, p. 49-64 [in Russian].

Natal'in, B.A., and Zyabrev, S.V., 1989, Structure of Mesozoic rocks of the Amur river valley: International Symposium on Tectonics, Energy and Mineral Resources of Northwest Pacific, Khabarovsk, 1989, Field Trip Guide-Book, 48 p.

Natapov, L.M., ed., 1984, Geologic map of the U.S.S.R: Leningrad, U.S.S.R. Ministry of Geology, 128 p., scale 1:1,000,000 [in Russian].

Natapov, L.M., and Shuligina, W.S., eds., 1991, Geologic map of the U.S.S.R.: Leningrad, U.S.S.R. Ministry of Geology, 111 p., scale 1:1,000,000 [in Russian].

Natapov, L.M., and Surmilova, E.P., eds., 1986, Geological map of the U.S.S.R.: Leningrad, U.S.S.R. Ministry of Geology, 120 p., scale $1: 1,000,000$ [in Russian].

Nazarenko, L.F., and Bazhanov, V.A., 1986, Geology of the Primorsk Territory: Vladivostok, U.S.S.R. Academy of Sciences, Far East Branch, 154 p. [in Russian].

Nechaev, V.P., Markevich, P.V., Malinovsky, A.I., Philippov, A.N., and Vysotsky, S.V., 1996, Tectonic setting of the Cretaceous sediments in the Lower Amur Region, Russian Far East: Sedimentary Society of Japan Journal, v. 43, p. 69-81.

Nekrasov, G.E., 1976, Tectonics and magmatism of Taigonos and northwestern Kamchatka: Moscow, Nauka, 158 p. [in Russian].

Nekrasov, G.E., and Sumin, L.V., 1987, Melanocratic basement of the Pekul'ney Range and its $\mathrm{Pb} / \mathrm{Pb}$ thermoisochron age, in Essays on the geology of northwestern sector of the Pacific tectonic belt: Moscow, Nauka, p. 183-199 [in Russian].

Nelson, J.L., 1993, The Sylvester allochthon: upper Paleozoic marginal-basin and island-arc terranes in northern British Columbia: Canadian Journal of Earth Sciences, v. 30, p. 631-643.

Nelson, J.L., and Bradford, J.A., 1989, Geology and mineral deposits of the Cassiar and McDame areas, British Columbia, in Geological fieldwork 1988: British Columbia Ministry of Energy, Mines and Petroleum Resources Paper 1989-1, p. 323-338.

Nelson, J.L., and Mihalynuk, M., 1993, The Cache Creek ocean; closure or enclosure?: Geology, v. 21, p. 173-176.

Nelson, S.W., 1992, Ophiolitic complexes in the Gulf of Alaska: U.S. Geological Survey Open-File Report 92-20-C, $10 \mathrm{p}$.

Nelson, S.W., Dumoulin, J.A., and Miller, M.L., 1985, Geologic map of the Chugach National Forest, Alaska: U.S. Geological Survey Miscellaneous Field Studies Map MF-1645-B, 16 p., scale 1:250,000. 
Neustroev, A., Parfenov, L.M., and Rodionov, V.P., 1993, Paleomagnetic data and the nature of the Tas-Khayakhtakh terrane in the Verkhoyansk-Kolyma region: Geologiya i Geofizika, v. 8, p. 25-37 [in Russian].

Nevolina, S.I., and Sokarev, A.N., 1986, Paleomagnetic directions and pole positions; data for the USSR-Soviet Geophysical Committee: Moscow, World Data Center-B, Catalog, no. 6, as quoted in Lock and McElhinny (1991).

Nikolaev, A.A., Oradovskaya, M.M., Preobrazhensky, B.V., Obut, A.M., Sobolevskaya, R.F., and Kabanov, V.Ya., 1974, A reference cross-section of the Ordovician in northeast USSR, in Reference cross-sections of the Paleozoic of North USSR: Magadan, USSR Academy of Sciences, Northeast Complex Scientific-Research Institute, p. 3-136 [in Russian].

Nokleberg, W.J., Bundtzen, T.K., Dawson, K.M., Eremin, R.A., Goryachev, N.A., Koch, R.D., Ratkin, V.V., Rozenblum, I.S., Shpikerman, V.I., Diggles, M.F., Frolov, Y.F., Gorodinsky, M.E., Melnikov, V.D., Ognyanov, N.V., Petrachenko, E.D., Petrachenko, R.I., Pozdeev, A.I., Ross, K.V., Wood, D.H., Grybeck, D., Khanchuk, A.I., Kovbas, L.I., Nekrasov, I.Ya., and Sidorov, A.A., 1997a, Significant metalliferous and selected non-metalliferous lode deposits and placer districts for the Russian Far East, Alaska, and the Canadian Cordillera: U.S. Geological Survey Open-File Report 96-513-B (CD-ROM format).

Nokleberg, W.J., Bundtzen, T.K., Dawson, K.M., Eremin, R.A., Goryachev, N.A., Koch, R.D. Ratkin, V.V., Rozenblum, I.S., Shpikerman, V.I., Frolov, Y.F., Gorodinsky, M.E., Melnikov, V.D., Ognyanov, N.V., Petrachenko, E.D., Petrachenko, R.I., Pozdeev, A.I., Ross, K.V., Wood, D.H., Grybeck, D., Khanchuk, A.I., Kovbas, L.I., Nekrasov, I.Ya., and Sidorov, A.A., 1996, Significant metalliferous and selected non-metalliferous lode deposits placer districts for the Russian Far East, Alaska, and the Canadian Cordillera: U.S. Geological Survey Open-File Report 96-513-A (paper format), $385 \mathrm{p}$.

Nokleberg, W.J., Bundtzen, T.K., Grybeck, D., Koch, R.D., Eremin, R.A., Rozenblum, I.S., Sidorov, A.A., Byalobzhesky, S.G., Sosunov, G.M., Shpikerman, V.I., and Gorodinsky, M.E., 1993, Metallogenesis of mainland Alaska and the Russian Northeast: mineral deposit maps, models, and tables, metallogenic belt maps and interpretation, and references cited: U.S. Geological Survey Open-File Report 93-339, 222 pages, 6 sheets, scales $1: 4,000,000,1: 10,000,000$.

Nokleberg, W.J., Foster, H.L., and Aleinikoff, J.N., 1995a, Tectonic model for the Yukon-Tanana, Seventymile, Stikinia, and Wrangellia terranes along the Trans-Alaskan Crustal Transect (TACT), East-Central Alaska [abs.]: Geological Society of America Abstracts with Programs, v. 27, p. 69.

Nokleberg, W.J., Jones, D.L., and Silberling, N.J., 1985, Origin, migration, and accretion of Andean-type arc and island arc tectonostratigraphic terranes in the southern Mount Hayes quadrangle and adjacent areas of the eastern Alaska Range, Alaska: Geological Society of America Bulletin, v. 96, p. 1251-1270.

Nokleberg, W.J., Monger, J.W.H., and Parfenov, L.M., 1995b, Mesozoic and Cenozoic tectonics of the Circum-North Pacific [abs.]: Geological Association of Canada Annual Meeting Program with Abstracts, v. 20, p. A-76 [also Geological Society of America Abstracts with Programs, v. 27, p. A-68 to A-69, and American Geophysical Union Fall Meeting, 1995, Program, p. F592].

Nokleberg, W.J., Parfenov, L.M., Monger, J.W.H., Baranov, B.V., Byalobzhesky, S.G., Bundtzen, T.K., Feeney, T.D., Fujita, Kazuya, Gordey, S.P., Grantz, Art, Khanchuk, A.I., Natal'in, B.A., Natapov, L.M., Norton, I.O., Patton, W.W., Jr., Plafker, George,
Scholl, D.W., Sokolov, S.D., Sosunov, G.M., Stone, D.B., Tabor, R.W., Tsukanov, N.V., and Vallier, T.L., 1997b, Summary CircumNorth Pacific tectono-stratigraphic terrane map: Geological Survey of Canada Open-File 3428, scale 1:10,000,000.

1997c, Summary Circum-North Pacific tectono-stratigraphic terrane map: U.S. Geological Survey Open-File Report 96-727, scale $1: 10,000,000$.

Nokleberg, W.J., Parfenov, L.M., Monger, J.W.H., Baranov, B.V., Byalobzhesky, S.G., Bundtzen, T.K., Feeney, T.D., Fujita, Kazuya, Gordey, S.P., Grantz, Art, Khanchuk, A.I., Natal'in, B.A., Natapov, L.M., Norton, I.O., Patton, W.W., Jr., Plafker, George, Scholl, D.W., Sokolov, S.D., Sosunov, G.M., Stone, D.B., Tabor, R.W., Tsukanov, N.V., Vallier, T.L. and Wakita, Koji, 1994a, Circum-North Pacific tectono-stratigraphic terrane map: U.S. Geological Survey Open-File Report 94-714, 210 p., 4 sheets, scales 1:5,000,000, 1:10,000,000.

Nokleberg, W.J., Plafker, George, Lull, J.S., Wallace, W.K., and Winkler, G.W., 1989, Structural analysis of the southern Peninsular, southern Wrangellia, and northern Chugach terranes along the Trans-Alaskan Crustal Transect (TACT), northern Chugach Mountains, Alaska: Journal of Geophysical Research, v. 94, p. 4297-5320.

Nokleberg, W.J., Plafker, George, and Wilson, F.H., 1994b, Geology of south-central Alaska, in Plafker, George, and Berg, H.C., eds., The geology of Alaska (The Geology of North America, v. G-1): Boulder, Colo., Geological Society of America, p. 311-366.

Nokleberg, W.J., West, T.D., Dawson, K.M., Shpikerman, V.I., Bundtzen, T.K., Parfenov, L.M., Monger, J.W.H., Ratkin, V.V., Baranov, B.V., Byalobzhesky, S.G., Diggles, M.F., Eremin, R.A., Fujita, Kazuya, Gordey, S.P., Gorodinskiy, M.E., Goryachev, N.A., Feeney, T.D., Frolov, Y.F., Grantz, Art, Khanchuk, A.I., Koch, R.D. Natal'in, B.A., Natapov, L.M., Norton, I.O., Patton, W.W. Jr., Plafker, George, Pozdeev, A.I., Rozenblum, I.S., Scholl, D.W., Sokolov, S.D., Sosunov, G.M., Stone, D.V., Tabor, R.W., Tsukanov, N.V., and Vallier, T.L., 1998, Summary terrane, mineral deposit, and metallogenic belt maps of the Russian Far East, Alaska, and the Canadian Cordillera: U.S. Geological Survey Open-File Report 98-136, CD-ROM.

Okada, H., Tarduno, J.A., Nakaseko, K., Nishimura, A., and Sliter, W.V., 1989, Microfossil assemblages from the Late Jurassic to Early Cretaceous Nikoro pelagic sediments, Tokoro Belt, Hokkaido, Japan: Kyushyu University, Faculty of Science Memoirs, ser. D, v. 26, p. 193-214.

Oldow, J.S., Bally, A.W., Avé Lallement, H.G., and Leeman, W.P., 1989, Phanerozoic evolution of the North American Cordillera, in Bally, A.W., and Palmer, A.R., eds., The geology of North America-an overview (The Geology of North America, v. A): Boulder, Colo., Geological Society of America, p. 139-232.

Oleinikov, A.V., Kovalenko, S.V., Nevolina, S.I., Volynets, E.B., and Markevich, S.V., 1990, New data on stratigraphy of upper Mesozoic deposits of the northern Partizansk coal-bearing basin; continental Cretaceous of the USSR, in Collection of research papers: Vladivostok, USSR Academy of Sciences, Far Eastern Branch, p. 114-126 [in Russian].

Oradovskaya, M.M., 1974, Stratigraphy and paleogeography of Ordovician deposits in the Omolon massif, in Reference crosssections of the Paleozoic in northeast USSR: Magadan, USSR Academy of Sciences, North-East Complex ScientificResearch Institute, p. 137-160 [in Russian].

Orchard, M.J., and Danner, W.R., 1991, Paleontology of Quesnellia, in Smith, P.L., ed., A field guide to the paleontology of southwestern Canada: Canadian Paleontology Conference 1, Vancouver, p. 139-159. 
Otofuji, Y., Matsuda, T., Itaya, T., Shibata, T., Matsumoto, M., Yamamoto, T., Morimoto, C., Kulinich, R.G., Zimin, P.S., Matunin, A.P., Sakhno, V.G., and Kimura, K., 1995, Late Cretaceous to early Paleocene paleomagnetic results from Sikote Alin, Russian Far East; implications for deformation of East Asia: Earth and Planetary Science Letters, v. 130, p. 95-108.

Oxman, V.S., Parfenov, L.M., Prokopiev, A.V., Timofeev, V.F., Tretyakov, F.F., Nedosekin, Y.D., Lyer, P.W., and Fujita, Kazuya, 1995, The Chersky Range ophiolite belt, northeast Russia: Journal of Geology, v. 103, p. 539-556.

Packer, D.R., and Stone, D.B., 1974, Paleomagnetism of Jurassic rocks from southern Alaska and their tectonic implications: Canadian Journal of Earth Sciences, v. 7, p. 976-997.

Paek, R.J., Kan, H.G., Jon, G.Pu., Kim, Y.M., Kim, Y.H., eds., 1993, Geology of Korea: Pyongyang, Foreign Languages Book Publishing House, $620 \mathrm{p}$.

Pallister, J.S., Budahn, J.R., and Murchey, B.L., 1989, Pillow basalts of the Angayucham terrane; oceanic plateau and island crust accreted to the Brooks Range: Journal of Geophysical Research, v. 94, no. B, p. 15901-15924.

Pallister, J.S., and Carlson, Christine, 1988, Bedrock geologic map of the Angayucham Mountains, Alaska: U.S. Geological Survey Miscellaneous Field Studies Map MF-2024, scale 1:63,360.

Palmer, A.R., 1983, The Decade of North American Geology, geologic time scale: Geology, v. 11, p. 503-504.

Palmer, A.R., Egbert, R.M., Sullivan, R., and Knoth, J.S., 1985, Cambrian trilobites with Siberian affinities, southwestern Alaska [abs.]: American Association of Petroleum Geologists Bulletin, v. 69, p. 295.

Panuska, B.C., 1980, Stratigraphy and sedimentary petrology of the Kiska Harbor Formation: Fairbanks, University of Alaska, M.S. thesis, $90 \mathrm{p}$.

1984, Paleomagnetism of the Wrangellia and Alexander terranes and the tectonic history of southern Alaska: Fairbanks, University of Alaska, Ph.D. thesis, $197 \mathrm{p}$.

1985, Paleomagnetic evidence for a post-Cretaceous accretion of Wrangellia: Geology, v. 13, p. 880-883.

Panuska, B.C., Decker, J.E., and Berg, H.C., 1984, A preliminary paleomagnetic study of the Gravina-Nutzotin belt, southern and southeastern Alaska, in Coonrad, W.L., and Elliott, R.L. eds., The United States Geological Survey in Alaska; accomplishments during 1981, U.S. Geological Survey Circular, 868, p. 117-120.

Panuska, B.C., and Macicak, M.A., 1986, Revised paleolatitude for the Paleocene Teklanika Volcanics, central Alaska Range, Alaska [abs.]: Eos (American Geophysical Union Transactions), v. 67, p. 921.

Panuska, B.C., and Stone, D.B., 1981, Late Paleozoic paleomagnetic data for Wrangellia; resolution of the polarity ambiguity: Nature, v. 293, p. 561-563.

-1985a, Confirmation of the pre-50 m.y. accretion age of the southern Alaska superterrane [abs.]: Eos (American Geophysical Union Transactions), v. 66, p. 863.

1985b, Latitudinal motion of the Wrangellia and Alexander terranes and southern Alaska superterrane, in Howell, D.B., ed., Tectonostratigraphic terranes of the Circum-Pacific region (Earth Science Series, v. 1): Houston, Tex., Circum-Pacific Council for Energy and Mineral Resources, p. 109-120.

Panuska, B.C., Stone, D.B., and Turner, D.L., 1990, Paleomagnetism of Eocene volcanic rocks, Talkeetna Mountains, Alaska: Journal of Geophysical Research, v. 95, no. B, p. 6737-6750.

Parfenov, L.M., 1984, Continental margins and island arcs of Mesozoides of northeastern Asia: Novosibirsk, Nauka, 192 p. [in Russian].
1985, The segmentation and fold dislocations of the Verkhoyansk foldbelt: Geologiya i Geofizika, no. 7, p. 12-24 [in Russian] 1987, Thrusts and related melanges in the Kharaulakh Mountains: Akademii Nauk SSSR Doklady, v. 296, no. 3, p. 685-689 [in Russian].

1991, Tectonics of the Verkhoyansk-Kolyma Mesozoides in the context of plate tectonics: Tectonophysics, v. 199, p. 319-342.

1994, Accretionary history of northeast Asia, in Thurston, D., and Fujita, Kazuya, eds., Proceedings of 1994 International Conference on Arctic Margins: Anchorage, U.S. Minerals Management Service, p. 183-188.

1995a, Terrane analysis of the Mesozoic orogenic belts of the Russian Northeast [abs.]: Geological Society of America Abstracts with Programs, v. 27, p. 70-71.

1995b, Terranes and formation of the Mesozoic orogenic belts of eastern Yakutia: Tikhookeanskaya Geologiya, v. 14, no.6, p. 32-43 [in Russian].

1995c, Tectonics and regional metallogeny of the Verkhoyansk-Kolyma region, in Bundtzen, T.K., Fonesca, A.L., and Mann, R., eds., The geology and mineral deposits of the Russian Far East: Anchorage, Glasier House Publications and Alaska Miners Association, p. 61-84.

1997, Geological structure and geological history of Yakutia, in Parfenov, L.M., and Spektor, V.B., eds., Geological monuments of the Sakha Republic (Yakutia): Novosibirsk, Studio Design, p. $60-77$.

Parfenov, L.M., Layer, P., Stone, D.B., and Fujita, Kazuya, 1996, Mesozoic orogenic belts of Eastern Yakutia and some problems related to their study: Nauka i Obrazovanie, no. 1, p. 38-44 [in Russian].

Parfenov, L.M., and Natal'in, B.A., 1985, Mesozoic accretion and collision tectonics of northeastern Asia, in Howell, D.G., ed., Tectonostratigraphic terranes of the Circum-Pacific region (Earth Science Series, v. 1): Houston, Tex., Circum-Pacific Council for Energy and Mineral Resources, p. 363-374.

1986, Mesozoic tectonic evolution of northeastern Asia: Tectonophysics, v. 127, p. 291-304.

Parfenov, L.M., Natapov, L.M., Sokolov, S.D., and Tsukanov, S.D., 1993a, Terrane analysis and accretion in northeast Asia: Island Arc, v. 2, p. 35-54.

1993b, Terranes and accretionary tectonics of northeastern Asia: Geotectonics, v. 27, p. 62-72 [in Russian].

Parfenov, L.M., Oxman, V.S., Prokopiev, A.V., Rozhin, S.S., Timofeev, V.F., and Tret'yakov, F.F., 1989, Detailed structural studies in the Verkhoyansk region, their significance for large-scale geological mapping, in Tectonic investigations in connection with medium and large-scale geological mapping: Moscow, Nauka, p. 109-127 [in Russian].

Parfenov, L.M., Popeko, V.A., and Popeko, L.I., 1983, Major structural-material complexes of Shikotan Island and their geologic nature (Minor Kuril Islands): Geologiya i Geofizika, no. 10, p. 24-31 [in Russian].

Parfenov, L.M., and Prokopiev, A.V., 1993, Frontal thrust structures of the Verkhoyansk foldbelt: Geologiya i Geofizika, v. 34, no. 7, p. 23-34 [in Russian].

Parfenov, L.M., Prokopiev, A.V., and Gaiduk, V.V., 1995, Cretaceous frontal thrusts of the Verkhoyansk fold belt, eastern Siberia: Tectonics, v. 4, p. 342-358.

Parfenov, L.M., Voinova, I.P., Natal'in, B.A., and Semonov, 1978, Geodynamics of northeastern Asia in Mesozoic and Cenozoic time and the nature of volcanic belts: Journal of Physics of the Earth, v. 26, supp., p. 5503-5525.

Parrish, R.R., Carr, S.D., and Parkinson, D.L., 1988, Eocene extensional 
tectonics and geochronology of the southern Omineca Belt, British Columbia and Washington: Tectonics, v.7, p. 181-212.

Parrish, R.R., and McNicoll, V., 1992, U-Pb age determinations from the southern Vancouver Island area, British Columbia, in Radiogenic age and isotope studies, report 5: Geological Survey of Canada Paper 91-2, p. 97-108.

Patton, W.W., Jr., 1973, Reconnaissance geology of the northern Yukon-Koyukuk Province, Alaska: U.S. Geological Survey Professional Paper 774-A, p. A1-A17.

1991, Deep crustal composition of the Yukon-Koyukuk basin, Alaska [abs.]: Geological Society of America Abstracts with Programs, v. 23, p. 88.

1992a, Ophiolitic terrane of western Brooks Range, Alaska: U.S. Geological Survey Open-File Report 92-90-D, 8 p. 1992b, Ophiolitic terrane bordering the Yukon-Koyukuk basin, Alaska: U.S. Geological Survey Open-File Report 92-90-F, 8 p.

Patton, W.W., Jr., Box, S.E., Moll-Stalcup, E.J., and Miller, T.P., 1994, Geology of west-central Alaska, in Plafker, George, and Berg, H.C., eds., The geology of Alaska (The Geology of North America, v. G-1): Boulder, Colo., Geological Society of America, p. 241-270.

Patton, W.W., Jr., Murphy, J.M., Burns, L.E., Nelson, S.W., and Box, S.E., 1992, Geologic map of ophiolitic and associated volcanic arc and metamorphic terranes of Alaska (west of the 141st meridian): U.S. Geological Survey Open-File Report 92-20-A, 1 sheet, scale 1:2,500,000.

Patton, W.W., Jr., Tailleur, I.L., Brosgé, W.P., and Lanphere, M.A., 1977, Preliminary report on ophiolites of northern and western Alaska, in Coleman, R.G., and Irwin, W.P., eds., North American ophiolites: Oregon Department of Geology and Mineral Industries Bulletin 95, p. 51-57.

Pavlis, T.L., 1983, Pre-Cretaceous crystalline rocks of the western Chugach Mountains, Alaska; nature of the basement of the Jurassic Peninsular terrane: Geological Society of America Bulletin, v. 94, p. 1329-1344.

Pavlis, T.L., Sisson, V.B., Foster, H.L., Nokleberg, W.J., and Plafker, George, 1993, Mid-Cretaceous extensional tectonics of the Yukon-Tanana terrane, Trans-Alaskan Crustal Transect (TACT), east-central Alaska: Tectonics, v. 12, p. 103-122.

Pavlov, V.E., 1993, Paleomagnetic directions and paleomagnetic pole positions; data for the former USSR-Soviet Geophysical Committee: Moscow, World Data Center-B, Catalog, no. 8, as quoted in Lock and McElhinny (1991).

Pavlov, V.E., Manukyan, A.M., Sharkovskiy, M.B., and Levashova, N.M., 1991, First paleomagnetic data on the Riphean of the Okhotsk massif: Akademii Nauk SSSR Doklady, v. 317. p. 688-892 [in Russian].

Pechersky, D.M., 1970, Paleomagnetic studies of Mesozoic deposits of the USSR northeast: Physics of the Earth Izvestiya, v. 6, p. 69-83.

1979, Paleomagnetic directions and paleomagnetic pole positions: data for the former USSR-Soviet Geophysical Committee: Moscow, World Data Center-B, Catalog, no. 4, as quoted in Lock and McElhinny (1991).

Pechersky, D.M., and Shapiro, M.N., 1996, Paleomagnetism of Upper Cretaceous and Paleogene volcanogenic series of Eastern Kamchatka; evidence for absolute motions of ancient subduction zones: Physics of the Earth Izvestiya, v. 32, p. 114-137.

Petocz, R.G., 1970, Biostratigraphy and Lower Permian Fusilinidae of the upper Delta River area, east-central Alaska Range, Alaska: Geological Society of America Special Paper 130, 94 p.

Plafker, George, Blome, C.D., and Silberling, N.J., 1989a, Reinterpretation of lower Mesozoic rocks on the Chilkat Peninsula, Alaska, as a displaced fragment of Wrangellia: Geology, v. 17, p. 3-6.

Plafker, George, and Berg, H.D., 1994, Overview of the geology and tectonic evolution of Alaska, in Plafker, George, and Berg, H.C., eds., The geology of Alaska (The Geology of North America, v. G-1): Boulder, Colo., Geological Society of America, p. 989-1021.

Plafker, George, Moore, J.C., and Winkler, G.R., 1994, Geology of the southern Alaska margin, in Plafker, George, and Berg, H.C., eds., The Geology of Alaska (The Geology of North America, v. G-1): Boulder, Colo., Geological Society of America, p. 989-1021.

Plafker, George, Nokleberg, W.J., and Lull, J.S., 1989b, Bedrock geology and tectonic evolution of the Wrangellia, Peninsular, and Chugach terranes along the Trans-Alaskan Crustal Transect in the northern Chugach Mountains and southern Copper River basin, Alaska: Journal of Geophysical Research, v. 94, p. $4255-4295$.

Plumley, P.W., 1984, A paleomagnetic study of the Prince William terrane and the Nixon Fork terrane, Alaska: Santa Cruz, University of California, Ph.D. thesis, $190 \mathrm{p}$.

Plumley, P.W., Coe, R.S., and Byne, T., 1983, Paleomagnetism of the Paleocene Ghost Rocks formation, Prince William terrane, Alaska: Tectonics, v. 2, p. 295-311.

Plumley, P.W., and Vance, M., 1988, Porcupine river basalt field, NE Alaska; age, paleomagnetism and tectonic significance [abs.]: Eos (American Geophysical Union Transactions), v. 69, p. 1458.

Polubotko, I.V., Paraketsov, K.B., and Repin, Yu.S., 1977, Jurassic structural-stratigraphic areas in the northeastern U.S.S.R.; materials on the geology and mineral resources of the U.S.S.R. Northeast: Magadan, U.S.S.R. Academy of Sciences, v. 23, p. 42-51 [in Russian].

Pope, M.C., and Sears, J.W., 1997, Cassiar platform, north-central British Columbia; a miogeoclinal fragment from Idaho: Geology, v. 25, p. 515-518.

Popolitov, E.I., and Volynets, O.V., 1981, Geochemical features of Quaternary volcanism of the Kuril-Kamchatka island arc and some aspects of petrogenesis: Novosibirsk, Nauka, 182 p. [in Russian].

Prokopiev, A.V., 1989, Kinematics of Mesozoic folding in the western part of the south Verkhoyan'ye: U.S.S.R. Academy of Sciences, Yakutsk Science Center, 128 p. [in Russian].

Pushcharovskiy, Yu.M., and Til'man, S.M., eds., 1982, Essays on tectonics of the Koryak Highland: Moscow, Nauka, 219 p. [in Russian].

Ramthun, Alexander, Brandon, M.T., and Ring, Ewe, 1997, Preservation of sedimentary fabrics in the footwall of the large-slip Vatyna thrust, Kamchatka, Russian Far East [abs.]: Geological Society of America Abstracts with Programs, v. 29, p. 58.

Raznitsi, Yu.N., 1982, Ophiolite allochthons and adjacent deep-water basins in the western Pacific: Moscow, Nauka, 108 p. [in Russian].

Read, P.B., and Okulitch, A.V., 1977, The Triassic unconformity of south-central British Columbia: Canadian Journal of Earth Science, v. 14, p. 606-638.

Richards, B.C., Bamber, E.W., Henderson, C.M., Higgins, A.C., Johnston, D.J., Mamer, B., and Meijer Drees, M.J., 1994, Uppermost Devonian (Famennian) and Lower Carboniferous (Tournasian) at Jura Creek and Mount Rundle, southwestern Alberta: Geological Survey of Canada Open File 2866, $79 \mathrm{p}$.

Richards, D.R., Butler, R.F., and Harms, T.A., 1993, Paleomagnetism of the late Paleozoic Slide Mountain terrane, northern and central British Columbia: Canadian Journal of Earth Sciences, v. 30, p. 1898-1913. 
Richards, M.A., Jones, D.L., Duncan, R.A., and DePaolo, D.J., 1991, A mantle plume initiation model for the formation of Wrangellia and other oceanic plateaus: Science, v. 254, p. 263-267.

Ricketts, B.D., Evenchick, C.A., Anderson, R.G., and Murphy, D.C., 1992, Bowser Basin, northern British Columbia; constraints on the timing of initial subsidence and Stikinia-North America terrane interactions: Geology, v. 20, p. 1119-1122.

Riegel, S.A., Fujita, Kazuya, Koz'min, B.M., Imaev, V.S., and Cook, D.B., 1993, Extrusion tectonics of the Okhotsk plate, northeast Asia: Geophysical Research Letters, v. 20, p. 607-610.

Rikhter, A.V., 1986, The structure and tectonic evolution of Sakhalin Island in Mesozoic time: Moscow, Nauka, 90 p. [in Russian].

Roback, R.C., Sevigny, J.H., and Walker, N.W., 1994, Tectonic setting of the Slide Mountain terrane, southern British Columbia: Tectonics, v. 13, p. 1242-1258.

Roe, J.R., and Stone, D.B., 1993, Paleomagnetism of the Fairbanks basalts, interior Alaska, in Solie, D.N., and Tannian, F., eds., Short notes on Alaskan geology: Alaska Division of Geological and Geophysical Surveys Professional Report 113, p. 61-69.

Roganov, G.V., Sobolev, L.P., and others, 1986, Uda-Shantarsk phosphorite-bearing basin: Novosibirsk, Nauka, 168 p. [in Russian].

Ross, C.A., and Ross, J.R.P. 1983, Late Paleozoic accreted terranes of western North America, in Stevens, C.H., ed., Pre-Jurassic rocks of western North American suspect terranes: Los Angeles, Society of Economic Paleontologists and Mineralogists, Pacific Section, p. 7-22.

Ross, B.M., Parrish, R.R., and Winston, Don, 1992, Provenance and $\mathrm{U}-\mathrm{Pb}$ geochronology of the Mesoproterozoic Belt Supergroup (northwestern United States); implications for age of deposition and pre-Panthalassa plate reconstructions: Earth and Planetary Science Letters, v. 113, p. 57-76.

Rozhdestvensky, V.S., 1987, Tectonic evolution of the Sakhalin Island: Tikhookeanskaya Geologia, no. 3, p. 42-51 [in Russian].

Rozhdestvensky, V.S., 1993, Geodynamic evolution of the HokkaidoSakhalin fold system: Tikhookeanskaya Geologiya, no. 2, p. 76-88 [in Russian].

Rubin, C.M., Miller, M.M., and Smith, G.M., 1991, Tectonic development of Cordilleran mid-Paleozoic volcano-plutonic complexes; evidence for convergent margin tectonism, in Harwood, D.S., and Miller, M.M., eds., Paleozoic and early Mesozoic paleogeographic relations of the Sierra Nevada, Klamath Mountains, and related terranes: Geological Society of America Special Paper 225, p. 1-16.

Rudenko, V.S., and Panasenko, E.S., 1990, Permian radiolaria of the Pantovy Creek member of the Primorye region, in Zakharov, Y.D., Belyaeva, G.V., and Nikitina, A.P., eds., New data on the Paleozoic and Mesozoic biostratigraphy of the southern Russian Far East: Vladivostok, U.S.S.R. Academy of Sciences, p. 181-193 [in Russian].

Rusakov, I.M., Florova, Z.B., Bondarenko, N.S., and others, 1977, Stratigraphy of Mesozoic deposits of the Alzaeya Plateau: Geologiya i Geofizika, no. 8, p. 129-133 [in Russian].

Rusakov, I.M., Kats, A.G., Bondarenko, N.S., and others, 1975, New data on the Paleozoic stratigraphy of the Alazeya Plateau: Akademii Nauk SSSR Doklady, v. 223, no. 1, p. 178-181 [in Russian].

Rusmore, M.E., 1987, Geology of Cadwallader Group and the Intermontane-Insular superterrane boundary: Canadian Journal of Earth Sciences, v. 24, p. 2279-2291.

Sakai, A., and Kanie, H., 1986, Geology of the Nishicha district, Japan: Geological Survey of Japan, 92 p., scale 1:50,000.

Sakhno, V.G., 1984, Volcanic zones on the ancient Pre-Cambrian consolidated substrate; volcanic belts of Eastern Asia: Moscow, Nauka, p. 160-177 [in Russian].
Saleeby, J.B. 1983, Accretionary tectonics of the North American Cordillera: Annual Reviews of Earth and Planetary Science, v. 15, p. 45-73.

Sampson, S.D., Patchett, P.J., McClelland, W.C., and Gehrels, G.E., 1991, Nd isotopic characterization of metamorphic rocks in the Coast Mountains, Alaska and Canadian Cordillera; ancient crust bounded by juvenile terranes: Tectonics, v. 10, p. 770-780.

Savostin, L.A., and Drachev, S.S., 1988a, Some features of the geologic structure and tectonics of southern Bol'shoi Lyakhov Island (New Siberian Islands): USSR Academy of Sciences Doklady, v. 301, p. 169-172 [in Russian].

1988b, Cenozoic compression in the vicinity of the Novosibirskiy Islands and its relationship to the opening of the Eurasia Basin: Oceanology, v. 28, p. 601-606.

Savostin, L.A., Karasik, A.M., and Zonenshain, L.P., 1984, The history of the opening of the Eurasia Basin in the Arctic: Academy of Sciences of the USSR Doklady, Earth Science Section, v. 275, p. 79-83.

Savostin, L.A., and Kheyfets, A.M., 1989, Paleomagnetic directions and pole positions; data for the USSR-Soviet Geophysical Committee: Moscow, World Data Center-B, Catalog, no. 7, as quoted in Lock and McElhinny (1991).

Scammell, R.J., and Brown, R.L., 1990, Cover gneisses of the Monashee Terrane; a record of synsedimentary rifting in the North American Cordillera: Canadian Journal of Earth Sciences, v. 27, p. 712-726.

Scheglov, S.B., 1984, Volcanic belts of eastern Asia; geology and metallogeny: Moscow, Nauka, 504 p. [in Russian].

Scholl, D.W., and Hart, P.E., 1994, Velocity and amplitude structures on seismic reflection profiles-possible massive gas-hydrate deposits and underlying gas accumulations in the Bering Sea Basin, in Howell, D.G., ed., The future of energy gases: U.S. Geological Survey Professional Paper 1570, p. 331-351.

Scholl, D.W., Stevenson, A.J., Mueller, S., Geist, E.L., Engebretson, D.C., and Vallier, T.L., 1992, Exploring the notion that southeastAsian-type escape tectonics and trench clogging are involved in regional-scale deformation of Alaska and the formation of the Aleutian-Bering Sea region, in Flower, M., McCabe, R., and Hilde, T., eds., Southeast Asia structure, tectonics, and magmatism: Texas A\&M University, Geodynamics Research Institute Symposium, College Station, Tex., 1992, Proceedings, p. 57-63.

Scholl, D.W., Stevenson, A.J., Mueller, S., Geist, E.L., Vallier, T.L., and Engebretson, D.C., 1994, Regional-scale strain partitioning leading to escape tectonism and formation of offshore arctrench systems, Alaska-Aleutian-Bering Sea region: Geological Society of America Abstracts with Programs, v. 26, p. 136.

Schwarz, E.J., Muller, J.E., and Clark, K.R., 1980, Paleomagnetism of the Karmutsen basalts from southeast Vancouver Island: Canadian Journal of Earth Sciences, v. 17, p. 389-399.

Scotese, C.R., 1997, Continental drift, Phanerozoic plate tectonic reconstructions: Arlington, University of Texas, Department of Geology, PALEOMAP Progress Report 36, edition 7 (CD-ROM).

Seliverstov, N.I., Baranov, B.V., Egorov, Yu.O., and Shkira, V.A., 1988, New data on the structure of the southern Komandorsky Basin obtained by R/V Vulkanolog (26th Cruise): Volcanology and Sedimentology, no. 4, p. 3-20 [in Russian].

Semenov, D.F., 1982. Magmatic formations of the Pacific fold systems (in the case of Sakhalin Island): Moscow, Nauka, 168 p. [in Russian].

Sengör, A.M.C., 1990, Plate tectonics and orogenic research after 25 years; a Tethyan perspective: Earth Science Reviews, Elsevier Science Publishers, v. 27, p. 1-201. 
Sengör, A.M.C., and Natal'in, B.A., 1996a, Paleotectonics of Asia; fragments of a synthesis, in Yin, An, and Harrison, Mark, eds., The tectonic evolution of Asia: Cambridge, U.K., Cambridge University Press, p. 486-640.

1996b, Turkic-type orogeny and its role in the making of continental crust: Annual Reviews Earth and Planetary Sciences, v. 24, p. 263-337.

Sengör, A.M.C., Natal'in, B.A., and Burtman, V.S., 1993, Evolution of the Altaid tectonic collage and Paleozoic crustal growth in Eurasia: Nature, v. 364, p. 299-307.

1994, Tectonic evolution of the Altaid: Geology and Geophysics, v. 78, p. 41-59.

Sergeyev, K.F., and Krasny M.L., eds. 1987, Geologic and geophysical atlas of the Kuril-Kamchatka Island system: Leningrad, Ministry of Geology, VSEGEI, 36 sheets [in Russian and English].

Seslavinskiy, K.B., and Ged'ko, M.I., 1990, Ophiolitic complexes of western Chukotka and geodynamic interpretation of their genesis, in Tectonics and mineralogy of the northeastern U.S.S.R.: Magadan, U.S.S.R. Academy of Sciences, p. 191-194 [in Russian].

Shantser, A.E., Shapiro, M.N., Koloskov, A.V., and others, 1985, Structural evolution of the Lesnovsk uplift and adjacent areas in the Cenozoic (northern Kamchatka): Tikhookeanskaya Geologiya, no. 4, p. 66-74 [in Russian].

Shapiro, M.N., Ermakov, V.A., Shantser, A.E., Shul'dner, V.I., Khanchuk, A.I., and Vysotsky, S.V., 1987, Essays on the tectonic development of Kamchatka: Moscow, Nauka, 247 p. [in Russian].

Shevelev, E.K., 1987, Age of the volcanogenic siliceous and terrigenous deposits of the basement of the Middle Amur basin: Tikhookeanskaya Geologiya, no. 3, p. 13-16 [in Russian].

Shevelev, E.K., and Kuzmin, S.P., 1990, New data on the stratigraphy in the Badzhal zone, in New data on Paleozoic and Mesozoic biostratigraphy of the southern Far East: Vladivostok, U.S.S.R. Academy of Sciences, p. 72-80 [in Russian].

Shkodzinsky, V.S., Nedosekin, Yu.D., and Surnin, A.A., 1992, Petrology of late Mesozoic magmatic rocks in eastern Yakutia: Novosibirsk, Nauka, 238 p. [in Russian].

Shmakin, V.B., 1991, New data on Upper Jurassic deposits of the Koiverelan River Basin: USSR Academy of Sciences Izvestiya, Geological Series, no. 4, p. 31-35 [in Russian].*

Shul'gina, V.S., Tkachenko, V.I., and Kuznetsov, V.M., 1990, Geological map of the U.S.S.R.: Leningrad, U.S.S.R. Ministry of Geology, scale 1:1,000,000 [in Russian].

Silberling, N.J., Jones, D.L., Blake, M.C., Jr., and Howell, D.G., 1984, Lithotectonic terrane map of the western conterminous United States, pt. C of Silberling, N.J., and Jones, D.L., eds., Lithotectonic terrane maps of the North American Cordillera: U.S. Geological Survey Open-File Report 84-523, 43 p.

-1987, Lithotectonic terrane map of the western conterminous United States: U.S. Geological Survey Miscellaneous Field Investigations Map MF-1874-C, scale 1:2,500,000.

Silberling, N.J., Jones, D.L., Monger, J.W.H., and Coney, P.J., 1992, Lithotectonic terrane map of the North American Cordillera: U.S. Geological Survey Miscellaneous Investigations Map I-2176, scale 1:5,000,000.

Simanenko, V.P., 1986, Late Mesozoic volcanic arcs of the East Sikhote Alin and Sakhalin Island: Tikhookeanskaya Geologiya, no. 1, p. 7-13 [in Russian].

Sisson, V.B., Hollister, L.S., and Onstott, T.C., 1989, Petrologic and age constraints on the origin of a low-pressure/high-temperature metamorphic complex, southern Alaska: Journal of Geophysical Research, v. 94, p. 4392-4410.
Sizykh, V.I., Ignat'ev, V.A., and Shkol'nyi, L.D., 1977, New data on the stratigraphy and tectonics on the left bank of Malyi Anyui River, in Materials on the geology and mineral deposits of the northeastern U.S.S.R.: U.S.S.R. Academy of Sciences, Magadan, v. 23, p. 29-34 [in Russian].

Slautsitais, I.P., 1971, Paleomagnetic directions and pole positions: data for the USSR-Soviet Geophysical Committee: Moscow, World Data Center-B, Catalog, no. 1, as quoted in Lock and McElhinny (1991).

Smith, J.G., 1993, Geologic map of upper Eocene to Holocene volcanic and related rocks in the Cascade Range, Washington: U.S. Geological Survey Miscellaneous Investigations Map I-2005, 19 p., scale 1:500,000, 2 sheets.

Smith, M.T., and Gehrels, G.E., 1992, Detrital zircon geochronology of Upper Proterozoic to lower Paleozoic continental margin strata of the Kootenay arc; implications for the early Paleozoic tectonic development of the eastern Canadian Cordillera: Canadian Journal of Earth Sciences, v. 28, p. 1271-1284.

Smith, P.L., and Tipper, H.W. 1986. Plate tectonics and paleobiogeography; Early Jurassic (Pliensbachian) endemism and diversity: Palaios, v. 1, p. 399-412.

Snavely, P.D., Jr., Niem, A.R., MacLeod, N.S., Pearl, J.E., and Rau, W.W., 1980, Makah Formation-a deep marginal-basin sedimentary sequence of late Eocene and Oligocene age in the northwestern Olympic Peninsula, Washington: U.S. Geological Survey Professional Paper 1162-B, $28 \mathrm{p}$.

Sokolov, S.D., 1990, Exotic complexes (terranes) in the Koryak Ridge region: Geologiya i Razvedka, Proceedings of the High Educational Institutions, no. 1, p. 16-29 [in Russian].

1992, Accretionary tectonics of the Koryak-Chukotka segment of the Pacific Belt: Moscow, Nauka, 182 p. [in Russian].

Sokolov, S.D., and Byalobzhesky, S.G., 1996, Terranes of the Koryak Highland: Geotectonics, no. 6, p. 68-80.

Solov'ev, A.V., Brandon, M.T., Garver, Bogdanov, N.A., Shapiro, M.N., and Ledneva, G.V., 1998, Collision of the Olyutor island arc with the Eurasian continental margin; kinematic and age aspects: Earth Sciences Doklady, v. 361, p. 632-634.

Solov'eva, M.F., 1975, Biostratigraphy of Lower and middle Carboniferous deposits of Kotel'nyi and Wrangel Island and Chukotka based on foraminifera, in The Upper Paleozoic of Northeast USSR: Leningrad, Nauka, p. 42-53 [in Russian].

Sontag, L.J., and Panuska, B.C., 1990, Paleomagnetic data from Triassic intrusives in the Wrangell Mountains, Alaska; implications for the age of magnetization of Paleozoic rocks: State College, Mississippi State University, Sigma Gamma Epsilon Compass, v. 67, p. 263-268.

Sosunov, G.M., 1985, Geologic map of Northeast U.S.S.R.: Magadan, U.S.S.R. Ministry of Geology, Northeastern Production and Geological Association, scale 1:5,000,000. [in Russian].

Sosunov, G.M., Pavlova, O.K., and Gel'man, M.L., 1982, Geologic map of the northeastern U.S.S.R.: Magadan, U.S.S.R. Ministry of Geology, 39 p., scale 1:1,500,000 [in Russian].

Srivastava, S.P., and Tapscott, C.R., 1986, Plate kinematics of the North Atlantic, in Vogt, P., and Tucholke, B.E., eds., The western North Atlantic region (The Geology of North America, v. M): Boulder, Colo., Geological Society of America, p. 379-405.

Stamatakos, J., Kodama, K.P., and Pavlis, T.L., 1986, Paleomagnetic study of early Tertiary sediments along the Castle Mountain Fault, Matanuska Valley, Alaska [abs.]: Eos (American Geophysical Union Transactions), v. 67, p. 921

1987, Paleomagnetism of Eocene plutonic rocks, Matanuska Valley, Alaska, and their tectonic significance [abs.]: Eos (American Geophysical Union Transactions), v. 68, p. 291. 
1988, Paleomagnetism of Eocene volcanic rocks, Matanuska Valley, Alaska: Geology, v. 16, p. 618-622.

Stamatakos, J., Kodama, K.P., Vittorio, L.F. and Pavlis, T.L., 1989, Paleomagnetism of Cretaceous and Paleocene sedimentary rocks across the Castle Mountain Fault, south-central Alaska, in Hillhouse, J.W., ed., Deep structure and past kinematics of accreted terranes: American Geophysical Union and International Union Geodesy and Geophysics Geophysical Monograph 50, p. 151-177.

Stanley, W.D., Labson, V.F., Nokleberg, W.J., Csejtey, Béla, Jr., and Fisher, M.A., 1990, The Denali fault system and Alaska Range of Alaska; evidence for suturing and thin-skinned tectonics from magnetotellurics: Geological Society of America Bulletin, v. 102, p. $160-173$.

Stavsky, A.P., Berezner, O.S., Safonov, V.G., and Zlobin, S.K., 1989, Tectonics of the Mainits zone of the Koryak Highland: Tikhookeanskaya Geologiya, no. 3, p. 72-81 [in Russian].

Stavsky, A.P., Chekhovich, V.D., Kononov, M.V., and Zonenshain, L.P., 1990, Plate tectonics and palinspastic reconstructions of the Anadyr-Koryak region, northeast USSR: Tectonics, v. 9, p. 81-103.

Stepanov, V.A., and Shishakova, L.N., 1994, Kubaka gold-silver deposit: Vladivostok, Dalnauka, $196 \mathrm{p}$.

Stevens, C.H., Davydov, V.I., and Bradley, D.C., 1997, Permian Tethyan fusilinids from the Kenai Peninsula, Alaska: Journal of Paleontology, v. 71, p. 985-994.

Stone, D.B., 1975, Paleomagnetic studies and tectonics in the Aleutian Islands, in Forbes, R.B., ed., Geology of the Bering Sea region: Geological Society of America Special Paper 151, p. 59-75.

Stone, D.B., Harbert, W., Vallier, T.L., and McLean, H., 1983, Eocene paleolatitudes for the Aleutian Islands [abs.]: Eos (American Geophysical Union Transactions), v. 64, p. 87.

Stone, D.B., and Packer, D.R., 1979, Paleomagnetic data from the Alaska Peninsula: Geological Society of America Bulletin, v. 90 , p. 545-560.

Stone, D.B., Panuska, B.C., and Packer, D.R., 1982, Paleolatitudes versus time for southern Alaska: Journal of Geophysical Research, v. 87, p. 3697-3707.

Struik, L.C., and Orchard, M.J., 1985, Late Paleozoic conodonts from ribbon chert delineate imbricate thrusts within the Antler Formation of the Slide Mountain terrane, central British Columbia: Geology, v. 13, p. 794-798.

Sugimoto, M., 1974, Stratigraphical study in the outer belt of the Kitakami Massif, northeastern Japan: Tohoru University, Institute of Geology and Paleontology Contribution 74, p. 1-48.

Sukhov, S.A., 1975, Volcanic formations of the Far East: Moscow, Nauka, 111 p. [in Russian].

Symons, D.T.A., 1969a, Geological implications of paleomagnetic studies in the Bella Coola and Laredo Sound map-areas, British Columbia: Geological Survey of Canada Paper 68-72, p. 15. 1969b, Paleomagnetism of the Late Miocene plateau basalts in the Caribou region of British Columbia: Geological Survey of Canada Paper, 69-43, p. 15.

1969c, Paleomagnetism of four late Miocene gabbroic plugs in south-central British Columbia: Canadian Journal of Earth Sciences, v. 6, p. 653-662.

1971, Paleomagnetism of the Triassic Guichon batholith and rotation of the southern Interior Plateau, British Columbia: Canadian Journal of Earth Sciences, v. 8, p. 1388-1396. 1973a, Paleomagnetic results from the Jurassic Topley intrusions near Endako, British Columbia: Canadian Journal of Earth Sciences, v. 10, p. 1099-1108. 1973b, Paleomagnetic results from the Tertiary Mt. Barr and Hope plutonic complexes, British Columbia, Geological Survey of Canada Paper 73-19, p. 1-10.

1973c, Concordant Cretaceous paleolatitudes from felsic plutons in the Canadian Cordillera: Nature Physical Sciences, v. 241, p. 59-61.

1973d, Paleomagnetic zones in the Oligocene East Sooke gabbro, Vancouver Island, British Columbia: Journal of Geophysical Research, v. 78, no. B, p. 5100-5109.

1977a, Geotectonics of Cretaceous and Eocene plutons in British Columbia; a paleomagnetic fold test: Canadian Journal of Earth Sciences, v. 14, p. 1245-1262.

1977b, Paleomagnetism of Mesozoic plutons in the westernmost coast complex of British Columbia: Canadian Journal of Earth Sciences, v. 14, p. 2127-2139.

1983a, Further paleomagnetic results from the Jurassic Topley intrusives in the Stikinia subterrane of British Columbia: Geophysical Research Letters, v. 10, p. 1065-1068.

1983b, New paleomagnetic data for the Triassic Guichon batholith and their bearing on terrane I tectonics: Canadian Journal of Earth Sciences, v. 20, p. 1340-1343.

1985a, Paleomagnetism of the west coast complex and the geotectonics of the Vancouver Island segment of the Wrangellian subterrane: Journal of Geodynamics, v. 2, p. 211-228. 1985b, Paleomagnetism of the Triassic Nicola Volcanics and geotectonics of the Quesnellia subterrane of Terrane I, British Columbia: Journal of Geodynamics, v. 2, p. 229-244.

Symons, D.T.A., and Litalien, C., 1984, Paleomagnetism of the Lower Jurassic Copper Mountain Intrusions and the Geotectonics of Terrane I, British Columbia: Geophysical Research Letters, v. 11, p. 685-688.

Symons, D.T.A., and Wellings, M.R., 1989, Paleomagnetism of the Eocene Kamloops Group and the cratonization of Terrane I of the Canadian Cordillera: Canadian Journal of Earth Sciences, v. 26, p. 821-828.

Tabor, R.W., 1994, Late Mesozoic and possible early Tertiary accretion in western Washington State; the Helena-Haystack melange and the Darrington-Devils Mountain fault zone: Geological Society of America Bulletin, v. 106, p. 217-232.

Tabor, R.W., and Cady, W.M., 1978, Geologic map of the Olympic Peninsula: U.S. Geological Survey Miscellaneous Investigations Map I-994, scale 1:125,000.

Taira, A. and Tashino, M., 1987, Late Paleozoic and Mesozoic accretion tectonics in Japan and Eastern Asia; historical biogeography and plate tectonic evolution of Japan and Eastern Asia: Tokyo, Terra Science Publications, p. 1-43.

Tamaki, K. 1988, Geological evolution of the Japan Sea and its tectonic implications: Geological Survey of Japan Bulletin, v. 39, p. 269-365.

Tang, K., Wang, Y., He, G., and Shao, J., 1995, Continental-margin structure of northeast China and its adjacent area: Acta Geologica Sinica (English ed.), v. 8, no. 3, p. 241-258.

Tatsumi, Y., Otoruji, Y.I., Matsuda, T., and Nohda, S., 1989, Opening of the Sea of Japan back-arc basin by asthenospheric injection: Tectonophysics, v. 166, p. 317-329.

Tempelman-Kluit, D.J., 1979, Transported cataclasite, ophiolite, and granodiorite in the Yukon; evidence of arc-continent collision: Geological Survey of Canada Paper 79-14, 27 p.

Teplykh, V.I., and Karavaeva, N.I., 1974, Notes on the stratigraphy of Upper Paleozoic deposits of the Oloy river basin, in The Precambrian and Paleozoic of northeast USSR [abs.]: USSR Interdepartmental Committee on Stratigraphy, Interdepartmental Stratigraphic Meeting, Magadan, 1974, Abstracts, p. 150-153 [in Russian]. 
Terekhov, M.I., 1979, Stratigraphy and tectonics of the southern Omolon massif: Moscow, Nauka, 114 p. [in Russian].

Terekhov, M.I., Lychagin, P.P., and Merzlyakov, V.M., 1984, Geologic map of the Sugoy, Korkodon, Omolon, Oloy, and Gijiiga interfluves: Magadan, U.S.S.R. Ministry of Geology, 144 p., scale 1:500,000 [in Russian].

Thorkelson, D.J., and Smith, A.D., 1989, Arc and intraplate volcanism in the Spences Bridge Group; implications for Cretaceous tectonics in the Canadian Cordillera: Geology, v. 17, p. 1093-1096.

Thrupp, G.A., and Coe, R.S., 1986, Early Tertiary paleomagnetic evidence and the displacement of southern Alaska: Geology, v. 14, p. 213-217.

Till, A.B., and Dumoulin, J.A., 1994, Geology of Seward Peninsula and Saint Lawrence Island, in Plafker, George, and Berg, H.C., eds., The geology of Alaska: Boulder, Colo., Geological Society of America, The Geology of North America, v. G-1, p. 141-152.

Tipper, H.W., and Richards, T.A., 1976, Jurassic stratigraphy and history of north-central British Columbia: Geological Survey of Canada Bulletin 720, 73 p.

Tozer, E.T., 1982, Marine Triassic faunas of North America; their significance for assessing plate and terrane movements: Geologische Rundschau, v. 71, p. 1077-1104.

Travers, W.B., 1978, Overturned Nicola and Ashcroft strata and their relation to the Cache Creek Group, southwestern Intermontane Belt, British Columbia: Canadian Journal of Earth Sciences, v. 15, p. 99-109.

Tret'yakov, F.F., 1989, Evolution of tectonic structures in the Kolyma massif: Yakutsk, 140 p. [in Russian].

Trunilina, V.A., and Orlov, Yu.S., 1997, Late Mesozoic longitudinal and transversal granite belts of northeast Yakutia: Nauka i Obrazovanie, no. 1, p. 50-56 [in Russian].

Tsukanov, N.V., 1991, Tectonic evolution of Kamchatka perioceanic area in the late Mesozoic and early Cenozoic: Moscow, Nauka, 104 p. [in Russian].

Tsvetkov, A.A., Fedorchuyk, A.V., and Gladenkov, A.Yu., 1990, Geologic structure and magmatism of Bering Island: Akademii Nauk SSSR Izvestiya, Seriya Geologicheskaya, no. 7, p. 40-56 [in Russian].

Tynankergav, G.A., and Bychkov, Yu.M., 1987, Siliceous, volcanic, and terrigenous Upper Triassic deposits of the western Chukotka Peninsula: Akademii Nauk SSSR Doklady, v. 296, p. 698-700 [in Russian].

Umhoefer, P.J., 1987, Northward translation of “Baja British Columbia" along the Late Cretaceous to Paleocene margin of western North America: Tectonics, v. 6, p. 377-394.

Umitbaev, R.B., 1976, Geological formations of the Okotsk massif, in Parfenov, L.M., and Til'man, S.M., eds., Tectonics of the eastern Soviet Asia: Vladivostok, U.S.S.R. Academy of Sciences, Far East Scientific Center, p. 73-95 [in Russian].

Unrug, Raphael, 1997, Rodinia to Gondwana; the geodynamic map of Gondwana supercontinent assembly: GSA Today, v. 7, p. 1-6.

Uyeda, S., 1986, Facts, ideas, and open problems on trench-arc-backarc systems, in Wezel, F.C., ed., The origin of arcs: Amsterdam, Elsevier, p. 435-460.

Vallier, T.L., 1977, The Permian and Triassic Seven Devils Group, western Idaho and northeastern Oregon: U.S. Geological Survey Bulletin 1437, $58 \mathrm{p}$.

1995, Petrology of pre-Tertiary igneous rocks of the Blue Mountains province of Oregon, Idaho, and Washington; implications for the geologic evolution of a complex island arc, in Vallier, T.L., and Brooks, H.C., eds., Geology of the Blue Mountains region of Oregon, Idaho, and Washington: U.S. Geological Survey Professional Paper 1438, p. 125-209.

Vallier, T.L., and Brooks, H.C., eds., 1995, Geology of the Blue Moun- tains region of Oregon, Idaho and Washington; stratigraphy, physiography, and mineral resources of the Blue Mountains region: U.S. Geological Survey Professional Paper 1439, 198 p.

Vallier, T.L., Brooks, H.C., and Thayer, T.P., 1977, Paleozoic rocks of eastern Oregon and western Idaho, in Stewart, J.H., Stevens, C.H., and Fritsche, A.E., eds., Paleozoic paleogeography of the western United States: Los Angeles, Society of Economic Paleontologists and Mineralogists, Pacific Section, Pacific Coast Paleogeography Symposium 1, p. 455-466.

van der Heyden, P., 1992, A Middle Jurassic to early Tertiary AndeanSierran arc model for the Coast Belt of British Columbia: Tectonics, v. 11, p. 82-97.

Van der Voo, R., 1981, Paleomagnetism of North America, brief review, in McElhinny, M.W., and Valencio, D.A., eds., Paleoreconstruction of the continents (Geodynamics Series, v. 2): Washington, D.C., American Geophysical Union, p. 159-176. 1990, Phanerozoic paleomagnetic poles from Europe and North America and comparisons with continental reconstructions: Reviews of Geophysics, v. 28, p. 167-206.

1993, Paleomagnetics of the Atlantic, Tethys, and lapetus Oceans: Cambridge, U.K., Cambridge University Press, 411 p.

Van der Voo, R., Jones, D.L., Grommé, C.S., Eberlein, G.D. and Churkin, M., 1980, Paleozoic paleomagnetism and northward drift of the Alexander terrane, southeastern Alaska: Journal of Geophysical Research, v. 85, no. B, p. 5281-5296.

Vance, J.A., Clayton, G.A., Mattinson, J.M., and Naeser, C.W., 1987, Early and middle Cenozoic stratigraphy of the Mount RainierTieton River area, southern Washington Cascades, in Schuster, J.E., ed., Selected papers on the geology of Washington: Washington Division of Geology and Earth Resources Bulletin 77, p. 269-290.

Vandall, T.C., and Palmer, H.C., 1990, Canadian Cordilleran displacement: paleomagnetic results from the Early Jurassic Hazelton Group, Terrane I, British Columbia, Canada: Geophysical Journal International, v. 103, p. 609-620.

Varsek, J.L., Cook, F.A., Clowes, R.M., Journeay, J.M., Monger, J.W.H., Parrish, R.R., Kanasewich, E.R., and Spencer, C.S., 1993, Lithoprobe crustal reflection structure of the southern Canadian Cordillera II; Coast Mountains transect: Tectonics, v. 12, p. 334-360.

Vernikovsky, V.V., Vernikovskaya, A.E., and Chernykh, A.I., 1998, Neoproterozoic Taymyr ophiolitic belts and opening of the PaleoPacific 0cean: International Geology Review, v. 40, p. 528-538.

Verzkhovskaya, V.A., and Krichevets, V.I., 1987, Geologic map of the U.S.S.R.: Leningrad, U.S.S.R. Ministry of Geology, scale $1: 1,000,000$ [in Russian].

Vishnevskaya, V.S., Filatova, N.I., and Dvoryankin, A.I., 1991, New data on Jurassic deposits of Semiglavaya Mountain: Akademii Nauk SSR Izvestiya, Seriya Geologicheskaya, no. 4, p. 21-30.

Vishnevskaya, V.S., Peyve, A.A., and Sokolov, S.D., 1992, Age of the Kuyul ophiolite terrane of northeastern Russian: Moscow, Akademii Nauk SSSR Doklady, v. 327, p. 364-367 [in Russian].

Vlasov, G.M., ed., 1964, Kamchatka, Kuril, and Komandorsky Islands, in Geologic descriptions, pt. 1 of Geology of the U.S.S.R., v. 31: Moscow, Nedra, 733 p. [in Russian].

-ed., 1977, Kamchatka, Kuril, and Komondorsky Islands mineral deposits, in Geology of the U.S.S.R., v. 31: Moscow, Nedra, 351 p. [in Russian].

Voevodin, V.N., Zhitkov, N.G., and Solov'ev, V.A., 1978, Mesozoic eugeosynclinal complex of Chukotsk Peninsula: Geotektonika, no. 6, p. 101-109 [in Russian].

Vogt, P.R., Taylor, P.T., Kovacs, L.C., and Johnson, G.L., 1979, Detailed aeromagnetic investigation of the Arctic Basin: Journal of Geophysical Research, v. 84, no. B, p. 1071-1090. 
Volsky, A.S., 1983, Geologic structure and history of the Upper Primorye: Leningrad, Ministry of Geology, VSEGEI, summary of Ph.D. thesis, $25 \mathrm{p}$. [in Russian].

Volynets, O.N., Antipin, V.S., Perepelov, A.B., and Anoshin, A.B., 1990, Geochemistry of the volcanic series of an island-arc system in terms of geodynamics for Kamchatka: Geologiya i Geofizika, no. 5, p. 3-13 [in Russian].

Vrublevsky, A.A., Mel'nikov, N.G., Golozubov, V.V., Shevelev, E.K., Yushmanov, Yu.P., and Isozov, L.A., 1988, Mixtites of the Sikhote-Alin fold belt: Vladivostok, U.S.S.R. Academy of Sciences, $111 \mathrm{p}$.

Walker, G.W., and MacLeod, N.S., 1991, Geologic map of Oregon: U.S. Geological Survey, 2 sheets, scale 1:500,000.

Wallace, W.K., Hanks, C.L., and Rogers, J.F., 1989, The southern Kahiltna terrane: implications for the tectonic evolution of southwestern Alaska: Geological Society of America Bulletin, v. 101, p. 1389-1407.

Watson, B.R., and Fujita, Kazuya, 1985, Tectonic evolution of Kamchatka and the Sea of Okhotsk and implications for the Pacific Basin, in Howell, D.G., ed., Tectonostratigraphic terranes of the Circum-Pacific region (Earth Science Series, v. 1): Houston, Tex., Circum-Pacific Council for Energy and Mineral Resources, p. 333-348.

Wells, R.E., 1990, Paleomagnetic rotations and the Cenozoic tectonics of the Cascade Arc, Washington, Oregon, and California: Journal of Geophysical Research v. 95, no. B, p. 19409-19417.

Wells, R.E., Engebretson, D.C., Snavely, P.D., Jr. and Coe, R.S., 1984, Cenozoic plate motions and the volcano-tectonic evolution of western Oregon and Washington: Tectonics, v. 3, p. 275-294.

Wells, R.E., and Heller, P.L., 1988, The relative contribution of accretion, shear, and extension to Cenozoic tectonic rotations in the Pacific Northwest: Geological Society of America Bulletin, v. 100, p. 325-338.

Wells, R.E., Simpson, R.W., Bentley, R.D., Beeson, M.H., Mangan, M.T., and Wright, T.L., 1989, Correlation of Miocene flows of the Columbia River Basalt Group from the central Columbia River Plateau to the coast of Oregon and Washington, in Reidel, S.P. and Hooper, P.R., eds., Volcanism and tectonism in the Columbia River flood-basalt province: Geological Society of America Special Paper 239, p. 113-128.

Wernicke, B., and Klepacki, D., 1988, Escape hypothesis for the Stikine block: Geology, v. 16, p. 461-444.

Westgate, J.A., Stemper, V.A., and Péwé, T.R., 1990, A 3-m.y. record of Pliocene-Pleistocene loess in interior Alaska: Geology, v. 18, p. 858-861.

Wheeler, J.0., Brookfield, A.J., Monger, J.W.H., Tipper, H.W., and Woodsworth, J.0., 1991, Terrane map of the Canadian Cordillera: Geological Survey of Canada Map 1731A, 2 sheets, scale $1: 2,000,000$.

Wheeler, J.O., and Gabrielse, H., 1972, The Cordilleran structural province, in Price, R.A., and Douglas, R.J.W., eds., Variations in tectonic styles in Canada: Geological Association of Canada Special Paper 2, p. 2-81.

Wheeler, J.0., and McFeely, P., 1991, Tectonic assemblage map of the Canadian Cordillera and adjacent parts of the United States of America: Geological Survey of Canada Map 1712A, scale $1: 2,000,000$.

Wilson, J.T., 1968, Static or mobile earth; the current scientific revolution: American Philosophical Society Proceedings, v. 112, no. 5, p. 309-320.

Wittbrodt, P.R., 1985, Paleomagnetism and petrology of St. Matthew Island, Bering Sea, Alaska: Fairbanks, University of Alaska, M.S. thesis, $210 \mathrm{p}$.
Wittbrodt, P.R., Stone, D.B., and Turner, D.L., 1989, Paleomagnetism and geochronology of St. Matthew Island, Bering Sea: Canadian Journal of Earth Sciences, v. 26, p. 2116-2129.

Witte, W.K., Jr., 1982, Paleomagnetism and paleogeography of Cretaceous northern Alaska: Fairbanks, University of Alaska, M.S. thesis, $146 \mathrm{p}$.

Witte, W.L, Stone, D.B., and Mull, G.C., 1987, Paleomagnetism, paleobotany, and paleogeography of the Cretaceous arctic slopes, in Tailleur, I.L., and Weimer, Paul, eds., Alaskan North Slope geology: Los Angeles, Society of Economic Paleontologists and Mineralogists, Pacific Section, and Alaska Geological Society, v. 50, p. 771-780.

Woodsworth, G.J., Anderson, R.G., and Armstrong, R.L., 1992, Plutonic regimes, in Gabrielse, H., and Yorath, C.J., eds., Geology of the Cordilleran orogen, Canada (The Geology of North America, v. G-2): Boulder, Colo., Geological Society of America, p. 493-631.

Worall, D.M., Kruglyak, V., Kunst, F., and Kuznetsov, V., 1996, Tertiary tectonics of the Sea of Okhotsk, Russia; far-field effects of the India-Eurasia collision: Tectonics, v. 15, no. 4, p. 813-826.

Wynne, P.J., Irving, E., Maxon, J.A., and Kleinspehn, K.L., 1993, Paleomagnetic results from the middle Cretaceous Silverquick and Powell Creek Formations and northward displacement of the western Intermontane Belt, British Columbia [abs.]: Geological Association of Canada Program with Abstracts, p. A-112.

1995, Paleomagnetism of the Upper Cretaceous strata of Mount Tatlow; evidence for $3000 \mathrm{~km}$ of northward displacement of the eastern Coast Belt, British Columbia: Journal of Geophysical Research, v. 100, no. B, p. 6073-6091.

Yole, R.W., 1969, Upper Paleozoic stratigraphy of Vancouver Island: Geological Association of Canada Proceedings, v. 20, p. 30-40.

Yole, R.W., and Irving, E., 1980, Displacement of Vancouver Island; paleomagnetic evidence from the Karmutsen Formation: Canadian Journal of Earth Sciences, v. 17, p. 1210-1288.

Yurkova, R.M., 1991, Mineral alterations of ophiolitic and hosting volcano-sedimentary units of the northwestern Pacific margin: Moscow, Nauka, 164 p. [in Russian].

Yushmanov, Yu.P., 1986, Synsedimentary tectonic nappes of the East Sikhote-Alin Pribrezhnay zone in the Dalnegorsk ore region: Tikhookeanskaya Geologiya, v. 3, p. 99-107 [in Russian].

Zablotsky, E.M., Kalachova, E.D., Okuneva, T.M., Sei, I.I., and Tikhomirova, L.B., 1990, New data on stratigraphy of Triassic and Jurassic deposits of the Gorinsk synclinorium [abs.], in Precambrian and Phanerozoic stratigraphy of the Transbaikal region and the southern Far East: U.S.S.R. Academy of Sciences' Far East Regional Interdepartment Stratigraphic Meeting, 14th, Khabarovsk, Abstracts, p. 148-151 [in Russian].

Zagruzina, I.A., 1977, Geochronology of Mesozoic granitoids in the northeastern U.S.S.R.: Moscow, Nauka, 279 p. [in Russian].

Zakharov, V.A., II'yna, V.I., Meledina, S.V., Nakhyaeva, T.I., and Shurygin, B.N., 1984, The Jurassic system; the Phanerozoic of Siberia, the Mesozoic and Cenozoic: Novosibirsk, Nauka, p. 16-53 [in Russian].

Zhizhina, M.S., 1959, Age of Paleozoic deposits on the Kotel'nyi Island (Geologic Series, no. 4): Academy of Sciences of the USSR Izvestiya, p. 90-91 [in Russian].

Zhulanova, I.L., 1990, The Earth's crust of northeastern Asia in the Precambrian and Phanerozoic: Moscow, Nauka, 304 p. [in Russian].

Zhulanova, I.L., and Pertzev, A.N., 1987, Basalt of the northern part of the Pekul'ney Ridge; geology, petrologic characteristics, 
and problems of genesis: Tikhookeanskaya Geologiya, no. 3, p. 65-76 [in Russian].

Zinkevich, V.P., 1981, Formations and stages of tectonic development of the northern Koryak Highland: Moscow, Nauka, 108 p. [in Russian].

Zinkevich, V.P., Konstantinovskaya, E.A., Magakyan, R.G., and Tsukanov, N.V., 1990, Accretionary structure of eastern Kamchatka: U.S.S.R. Academy of Sciences Doklady, no. 5, p. 1186-1190 [in Russian].

Zinkevich, V.P., Konstantinovskaya, E.A., Tsukanov, N.V., and Rikhter, A.V., 1993, Accretionary tectonics of Eastern Kamchatka: Moscow, Nauka, 272 p. [in Russian].

Zinkevich, V.P., and Tsukanov, N.V., 1992, The formation of the accretional structure of Eastern Kamchatka in the late Mesozoic and early Cenozoic: Geotectonics, v. 26, p. 332-343.

1993, Accretionary tectonics of Kamchatka: International Geology Review, v. 35, p. 953-973.

Zmievskiy, Yu.P., Petukhov, A.D., and Kir'yanova, V.V., 1990, New data on the structure and age of the Dzhelon suite, in Stratigraphy of the Precambrian and Phanerozoic in Transbaikal and the southern Far East: Khabarovsk, U.S.S.R. Academy of Sciences, p. 179-180 [in Russian].

Zonenshain, L.P., Kuz'min, M.I., and Natapov, L.M., 1990, Geology of the USSR; a plate tectonic synthesis (Geodynamics Series, v. 21): Washington, D.C., American Geophysical Union, 242 p.

Zyabrev, S.V., 1984, Upper Mesozoic turbidites of the southern West Sakhalin trough: Tikhookeanskaya Geologiya, no. 5, p. 22-33 [in Russian]. 
TABLES 1-3 


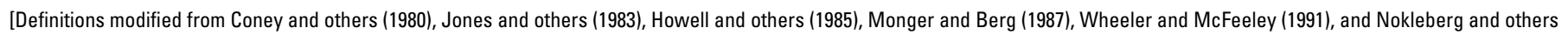
$(1994,1997 a, b)$. Note that the terms "tectonostratigraphic terrane," "accretion," and "overlap assemblage" are also defined in the text in the subsection entitled "Key Terms for Tectonic Analysis of the Circum-North Pacific"]

\section{Term}

Accretion

Accretionary-wedge and subduction-zone terrane.

\section{Definition}

Tectonic juxtaposition of two or more terranes, or tectonic juxtaposition of terranes to a cratonal margin. Accretion of terranes to one another or to a cratonal margin also defines a major change in the tectonic evolution of terranes and cratonal margins.

Fragment of a mildly to intensely deformed complex consisting of varying amounts of turbidite deposits, continental-margin rocks, oceanic crust and overlying units, and oceanic mantle. Divided into units composed predominantly of turbidite deposits or predominantly of oceanic rocks. Units are interpreted to have formed during tectonical juxtaposition in a zone of major thrusting of one lithospheric plate beneath another, generally in zones of thrusting along the margin of a continent or an island arc. May include large fault-bounded units with a coherent stratigraphy. Many subductionzone terranes contain fragments of oceanic crust and associated rocks that exhibit a complex structural history, occur in a major thrust zone, and possess blueschist-facies metamorphism.

Basinal deposits ---------------- An assemblage of sedimentary and lesser volcaniclastic and volcanic rocks that were deposited onto a single terrane after accretion, or onto a cratonal margin or craton after a major orogenic event. Includes some foreland and successor basin deposits and forearc, intra-arc, and backarc deposits.

Collage of terranes ------------- Groups of tectonostratigraphic terranes, generally in oceanic areas, for which insufficient data exist to separate units.

Craton

Chiefly regionally metamorphosed and deformed shield assemblages of Archean and Early Proterozoic sedimentary, volcanic, and plutonic rocks and overlying platform successions of Late Proterozoic, Paleozoic, and local Mesozoic and Cenozoic sedimentary and lesser volcanic rocks.

Cratonal (continental) margin.

Chiefly Late Proterozoic through Jurassic sedimentary rocks deposited on a continental shelf or slope. Consists mainly of platform units. Locally has, or may have had, an Archean and Early Proterozoic cratonal basement.

Cratonal terrane

Fragment of a craton.

Continental-margin arc terrane.

Fragment of an igneous belt of coeval plutonic and volcanic rocks and associated sedimentary rocks that formed above a subduction zone dipping beneath a continent. Inferred to possess a sialic basement.

Foreland basin Trough or depression filled with clastic deposits that were deposited adjacent to an orogenic belt.

Island-arc terrane

Fragment of an igneous belt of plutonic rocks, coeval volcanic rocks, and associated sedimentary rocks that formed above an oceanic subduction zone. Inferred to possess a simatic basement.

Metamorphic terrane-

Fragment of a highly metamorphosed or deformed assemblage of sedimentary, volcanic, or plutonic rocks that cannot be assigned to a single tectonic environment because the original stratigraphy and structure are obscured. Includes intensely deformed structural melanges that contain intensely deformed fragments of two or more terranes.

Metamorphosed continental-margin terrane.

Oceanic crust, seamount, and ophiolite terrane.

Fragment of a passive continental margin, in places moderately to highly metamorphosed and deformed, that cannot be linked with certainty to the nearby craton margin. May be derived either from a nearby cratonal margin or from a distant site.

Fragment of part or all of a suite of deep-marine sedimentary rocks, pillow basalt, gabbro, and ultramafic rocks (former eugeoclinal suite) that are interpreted as oceanic sedimentary and volcanic rocks and the upper mantle. Includes both inferred offshore oceanic and marginal ocean-basin rocks, minor volcaniclastic rocks of magmatic-arc derivation, and major marine volcanic accumulations formed at a hotspot, fracture zone, or spreading axis.

Overlap assemblage-

A postaccretionary unit of sedimentary or igneous rocks deposited on, or intruded into, two or more adjacent terranes.

Passive-continental-margin terrane.

Fragment of a cratonal margin. Postaccretionary rock unit------ Suite of sedimentary, volcanic, or plutonic rocks that formed in the late history of a terrane, after
accretion. May also occur on adjacent terranes or on the cratonal margin, either as an overlap assemblage or as basinal deposits. A relative-time term denoting rocks formed after tectonic juxtaposition of one terrane to an adjacent terrane. 
Table 1. Definitions of tectonic terms-Continued.

\section{Term}

\section{Definition}

Preaccretionary rock unit------

Suite of sedimentary, volcanic, or plutonic rocks that formed in the early history of a terrane, before accretion. Constitutes the stratigraphy and igneous geology inherent to a terrane. A relative-time term denoting rocks formed before tectonic juxtaposition of one terrane to an adjacent terrane.

Seamount and oceanic plateau.

Major marine volcanic accumulations generally formed at a hotspot, fracture zone, or spreading axis.

Subterrane

Fault-bounded unit within a terrane that exhibits a similar, but not identical, geologic history relative to another fault-bounded unit in the same terrane.

Superterrane

An aggregate of terranes that is interpreted to share either a similar stratigraphic kindred or affinity, or a common geologic history after accretion (Moore, 1992). An approximate synonym is composite terrane (Plafker and Berg, 1994).

Tectonostratigraphic terrane.

A fault-bounded geologic entity or fragment that is characterized by a distinctive geologic history which differs markedly from that of adjacent terranes (Jones and others, 1983; Howell and others, 1985).

Turbidite-basin terrane-
Fragment of a basin filled with deep-marine clastic deposits in either an orogenic forearc or backarc setting. May include continental-slope and continental-rise turbidite deposits, and submarine-fan turbidite deposits deposited on oceanic crust. May include minor epiclastic and volcaniclastic deposits. 


\begin{tabular}{|c|c|c|}
\hline \multicolumn{3}{|c|}{$\begin{array}{c}\text { CRATONAL, PASSIVE-CONTINENTAL-MARGIN, AND RELATED TERRANES AND OVERLAP } \\
\text { ASSEMBLAGES IN THE RUSSIAN SOUTHEAST }\end{array}$} \\
\hline Correlations unit(s)—age & Tectonic environment(s) & Tectonic linkages and comments \\
\hline $\begin{array}{l}\text { Kabarga, Sergeevka, Kabarga, and } \\
\text { Voznesenka terranes of the Khanka } \\
\text { superterrane-late Proterozoic and } \\
\text { Paleozoic. }\end{array}$ & Passive continental margin. & $\begin{array}{l}\text { Derived from the Gondwanaland } \\
\text { supercontinent during Devonian } \\
\text { rifting and formation of bimodal } \\
\text { volcanic rocks; contain Late } \\
\text { Paleozoic continental-margin arcs. }\end{array}$ \\
\hline $\begin{array}{l}\text { Argun and Gonzha terranes - Archean and } \\
\text { Paleozoic. }\end{array}$ & Cratonal. & $\begin{array}{l}\text { Derived from the North Asian Craton } \\
\text { during Late Proterozoic rifting; } \\
\text { dismembered parts of the Altaid } \\
\text { orogenic system. }\end{array}$ \\
\hline $\begin{array}{l}\text { Oldoi and Mamyn terranes - Proterozoic to } \\
\text { middle Paleozoic. }\end{array}$ & Passive continental margin. & $\begin{array}{l}\text { Derived from the North Asian cratonal } \\
\text { margin during Late Proterozoic } \\
\text { rifting; a dismembered part of the } \\
\text { Altaid orogenic system. }\end{array}$ \\
\hline $\begin{array}{l}\text { Baladek terrane-Archean, Paleozoic, and } \\
\text { Early Mesozoic. }\end{array}$ & Cratonal. & $\begin{array}{l}\text { Derived from the North Asian Craton } \\
\text { during Late Proterozoic rifting. }\end{array}$ \\
\hline Ayansk terrane-Paleozoic & Passive continental margin. & $\begin{array}{l}\text { Derived from the North Asian cratonal } \\
\text { margin during Late Devonian } \\
\text { rifting(?). }\end{array}$ \\
\hline Bureya terrane - early Paleozoic and older. & Continental-margin arc. & $\begin{array}{l}\text { Rifted fragment of the North China } \\
\text { Craton; a dismembered part of the } \\
\text { Manchurid orogenic system. }\end{array}$ \\
\hline \multicolumn{3}{|c|}{ LAOELIN-GRODEKOVO ISLAND ARC IN THE RUSSIAN SOUTHEAST } \\
\hline $\begin{array}{l}\text { Laoelin-Grodekovsk terrane, various backarc } \\
\text { units within the Khanka superterrane, and } \\
\text { the Chongjin terrane (Japan)-Permian. }\end{array}$ & Island arc. & $\begin{array}{l}\text { Formed adjacent to the Khanka } \\
\text { superterrane. }\end{array}$ \\
\hline $\begin{array}{l}\text { Spassk terrane of the Khanka } \\
\text { superterrane-early and middle Paleozoic. }\end{array}$ & Accretionary wedge. & $\begin{array}{l}\text { Linked to the Laoelin-Grodekovo } \\
\text { terrane. }\end{array}$ \\
\hline \multicolumn{3}{|c|}{$\begin{array}{l}\text { CRATONAL AND PASSIVE AND METAMORPHOSED CONTINENTAL-MARGIN TERRANES IN } \\
\text { THE RUSSIAN NORTHEAST, ALASKA, AND THE CANADIAN CORDILLERA }\end{array}$} \\
\hline $\begin{array}{l}\text { Chukotka terrane, the Arctic Alaska } \\
\text { superterrane, and the Cassiar } \\
\text { terrane-Proterozoic, Paleozoic, and early } \\
\text { Mesozoic. }\end{array}$ & Passive continental margin. & $\begin{array}{l}\text { Dismembered parts of the North } \\
\text { American cratonal margin. }\end{array}$ \\
\hline $\begin{array}{l}\text { Seward (both sides of the Bering Strait), } \\
\text { Coldfoot, and Ruby terranes - early and } \\
\text { middle Paleozoic (mainly). }\end{array}$ & $\begin{array}{l}\text { Metamorphosed continental } \\
\text { margin. }\end{array}$ & $\begin{array}{l}\text { Highly metamorphosed and deformed } \\
\text { fragments of North American } \\
\text { Craton Margin. Contain Late } \\
\text { Devonian and Early Mississippian } \\
\text { continental-margin-arc rocks. }\end{array}$ \\
\hline $\begin{array}{l}\text { Yukon-Tanana and Kootenay } \\
\text { terranes -Paleozoic. }\end{array}$ & $\begin{array}{l}\text { Metamorphosed continental } \\
\text { margin. }\end{array}$ & $\begin{array}{l}\text { Highly metamorphosed and deformed } \\
\text { rifted fragments of North American } \\
\text { cratonal margin; contain Late } \\
\text { Devonian and Early Mississippian } \\
\text { continental-margin-arc rocks. }\end{array}$ \\
\hline $\begin{array}{l}\text { Dillinger, Kula-Nera, Nixon Fork, Prikolyma, } \\
\text { Omulevka, Mystic, and Viliga } \\
\text { terranes-Paleozoic and early Mesozoic. }\end{array}$ & Passive continental margin. & $\begin{array}{l}\text { Dismembered fragments of the North } \\
\text { Asian cratonal margin } \\
\text { (Verkhoyansk fold-and-thrust belt); } \\
\text { Late Devonian and Early } \\
\text { Mississippian rifting. }\end{array}$ \\
\hline $\begin{array}{l}\text { Kilbuck-Idono, Okhotsk, and Omolon } \\
\text { terranes-late Archean, Proterozoic, and } \\
\text { early Paleozoic. }\end{array}$ & Cratonal. & $\begin{array}{l}\text { Dismembered fragment of the North } \\
\text { Asian Craton; Late Devonian and } \\
\text { Early Mississippian rifting. }\end{array}$ \\
\hline
\end{tabular}




\section{MAINLY TRIASSIC TO MID-CRETACEOUS ISLAND-ARC AND CONTINENTAL-MARGIN-ARC TERRANES AND OVERLAP ASSEMBLAGES AND LINKED SUBDUCTION-ZONE TERRANES}

\begin{tabular}{ccc}
\hline \multicolumn{3}{c}{ Monakin Continental-Margin Arc } \\
\hline $\begin{array}{c}\text { Monakin volcanic-plutonic belt, granitic } \\
\text { plutonic rocks of Korea, and the volcanic- }\end{array}$ & Igneous overlap assemblage. & Discontinuous parts of the Great \\
Hinggan arc.
\end{tabular}

plutonic belt of southeasternChina-Jurassic.

Badzhal, Khabarovsk, and Samarka terranes Accretionary wedge. (also the Taukha and Oshima terranes)-Paleozoic to Cretaceous.

Linked to the Monakin continentalmargin arc and the Umlekan arc (see below); remnants of subduction of the ancestral Pacific Ocean plate. The Taukha and Oshima terranes are linked to coeval granitic plutonic rocks of Korea and the volcanicplutonic belt of southeasternChina.

\begin{tabular}{lc}
\hline & Umlekan continental-margin arc \\
\hline Umlekan-Ogodzhin volcanic-plutonic & Igneous overlap assemblage. \\
belt-Jurassic and Early Cretaceous. & \\
Badzhal, Khabarovsk (older Juras sic part), & Accretionary wedge. \\
and Samarka terranes - Paleozoic to & \\
Cretaceous. &
\end{tabular}
Northward extension of the Monakin arc.

Linked to the Umelkan arc and the Monakin arc (above); remnants of subduction of the ancestral Pacific Ocean plate.

\begin{tabular}{|c|c|c|}
\hline \multicolumn{3}{|c|}{ Khingan continental-margin arc } \\
\hline $\begin{array}{l}\text { Khingan-Okhotsk volcanic-plutonic } \\
\text { belt-Early Cretaceous and mid- } \\
\text { Cretaceous. }\end{array}$ & Continental-margin arc. & $\begin{array}{l}\text { Formed after the collision of the Anui } \\
\text { microcontinent with the Samarka } \\
\text { terrane. }\end{array}$ \\
\hline $\begin{array}{l}\text { Amur River, Khabarovsk, and Kiselevka- } \\
\text { Manoma terranes-Jurassic and Early } \\
\text { Cretaceous. }\end{array}$ & Accretionary wedge. & $\begin{array}{l}\text { Linked to the Khingan continental- } \\
\text { margin arc; remnants of oblique } \\
\text { subduction of the ancestral Pacific } \\
\text { Ocean plate. }\end{array}$ \\
\hline \multicolumn{3}{|c|}{ Kema continental-margin arc } \\
\hline $\begin{array}{l}\text { Kema terrane and Early Cretaceous to mid- } \\
\text { Cretaceous volcanic rocks of Hokkaido } \\
\text { Island-mid-Cretaceous. }\end{array}$ & Igneous overlap assemblage. & $\begin{array}{l}\text { Transpressive continental-margin arc } \\
\text { analogus to the Tertiary margin of } \\
\text { California. }\end{array}$ \\
\hline $\begin{array}{l}\text { Aniva and Kamuikotan } \\
\text { terranes-Cretaceous. }\end{array}$ & Transpressional subduction zone. & $\begin{array}{l}\text { Linked to the Kema arc; remnants of } \\
\text { subduction of the ancestral Pacific } \\
\text { Ocean plate. }\end{array}$ \\
\hline \multicolumn{3}{|c|}{ Uda continental-margin arc } \\
\hline $\begin{array}{l}\text { Uda volcanic-plutonic belt, the Uniya-Bom } \\
\text { turbidite-basin terrane, the Umlekan- } \\
\text { Ogodzhin volcanic-plutonic belt, and the } \\
\text { Upper Amur sedimentary } \\
\text { assemblage-Late Jurassic and Early } \\
\text { Cretaceous. }\end{array}$ & Igneous overlap assemblage. & $\begin{array}{l}\text { Deposited on and adjacent to, and } \\
\text { intruded into, the North Asian } \\
\text { Craton and the Stanovoy block of } \\
\text { the North Asian Craton. }\end{array}$ \\
\hline $\begin{array}{l}\text { Turkuringra-Dzhagdi, Galam, and Ulban } \\
\text { terranes-Jurassic and Cretaceous. }\end{array}$ & $\begin{array}{l}\text { Subduction zone or accretionary } \\
\text { wedge. }\end{array}$ & $\begin{array}{l}\text { Linked to the Uda arc; remnants of } \\
\text { subduction of the Mongol-Okhotsk } \\
\text { Ocean plate. }\end{array}$ \\
\hline \multicolumn{3}{|c|}{ Kony-Murgal island arc } \\
\hline $\begin{array}{l}\text { Kony-Murgal terrane-Late Triassic to Early } \\
\text { Cretaceous. }\end{array}$ & $\begin{array}{l}\text { Continental-margin and island } \\
\text { arc. }\end{array}$ & $\overline{---}$ \\
\hline $\begin{array}{l}\text { Talovskiy and Penzhina-Anadyr } \\
\text { terranes - mainly Jurassic and Early } \\
\text { Cretaceous. }\end{array}$ & $\begin{array}{l}\text { Subduction zone and } \\
\text { accretionary wedge. }\end{array}$ & $\begin{array}{l}\text { Linked to the Kony-Murgal arc; } \\
\text { remnants of subduction of the } \\
\text { ancestral Pacific Ocean plate. }\end{array}$ \\
\hline \multicolumn{3}{|c|}{ Pekul'ney island arc } \\
\hline $\begin{array}{l}\text { West Pekul'ney terrane-Late Triassic to } \\
\text { Early Cretaceous. }\end{array}$ & Island arc. & $\overline{---}$ \\
\hline $\begin{array}{l}\text { Pekul'ney terrane-mainly Jurassic and Early } \\
\text { Cretaceous. }\end{array}$ & Subduction zone. & $\begin{array}{l}\text { Linked to the Pekul'ney arc; remnants } \\
\text { of subduction of the ancestral Pacific } \\
\text { Ocean plate. }\end{array}$ \\
\hline
\end{tabular}

Tables 1-3 
Table 2. Summary of correlations and tectonic linkages for the Circum-North Pacific-Continued.

\begin{tabular}{|c|c|c|}
\hline \multicolumn{3}{|c|}{ Mainitskiy island arc } \\
\hline $\begin{array}{l}\text { Mainitskiy terrane-Late Jurassic to mid- } \\
\text { Cretaceous. }\end{array}$ & Island arc. & Axial part of arc. \\
\hline Alkatvaam-Late Triassic to Paleocene. & Accretionary wedge. & $\begin{array}{l}\text { Linked to the Mainitskiy arc; remnants } \\
\text { of subduction of the ancestral Pacific } \\
\text { Ocean plate. }\end{array}$ \\
\hline \multicolumn{3}{|c|}{ Uyandina island arc } \\
\hline $\begin{array}{l}\text { Uyandina-Yasachnaya volcanic belt-Late } \\
\text { Jurassic. }\end{array}$ & Island arc. & Axial part of arc. \\
\hline $\begin{array}{l}\text { Garbyn'ya, Debin, and Chursky Range } \\
\text { ophiolites - unknown. }\end{array}$ & Ophiolite. & $\begin{array}{l}\text { Linked to the Uyandina arc; remnants } \\
\text { of subduction of the Oimyakon } \\
\text { Ocean plate. }\end{array}$ \\
\hline \multicolumn{3}{|c|}{ Oloy and Svyatov Nos continental-margin arcs } \\
\hline $\begin{array}{l}\text { Oloy and Svyatov Nos volcanic belts - Late } \\
\text { Jurassic. }\end{array}$ & Continental-margin arc. & Axial part of arc. \\
\hline $\begin{array}{l}\text { South Anyui terrane-Late Jurassic and } \\
\text { Early Cretaceous. }\end{array}$ & Subduction zone. & $\begin{array}{l}\text { Linked to the Oloy and Svyatov Nos } \\
\text { arcs; remnants of subduction of the } \\
\text { South Anyui Ocean plate. }\end{array}$ \\
\hline \multicolumn{3}{|c|}{ Alazeya island arc } \\
\hline $\begin{array}{l}\text { Alazeya, Khetachan, and Oloy } \\
\text { terranes - late Paleozoic to Early } \\
\text { Jurassic. }\end{array}$ & Island arc. & Axial part of arc. \\
\hline $\begin{array}{l}\text { Aluchin terrane-Late Paleozoic to } \\
\text { Early Jurassic. }\end{array}$ & Subduction zone & $\begin{array}{l}\text { Linked to the Alazeya arc; rem- } \\
\text { nant of subduction of the } \\
\text { ancestral Pacific Ocean plate. }\end{array}$ \\
\hline \multicolumn{3}{|c|}{ Nutesyn continental-margin arc } \\
\hline $\begin{array}{l}\text { Nutesyn terranes - mainly Late Jurassic to } \\
\text { Early Cretaceous. }\end{array}$ & Continental-margin arc & Axial part of arc. \\
\hline Velmay terrane-Upper Triassic. & Subduction zone. & $\begin{array}{l}\text { Linked to the Nutesyn arc; remnant of } \\
\text { subduction of the Angayucham } \\
\text { Ocean plate. }\end{array}$ \\
\hline \multicolumn{3}{|c|}{ Koyukuk island arc } \\
\hline $\begin{array}{l}\text { Koyukuk, Nyac, and Togiak ter ranes-mainly } \\
\text { Late Jurassic to Early Cretaceous. }\end{array}$ & Island arc. & Axial part of arc. \\
\hline $\begin{array}{l}\text { Angayucham and Goodnews ter- } \\
\text { ranes - Devonian to Early Jurassic. }\end{array}$ & Subduction zone. & $\begin{array}{l}\text { Linked to the Koyukuk arc; remnant of } \\
\text { subduction of the Angayucham } \\
\text { Ocean plate. }\end{array}$ \\
\hline \multicolumn{3}{|c|}{ Gravina island arc } \\
\hline $\begin{array}{l}\text { Kahiltna sedimentary and volcanic } \\
\text { assemblage; the Gravina-Nutzotin- } \\
\text { Gambier volcanic-plutonic-sedimentary } \\
\text { belt; the Cadwaller, Methow, Izee, and } \\
\text { Wallowa island-arc and turbidite-basin } \\
\text { terranes; the Spences Bridge volcanic- } \\
\text { plutonic belt; and the Tahtsa-Three Sisters- } \\
\text { François Lake magmatic } \\
\text { assemblage-Jurassic to mid-Cretaceous, } \\
\text { with minor Triassic units. }\end{array}$ & Island arc and turbidite basin. & Axial part of arc. \\
\hline $\begin{array}{l}\text { Chugach (younger part, Valdez Group), } \\
\text { Pacific Rim, Bridge River, and Baker } \\
\text { terranes-Jurassic to Late Cretaceous. }\end{array}$ & $\begin{array}{l}\text { Accretionary wedge and } \\
\text { subduction zone. }\end{array}$ & $\begin{array}{l}\text { Linked to the Gravina arc; remnants of } \\
\text { subduction of the Cache Creek } \\
\text { Ocean plate. }\end{array}$ \\
\hline \multicolumn{3}{|c|}{ Talkeetna-Bonanza island arc } \\
\hline $\begin{array}{l}\text { Peninsular sequence of the Wrangellia } \\
\text { superterrane (Talkeetna Formation) in } \\
\text { Alaska; the Bonanza Formation and the } \\
\text { Cadwallader island-arc and Methow } \\
\text { turbidite-basin terranes in the Canadian } \\
\text { Cordillera-Late Triassic and Early } \\
\text { Jurassic. }\end{array}$ & Island arc. & Axial part of arc. \\
\hline
\end{tabular}


Table 2. Summary of correlations and tectonic linkages for the Circum-North Pacific-Continued.

Chugach (older part, blueschist and McHugh Accretionary wedge and Complex), Bridge River, and Baker terranes-Paleozoic, Triassic, and Early Jurassic. subduction zone.
Linked to the Talkeetna and Bonanza arcs. Remnants of subduction of the Cache Creek and Farallon Ocean plates.

\begin{tabular}{lcc}
\hline & Stikinia-Quesnellia island arc & \\
\hline Stikinia and Quesnellia terranes-Permian to Island arc. & Axial part of arc. \\
Early Jurassic. & & \\
Cache Creek, Slide Mountain, and & Subduction zone and & Linked to the Stikinia-Quesnellia arc; \\
Seventymile terranes - Paleozoic and & accretionary wedge. & remnants of subduction of the Cache \\
Mesozoic. & & Creek Ocean plate. \\
\hline
\end{tabular}

\section{MAINLY LATE CRETACEOUS AND EARLY CENOZOIC CONTINENTAL-MARGIN ARCS,} ISLAND ARCS, AND LINKED SUBDUCTION ZONES

East Sikhote-Alin continental-margin arc (Late Cretaceous)

\begin{tabular}{lcc}
\hline $\begin{array}{c}\text { East Sikhote-Alin volcanic-plutonic belt and } \\
\text { the Sorachi-Yezo and West Sakhalin }\end{array}$ & Igneous overlap assemblage. & Axial part of arc. \\
terrane-Cretaceous and early Tertiary. & & \\
$\begin{array}{c}\text { Hidaka accretionary-wedge and the younger } \\
\text { part of the Aniva, Nabilsky, and Tokoro }\end{array}$ & $\begin{array}{c}\text { Accretionary wedge and } \\
\text { subduction zone. }\end{array}$ & $\begin{array}{c}\text { Linked to East Sikhote-Alin arc; } \\
\text { remnants of subduction of the } \\
\text { terranes-Permian to Cretaceous. }\end{array}$ \\
\hline
\end{tabular}

\begin{tabular}{|c|c|c|}
\hline \multicolumn{3}{|c|}{ Okhotsk-Chukotka continental-margin arc } \\
\hline $\begin{array}{l}\text { Okhotsk-Chukotka volcanic-plutonic } \\
\text { belt and the Penzhina sedimentary } \\
\text { basin-Cretaceous and early Tertiary. }\end{array}$ & Igneous overlap assemblage. & Axial part of arc. \\
\hline $\begin{array}{l}\text { West-Kamchatka, Ekonay, and Yan- } \\
\text { ranay terranes-Upper Paleozoic, } \\
\text { Jurassic and Early Cretaceous. } \\
\end{array}$ & Accretionary wedge. & $\begin{array}{l}\text { Linked to Okhotsk-Chukotka arc; } \\
\text { remnants of subduction of the } \\
\text { ancestral Pacific Ocean plate. }\end{array}$ \\
\hline \multicolumn{3}{|c|}{ Olyutorka island arc } \\
\hline $\begin{array}{l}\text { Olyutorka-Kamchatka, Iruneiskiy, } \\
\text { Kronotskiy, Shmidt, Terpeniya, and } \\
\text { Nemuro terranes - Late Cretaceous and } \\
\text { Early Tertiary. }\end{array}$ & Island arc. & Axial part of arc. \\
\hline $\begin{array}{l}\text { Vetlovskiy terrane-Late Cretaceous and } \\
\text { early Tertiary. }\end{array}$ & Accretionary wedge. & $\begin{array}{l}\text { Linked to the Olyutorka arc; remnants } \\
\text { of subduction of the ancestral Pacific } \\
\text { Ocean plate. }\end{array}$ \\
\hline \multicolumn{3}{|c|}{ Kluane and Coast North Cascade continental-margin arcs } \\
\hline $\begin{array}{l}\text { Kuskokwim Mountains sedimentary, } \\
\text { volcanic, and plutonic belt, the Alaska } \\
\text { Range-Talkeetna Mountains volcanic- } \\
\text { plutonic belt, the Coast-North Cascade } \\
\text { plutonic belt, and the Kamloops magmatic } \\
\text { belt-Late Cretaceous and early Tertiary. }\end{array}$ & Igneous overlap assemblage. & Axial part of arc. \\
\hline $\begin{array}{l}\text { Chugach terrane (Late Cretaceous Valdez } \\
\text { Group), the older part of the Prince } \\
\text { William terrane, and the Pacific Rim } \\
\text { terrane-Late Cretaceous and early } \\
\text { Tertiary. }\end{array}$ & $\begin{array}{l}\text { Accretionary wedge and } \\
\text { subduction zone. }\end{array}$ & $\begin{array}{l}\text { Linked to the Kluane and Coast North } \\
\text { Cascade arcs; remnants of subduction } \\
\text { of the ancestral Pacific Ocean plate. }\end{array}$ \\
\hline
\end{tabular}

\begin{tabular}{|c|c|c|}
\hline \multicolumn{3}{|c|}{$\begin{array}{l}\text { MIDDLE AND LATE CENOZOIC CONTINENTAL-MARGIN ARCS AND } \\
\text { LINKED SUBDUCTION ZONES }\end{array}$} \\
\hline \multicolumn{3}{|c|}{ Northeast Asia continental-margin arc } \\
\hline $\begin{array}{l}\text { East Japan volcanic-plutonic belt, the Central } \\
\text { Kamchatka volcanic belt, the Central } \\
\text { Kamchatka volcanic and sedimentary } \\
\text { basin, the East Kamchatka volcanic belt, } \\
\text { the Eastern Sakhalin sedimentary basin, } \\
\text { and West Kamchatka sedimentary } \\
\text { basin-Early Eocene to Miocene to } \\
\text { present. }\end{array}$ & Igneous overlap assemblages. & Axial part of arc. \\
\hline $\begin{array}{l}\text { Kuril-Kamchatka terrane-Miocene to } \\
\text { present. }\end{array}$ & $\begin{array}{l}\text { Accretionary wedge and } \\
\text { subduction zone. }\end{array}$ & $\begin{array}{l}\text { Linked to the Northeast Asia arc; } \\
\text { remnant of subduction of the ancestral } \\
\text { Pacific Ocean plate. }\end{array}$ \\
\hline
\end{tabular}


Table 2. Summary of correlations and tectonic linkages for the Circum-North Pacific-Continued.

Sea of Japan unit, the Sakhalin-Primorye Backarc units. $\quad$ Linked to the Northeast Asia arc. volcanic belt, and the Kuril unit-Oligocene to Miocene. Aleutian-Wrangell continental-margin arc

Aleutian volcanic belt and the Wrangell Igneous overlap assemblages. Axial part of arc. volcanic field-Early Eocene to Miocene to present.

Attu Island part of the Prince William Accretionary wedge.

Linked to the Aleutian-Wrangell arc; terrane and the Yakutat terrane-Early Tertiary to present.

Cascade continental-margin arc

Cascade volcanic-plutonic belt-Eocene to Igneous overlap assemblage. present.

Siletzia, Olympic Core, and Hoh terranes and Subduction zone and modern-day subduction zone-Eocene to accretionary wedge. present.

Columbia River Basalt Group-Miocene.

Backarc unit. remnants of subduction of the ancestral Pacific Ocean plate.

Axial part of arc.
Linked to the Cascade arc; remnants of
subduction of the Juan de Fuca plate.
Linked to the Cascade arc.


Table 3. Paleomagnetic data for geologic units and geographic areas in the Russian Far East, Alaska, and the Canadian Cordillera.

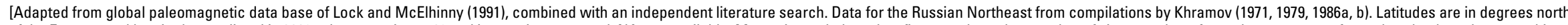
of the Equator, and longitudes are listed in $360^{\circ}$ values, starting at $0^{\circ}$ and increasing eastward. NA, not available. Map unit, symbol used on figures 1 through 4; number of sites, number of samples, or means of samples, that have been combined for a given locality; paleolatitude, ancient latitude of location determined from inclination of ancient magnetic field with respect to ancient horizontal, assuming that recorded field represents a mean axial dipole; +dl and -dl, 95-percent erro bars associated with observed scatter in data. For paleopoles, latitude and longitude are location of axis of a geocentric dipole that would produce the magnetization observed in the rocks. The 95-percent error bars, indicating scatter of data points, are represented by "a95" for circular distributions, and by the axes of an elliptical distribution, dp, dm. Paleomagnetic data are evaluated and given a grade of A (very good) to D (marginal). Do., ditto. See text for additional explanation of evaluation procedure]

\begin{tabular}{|c|c|c|c|c|c|c|c|c|c|c|c|c|c|c|}
\hline \multicolumn{15}{|c|}{ MISCELLANEOUS OVERLAP ASSEMBLAGES IN RUSSIAN FAR EAST, ALASKA, AND CANADIAN CORDILLERA } \\
\hline $\begin{array}{l}\text { Map Unit, Overlap } \\
\text { Assemblage. } \\
\text { Geographic Area. }\end{array}$ & \begin{tabular}{|l|l|} 
Rock Unit & 0 \\
\end{tabular} & Lat & Long & Age & $\begin{array}{l}\text { No. of } \\
\text { Sites }\end{array}$ & ${ }_{-\mathrm{dl}} \bar{P}$ & $\begin{array}{l}\text { olatitu } \\
\text { Lat }\end{array}$ & $+\mathrm{dl}$ & Lat & ${ }_{\text {Long }} \mathrm{Pa}$ & $\begin{array}{l}\text { leopole } \\
\text { a95, dp }\end{array}$ & a95, dm & Reference & Grade \\
\hline $\begin{array}{l}-- \text {, Aleutian-Bowers } \\
\text { sedimentary basin. } \\
\text { Amlia Island, Bering } \\
\text { Straits. }\end{array}$ & $\begin{array}{l}\text { Unnamed sedimen- } \\
\text { tary rocks. }\end{array}$ & 52.1 & 186.5 & 40 & 9 & 58.6 & 68.8 & 80.1 & 64 & 229 & 15 & NA & $\begin{array}{l}\text { Stone and others, } \\
\text { 1983; Harbert } \\
\text { and others, } \\
\text { 1984; Harbert, } \\
\text { 1987. }\end{array}$ & $\mathrm{A}$ \\
\hline $\begin{array}{l}\text { Same. } \\
\text { Umnak Island, Bering } \\
\text { Straits. }\end{array}$ & $\begin{array}{l}\text { Unnamed sedimen- } \\
\text { tary rocks. }\end{array}$ & 53 & 191 & 38 & 29 & 51.1 & 57.0 & 63.5 & 73 & 234 & 6 & NA & $\begin{array}{l}\text { Stone and others, } \\
\text { 1983; Harbert } \\
\text { and others, } \\
\text { 1984; Harbert, } \\
1987 .\end{array}$ & A \\
\hline $\begin{array}{l}--, \text { Axelgold pluton } \\
\text { intruding Cache Creek } \\
\text { terrane (CC). }\end{array}$ & Axelgold intrusion. & 56.2 & 233.9 & 125 & 67 & 45.7 & 52.5 & 60.2 & 76 & 327 & 8 & 7 & $\begin{array}{l}\text { Monger and } \\
\text { Irving, } 1980 .\end{array}$ & $\mathrm{B}$ \\
\hline $\begin{array}{l}\text { Northern British Columbia. } \\
\text { al, Aleutian volcanic belt. } \\
\text { Medny \&, Komandorski } \\
\text { Islands, Russian } \\
\text { Northeast. }\end{array}$ & $\begin{array}{l}\text { Unnamed } \\
\text { sedimentary unit. }\end{array}$ & 54.8 & 167.6 & $\begin{array}{l}\text { Paleo- } \\
\text { cene? }\end{array}$ & 40 & 37 & 43.2 & 50.6 & 41.4 & 238.1 & 8.8 & 6.9 & $\begin{array}{l}\text { Bazhenov and } \\
\text { Burtman, 1996; } \\
\text { Bazhenov and } \\
\text { others, } 1992 .\end{array}$ & A \\
\hline $\begin{array}{l}\text { at, Alaska Range-Talkeetna } \\
\text { Mountains volcanic- } \\
\text { plutonic belt. } \\
\text { Matanuska Valley }\end{array}$ & $\begin{array}{l}\text { Talkeetna } \\
\text { Volcanics. }\end{array}$ & 61.9 & 211.5 & Eocene & 28 & 68.8 & 78.1 & 88.0 & 66 & 188 & 8 & NA & $\begin{array}{l}\text { Panuska and } \\
\text { Stone, 1985a .b; } \\
\text { Panuska and } \\
\text { others, } 1990 .\end{array}$ & A \\
\hline Same. & Unnamed unit. & 61.6 & 211.7 & 42 & 14 & 52.5 & 61.8 & 72.4 & 73 & 281 & 9 & NA & $\begin{array}{l}\text { Stamatakos and } \\
\text { others, 1987, } \\
1988 .\end{array}$ & $\mathrm{C}$ \\
\hline $\begin{array}{l}\text { Same. } \\
\text { Talkeetna Mountains. }\end{array}$ & $\begin{array}{l}\text { Talkeetna } \\
\text { Volcanics. }\end{array}$ & 62.5 & 211 & $54-50$ & 25 & 61.8 & 74.3 & 88.0 & 70 & 180 & 12 & NA & $\begin{array}{c}\text { Hillhouse and } \\
\text { others, } 1985 .\end{array}$ & A \\
\hline
\end{tabular}


Table 3. Paleomagnetic data for geologic units and geographic areas in the Russian Far East, Alaska, and the Canadian Cordillera—Continued.

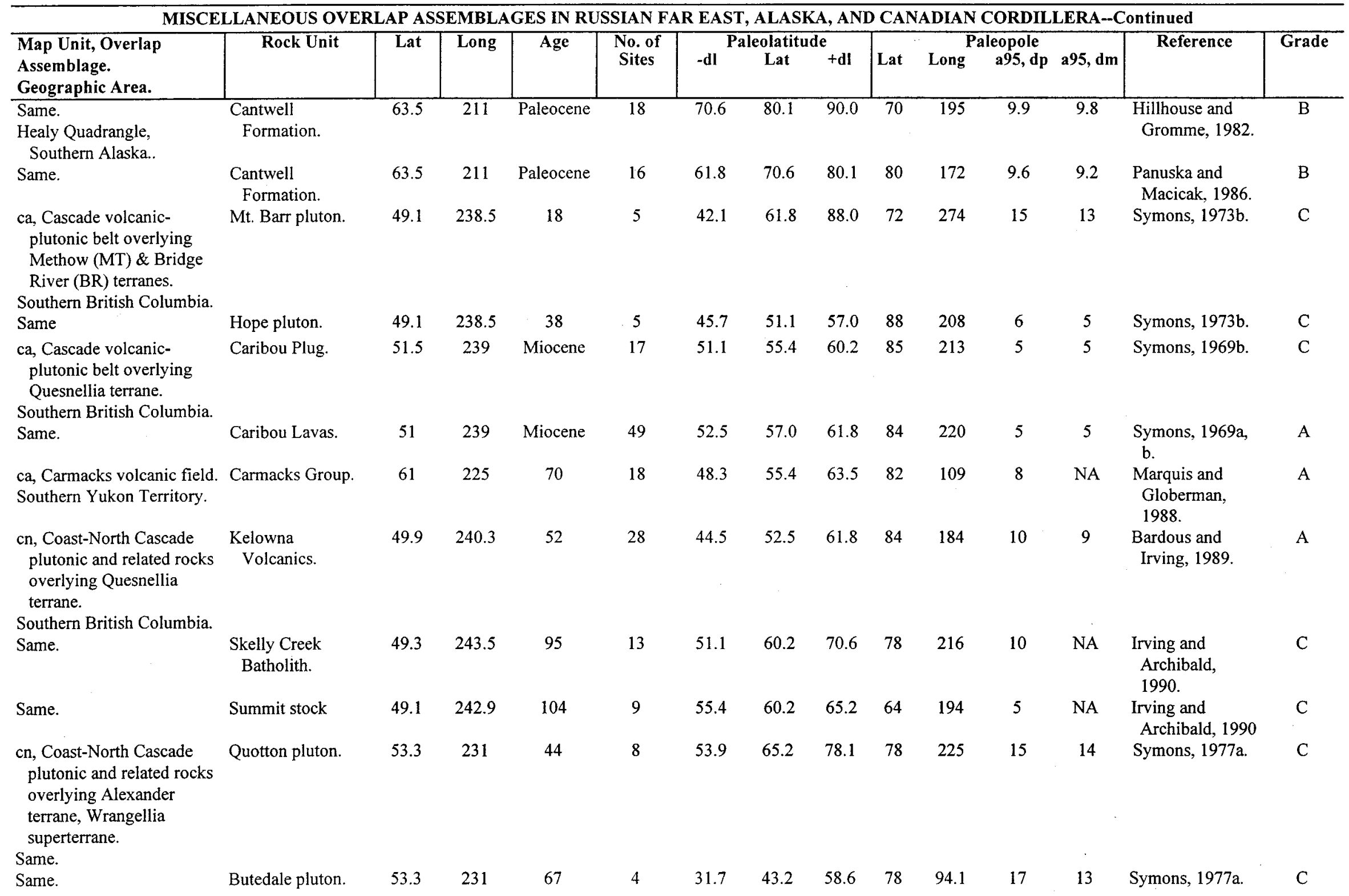


Table 3. Paleomagnetic data for geologic units and geographic areas in the Russian Far East, Alaska, and the Canadian Cordillera-Continued.

\begin{tabular}{|c|c|c|c|c|c|c|c|c|c|c|c|c|c|c|}
\hline \multicolumn{15}{|c|}{ MISCELLANEOUS OVERLAP ASSEMBLAGES IN RUSSIAN FAR EAST, ALASKA, AND CANADIAN CORDILLERA--Continued } \\
\hline $\begin{array}{l}\text { Map Unit, Overlap } \\
\text { Assemblage. } \\
\text { Geographic Area. }\end{array}$ & Rock Unit & Lat & Long & Age & $\begin{array}{l}\text { No. of } \\
\text { Sites }\end{array}$ & $-\mathrm{dl}$ & $\begin{array}{l}\text { olatitı } \\
\text { Lat }\end{array}$ & $+\mathrm{e}$ & Lat & $\begin{array}{l}\mathrm{Pa} \\
\text { Long }\end{array}$ & $\begin{array}{l}\text { eopole } \\
\text { a95, dp }\end{array}$ & a95, $\mathbf{d m}$ & Reference & Grade \\
\hline $\begin{array}{l}\text { ek, East Kamchatka } \\
\text { volcanic belt overlying } \\
\text { Kronotskiy terrane } \\
\text { (KRO). }\end{array}$ & Unnamed unit. & 54.8 & 162.1 & Eocene & $\overline{42}$ & 31 & 39.8 & 50.9 & 53.9 & 68.7 & 13.3 & 9.9 & $\begin{array}{c}\text { Bazhenov and } \\
\text { others, } 1992\end{array}$ & $\mathrm{~A}$ \\
\hline $\begin{array}{l}\text { Kamchatka Peninsula. } \\
\text { ek, East Kamchatka } \\
\text { volcanic belt overlying } \\
\text { Vetlovskiy terrane. }\end{array}$ & Unnamed unit. & 55 & 161 & Miocene & 47 & 38.7 & 47.0 & 57.0 & 75 & 47 & 11.3 & 9.1 & $\begin{array}{l}\text { Ivanov and } \\
\text { others, } 1977 .\end{array}$ & $\mathrm{D}$ \\
\hline $\begin{array}{l}\text { East Kamchatka Peninsula. } \\
\text { gg, Gravina-Nutzotin- } \\
\text { Gambier overlap } \\
\text { assemblage. }\end{array}$ & $\begin{array}{l}\text { Duke Island } \\
\text { ultramafic } \\
\text { complex. }\end{array}$ & 54.9 & 228.7 & 110 & 8 & 27.1 & 36.2 & 47.9 & 68 & 33.5 & NA & NA & $\begin{array}{l}\text { Bogue and } \\
\text { others, } 1995 .\end{array}$ & B \\
\hline $\begin{array}{l}\text { Duke Island, Southeastern } \\
\text { Alaska. }\end{array}$ & & & & & & & & & & & & & & \\
\hline $\begin{array}{l}\text { ia, Interior Alaska volcanic } \\
\text { belt. }\end{array}$ & Basalt. & 65.8 & 205 & 43 & 8 & 55.4 & 74.3 & 90 & 54 & 225 & 22 & 21 & Harris, 1985. & $\mathrm{D}$ \\
\hline $\begin{array}{l}\text { Yukon Koyukuk basin, } \\
\text { West-Central Alaska. }\end{array}$ & & & & & & & & & & & & & & \\
\hline $\begin{array}{l}\text { Same. } \\
\text { Unalakleet Quadrangle. }\end{array}$ & Basalt. & 63 & 200 & 51 & 10 & 32.6 & 57.0 & 86.0 & 53 & 263 & 35 & 13 & Harris, 1985. & $A$ \\
\hline Same. & $\begin{array}{l}\text { Felsic volcanic } \\
\text { rocks. }\end{array}$ & 63.8 & 200.7 & $51-52$ & 33 & 58.6 & 70.6 & 84.0 & 69 & 153 & 13 & 13 & Harris, 1985. & A \\
\hline $\begin{array}{l}\text { Same. } \\
\text { Yukon-Koyukuk basin. } \\
\text { West-Central Alaska. }\end{array}$ & $\begin{array}{l}\text { Eocene volcanic } \\
\text { rocks. }\end{array}$ & 65 & 203 & $55-43$ & 4 & 44.5 & 78.1 & 90 & 79 & 156 & 38 & & $\begin{array}{l}\text { Harris, 1985; } \\
\text { Harris and } \\
\text { others, } 1986 .\end{array}$ & $\mathrm{C}$ \\
\hline $\begin{array}{l}\text { ia, Interior Alaska volcanic } \\
\text { belt. }\end{array}$ & Fairbanks Basalt. & 64.8 & 211.5 & 53 & NA & 52.5 & 67.0 & 84.0 & 60 & 163 & 16.9 & 15.9 & $\begin{array}{l}\text { Roe and Stone, } \\
1993 .\end{array}$ & A \\
\hline $\begin{array}{l}\text { Yukon-Tanana Upland, } \\
\text { Interior Alaska. }\end{array}$ & & & & & & & & & & & & & & \\
\hline $\begin{array}{l}\text { ka, Kamloops volcanic belt. } \\
\text { Southern British Columbia. }\end{array}$ & Kamloops Group. & 51 & 238.7 & 49 & 24 & 48.4 & 58.6 & 70.4 & 81 & 222 & 12.3 & 11 & $\begin{array}{l}\text { Symons and } \\
\text { Wellings, } 1989 .\end{array}$ & A \\
\hline $\begin{array}{l}\text { Unnamed flows overlying } \\
\text { Kahiltna sedimentary and } \\
\text { volcanic assemblage. }\end{array}$ & $\begin{array}{l}\text { Unnamed volcanic } \\
\text { flows. }\end{array}$ & 60.3 & 205.3 & 44 & 13 & 51.1 & 61.8 & 74.3 & 60 & 149 & 12 & NA & $\begin{array}{l}\text { Thrupp and Coe, } \\
1986 .\end{array}$ & $\mathrm{A}$ \\
\hline
\end{tabular}


Table 3. Paleomagnetic data for geologic units and geographic areas in the Russian Far East, Alaska, and the Canadian Cordillera—Continued.

\begin{tabular}{|c|c|c|c|c|c|c|c|c|c|c|c|c|c|c|}
\hline \multirow{2}{*}{\begin{tabular}{l} 
MISCE] \\
\cline { 2 - 2 } \\
Assemblage. \\
Geographic Area.
\end{tabular}} & \multirow{2}{*}{$\begin{array}{l}\text { CLANEOUS OVER } \\
\text { Rock Unit }\end{array}$} & \multirow{2}{*}{$\frac{\text { AP AS }}{\text { Lat }}$} & \multirow{2}{*}{$\frac{\text { EMBLA }}{\text { Long }}$} & \multirow{2}{*}{$\frac{\text { ES IN RI }}{\text { Age }}$} & \multirow{2}{*}{$\begin{array}{l}\text { SIAN F } \\
\begin{array}{l}\text { No. of } \\
\text { Sites }\end{array}\end{array}$} & \multicolumn{3}{|c|}{$\frac{\text { EAST, ALASKA, ANI }}{\text { Paleolatitude }}$} & \multirow[b]{2}{*}{ Lat } & \multirow{2}{*}{\multicolumn{2}{|c|}{$\begin{array}{c}\text { ADIAN CORDIL] } \\
\text { Paleopole } \\
\text { Long } \quad \text { 995, dp }\end{array}$}} & \multirow[b]{2}{*}{ a95, dm } & \multirow{2}{*}{$\begin{array}{l}\text { ontinued } \\
\text { Reference }\end{array}$} & \multirow[b]{2}{*}{ Grade } \\
\hline & & & & & & ${ }_{-\mathrm{dI}} \mathrm{P}$ & $\begin{array}{l}\text { olatitt } \\
\text { Lat }\end{array}$ & $+d \mathrm{el}$ & & & & & & \\
\hline $\begin{array}{l}\mathrm{kc} \text {, Central Kamchatka } \\
\text { volcanic belt overlying } \\
\text { Olyutorka-Kamchatka } \\
\text { terrane. } \\
\text { Kamchatka Peninsula. }\end{array}$ & Unnamed unit. & 59.7 & 165 & Eocene & 105 & 48.6 & 53.9 & 59.8 & 81 & 91 & 6.5 & 5.6 & Kovalenko, 1992. & $\mathrm{~A}$ \\
\hline $\begin{array}{l}\text { Same. } \\
\text { Malinovskii area, } \\
\text { Kamchatka Peninsula. }\end{array}$ & Unnamed unit. & 60.5 & 167.5 & Eocene & 113 & 57.3 & 65.2 & 73.9 & 85 & 153 & 8.9 & 8.3 & Kovalenko, 1992 & A \\
\hline $\begin{array}{l}\text { Same. } \\
\text { Karaginskii Island, }\end{array}$ & Unnamed unit. & 59 & 164 & Eocene & 37 & 39.2 & 51.1 & 66.1 & 79 & 32 & 15.9 & 13.4 & Kovalenko, 1992. & A \\
\hline $\begin{array}{l}\text { kw, Kuskokwim Mountains } \\
\text { sedimentary, volcanic, \& } \\
\text { plutonic belt. } \\
\text { St. Matthew Island, Bering } \\
\text { Sea. }\end{array}$ & $\begin{array}{l}\text { Unnamed volcanic } \\
\text { rocks. }\end{array}$ & 60.5 & 187 & 79 & 38 & 58.6 & 67.0 & 76.2 & 80 & 235 & 10 & NA & $\begin{array}{l}\text { Wittbrodt, } 1985 \\
\text { Wittbrodt and } \\
\text { others, } 1989 .\end{array}$ & B \\
\hline $\begin{array}{l}\text { kw, Kuskokwim Mountains } \\
\text { sedimentary, volcanic, \& } \\
\text { plutonic belt overlying } \\
\text { Togiak terrane. } \\
\text { Hagemeister Island, } \\
\text { Southern Alaska. }\end{array}$ & $\begin{array}{c}\text { Bristol Bay } \\
\text { Volcanics. }\end{array}$ & 58.8 & 199.5 & 68 & 74 & 58.6 & 63.5 & 68.8 & 65 & 147 & 5 & NA & $\begin{array}{l}\text { Globerman and } \\
\text { Coe, } 1983, \text { Coe } \\
\text { and others, } \\
1985 .\end{array}$ & $A$ \\
\hline $\begin{array}{l}\text { io, Indigirka-Oloy } \\
\text { sedimentary-volcanic- } \\
\text { plutonic assemblage } \\
\text { overlying Omolon terrane. } \\
\text { Russian Northeast. }\end{array}$ & Sufoi zone & 64.5 & 155.5 & $\begin{array}{l}\text { Late } \\
\text { Jurassic }\end{array}$ & 8 & 27 & 39 & 51 & 21 & 116 & 11 & NA & $\begin{array}{l}\text { Bondenko and } \\
\text { Didenko, } 1997 .\end{array}$ & A \\
\hline $\begin{array}{l}--, \text { Volcanic rocks. } \\
\text { Porcupine River area, } \\
\text { Northwestern Alaska. }\end{array}$ & Unnamed unit & 67.2 & 218 & 16 & 17 & $\mathrm{NA}$ & 71.0 & NA & 86 & 201 & NA & NA & $\begin{array}{l}\text { Plumley and } \\
\text { Vance, } 1988 .\end{array}$ & D \\
\hline $\begin{array}{l}\text { oc, Okhotsk-Chukotka } \\
\text { volcanic-plutonic belt, } \\
\text { overlying Viliga terrane. }\end{array}$ & Unnamed unit. & 61.8 & 156 & $\begin{array}{l}\text { Creta- } \\
\text { ceous }\end{array}$ & 24 & 76.2 & 88.0 & 90.0 & 60 & 155 & 12 & 12 & $\begin{array}{l}\text { Pechersky } \\
1970 .\end{array}$ & C \\
\hline
\end{tabular}


Table 3. Paleomagnetic data for geologic units and geographic areas in the Russian Far East, Alaska, and the Canadian Cordillera—Continued.

\begin{tabular}{|c|c|c|c|c|c|c|c|c|c|c|c|c|c|c|}
\hline \multicolumn{15}{|c|}{ MISCELLANEOUS OVERLAP ASSEMBLAGES IN RUSSIAN FAR EAST, ALASKA, AND CANADIAN CORDILLERA--ContinUed } \\
\hline $\begin{array}{l}\text { Map Unit, Overlap } \\
\text { Assemblage. } \\
\text { Geographic Area. }\end{array}$ & Rock Unit & Lat & Long & Age & $\begin{array}{l}\text { No. of } \\
\text { Sites }\end{array}$ & $\overline{-d I}$ & $\begin{array}{l}\text { olatitu } \\
\text { Lat }\end{array}$ & $+\mathrm{dl}$ & Lat & $\begin{array}{l}\overline{\mathbf{P}} \\
\text { Long }\end{array}$ & $\begin{array}{l}\text { eopole } \\
\text { a95, dp }\end{array}$ & a95, dm & Reference & Grade \\
\hline $\begin{array}{l}\text { sb, Spences Bridge } \\
\text { volcanic-plutonic belt, } \\
\text { overlying Quesnellia } \\
\text { terrane. } \\
\text { Southern Canadian } \\
\text { Cordillera. }\end{array}$ & $\begin{array}{l}\text { Spences Bridge } \\
\text { Group. }\end{array}$ & 49.9 & 239 & 100 & 17 & 39.3 & 45.7 & 53.1 & 64 & 321 & 7.5 & NA & $\begin{array}{l}\text { Irving and } \\
\text { Thorkelson, } \\
1990 .\end{array}$ & A \\
\hline Same. & $\begin{array}{l}\text { Spences Bridge } \\
\text { Group and Spius } \\
\text { Volcanics. }\end{array}$ & 50 & 239 & 104 & 47 & 48.3 & 52.5 & 57 & NA & NA & NA & NA & $\begin{array}{l}\text { Irving and others, } \\
1995 .\end{array}$ & A \\
\hline
\end{tabular}

\begin{tabular}{|c|c|c|c|c|c|c|c|c|c|c|c|c|c|c|}
\hline \multicolumn{15}{|c|}{ MISCELLANEOUS LATE CRETACEOUS AND TERTIARY SEDIMENTARY AND VOLCANIC ROCKS OVERLYING WRANGELLIA SUPERTERRANE } \\
\hline $\begin{array}{l}- \text {, Volcanic and plutonic } \\
\text { units overlying or } \\
\text { intruding Alexander } \\
\text { sequence, Wrangellia } \\
\text { superterrane. }\end{array}$ & $\begin{array}{l}\text { Point Camden } \\
\text { gabbro (Kuiu- } \\
\text { Etolin belt). }\end{array}$ & 56.9 & 226.2 & 23 & 20 & 44.5 & 53.9 & 65.2 & 87 & 142 & 10 & NA & $\begin{array}{l}\text { Haeussler and } \\
\text { others, 1992a, b. }\end{array}$ & $\mathrm{C}$ \\
\hline $\begin{array}{l}\text { Keku Strait, Southeastern } \\
\text { Alaska. }\end{array}$ & & & & & & & & & & & & & & \\
\hline $\begin{array}{l}--, \text { Brothers Volcanics } \\
\text { overlying Gravina- } \\
\text { Nutzotin-Gambier overlap } \\
\text { assemblage overlying } \\
\text { Wrangellia sequence, } \\
\text { Wrangellia superterrane. } \\
\text { West Brothers Island, } \\
\text { Southeastern Alaska. }\end{array}$ & $\begin{array}{l}\text { Brothers } \\
\text { Volcanics. }\end{array}$ & 57.3 & 226.1 & 76 & 7 & 4.5 & 8.2 & 12.0 & 9 & 314 & 5 & $\mathrm{NA}$ & $\begin{array}{c}\text { Panuska and } \\
\text { others, } 1984 .\end{array}$ & B \\
\hline $\begin{array}{l}\text { ca, Cascade volcanic- } \\
\text { plutonic belt overlying or } \\
\text { intruding Wrangellia } \\
\text { sequence, Wrangellia } \\
\text { superterranc. }\end{array}$ & Flores Volcanics. & 49 & 234.5 & 51 & 12 & 43.2 & 52.5 & 63.5 & 81 & 188 & 10 & $\mathrm{NA}$ & $\begin{array}{l}\text { Irving and } \\
\text { Brandon, } 1990 .\end{array}$ & A \\
\hline $\begin{array}{l}\text { Vancouver Island, Southern } \\
\text { Canadian Cordillera. }\end{array}$ & & & & & & & & & & & & & & \\
\hline Same. & East Sooke gabbro. & 48.4 & 227.5 & Paleocene & 29 & 40.9 & 45.7 & 51.1 & 69 & 151 & 7 & 5 & Symons, 1973d. & $\mathrm{C}$ \\
\hline $\begin{array}{l}\text { Same. } \\
\text { Queen Charlotte Island, } \\
\text { Southern Canadian }\end{array}$ & Masset Formation. & 53.6 & 227.5 & Paleocene & 52 & 57.0 & 67.0 & 78.1 & 72 & 263 & 11 & NA & $\begin{array}{l}\text { Hicken and } \\
\text { Irving, } 1977 .\end{array}$ & A \\
\hline
\end{tabular}


Table 3. Paleomagnetic data for geologic units and geographic areas in the Russian Far East, Alaska, and the Canadian Cordillera—Continued.

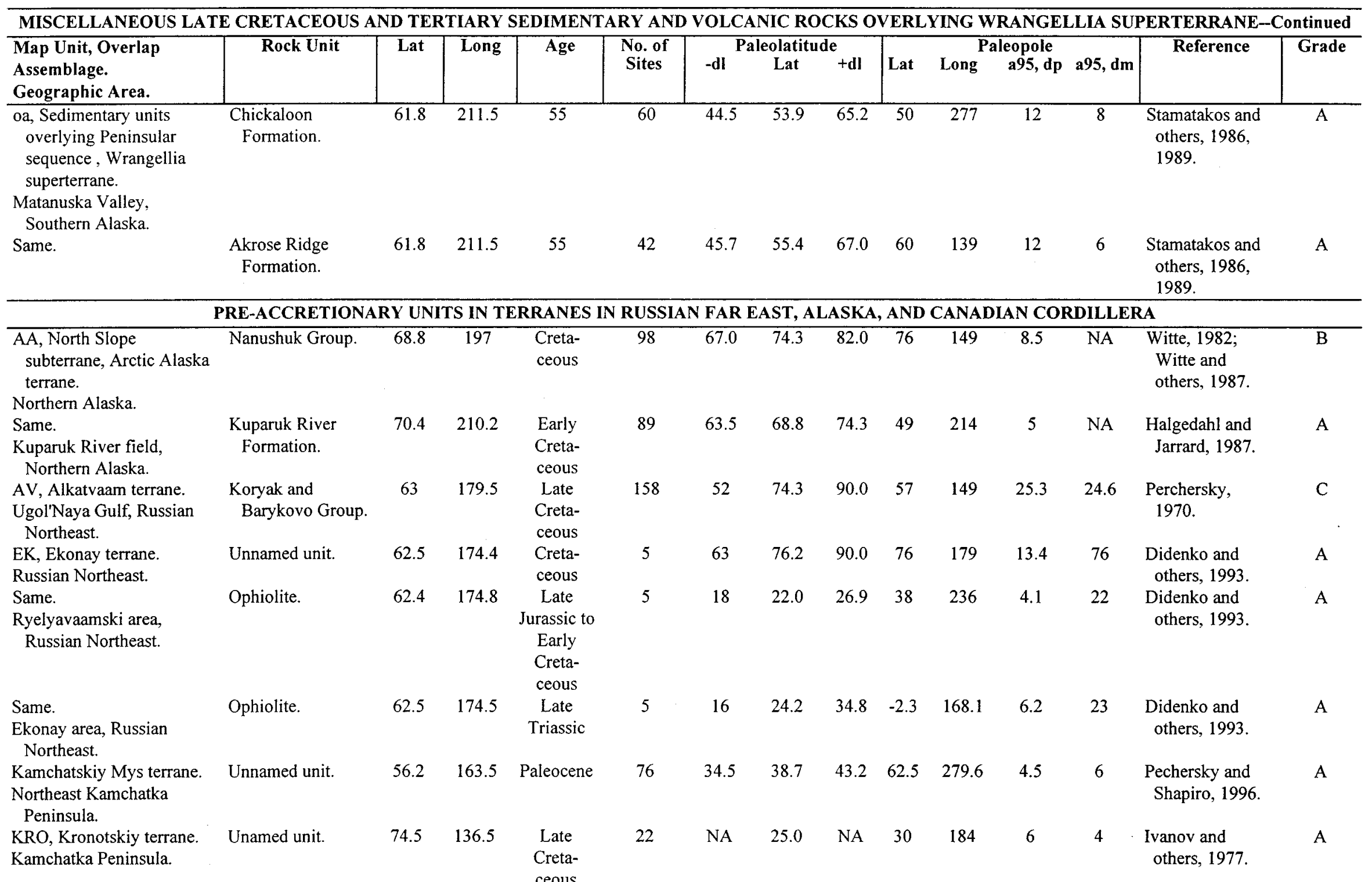


Table 3. Paleomagnetic data for geologic units and geographic areas in the Russian Far East, Alaska, and the Canadian Cordillera-Continued.

\begin{tabular}{|c|c|c|c|c|c|c|c|c|c|c|c|c|c|c|}
\hline \multicolumn{15}{|c|}{ PRE-ACCRETIONARY UNITS IN TERRANES IN RUSSIAN FAR EAST, ALASKA, AND CANADIAN CORDILLERA--COntinUEd } \\
\hline $\begin{array}{l}\text { Map Unit, Overlap } \\
\text { Assemblage. } \\
\text { Geographic Area. }\end{array}$ & Rock Unit & Lat & Long & Age & $\begin{array}{l}\text { No. of } \\
\text { Sites }\end{array}$ & ${ }_{-d l}^{P}$ & $\begin{array}{c}\text { eolatitu } \\
\text { Lat }\end{array}$ & edI & Lat & $\begin{array}{l}\mathrm{Pa} \\
\text { Long }\end{array}$ & $\begin{array}{l}\text { leopole } \\
\text { a95, dp }\end{array}$ & $\mathrm{a} 95, \mathrm{dm}$ & Reference & Grade \\
\hline $\begin{array}{l}\mathrm{KT} \text {, Khetachan terrane, } \\
\text { Kolyma-Omolon } \\
\text { superterrane. } \\
\text { Russian Northeast. }\end{array}$ & Unnamed unit. & 67 & 163.5 & $\begin{array}{l}\text { Creta- } \\
\text { ceous }\end{array}$ & 69 & 42 & 76.2 & 90.0 & 58 & 140 & 43.1 & 42.1 & $\begin{array}{l}\text { Perchersky, } \\
1973 .\end{array}$ & $\mathrm{C}$ \\
\hline $\begin{array}{l}\text { KY, Koyukuk terrane. } \\
\text { West-Central Alaska. }\end{array}$ & Unnamed unit. & 66 & 206 & $\begin{array}{l}\text { Early } \\
\text { Creta- } \\
\text { ceous }\end{array}$ & 147 & 60.2 & 68.8 & 78.1 & 60 & 159 & 9.5 & 9 & $\begin{array}{l}\text { Hillhouse and } \\
\text { Gromme, } 1988 .\end{array}$ & A \\
\hline Same. & $\begin{array}{l}\text { Cretaceous } \\
\text { sedimentary } \\
\text { rocks. }\end{array}$ & 65 & 205 & $\begin{array}{l}\text { Mid- } \\
\text { Creta- } \\
\text { ceous }\end{array}$ & 139 & 55.4 & 61.8 & 68.8 & 77 & 112 & 6 & NA & $\begin{array}{l}\text { Harris, 1985; } \\
\text { Harris and } \\
\text { others, } 1986 .\end{array}$ & A \\
\hline $\begin{array}{l}\text { Same. } \\
\text { Nulato quadrangle, West- } \\
\text { Central Alaska. }\end{array}$ & $\begin{array}{l}\text { Fluvial-deltaic } \\
\text { sedimentary } \\
\text { rocks. }\end{array}$ & 64.4 & 202 & $\begin{array}{l}\text { Mid- } \\
\text { Creta- } \\
\text { ceous }\end{array}$ & 116 & 58.6 & 67.0 & 76.2 & 84 & 141 & 9.4 & 9 & Harris, 1985. & A \\
\hline $\begin{array}{l}\text { MAI, Mainitskiy terrane. } \\
\text { Russian Northeast. }\end{array}$ & Unnamed unit. & 63.2 & 175.3 & $\begin{array}{c}\text { Late } \\
\text { Jurassic to } \\
\text { Early } \\
\text { Creta- } \\
\text { ceous }\end{array}$ & 5 & 21 & 31.7 & 47.0 & 6.7 & 153.5 & 6.2 & 29 & $\begin{array}{l}\text { Didenko and } \\
\text { others, } 1993 .\end{array}$ & $\mathrm{A}$ \\
\hline $\begin{array}{l}\text { MT, Methow terrane. } \\
\text { Mt. Tatlow, area, Southern } \\
\text { Canadian Cordilllera. }\end{array}$ & $\begin{array}{l}\text { Powell Creek } \\
\text { Volcanics and } \\
\text { Silverquick } \\
\text { Formation. }\end{array}$ & 51.3 & 123.8 & 85 & NA & 31.9 & 37.4 & 43.7 & 356 & 26.3 & $\mathrm{NA}$ & NA & $\begin{array}{l}\text { Wynne and } \\
\text { others, } 1995 .\end{array}$ & $A$ \\
\hline $\begin{array}{l}\text { NE, Nemuro terrane. } \\
\text { Shikotan Island, Southern } \\
\text { Kuril Islands. }\end{array}$ & Kuril Formation. & 43.8 & 146.8 & $\begin{array}{l}\text { Creta- } \\
\text { ceous/Pal- } \\
\text { eocene }\end{array}$ & 53 & 33 & 36.5 & 40.0 & 69 & 46 & 4.6 & 3.3 & $\begin{array}{l}\text { Bazhenov and } \\
\text { Burtman, } 1996 .\end{array}$ & $A$ \\
\hline $\begin{array}{l}\text { Same. } \\
\text { Shikotan Island, Southern } \\
\text { Kuril Islands. }\end{array}$ & Shikotan Island. & 43.9 & 147 & $\begin{array}{l}\text { Creta- } \\
\text { ceous }\end{array}$ & 5 & 13 & 28.2 & 53.9 & 50 & 48 & 30 & 19 & $\begin{array}{l}\text { Bazhenov and } \\
\text { Burtman, } 1996 .\end{array}$ & A \\
\hline Same. & Nemuro Peninsula. & 43 & 146 & $\begin{array}{l}\text { Crcta- } \\
\text { ceous }\end{array}$ & 35 & 31.1 & 36.5 & 42.9 & 74 & 37 & 6 & 9 & Fujiwara, 1974. & $\mathrm{~B}$ \\
\hline $\begin{array}{l}\text { NSV, North Asian Craton } \\
\text { Margin, Verkhoyansk } \\
\text { fold belt, West } \\
\text { Verkhoyansk area }\end{array}$ & Bedidzhan Group. & 64 & 130 & $\begin{array}{l}\text { Middle \& } \\
\text { Upper } \\
\text { Triassic }\end{array}$ & 64 & 40 & 57.0 & 80.1 & 35 & 152 & 22.9 & 20.2 & Slautsitais, 1971. & $\mathrm{C}$ \\
\hline Same. & $\begin{array}{l}\text { Tagandzhinsk \& } \\
\text { Up Keltersk } \\
\text { Groups. }\end{array}$ & 65.5 & 128 & $\begin{array}{l}\text { Early } \\
\text { Triassic }\end{array}$ & 82 & 52 & 78.1 & 90.0 & 60 & 151 & 29.5 & 29 & Slautsitais, 1971. & $\mathrm{C}$ \\
\hline
\end{tabular}


Table 3. Paleomagnetic data for geologic units and geographic areas in the Russian Far East, Alaska, and the Canadian Cordillera—Continued.

\begin{tabular}{|c|c|c|c|c|c|c|c|c|c|c|c|c|c|c|}
\hline \multicolumn{15}{|c|}{ PRE-ACCRETIONARY UNITS IN TERRANES IN RUSSIAN FAR EAST, ALASKA, AND CANADIAN CORDILLERA--Continued } \\
\hline $\begin{array}{l}\text { NX, Nixon Fork terrane. } \\
\text { Medfra Quadrangle, West- } \\
\text { Central Alaska. }\end{array}$ & $\begin{array}{l}\text { Telsitna } \\
\text { Formation. }\end{array}$ & 63.9 & 205.5 & $\begin{array}{l}\text { Middle \& } \\
\text { Late } \\
\text { Ordo- } \\
\text { vician }\end{array}$ & 14 & 16.7 & 22.8 & 29.9 & 46 & 65 & 10 & $\overline{\mathrm{NA}}$ & Plumley, 1984. & $\mathrm{~A}$ \\
\hline $\begin{array}{l}\text { NX, Nixon Fork terrane. } \\
\text { West-Central Alaska. }\end{array}$ & $\begin{array}{l}\text { Novi Mt. } \\
\text { Formation. }\end{array}$ & 63.9 & 205.5 & $\begin{array}{l}\text { Early } \\
\text { Ordo- } \\
\text { vician }\end{array}$ & 19 & 31.7 & 36.5 & 42.1 & 60 & 63 & 7 & NA & Plumley, 1984. & A \\
\hline $\begin{array}{l}\text { OKA, Olyutorka- } \\
\text { Kamchatka terrane. } \\
\text { Russian Northeast. }\end{array}$ & $\begin{array}{l}\text { Koryakia } \\
\text { sediments. }\end{array}$ & 61 & 170.5 & $\begin{array}{c}\text { Creta- } \\
\text { ceous- } \\
\text { Paleocene }\end{array}$ & 15 & 41 & 55.4 & 74.3 & 69.1 & 82.7 & 19.2 & 16.7 & $\begin{array}{l}\text { Savostin and } \\
\text { Kheyfets, } 1989 .\end{array}$ & B \\
\hline Same. & Unnamed unit. & 60.8 & 171.6 & $\begin{array}{l}\text { Latest } \\
\text { Creta- } \\
\text { ceous }\end{array}$ & 16 & 36.7 & 49.0 & 65.0 & 73 & 47 & 17 & 14 & $\begin{array}{l}\text { Heiphitz and } \\
\text { others, 1994a, b. }\end{array}$ & $\mathrm{C}$ \\
\hline Same. & Unnamed unit. & 61.5 & 170.5 & $\begin{array}{l}\text { Late } \\
\text { Creta- } \\
\text { ceous }\end{array}$ & 15 & 41 & 55.1 & 73.5 & 69 & 80 & 19 & 16 & $\begin{array}{l}\text { Heiphitz and } \\
\text { others, 1994a, b. }\end{array}$ & A \\
\hline Same. & Unnamed unit. & 61 & 171 & $\begin{array}{l}\text { Early } \\
\text { Creta- } \\
\text { ceous }\end{array}$ & NA & -73.5 & 55.1 & 73.5 & 69.1 & 82.2 & 18.8 & 16.3 & Kovalenko, 1992. & B \\
\hline Same. & Govena zone. & 60.9 & 168.2 & Eocene & 63 & 53.9 & 60.2 & 67.0 & 84 & 76 & 7 & 7 & Kovalenko, 1996. & A \\
\hline Same. & Tavlovka River. & 61.5 & 165.4 & $\begin{array}{l}\text { Late } \\
\text { Creta- } \\
\text { ceous }\end{array}$ & 5 & 75.4 & 81.3 & 87.2 & 58 & 259 & 16.6 & 21.7 & $\begin{array}{l}\text { Alexsyutin and } \\
\text { Shipunov, } 1997 .\end{array}$ & $\mathrm{C}$ \\
\hline $\begin{array}{l}\text { OL, Oloy terrane, Kolyma- } \\
\text { Omolon superterrane. } \\
\text { Russian Northeast. }\end{array}$ & Unnamed unit. & 65 & 166 & $\begin{array}{l}\text { Early } \\
\text { Creta- } \\
\text { ceous }\end{array}$ & 110 & 80 & 88.0 & 90.0 & 67 & 168 & 8 & 8 & Pechersky, 1970. & $\mathrm{C}$ \\
\hline $\begin{array}{l}\text { OM, Omolon terrane, } \\
\text { Kolyma-Omolon } \\
\text { superterrane. } \\
\text { Russian Northeast. }\end{array}$ & Unnamed unit. & 63 & 159.5 & $\begin{array}{l}\text { Late } \\
\text { Creta- } \\
\text { ceous }\end{array}$ & 4 & 54 & 76.2 & 90.0 & 50 & 171 & 25.4 & 24.9 & Pechersky, 1970. & $\mathrm{C}$ \\
\hline
\end{tabular}


Table 3. Paleomagnetic data for geologic units and geographic areas in the Russian Far East, Alaska, and the Canadian Cordillera—Continued.

\begin{tabular}{|c|c|c|c|c|c|c|c|c|c|c|c|c|c|c|}
\hline \multicolumn{15}{|c|}{ PRE-ACCRETIONARY UNITS IN TERRANES IN RUSSIAN FAR EAST, ALASKA, AND CANADIAN CORDILLERA--Continued } \\
\hline $\begin{array}{l}\text { Map Unit, Overlap } \\
\text { Assemblage. } \\
\text { Geographic Area. }\end{array}$ & Rock Unit & Lat & Long & Age & $\begin{array}{l}\text { No. of } \\
\text { Sites }\end{array}$ & $-\mathrm{dl}$ & $\begin{array}{l}\text { Lolatitu } \\
\text { Lat }\end{array}$ & $+\mathrm{dl}$ & Lat & ${ }_{\text {Long }} \mathbf{P}$ & $\begin{array}{l}\text { leopole } \\
\text { a95, dp }\end{array}$ & a95, dm & Reference & Grade \\
\hline Same. & Unnamed unit. & 65 & 159 & $\begin{array}{c}\text { Late } \\
\text { Triassic }\end{array}$ & 153 & 35 & 42.1 & 51.1 & 61 & 284 & 10.7 & 8.2 & Khramov, 1979. & $\mathrm{C}$ \\
\hline Same. & Unnamed unit. & 63 & 159 & Triassic & 35 & 35 & 48.3 & 67.0 & 56 & 248 & 19.6 & 16 & $\begin{array}{l}\text { Perchersky, } \\
1973 .\end{array}$ & $\mathrm{C}$ \\
\hline Same. & Vodopadnyi Creek. & 65 & 156 & Permian & 28 & 44.0 & 54.0 & 65.0 & 73 & 270 & 7 & NA & $\begin{array}{l}\text { Kashik and } \\
\text { others, } 1990 .\end{array}$ & $\mathrm{A}$ \\
\hline Same. & Unnamed unit. & 65 & 162 & $\begin{array}{c}\text { Late } \\
\text { Devonian }\end{array}$ & 20 & 27 & 35.5 & 45.7 & 23 & 219 & 12.8 & 9.1 & $\begin{array}{l}\text { Kolosev, } \\
1981\end{array}$ & $\mathrm{~A}$ \\
\hline $\begin{array}{l}\text { OV, Omulevka terrane, } \\
\text { Kolyma-Omolon } \\
\text { superterrane. }\end{array}$ & $\begin{array}{l}\text { Jugo-Suordakh- } \\
\text { skaya St. }\end{array}$ & 67.5 & 139.4 & $\begin{array}{c}\text { Late } \\
\text { Jurassic }\end{array}$ & 51 & 32 & 68.8 & 90.0 & 88 & 99 & 53.2 & 50.5 & $\begin{array}{c}\text { Neustroev and } \\
\text { others, } 1993 .\end{array}$ & A \\
\hline $\begin{array}{l}\text { Russian Northeast. } \\
\text { PW, Prince William terrane. } \\
\text { Southern Alaska. }\end{array}$ & Ophiolite. & 60.9 & 210.7 & 57 & 8 & 46.6 & 58.6 & 73.0 & 37 & 167 & 11 & NA & $\begin{array}{l}\text { Bol and others, } \\
1992 .\end{array}$ & A \\
\hline Same. & $\begin{array}{c}\text { Ghost Rocks } \\
\text { Formation. }\end{array}$ & 57.3 & 207.7 & Paleocene & 11 & 25.8 & 33.6 & 43.2 & 55 & 93 & 12 & 8 & $\begin{array}{l}\text { Plumley and } \\
\text { others, } 1983 .\end{array}$ & A \\
\hline Same. & Same. & 56.9 & 206.1 & Paleocene & 16 & 37.6 & 47.0 & 58.6 & 43 & 269 & 11 & NA & $\begin{array}{l}\text { Plumley and } \\
\text { others, } 1983 .\end{array}$ & A \\
\hline Same.. & Orca Group & 60.4 & 212.4 & $\begin{array}{l}\text { Paleocene } \\
\text { to Eocene }\end{array}$ & 9 & NA & 47 & NA & 56 & 236 & 21 & NA & $\begin{array}{l}\text { Hillhouse and } \\
\text { Gromme } 1977 .\end{array}$ & A \\
\hline $\begin{array}{l}\text { Same. } \\
\text { Glacier Island, Southern } \\
\quad \text { Alaska. }\end{array}$ & Same. & 60.8 & 212.8 & $\begin{array}{l}\text { Paleocene } \\
\text { to Eocene }\end{array}$ & 14 & 25.8 & 37.6 & 53.9 & 72 & 185 & 11.0 & NA & Bol, 1993 & B \\
\hline $\begin{array}{l}\text { QN, Quesnellia terrane, } \\
\text { Southern Canadian } \\
\text { Cordilllera }\end{array}$ & Nicola Volcanics. & 48.9 & 239.4 & $\begin{array}{l}\text { Middle } \\
\text { Triassic }\end{array}$ & 26 & 23.5 & 28.2 & 33.6 & 53 & 349 & 7 & 5 & Symons, $1985 \mathrm{~b}$. & $\mathrm{C}$ \\
\hline Same. & Copper Mountain. & 49.3 & 239.5 & Jurassic & 11 & 20.6 & 23.5 & 26.6 & 57 & 12 & 4 & 3 & $\begin{array}{l}\text { Symons and } \\
\text { Litalien, } 1984 .\end{array}$ & $\mathrm{C}$ \\
\hline Same. & Tulameen. & 49.5 & 239 & $\begin{array}{l}\text { Early } \\
\text { Jurassic }\end{array}$ & 10 & 8.7 & 18.6 & 31.7 & 46 & 119 & 20 & 11 & $\begin{array}{l}\text { Hicken and } \\
\text { Irving, } 1977 .\end{array}$ & $\mathrm{C}$ \\
\hline Same. & Guichon batholith. & 50.5 & 239 & $\begin{array}{c}\text { Late } \\
\text { Triassic }\end{array}$ & 49 & 15.5 & 20.0 & 25.0 & 52 & 12 & 8 & 5 & $\begin{array}{l}\text { Symons, 1971, } \\
\text { 1983b. }\end{array}$ & $\mathrm{C}$ \\
\hline Same. & $\begin{array}{l}\text { Dzhabuldinginskay } \\
\text { a St. }\end{array}$ & 67.5 & 139.4 & $\begin{array}{l}\text { Middle } \\
\text { Jurassic }\end{array}$ & 33 & 51 & 61.8 & 74.3 & 45 & 106 & 12.8 & 11.7 & $\begin{array}{c}\text { Neustroev and } \\
\text { others, } 1993 .\end{array}$ & A \\
\hline $\begin{array}{l}\text { RA, Rassokha terrane } \\
\text { Kolyma-Omolon } \\
\text { superterrane. } \\
\text { Russian Northeast. }\end{array}$ & $\begin{array}{l}\text { Magar and } \\
\text { Uvyazkin Group. }\end{array}$ & 65 & 149 & $\begin{array}{c}\text { Late } \\
\text { Devonian } \\
\& \text { Early } \\
\text { Carboni- } \\
\text { ferous }\end{array}$ & 78 & -15 & 12.0 & 14.9 & 36 & 310 & 5.3 & 2.8 & Iosifidi, 1989. & B \\
\hline
\end{tabular}


Table 3. Paleomagnetic data for geologic units and geographic areas in the Russian Far East, Alaska, and the Canadian Cordillera-Continued.

\begin{tabular}{|c|c|c|c|c|c|c|c|c|c|c|c|c|c|c|}
\hline \multicolumn{15}{|c|}{ PRE-ACCRETIONARY UNITS IN TERRANES IN RUSSIAN FAR EAST, ALASKA, AND CANADIAN CORDILLERA--Continued } \\
\hline $\begin{array}{l}\text { Map Unit, Overlap } \\
\text { Assemblage. } \\
\text { Geographic Area. }\end{array}$ & Rock Unit & Lat & Long & Age & $\begin{array}{l}\text { No. of } \\
\text { Sites }\end{array}$ & ${ }_{-d l} \bar{P}$ & $\begin{array}{l}\text { eolatit } \\
\text { Lat }\end{array}$ & $+\mathrm{dI}$ & Lat & Long & $\begin{array}{l}\text { eopole } \\
\text { a95, dp }\end{array}$ & a95, dm & Reference & Grade \\
\hline $\begin{array}{l}\text { SM, Slide Mountain } \\
\text { terrane. } \\
\text { British Columbia. }\end{array}$ & $\begin{array}{l}\text { Sylvester } \\
\text { allochton. }\end{array}$ & 59 & 231.3 & $\begin{array}{l}\text { Pennsyl- } \\
\text { vanian to } \\
\text { Permian }\end{array}$ & 12 & 5.4 & 8.5 & 11.8 & NA & $\mathrm{NA}$ & $\mathrm{NA}$ & $\overline{\mathrm{NA}}$ & $\begin{array}{l}\text { Butler and others, } \\
\text { 1988; Richards } \\
\text { and others, } \\
1993 .\end{array}$ & $\bar{A}$ \\
\hline Same. & Sliding Mountain. & 53.15 & 238.5 & $\begin{array}{l}\text { Pennsyl- } \\
\text { vanian } \\
\text { Permian }\end{array}$ & 28 & -0.7 & 1.9 & 4.5 & 15.1 & 36.2 & 6 & 3 & $\begin{array}{l}\text { Butler and others, } \\
\text { 1988; Richards } \\
\text { and others, } \\
1993 .\end{array}$ & A \\
\hline $\begin{array}{l}\text { ST, Stikinia terrane. } \\
\text { British Columbia. }\end{array}$ & $\begin{array}{l}\text { Silverquick \& } \\
\text { Powell Creeks. }\end{array}$ & 51.3 & 236.2 & $\begin{array}{l}\text { Mid- } \\
\text { Creta- } \\
\text { ceous }\end{array}$ & 21 & 31.9 & 37.6 & 43.2 & 356 & 26 & NA & NA & $\begin{array}{l}\text { Wynne and } \\
\text { others, 1993; } \\
\text { Maxson and } \\
\text { others, } 1993 \text {. }\end{array}$ & B \\
\hline Same. & Topley Intrusives. & 54 & 235 & Jurassic & 8 & 20.6 & 30.8 & 44.5 & 56 & 119 & 17 & 11 & $\begin{array}{l}\text { Monger and } \\
\text { Irving, 1980; } \\
\text { Symons, 1983a. }\end{array}$ & $\mathrm{C}$ \\
\hline Same: & Telkwa Formation. & 54.8 & 231.9 & $\begin{array}{c}\text { Early } \\
\text { Jurassic }\end{array}$ & 9 & 26.8 & 36.5 & 49.3 & 27 & 169 & 15 & 11 & $\begin{array}{l}\text { Vandall and } \\
\text { Palmer, } 1990 .\end{array}$ & B \\
\hline Same. & Telkwa Formation. & 54.4 & 231.9 & $\begin{array}{c}\text { Early } \\
\text { Jurassic }\end{array}$ & 10 & 24.2 & 30.8 & 38.7 & -11 & 193 & 11 & 7 & $\begin{array}{l}\text { Vandall and } \\
\text { Palmer, } 1990 .\end{array}$ & A \\
\hline Same. & Telkwa Formation. & 54.5 & 232.9 & $\begin{array}{l}\text { Early } \\
\text { Jurassic }\end{array}$ & 8 & 22.3 & 28.2 & 35.2 & 54 & 109.9 & 10 & 6 & $\begin{array}{l}\text { Vandall and } \\
\text { Palmer, } 1990 .\end{array}$ & B \\
\hline Same. & $\begin{array}{l}\text { Nilkitkwa } \\
\text { Formation. }\end{array}$ & 55.6 & 233.6 & 190 & 37 & 22.0 & 35.5 & 55.4 & 70 & 57 & 23 & 16 & $\begin{array}{l}\text { Monger and } \\
\text { Irving, } 1980 .\end{array}$ & $\mathrm{C}$ \\
\hline Same. & Telkwa Formation. & 55.8 & 233.4 & 200 & 28 & 21.3 & 36.5 & 60.2 & 17 & 185 & 26 & 19 & $\begin{array}{l}\text { Monger and } \\
\text { Irving, } 1980 .\end{array}$ & $\mathrm{C}$ \\
\hline Same. & Telkwa Formation. & 56.5 & 233.2 & 200 & 20 & 14.3 & 32.6 & 65.2 & 40 & 144 & 34 & 23 & $\begin{array}{l}\text { Monger and } \\
\text { Irving, } 1980 .\end{array}$ & $\mathrm{C}$ \\
\hline Same. & Telkwa Formation. & 54.8 & 231.9 & $\begin{array}{c}\text { Early } \\
\text { Jurassic }\end{array}$ & 9 & 26.8 & 36.5 & 49.3 & 27 & 169 & 15 & 11 & $\begin{array}{l}\text { Vandall and } \\
\text { Palmer, } 1990 .\end{array}$ & B \\
\hline Same. & Telkwa Formation. & 54.4 & 231.9 & $\begin{array}{l}\text { Early } \\
\text { Jurassic }\end{array}$ & 10 & 24.2 & 30.8 & 38.7 & -11 & 193 & 11 & 7 & $\begin{array}{l}\text { Vandall and } \\
\text { Palmer, } 1990 .\end{array}$ & A \\
\hline Same. & Telkwa Formation. & 54.5 & 232.9 & $\begin{array}{c}\text { Early } \\
\text { Jurassic }\end{array}$ & 8 & 22.3 & 28.2 & 35.2 & 54 & 109.9 & 10 & 6 & $\begin{array}{l}\text { Vandall and } \\
\text { Palmer, } 1990\end{array}$ & B \\
\hline Same. & Asitka Group & 56.7 & 233.4 & $\begin{array}{c}\text { Late } \\
\text { Permian }\end{array}$ & & 17.4 & 22.8 & 29.0 & 40 & 123 & 5 & & $\begin{array}{l}\text { Irving and } \\
\text { Monger, } 1987\end{array}$ & A \\
\hline $\begin{array}{l}\text { TL, Talovskiy terrane. } \\
\text { Penzhino Gulf, Russian } \\
\text { Northeast. }\end{array}$ & Unnamed unit. & 61.5 & 164 & $\begin{array}{l}\text { Early } \\
\text { Creta- } \\
\text { ceous }\end{array}$ & 10 & 40.9 & 61.8 & 90.0 & 61 & 225 & 27.4 & 25 & $\begin{array}{l}\text { Perchersky, } \\
1970 .\end{array}$ & $\mathrm{C}$ \\
\hline
\end{tabular}


Table 3. Paleomagnetic data for geologic units and geographic areas in the Russian Far East, Alaska, and the Canadian Cordillera-Continued.

\begin{tabular}{|c|c|c|c|c|c|c|c|c|c|c|c|c|c|c|}
\hline \multicolumn{15}{|c|}{ PRE-ACCRETIONARY UNITS IN TERRANES IN RUSSIAN FAR EAST, ALASKA, AND CANADIAN CORDILLERA--Continued } \\
\hline $\begin{array}{l}\text { Map Unit, Overlap } \\
\text { Assemblage. } \\
\text { Geographic Area. }\end{array}$ & Rock Unit & Lat & Long & Age & $\begin{array}{l}\text { No. of } \\
\text { Sites }\end{array}$ & $-d \mathbf{F}$ & $\begin{array}{l}\text { eolatitu } \\
\text { Lat }\end{array}$ & le dl & Lat & $\begin{array}{l}\mathrm{Pa} \\
\text { Long }\end{array}$ & $\begin{array}{l}\text { eopole } \\
\text { a95, dp }\end{array}$ & a95, dm & Reference & Grade \\
\hline Same. & Unnamed unit. & 61.5 & 164.5 & $\begin{array}{l}\text { Triassic- } \\
\text { Jurassic }\end{array}$ & & 14 & 19 & 25 & $\overline{43}$ & 304 & 9.5 & 5.5 & $\begin{array}{l}\text { Heiphitz and } \\
\text { others, } 1994 .\end{array}$ & $\bar{B}$ \\
\hline $\begin{array}{l}\text { VL, Viliga terrane. } \\
\text { Russian Northeast. }\end{array}$ & Unnamed unit. & 62 & 156 & $\begin{array}{l}\text { Middle } \\
\text { Jurassic }\end{array}$ & 93 & 47.0 & 65.2 & 88.0 & 42 & 130 & 22.4 & 20.8 & Pechersky, 1970. & B \\
\hline $\begin{array}{l}\text { VT, Vetlovskiy terrane. } \\
\text { Kamchatka Peninsula. }\end{array}$ & $\begin{array}{l}\text { Kapitskaya } \\
\text { Formation. }\end{array}$ & 56.4 & 162.1 & $\begin{array}{l}\text { Late } \\
\text { Creta- } \\
\text { ceous }\end{array}$ & 4 & 27.9 & 41.8 & 61.8 & 84 & 76 & 6.5 & 7.2 & $\begin{array}{l}\text { Pechersky and } \\
\text { Shapiro, } 1996 .\end{array}$ & A \\
\hline $\begin{array}{l}\text { WSA, West Sakhalin } \\
\text { terrane. } \\
\text { Sakhalin Island, Russian } \\
\text { Southeast. }\end{array}$ & Unnamed unit. & 47.3 & 142.4 & $\begin{array}{l}\text { Late } \\
\text { Creta- } \\
\text { ceous }\end{array}$ & 6 & 34.5 & 40.9 & 48.3 & 73 & 246 & 9 & 7 & Pechersky, 1970. & $\mathrm{C}$ \\
\hline $\begin{array}{l}\text { Same. } \\
\text { Primorye, Russian } \\
\text { Southeast. }\end{array}$ & Unnamed unit. & 46.5 & 138.5 & $\begin{array}{l}\text { Late } \\
\text { Creta- } \\
\text { ceous }\end{array}$ & 5 & 27.4 & 36.5 & 48.3 & 68 & 245 & 14 & 10 & $\begin{array}{l}\text { Nevolina and } \\
\text { Sokarev, } 1986 .\end{array}$ & $\mathrm{C}$ \\
\hline Same. & Unnamed unit. & 46.5 & 138.5 & $\begin{array}{l}\text { Late } \\
\text { Creta- } \\
\text { ceous }\end{array}$ & 4 & 32.6 & 43.2 & 57.0 & 83 & 20 & 12 & -8 & $\begin{array}{l}\text { Nevolina and } \\
\text { Sokarev, } 1986 .\end{array}$ & $\mathrm{C}$ \\
\hline \multicolumn{15}{|c|}{ PRE-ACCRETIONARY UNITS IN WRANGELLIA SUPERTERRANE (WR) IN ALASKA, AND CANADIAN CORDILLERA } \\
\hline $\begin{array}{l}\text { AX, Alexander Sequence. } \\
\text { Keku Strait, Southeastern } \\
\text { Alaska. }\end{array}$ & $\begin{array}{l}\text { Hound Island } \\
\text { Volcanics.. }\end{array}$ & 56.9 & 226.2 & Triassic & 18 & 6.8 & 16.7 & 29.5 & -0.3 & 283.9 & 19.6 & 10.9 & $\begin{array}{c}\text { Haeussler and } \\
\text { others, } 1992 .\end{array}$ & A \\
\hline $\begin{array}{l}\text { Same. } \\
\text { Prince of Wales Island, } \\
\text { Southeastern Alaska. }\end{array}$ & $\begin{array}{l}\text { Landrones \& } \\
\text { Klawak } \\
\text { Formations. }\end{array}$ & 55.5 & 227 & $\begin{array}{l}\text { Pennsyl- } \\
\text { vanian }\end{array}$ & 33 & 1.5 & 7.6 & 14.3 & 12 & 133 & 12 & 6 & $\begin{array}{c}\text { Van der Voo and } \\
\text { others, } 1980 .\end{array}$ & A \\
\hline $\begin{array}{l}\text { Same. } \\
\text { Ketchikan quadrangle, } \\
\text { Southeastern Alaska. }\end{array}$ & $\begin{array}{l}\text { Peratrovich } \\
\text { Formation. }\end{array}$ & 55.5 & 227 & $\begin{array}{l}\text { Mississip- } \\
\text { pian }\end{array}$ & 28 & 7.1 & 14.3 & 22.8 & 14 & 141 & 14 & 8 & $\begin{array}{c}\text { Van der Voo and } \\
\text { others, } 1980 .\end{array}$ & A \\
\hline $\begin{array}{l}\text { Same. } \\
\text { Kuiu Island, Southeastern } \\
\text { Alaska. }\end{array}$ & $\begin{array}{l}\text { Karheen } \\
\text { Formation. }\end{array}$ & 56.9 & 225.8 & $\begin{array}{c}\text { Early } \\
\text { Devonian }\end{array}$ & 25 & NA & 13.5 & NA & -11 & 154 & NA & NA & $\begin{array}{l}\text { Gromme and } \\
\text { Hillhouse, } \\
1997 .\end{array}$ & $\mathrm{B}$ \\
\hline $\begin{array}{l}\text { PE, Peninsular sequence. } \\
\text { Wrangellia superterrane, } \\
\text { Alaska Peninsula. }\end{array}$ & $\begin{array}{l}\text { Chignik \& Hoodoo } \\
\text { Formations. }\end{array}$ & 56 & 200 & $\begin{array}{l}\text { Late } \\
\text { Creta- } \\
\text { ceous }\end{array}$ & 47 & 18.0 & 25.0 & 33.6 & 40 & 96 & 12 & 8 & $\begin{array}{l}\text { Stone and } \\
\text { Packer, } 1979 .\end{array}$ & B \\
\hline Same. & $\begin{array}{l}\text { Chignik } \\
\text { Formation. }\end{array}$ & 56 & 200 & $\begin{array}{l}\text { Late } \\
\text { Creta- } \\
\text { ceous }\end{array}$ & 24 & NA & NA & NA & 39 & 343 & 11 & NA & $\begin{array}{l}\text { Stone and } \\
\text { Packer, } 1979 .\end{array}$ & $\mathrm{B}$ \\
\hline
\end{tabular}




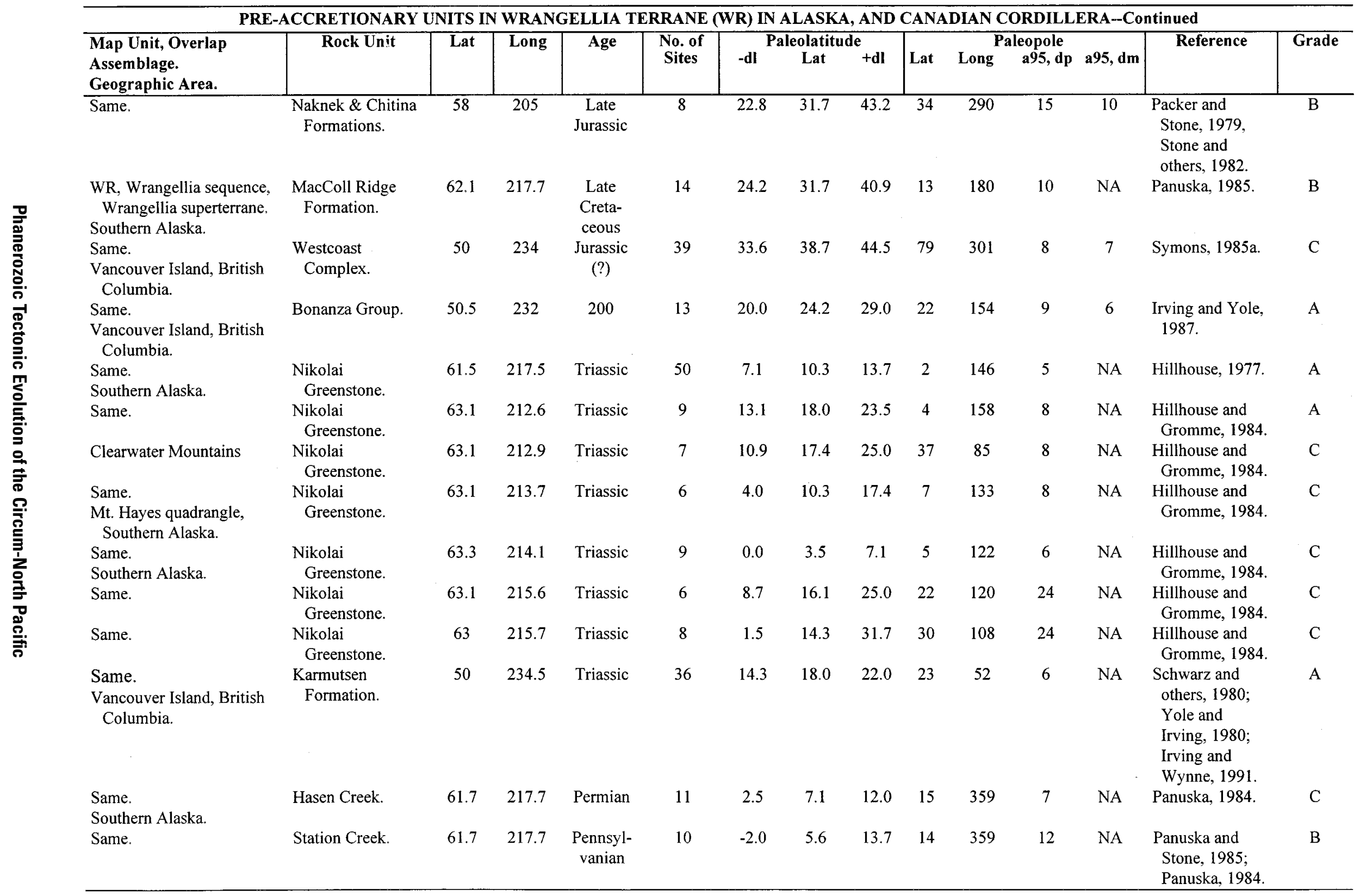




\section{Selected Series of U.S. Geological Survey Publications}

\section{Books and Other Publications}

Professional Papers report scientific data and interpretations of lasting scientific interest that cover all facets of USGS investigations and research.

Bulletins contain significant data and interpretations that are of lasting scientific interest but are generally more limited in scope or geographic coverage than Professional Papers.

Water-Supply Papers are comprehensive reports that present significant interpretive results of hydrologic investigations of wide interest to professional geologists, hydrologists, and engineers. The series covers investigations in all phases of hydrology, including hydrogeology, availability of water, quality of water, and use of water.

Circulars are reports of programmatic or scientific information of an ephemeral nature; many present important scientific information of wide popular interest. Circulars are distributed at no cost to the public.

Fact Sheets communicate a wide variety of timely information on USGS programs, projects, and research. They commonly address issues of public interest. Fact Sheets generally are two or four pages long and are distributed at no cost to the public.

Reports in the Digital Data Series (DDS) distribute large amounts of data through digital media, including compact discread-only memory (CD-ROM). They are high-quality, interpretive publications designed as self-contained packages for viewing and interpreting data and typically contain data sets, software to view the data, and explanatory text.

Water-Resources Investigations Reports are papers of an interpretive nature made available to the public outside the formal USGS publications series. Copies are produced on request (unlike formal USGS publications) and are also available for public inspection at depositories indicated in USGS catalogs.

Open-File Reports can consist of basic data, preliminary reports, and a wide range of scientific documents on USGS investigations. Open-File Reports are designed for fast release and are available for public consultation at depositories.

\section{Maps}

Geologic Quadrangle Maps (GQ's) are multicolor geologic maps on topographic bases in 7.5- or 15-minute quadrangle formats (scales mainly 1:24,000 or 1:62,500) showing bedrock, surficial, or engineering geology. Maps generally include brief texts; some maps include structure and columnar sections only.

Geophysical Investigations Maps (GP's) are on topographic or planimetric bases at various scales. They show results of geophysical investigations using gravity, magnetic, seismic, or radioactivity surveys, which provide data on subsurface structures that are of economic or geologic significance.
Miscellaneous Investigations Series Maps or Geologic Investigations Series (I's) are on planimetric or topographic bases at various scales; they present a wide variety of format and subject matter. The series also incudes 7.5-minute quadrangle photogeologic maps on planimetric bases and planetary maps.

\section{Information Periodicals}

Metal Industry Indicators (MII's) is a free monthly newsletter that analyzes and forecasts the economic health of five metal industries with composite leading and coincident indexes: primary metals, steel, copper, primary and secondary aluminum, and aluminum mill products.

Mineral Industry Surveys (MIS's) are free periodic statistical and economic reports designed to provide timely statistical data on production, distribution, stocks, and consumption of significant mineral commodities. The surveys are issued monthly, quarterly, annually, or at other regular intervals, depending on the need for current data. The MIS's are published by commodity as well as by State. A series of international MIS's is also available.

Published on an annual basis, Mineral Commodity Summaries is the earliest Government publication to furnish estimates covering nonfuel mineral industry data. Data sheets contain information on the domestic industry structure, Government programs, tariffs, and 5-year salient statistics for more than 90 individual minerals and materials.

The Minerals Yearbook discusses the performance of the worldwide minerals and materials industry during a calendar year, and it provides background information to assist in interpreting that performance. The Minerals Yearbook consists of three volumes. Volume I, Metals and Minerals, contains chapters about virtually all metallic and industrial mineral commodities important to the U.S. economy. Volume II, Area Reports: Domestic, contains a chapter on the minerals industry of each of the 50 States and Puerto Rico and the Administered Islands. Volume III, Area Reports: International, is published as four separate reports. These reports collectively contain the latest available mineral data on more than 190 foreign countries and discuss the importance of minerals to the economies of these nations and the United States.

\section{Permanent Catalogs}

"Publications of the U.S. Geological Survey, 1879-1961" and "Publications of the U.S. Geological Survey, 19621970" are available in paperback book form and as a set of microfiche.

"Publications of the U.S. Geological Survey, 1971-1981" is available in paperback book form (two volumes, publications listing and index) and as a set of microfiche.

Annual supplements for 1982, 1983, 1984, 1985, 1986, and subsequent years are available in paperback book form. 
ISBN 0-607-9ь394-8

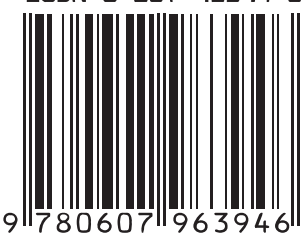

